Karla Lopez Blanco Alvarez

\title{
O projeto de espaços públicos na periferia de São Paulo: uma questão sócio-ambiental
}

Dissertação apresentada à Faculdade de Arquitetura e Urbanismo da Universidade de São Paulo para obtenção do título de mestre em arquitetura Área de Concentração: Paisagem e Ambiente

Orientador: Prof. Dr. Eugênio Fernandes Queiroga 
AUTORIZO A REPRODUÇÃO E DIVULGAÇÃO TOTAL OU PARCIAL DESTE TRABALHO, POR QUALQUER MEIO CONVENCIONAL OU ELETRÔNICO, PARA FINS DE ESTUDO E PESQUISA, DESDE QUE CITADA A FONTE.

ASSINATURA:

E-MAIL:

Alvarez, Karla Lopez Blanco

A473p O projeto de espaços públicos na periferia de São Paulo: uma questão sócio-ambiental / Karla Lopez Blanco Alvarez. - - São Paulo, 2008.

219 p. : il.

Dissertação (Mestrado - Área de Concentração: Paisagem e Ambiente) - FAUUSP.

Orientador: Eugenio Fernandes Queiroga.

1.Espaço público - São Paulo (SP) 2.Espaços livres - São Paulo (SP) 3.Praças - São Paulo (SP) I.Título

CDU 712.25(816.11) 
Dedico este trabalho à minha família querida; ao meu companheiro amigo; ao meu orientador, que acreditou desde o início nesta pesquisa e que tão sabiamente me conduziu ao longo deste processo, a ele o meu muito obrigada; aos amigos da família Quapá que me incenticaram desde o primeiro plano e a todos os companheiros do Programa Centros de Bairro que, apesar das críticas e adversidades, trabalharam com dedicação na esperança de construir uma cidade melhor. 
Este trabalho destina-se ao estudo dos sistemas de espaços livres, tendo como estudo de caso a cidade de São Paulo e o conjunto de intervenções urbanas realizadas na sua periferia durante a gestão da então prefeita Marta Suplicy, denominado Programa Centros de Bairro. São apresentados conceitos que nortearam o processo de pesquisa, destacando-se os de espaço, lugar, paisagem, espaços livres e sistema de espaços livres; e que são o resultado da primeira etapa de trabalhos do Projeto Temático de Pesquisa ${ }^{1}$, buscando a partir daí compreender, em linhas gerais, a configuração e formação dos Espaços Livres Públicos da cidade de São Paulo. Num segundo momento, a partir da implantação do Programa Centros de Bairro, identificase nos meandros da idealização do Programa e na efetiva vivência da implantação das praças e de suas relações com os bairros, a manifestação das diversas formas de apropriação desses espaços e sua relação com a configuração do Sistema pública contemporânea no Brasil" - QUAPÁ - SEL de Espaços. 
This work has the purpose to study free spaces systems, having as a case of study the city of Sao Paulo and the group of urban interventions done on its suburb during the mandate of the Mayor Marta Suplicy at the time, called "Centros de Bairro". Concepts are presented, that oriented the research process, placing in evidence the ones of space, place, landscape, free spaces and system of free spaces; that are the result of the first part of works of the thematic projet of research QUAPA-SEL, looking forward to comphehend, in general, the configuration and formation of Public Free Spaces of the city of Sao Paulo. As a second step, after the implantation of the "Centros de Bairro", Its seen in the details of the idea of the program and in its effective experience of the implementation of squares and its relations with the neighborhoods, the manifestation of different ways of appropriation of these spaces and its relation to the configuration of the system of spaces. 


\section{Lista de Figuras}

Fig. 1 e 2. "Roman de la rose" e "Jardin del paraíso", respectivamente, ambas do século XV.

Fig. 3. Peter Brueghel, século XVI.

Fig. 4. Villa Médicis em Fiesole.

Fig. 5. Uma rua qualquer da periferia da cidade.

Fig. 6 e 7. Fotos dos atuais Campinhos de Futebol.

Fig. 8. Planta de São Paulo de Piratininga de Afonso de Freitas (1560).

Fonte: Biblioteca Mario de Andrade - Setor de Mapoteca.

Fig. 9. Planta da região central de São Paulo (1968).

Fonte: Biblioteca Mário de Andrade, Setor de Mapoteca.

Fig. 10. Planta da região central de São Paulo (1897).

Fonte: Biblioteca Mario de Andrade - Setor de Mapoteca.

Fig. 11, 12 e 13. Central Park.

Fig. 14 e 15. Plano cidade jardim de e Vista da Rua Guadelupe, entre a Rua Estados Unido e a Av. Brasil, respectivamente.

Fig. 16. Vista aérea do Jardim América.

Fig. 17 e 18. Fotos do Jardim da Luz e do boulevard da Av. Tiradentes.

Fonte: Conselho de Defesa do Patrimônio Histórico, Arqueológico, Artístico e Turístico - CONDEPHAAT - Setor de Fotografia.

Fig. 19 e 20. Fotos do Clube de Regatas Tietê.

Fonte: Conselho de Defesa do Patrimônio Histórico, Arqueológico, Artístico e Turístico - CONDEPHAAT - Setor de Fotografia.

Fig. 21, 22 e 23. Fotos do Parque Infantil Dom Pedro II (1937).

Fonte: Acervo SAN/DPH/SHC/PMSP. Foto: Benedito Junqueira Duarte.

Fig. 24. Mapa do Estado de São Paulo indicando a distribuição das Áreas de 
Proteção Ambiental.

Fonte: Secretaria do Verde e do Meio Ambiente - SEMA

Fig. 25 e 26. Mapa indicando os principais parques e reservas da cidade de São Paulo e

Quadro quantitativo das praças e canteiros, respectivamente. Dados da Secretaria Municipal do Verde e do Meio Ambiente.

Fig. 27. Mapa das áreas públicas municipais.

Fonte: Dados da Secretaria Municipal do Verde e do Meio Ambiente.

Fig. 28. Mapa do Sistema Viário Estrutural do Município.

Fonte: Secretaria Municipal do Planejamento - SEMPLA

Fig. 29. Mapa indicativo das Sub-regiões do município de São Paulo.

Fonte: PMSP - Prefeitura do Município de São Paulo.

Fig. 30. Mapa de São Paulo indicando a divisão das Subprefeituras.

Lei Municipal 13.399/02

Fonte: Secretaria Municipal de Planejamento - SEMPLA

Fig. 31. Foto aérea do Parque do Ibirapuera na Zona Sul do Município.

Fonte: Google Earth, 2002.

Fig. 32, 33 e 34. Fotos dos Parques do Horto Florestal, Villa Lobos e do Carno, respectivamente.

Fonte: Arquivo pessoal.

Fig. 35. Mapa de distribuição dos Centros Desportivos Municipais - CDM.

Fonte: Prefeitura do Município de São Paulo - PMSP.

Fig. 36. Mapa indicativo da distribuição das praças do programa pela cidade

Fig. 37 e 38. Av. Armando de Arruda Pereira - junho 2003 - e Largo do Araribá - outubro 2002, respectivamente.

Foto: Lopez

Fig. 39 e 40. Largo Campo Limpo - fevereiro 2003 - e Feirão do São Luis - junho 2002, respectivamente.

Foto: Lopez

Fig. 41 e 42. Antonio de Castro Lopes e Bassano Del Grappa, respectivamente. 
Foto: Lopez

Fig. 43 e 44. Jardim Grimaldi - junho 2003 - e Vila Industrial - junho 2003. Foto: Lopez

Fig. 45 e 46. Largo de São Mateus - junho 2003 - e Praça Sampaio Vidal - junho 2003.

Foto: Lopez

Fig. 47 e 48. Praça Santíssima Trindade e Av. dos Metalúrgicos - junho 2003. Foto: Lopez

Fig. 49 e 50. Largo do Japonês - junho 2003 - e Praça Joaquim Lopes - julho 2003.

Foto: Lopez

Fig. 51 e 52. Praça Gal. Milton Tavares e Jardim Vista Alegre.

Foto: Lopez

Fig. 53 e 54. City Jaraguá e Praça João Boldo.

Foto: Lopez

Fig. 55 e 56. EMEF Remo e João XXXIII

Foto: Lopez

Fig. 57. Resedás em flor na Praça da Rua Antonio de Castro Lopes.

Foto: Lopez

Fig. 58. Foto do Feirão de São Luis - Zona Sul - antes da intervenção.

Fonte: EMURB

Fig. 59 e 60. Fotos do Feirão de São Luis após as intervenções.

Fotos: Lopez, 2003.

Fig. 61. Foto do Largo do Rosário - Penha, Zona Leste - 2004.

Foto: Lopez

Fig. 63 e 64. Praça Gal. Milton Tavares de Souza e Praça da Rua Antonio de Castro Lopes.

Foto: Lopez

Fig. 65 e 66. Largo de São Mateus e Praça Santo Dias da Silva. 
Foto: Lopez

Fig. 67 e 68. Praça do Trabalhador e Largo do Japonês.

Foto: Lopez

Fig. 69 e 70. Largo do Araribá e Praça Santo Dias da Silva.

Foto: Lopez, 2003.

Fig. 71 e 72. Av. Armando de Arruda Pereira e Praça Pe. Damião.

Fotos: Lopez, 2003.

Fig. 73 e 74. Fotos do andamento das obras City Jaraguá Praça Wilson Moreira da Costa.

Fotos: Lopez, 2002.

Fig. 75 e 76. Largo do Campo Limpo e Praça Bassano Del Grapa.

Foto: Lopez, 2003.

Fig. 77 e 78. Praça City Jaraguá e Praça EMEF Remo.

Foto: Lopez, 2003.

Fig. 79 e 80. Planta do guia de ruas do Bororé e Foto aérea do conjunto habitacional, respectivamente.

Fig. 81. Planta geral do Conjunto Habitacional com destaque nas áreas de intervenção.

Fonte: Empresa Municipal de Urbanização - EMURB

Fig. 82, 83 e 84. Conjunto Habitacional Brigadeiro Faria - abril 2002.

Foto: Empresa Municipal de Urbanização - EMURB

Fig. 85, 86 e 87. Conjunto Habitacional Brigadeiro Faria Lima - maio 2003. Fotos: Lopez, 2003.

Fig. 88. Planta Geral da Praça do Trabalhador.

Fonte: Empresa Municipal de Urbanização - EMURB

Fig. 89. Foto antes da intervenção - fevereiro de 2002.

Foto: Meirelles, 2002.

Fig. 90. Foto depois da intervenção - setembro 2002.

Foto: Meirelles, 2002. 
Fig. 91. Planta geral da intervenção.

Fonte: Empresa Municipal de Urbanização - EMURB

Fig. 92 e 93. Fotos antes da intervenção.

Foto: EMUB, 2001.

Fig. 94 e 95. Fotos depois da intervenção.

Foto: EMUB, 2004

Fig. 96 e 97. Jacaré.

Foto: Lopez, 2003

Fig. 98 e 99. Feirão do São Luis e Cidade Tiradentes - junho 2003.

Foto: Lopez, 2003.

Fig. 100. Mapa de São Paulo indicando a divisão das Subprefeituras.

Lei Municipal 13.399/02

Fonte: Secretaria Municipal de Planejamento - SEMPLA

Fig. 101. Planta das Subprefeituras da Capela do Socorro, à esquerda, e de Parelheiros, à direita; com indicação de seus respectivos distritos.

Fonte: Prefeitura do Município de São Paulo, PMSP.

Fig. 102. Mapa indicativo das Sub-regiões do município de São Paulo. Fonte: PMSP - Prefitura do Município de São Paulo.

Fig. 103. Mapa de São Paulo indicando a divisão das Subprefeituras. Lei Municipal 13.399/02

Fonte: Secretaria Municipal de Planejamento - SEMPLA

Fig. 104 e 105. Fotos aéreas.

Fig. 106. Mapa do Zoneamento do Município.

Fonte: secretaria Municipal do Planejamento - SEMPLA

Fig. 107. Mapa da Variação da População Residente no Município.

Fonte: Secretaria Municipal do Planejamento - SEMPLA

Fig. 108. Mapa da Renda Média por Distrito.

Fonte: secretaria Municipal do Planejamento - SEMPLA

Fig. 109. Mapa da Distribuição de favelas por Administração Regional.

Fonte: secretaria Municipal do Planejamento - SEMPLA 
Fig. 110, 111 e 112. Largo do Araribá, Largo do Campo Limpo e Praça do Encontro.

Foto: Lopez, junho 2003

Fig. 113, 114 e 115. Cidade Tiradentes, Praça Antonio de Castro Lopes e Praça Bassano Del Grappa.

Foto: Lopez, junho 2003

Fig. 116. Fotomontagem da região da Capela do Socorro.

Fig. 117 e 118. Acesso principal ao conjunto do Bororé, feito pela Avenida Belmira Marin, via secundária da Av. Teotônio Vilela; e mapa do sistema viário do conjunto.

Fig. 119 a 126. Fotos das áreas livres públicas do conjunto antes das intervenções, em estado de total descaso do poder público, servindo muitas vezes como bota-fora.

Fotos: Arquivo EMURB, 2001.

Fig. 127.

Fig. 128. Foto aérea do conjunto com as praças já implantadas.

Fonte: Google Earth, 2002.

Fig. 129 a 135. Fotos do cotidiano das diferentes praças do Bororé. Foto: Lopez

Fig. 136, 137 e 138. Fotos da área da horta antes da intervenção.

Foto: Arquivo da Emurb - 2001.

Fig. 139 e 140. Fotos da área da horta depois da intervenção.

Foto: Lopes, 2003.

Fig. 141 a 147. Fotos das diferentes áreas de intervenção do conjunto Bororé, com seus usos diversos.

Fotos: Lopez, 2003.

Fig. 148 e 149. Croqui de localização da área e foto aérea da praça já implantada.

Fig. 150 a 160 . Um percurso pelos diferentes setores da praça.

Foto: Lopez, 2003. 
Fig. 161. Foto aérea do local de intervenção proposta.

Fig. 162. Croqui de localização da praça.

Fig. 163 e 164. Fotos do local antes da intervenção. Fonte: Arquivo da EMURB, 2001.

Fig. 165. Planta de Implantação da praça.

Fig. 166. Maquete eletrônica apresentada à comunidade.

Fonte: EMURB

Fig. 167 e 168. Fotos do local depois da intervenção.

Fonte: Lopez, 2003.

Fig. 169 a 174. Fotos dos diferentes usos da praça. Fotos: Lopez, 2003.

Fig. 175 e 176. Fotos da apresentação do projeto da Praça do Largo do Araribá à comunidade, que já havia sido discutido com seus representantes.

Fonte: Arquivo Emurb, 2001.

Fig. 177. Foto de arborização urbana de Buenos Aires - Argentina - com a utilização de Jacarandás Mimosos.

Fonte: Arquivo pessoal 


\section{Lista de Tabe I as}

Tab. 1. Quadro quantitativo de distribuição de parques no município. Fonte: Dados da Secretaria Municipal do Planejamento - SEMPLA

Tab. 2. Quadro quantitativo de distribuição de parques $-\mathrm{m}^{2} /$ Subprefeitura. Fonte: Dados da Secretaria Municipal do Planejamento - SEMPLA

Tab. 3. Quadro quantitativo de relação de Parques e Praças/ $\mathrm{m}^{2}$ no município.

Fonte: Dados da Secretaria Municipal do Planejamento - SEMPLA

Tab. 4. Quadro quantitativo de distribuição de praças no município. Fonte: Dados da Secretaria Municipal do Planejamento - SEMPLA

Tab. 5. Quadro quantitativo de distribuição de parques $-\mathrm{m}^{2} /$ Subprefeitura.

Fonte: Dados da Secretaria Municipal do Planejamento - SEMPLA

Tab. 6. Quadro de evolução do programa.

Fonte: Sakata, 2005.

Tab. 8. Quadro quantitativo da estimativa populacional dos distritos da região da Capela do Socorro.

Fonte: Dados da Secretaria Municipal do Planejamento - SEMPLA

Tab. 9. Dados Demográficos dos Distritos pertencentes às Subprefeituras.

Fonte: Dados da Secretaria Municipal do Planejamento - SEMPLA 


\section{INTRODUÇÃO}

\section{CONCEITOS FORMADORES}

Espaço e lugar

Paisagem

A esfera da vida pública e o cotidiano

Espaços livres públicos

O sistema de espaços livres

A escala da praça

A praça na periferia

\section{A CIDADE DE SÃO PAULO}

Um breve relato da urbanização da cidade de São Paulo

\section{A CONFORMAÇÃO DO SISTEMA DE ESPAÇOS LIVRES PÚBLICOS}

O lazer organizado na efetivação do tempo livre do trabalhador

Os espaços de convívio e lazer na cidade de São Paulo

O sistema de espaços livres de São Paulo

4 O PROGRAMA CENTROS DE BAIRRO

A proposta

A distribuição pela cidade

A elaboração dos projetos

As obras

A apropriação

A manutenção

\section{A CONTRIBUIÇÃO DO PROGRAMA CENTROS DE BAIRRO NO SISTEMA DE ESPAÇOS} LIVRES DA REGIÃO DA CAPELA DO SOCORRO

A região da Capela do Socorro

O Sistema de espaços livres na Capela do Socorro

A contribuição do Programa Centros de Bairro

As praças

A inclusão dos processos participativos

A importância da arborização do sistema viário para a formação do sistema de espaços livres

6 CONSIDERAÇÕES FINAIS

\section{REFERÊNCIAS BIBLIOGRAFICAS}


São Paulo reflete na sua paisagem suas estruturas morfológicas e sociais. Na maioria das vezes, com conflitos em andamento devido a um processo econômico que não privilegia qualquer tipo de eqüidade e no qual as desigualdades têm sido um padrão.

Além disso, desde meados do século passado, a consolidação do veículo automotor como meio de transporte, seja ele o automóvel individual, o caminhão ou o ônibus; até os dias de hoje, com a televisão ou ainda a Internet como elementos de lazer coletivo, favoreceu-se a criação de novos hábitos urbanos.

Podemos observar então, uma alteração das demandas tradicionais de equipamentos e atividades ao ar livre, expressas em novos hábitos e formas urbanas, que acabam destruindo antigos procedimentos de uso do espaço livre da cidade pela sociedade, alterando significativamente a esfera pública, no que diz respeito, também, aos espaços livres urbanos.

As demandas de uso são diferentes para cada área: praças para a convivência, recreação e atividades esportivas; lugares para o encontro, o descanso ou para a circulação rápida; calçadões; parques vistos como locais de reencontro com a "natureza", dentro de uma visão pitoresca e romântica, e a rua, sobretudo nas metrópoles e nas grandes cidades, como um espaço fundamental para a circulação de veículos, sendo ainda, por vezes, em áreas mais pobres ou, em fins de semana, em áreas de estratos de renda média, utilizadas para convívio e lazer.

Neste contexto, São Paulo apresenta hoje contrastes amplamente conhecidos de oferta de equipamentos públicos e de áreas qualificadas para o uso coletivo, quer pela sua dimensão, quer pela sua ocupação, sobretudo na sua periferia, formando 
um desenho fragmentado do tecido urbano na paisagem e onde grande parte desses espaços encontram-se perdidos no descaso e no abandono dos órgãos públicos.

A partir destas constatações este trabalho volta-se ao estudo do sistema de espaços livres da Cidade de São Paulo, mais especificamente de uma parcela da Região Sul da cidade, compreendida pelas Sub-prefeituras da Capela do Socorro e de Parelheiros. Foi escolhida esta região por se tratar de parte de um dos lotes de intervenção do Programa Centros de Bairro, como veremos a seguir, e por possuir apropriações e situações bem diferentes de implantação. Também foi nessa região onde houve um apoio maior do subprefeito e uma melhor relação de pré-projeto com a comunidade.

O primeiro capítulo volta-se para um referencial teórico com a finalidade de embasar a argumentação e delineamento da pesquisa, constituindo um quadro conceitual que de conta da questão da totalidade dialética do espaço e que possibilite uma aproximação estrutural à realidade concreta dos estudos de casos, sem perder a qualidade da percepção específica da paisagem e dos espaços a serem investigados; estabelecendo, assim, uma primeira base de parâmetros na discussão da realidade da cidade de São Paulo frente à estruturação, uso e apropriação dos espaços livres públicos.

O capítulo dois relata o processo de urbanização da cidade de São Paulo desde a sua colonização até a consolidação de sua periferia na década de 1970 , proveniente da rápida expansão da mancha urbana, resultante de transformações sociais, políticas, econômicas e culturais, decorrentes principalmente do desenvolvimento do setor industrial; e de suas implicações na configuração de seu sistema de espaços livres; tema do capítulo três, que busca a compreensão do processo de sua formação até os dias de hoje, inclusive da incorporação do lazer ao seu programa de necessidades e de sua relação com o tempo livre dos trabalhadores. 
A partir daí, o quarto capítulo apresenta o estudo de caso-o Programa Centros de Bairro, criado pela Prefeitura do Município de São Paulo em 2001, sobre a gestão da então prefeita Marta Suplicy e que é apresentado neste capítulo como um elemento constituinte do sistema de espaços livres da cidade de São Paulo. Aqui, o método de pesquisa baseou-se na participação direta da pesquisadora em parte do processo de elaboração dos projetos e na efetiva vivência do dia-a-dia da implantação das praças, observando o cotidiano de cada área e na coleta de informações em entrevistas e conversas com os coordenadores do programa, arquitetos e agrônomos responsáveis, além de conversas soltas com os moradores e freqüentadores de cada praça.

$\mathrm{O}$ trabalho procura num primeiro momento identificar e entender o processo de idealização e formação do programa, questionando os entraves e conflitos iniciais na elaboração dos projetos, tentando estabelecer parâmetros e resgatar as diretrizes formadoras do programa como um sistema, para finalmente entrar na problemática da manutenção dessas áreas.

Em seguida, o capítulo cinco adentra no cotidiano das intervenções do programa realizadas na Região da Capela do Socorro buscando compreender o processo de apropriação e ocupação desses espaços livres públicos e sua relação com a configuração do sistema de espaços livres da região e da cidade de São Paulo.

Faz-se aqui uma análise da relação destas praças com áreas públicas já consolidadas, e da efetiva contribuição do Programa Centros de Bairro para a conformação de um sistema de espaços livres públicos mais estruturado para a cidade de São Paulo.

Por fim, são analisadas as 4 praças que o Programa implantou na região da Capela do Socorro: o conjunto habitacional brigadeiro faria lima - o bororé, av. ipanema $x$ av. dos lagos, a várzea do córrego são josé e a praça do trabalhador; suas 
relações com os usuários destes espaços, com o bairro, com o distrito e com a cidade; procurando identificar as transformações sociais e ambientais que essas intervenções causaram a estes. 
n t rod ução 


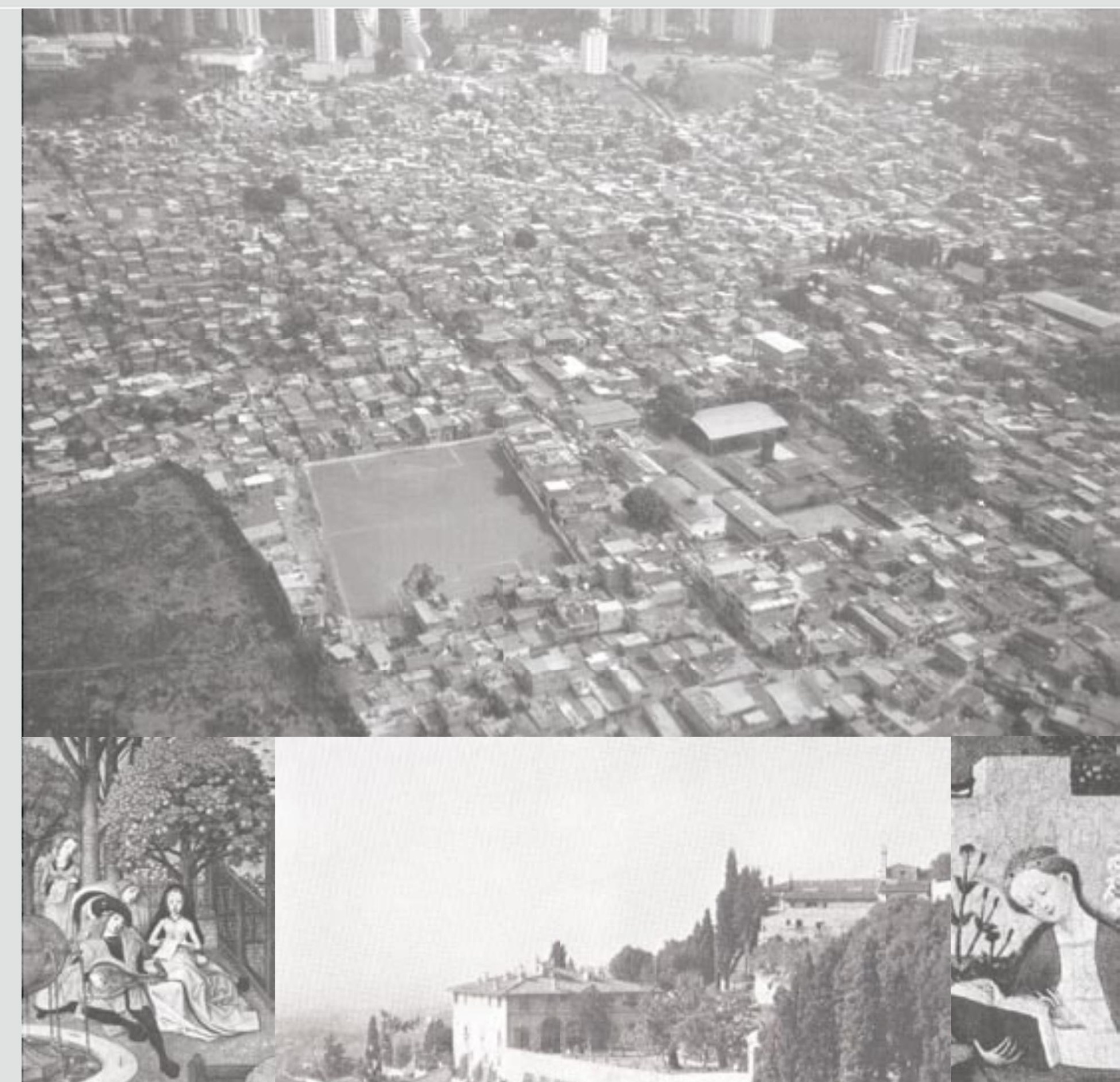

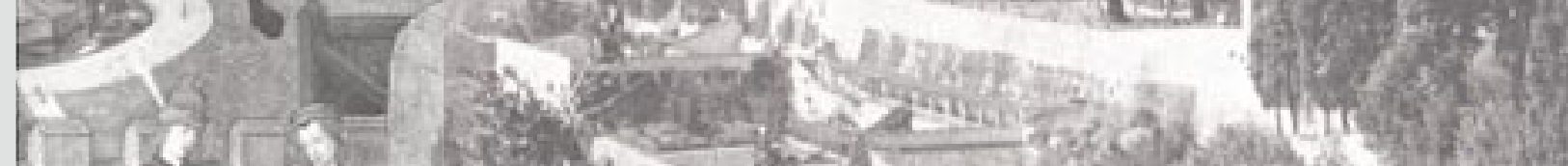

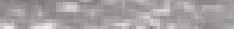

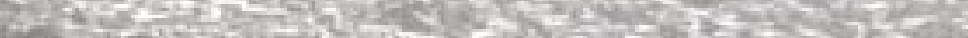

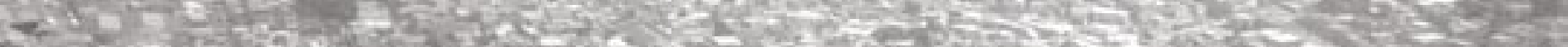

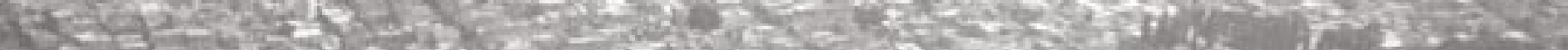

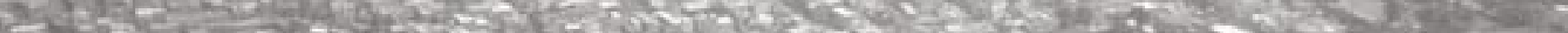
El

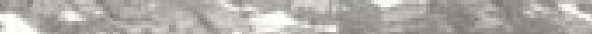

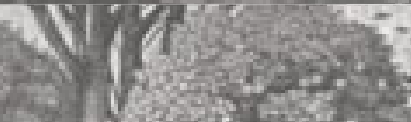

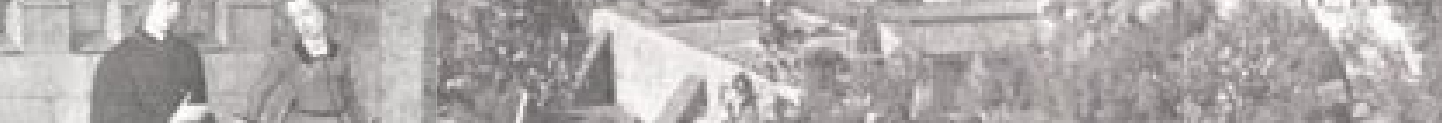
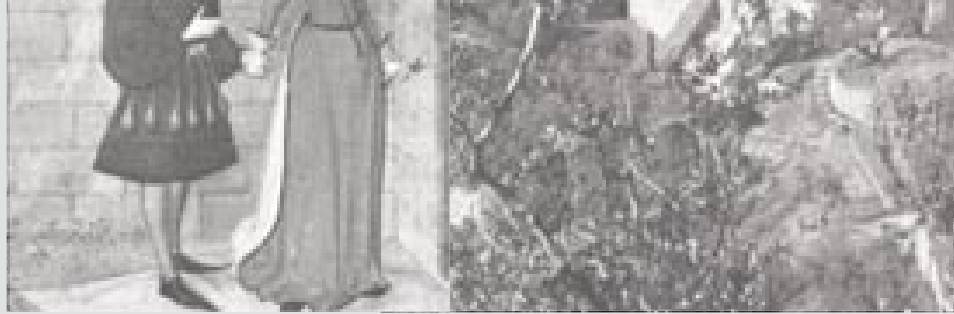

6.

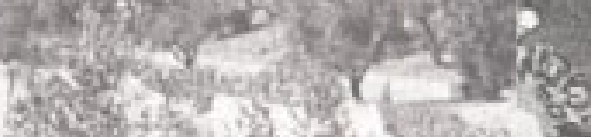

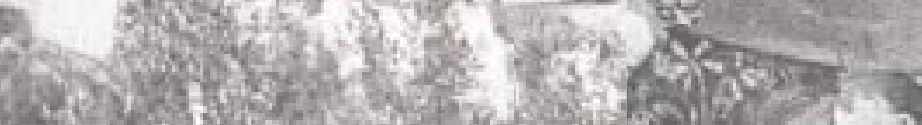

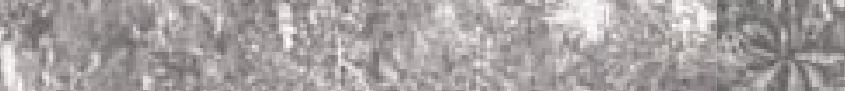
. 


\section{Capít ulo 01 CONCEITOS FORMADORES}

Este capítulo apresenta um caráter teórico e tem por finalidade a busca de referências bibliográficas como fonte de argumentação e delineamento da pesquisa, constituindo um quadro conceitual geral que fundamente os princípios metodológicos adotados no decorrer da pesquisa.

$\mathrm{Na}$ cidade de São Paulo são cada vez maiores as demandas por espaços livres, em especial aqueles destinados ao lazer, convívio, conservação e preservação. Percebe-se alguma preocupação com o projeto e manutenção dos espaços livres de circulação e acesso, como ruas e avenidas, enquanto o tratamento de praças, parques e outros espaços livres de edificação são deixados em segundo plano pelas diversas gestões municipais, responsáveis pela normatização, fiscalização, produção e gestão de grande parcela do sistema de espaços livres urbanos.

Paralelamente a esse quadro, existe uma grande imprecisão na conceituação do termo espaço livre, freqüentemente confundido com a idéia de área verde.

Diante dessa realidade, os conceitos aqui apresentados tomam como base a conceituação sobre espaço e lugar desenvolvida pela geografia crítica de Milton Santos $(1988,1996)$, a leitura dos significados dos lugares, apresentada por Lucrécia Ferrara (1991,1993 e 2000) e as ricas discussões do grupo de pesquisa nacional QUAPÁ-SEL, que se volta para o estudo teórico e metodológico dos sistemas de espaços livres nas cidades brasileiras; e onde estão sendo discutidos conceitos como espaço livre, sistema de espaços livres e áreas verdes. 
1. Conceitos Formadores 


\section{Es p a ço e L u g a r}

Nesta pesquisa o termo espaço está sendo entendido, como por alguns geógrafos, como uma totalidade. Milton Santos apresenta o entendimento do espaço como uma instância social, ao mesmo nível da instância econômica e da instância cultural, ideológica e política; um conjunto indissociável de sistema de objetos e de ações. Desta maneira a dialética social não se estabelece apenas no espaço, mas se realiza com o espaço.

Porém, a dimensão propositiva do olhar do arquiteto induz a fragmentação dessa totalidade em subespaços - espaço urbano, espaço livre, espaço verde... Assim os subespaços são categorizados, recebendo as qualificações, de modo que se diferenciem de outros para atender às especificidades e diferenças de escala.

O espaço como um sistema de objetos e ações, é uma instância social, pois é produto da natureza transformada pela sociedade. Ë o resultado da sociedade, que se caracteriza pelo seu processo histórico e dinâmico; podendo ser apreendido de diferentes maneiras, conforme a percepção de quem o capta.

Já os lugares são uma categoria deste espaço e se constituem como espaços da co-presença, do acontecer solidário - organizacional e orgânico. Os lugares, mais do que nunca, são onde se realizam as ordens globais, mas são também o espaço de resistência, onde colidem as diferentes racionalidades, sistêmicas e comunicacionais, constituindo-se, na dialética da cotidianidade, espaço para a surpresa, não apenas para a manutenção do modo de produção dominante.

Com a globalização, o lugar passou a ser o intermédio entre o mundo e o indivíduo. Essa dialética se instala no desenvolvimento dos sistemas sociais pela unidade das tendências opostas: a individualidade e a globalidade, onde todos os lugares são virtualmente mundiais.

Assim, toda a análise do lugar deve levar em conta o que 
é local e o que o caracteriza, mas também, o que é global e interpenetrando-o no local, criando uma outra realidade, ainda que local, mas completamente diversa da primeira.

O desafio portanto é a descoberta do lugar dentro da dimensão global e daquilo que é a sua essência dentro das variáveis: objetos, ações, técnica e tempo. A atividade racional é invadida pela atividade simbólica, o que resulta em um novo espaço: um lugar objetivo e impregnado de símbolos subjetivos, é assim que se refazem valores. E é neste espaço que os homens exercitam suas virtualidades de valores desiguais e onde se materializam as ações e os usos advindos da força de cada qual.

Segundo Milton Santos, a cidade é o lugar onde há mais mobilidade e onde existem mais encontros. Nela dois fenômenos distintos se impõem:

1. a condição de vizinhança, que é o exercício do papel de cada um, no trabalho conjunto, sem inclusive ter de estabelecer relação pessoal, para alcançar, independente de suas vontades, resultados coletivos;

2. a pressão humana que cresce e se expande, o que faz com que a diversidade e a "cultura popular" interpenetrem em todos os espaços assumindo assim sua revanche sobre a "cultura de massas".

No lugar o cotidiano é compartilhado entre as mais diversas pessoas, tendo a cooperação e o conflito como base da vida comum. Ele é o quadro de uma referência pragmática do mundo, do qual the vêm solicitações e ordens precisas de ações condicionadas, mas é também o teatro insubstituível das paixões humanas, responsáveis, através da ação comunicativa, pelas mais diversas manifestações da espontaneidade e da criatividade. (SANTOS, 1996)

Com a globalização, todos os lugares se mundializaram. Mas há lugares globais simples e lugares globais complexos. Nos primeiros apenas alguns setores da modernidade atual se 
instalam. Nos lugares complexos, que geralmente coincidem com as metrópoles, há profusão de vetores.

As grandes cidades são dessa forma as únicas capazes de absorver os pobres expulsos do campo e abrigá-los dentro de uma diversidade sócio espacial que a enriquece. É nesse espaço que se criam os subespaços de lugar e onde os excluídos se agregam, exercendo as mais diversificadas relações de trabalho e produção, inclusive, como meio de manutenção do sistema imposto pelas classes economicamente dominantes, mas que também abre fendas e onde acontece o exercício da solidariedade e a imposição de sua forma de estar no mundo.

As grandes cidades são, portanto, os locais por excelência onde os homens lentos vão exercer sua cidadania pois, postos diariamente de frente aos seus conflitos e divergências, passam a integrar uma sociedade de consumo, de tudo, material e imaterial, porém não the é dado acesso livre às informações e aos lugares. Assim os homens lentos acabam descobrindo fabulações que lhe permitem olhar para o futuro. Por outro lado, os ricos por possuir mobilidade, vivem na cidade luminosa, rotineira e sem surpresa, permanecendo desta forma inertes e de maneira repetitiva à realidade construída por eles e para eles, dentro de uma cultura de massas.

Já a cultura de massas é indiferente à ecologia social. Ela responde afirmativamente à vontade de uniformização e indiferenciação. Por outro lado, a cultura popular tem raízes na terra em que se vive, simboliza o homem e seu entorno, encara a vontade de enfrentar o futuro sem romper com o lugar e dali obter a continuidade, através da mudança. Seu quadro e seu limite são as relações profundas que se estabelecem entre 0 homem e seu meio, mas seu alcance é o mundo.

Assim vivemos na era da mobilidade e das mudanças, onde a velocidade da sucessão de eventos é vertiginosa, a circulação se sobrepõe à produção, "tudo voa", e o homem se desterritorializa e com isso, também, se desculturaliza. 
Entretanto, sejam os pobres ou os estrangeiros que acessam a metrópole, estes são obrigados a olhar para frente, a memória passada não lhe serve para nada na sua nova experiência. Passado o primeiro momento de atordoamento, esse homem começa a assimilar e a assumir a nova territorialidade e a nova cultura, mudando o seu ser. "Quando essa síntese é percebida, o processo de alienação vai cedendo ao processo de integração e de entendimento, e o indivíduo recupera a parte do seu ser que parecia perdida" (SANTOS, 1996).

Assim enquanto a memória é coletiva, o esquecimento é individual, e se impõe nas relações interpessoais. Esse novo indivíduo é atingido frontalmente pelo diverso e o que parecia inferioridade, se inverte, e a descoberta de novos caminhos são a eles impostas, mas se tornam mais fáceis.

A memória olha para o passado. A nova consciência olha para o futuro. O espaço é um dado fundamental dessa descoberta. Ele é o teatro dessa nova ação do ser. Ao mesmo tempo, futuro imediato e passado imediato, num presente que ao mesmo tempo é concluído e inconcluso, num processo sempre em renovação.

Desta forma, a consciência pelo lugar se superpõe à consciência no lugar. A noção do espaço desconhecido perde a conotação negativa e ganha um acento positivo, que vem do seu papel na produção da nova história.

\section{P a i s a e m}

A paisagem é um recorte do espaço. É uma categoria interna da totalidade. Mas, para entender a paisagem é necessário compreender suas diferentes acepções, para então se fazer uma análise crítica que sirva de base para nós arquitetos e urbanistas podermos utilizá-la e relacioná-la a um novo desenho proposto - e mais especificamente no que será 

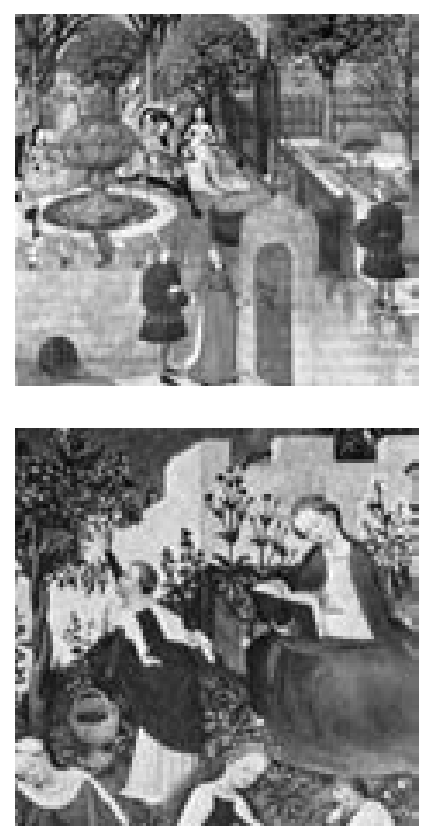

Fig. 1 e 2. Um agradável jardim para passear cercado por muros era o ideal simbólico dos jardins medievais. A cima

"Roman de la rose" e abaixo "Jardin Del paraíso", ambas do século XV.

Fonte: JELICOE, "EI paisage Del hombre", pg. 146 aqui discutido, o espaço público - para poder então qualificá-la, requalificá-la ou revitalizá-la.

Para isso primeiro é preciso conhecer a paisagem, e isso significa entrar em contato com ela, experimentá-la, para depois enxergá-la sobre um outro plano e aí sim, refletir sobre ela e propor o novo. Assim, perceberemos quantos questionamentos e soluções ela nos traz, junto com o cotidiano.

O século XIV viveu um período de transformação da relação entre o homem e a natureza. Até então havia uma negação à paisagem, que se refletia na pintura e nos jardins da época. A natureza era, muitas vezes, vista como um "pano de fundo" e representada através e símbolos.

Alguns dos espaços livres que existiam nas cidades medievais eram cercados e funcionavam como uma extensão da vida privada. Não havia acesso, nem interesse, à paisagem exterior, nem como pequenos espaços abertos para a realização da vida cotidiana. (Fig. 1 e 2)

Neste período, Petrarca, no relato de sua ascensão ao Monte Ventoux, movido pela curiosidade e, a princípio para usufruir a vista de cima; inaugura uma nova forma de ver a natureza, não mais de uma forma simbolizada e sim através da experiência vivenciada da paisagem vista de cima, marcando uma transformação do olhar sobre ela.

Em meados do século XVI e com esta nova forma de ver a paisagem, o pintor Peter Brueghel em uma série de estampas chamadas Grandes Paisagens, apresenta a Terra como uma imagem na qual o homem é visto como participante exterior à cena; onde a paisagem se faz imagem e experiência visual do mundo. As personagens presentes nessas cenas passam a ser interpretadas como expectadores que possuem um olhar dirigido para o mundo, além de representantes de um pensamento do que é o mundo e o que é uma possível visão do mundo. (Fig. 3)

Com isso, Brueghel coloca em cena não apenas o mundo, mas a relação entre o mundo e o olhar. Não se trata mais de 


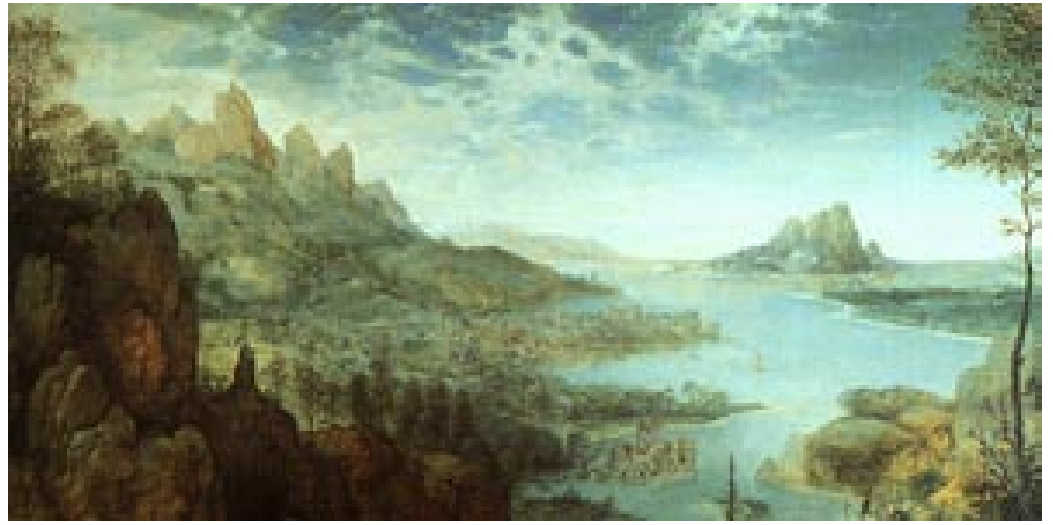

apenas ver, mas, também, de estar na paisagem.

Essas transformações também são percebidas nos jardins do Renascimento. Estes, ao invés de serem fechados como os jardins medievais, passam a se abrir para a paisagem.

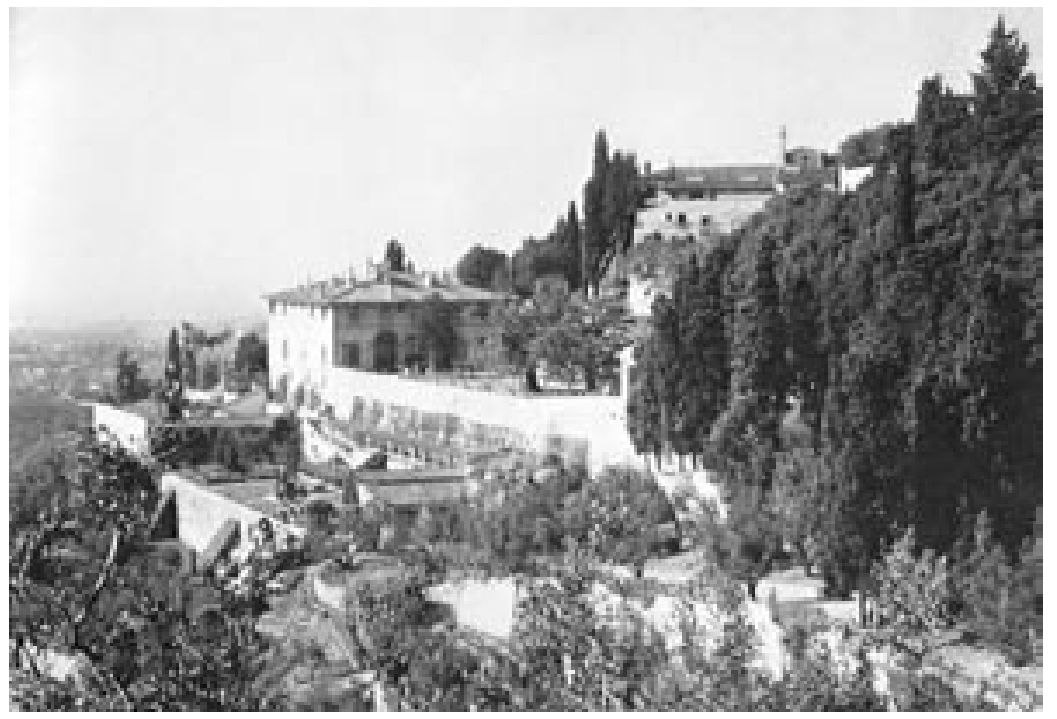

Porém, a paisagem não pode ser compreendida apenas como uma representação da ordem estética (apesar de ter sido um postulado amplamente divulgado) que, assim como na pintura era apresentada como um mecanismo de projeção subjetiva e cultural. Há uma realidade além dessa representação unicamente de uma "vista".
Fig 3. Peter Brueghel, século $X V I$.

Fig. 4. A primeira vila renascentista de Michelozzo Michelozzi, a Villa Médicis em Fiesole em que os jardins foram implantados em terraços, apropriando-se a topografia existente e trazendo a paisagem para dentro do projeto. 
A paisagem é, antes de mais nada, um território ou um sítio, em que a questão que se coloca é como conseguir apreender a relação entre a dimensão do visível e aquela que não o é.

"Ler a paisagem é extrair formas de organização do espaço, estruturas, fluxos, tensões, direções e limites, centralidades e periferias"2

A paisagem passa a ser, então, para alguns geógrafos no início do século $X X$, um produto das interações entre as contribuições geológicas, morfológicas, botânicas, .... e um conjunto de aspectos antrópicos como fatores econômicos, sociais e culturais. Essas interações no tempo e no espaço seriam responsáveis pelas transformações pevircebidas na paisagem.

Mas, qual seria o sentido e o interesse em conceber a paisagem não como uma representação mas como uma fisionomia ou uma expressão?

Esse foi um dos conceitos fundadores da geografia humana no século XX. Paul Vidal de la Blache coloca que, para compreender a fisionomia de uma região, precisamos levar em consideração suas características, ou seja, tudo aquilo que a assemelha e a distingue entre todas as outras. Fisionomias e características não são mais representações subjetivas ou seus fictícios forjados para as necessidades da análise do geógrafo, são realidades objetivas que identificam um território.

Assim, o aspecto do território passa a ser não mais uma aparência do sensível que deva ser rapidamente abandonada para se reencontrar sua verdade teórica, ao contrário, é sobre o plano das aparências que é preciso se situar, para apreender

${ }^{2}$ BESSE, Jean Marc. Ver a terra: seis ensaios sobre a paisagem e a geografia. Tradução Vladimir Bartalini para a disciplina AUP $5834-1^{\circ}$ semestre 2005 toda sua densidade epistemológica e ontológica. A paisagem passa a ser então, uma impressão.

Eric Dardel, apud Besse, diz que a paisagem é a forma como é escrita a superfície da terrestre. Nela existe uma grafia 
objetiva na qual, o saber geográfico é fundamentalmente apreender a leitura da decodificação dos signos dessa escrita, que são os desenhos das costas, os contornos das montanhas, as sinuosidades dos rios, mas também as diferentes formas de estabelecimento sobre a terra.

$\mathrm{Na}$ segunda metade do século passado, a geografia humanística passou a ter relações estreitas com a fenomenologia, encontrando teorias e métodos que lhe permitiram renovar seus objetivos, seus discursos e suas práticas. Erwim Straus trabalha a diferença entre o sentir e o perceber, e é na concepção fenomenológica do sentir que entra a paisagem, diferentemente da geografia que se encontra no plano da percepção.

"O mundo da percepção é um mundo de coisas com propriedades fixas (...) num espaço e num tempo objetivos e universais." 3

Para ele a paisagem é o espaço do sentir, ou seja, o foco original de todo o encontro com o mundo, trazendo, mais uma vez, uma ruptura com a concepção tradicional que faz da paisagem uma "extensão de território que se pode abarcar em um lance de vista". A paisagem agora significa participação mais que distanciamento.

Já Milton Santos, em 1996, discute a existência do espaço. O espaço não como paisagem, mas sim como uma instância social, onde é necessário compreender o mundo em que estamos vivendo, para ver o mundo que podemos criar. Para isso, não é possível compreender o espaço sem a questão social, em que o homem faz parte desse espaço e que a paisagem nada mais é que expressões das ações realizadas por ele, estando em constante transformação.

A paisagem pode ser considerada como a resultante das relações entre processos sociais e processos naturais; sendo um sistema na medida em que, a partir de qualquer ação sobre

${ }^{3}$ STRAUS, Erwin. Dus sens dês sens, pág.551. 
ela impressa haverá uma reação correspondente, que equivalerá a uma alteração morfológica parcial ou total. A paisagem é, portanto, sempre dinâmica ou, nas palavras de Milton Santos: "a paisagem é a acumulação desigual do tempo".

Mas, reduzir a paisagem a um sistema material, à dimensão visível dos sistemas de objetos que constituem os lugares e regiões não permite apreender, sobretudo na escala do lugar, a dimensão qualitativa das impressões que caracterizam a noção de paisagem. O sistema de ações atuantes no espaço marca a paisagem, visualizando-se direta ou indiretamente. Para um mesmo sistema de objetos podemos então existir diferentes estados da paisagem pois nele se realizam diferentes sistemas de ações.

Uma paisagem urbana, como por exemplo, a da Avenida Paulista em São Paulo, apresenta diferentes estados - seja pela simples questão de ser dia ou noite, seja pelas ações que diretamente se realizam sobre seu sistema de objetos (passeios, mobiliário urbano, leito carroçável, edifícios lindeiros, sinais gráficos, etc).

A paisagem da Av. Paulista é uma nos dias de semana e outra aos domingos; é uma nas situações do cotidiano de trabalho e outra em dias - cada vez mais freqüentes no presente - de manifestações políticas. Não se pode abstrair da paisagem da Av. Paulista a presença física maior ou menor das pessoas e dos veículos pois, se assim se procedesse estaríamos abdicando inclusive da leitura estritamente visual dessa paisagem, para não falarmos de seus significados.

As relações entre sistemas de objetos e ações não apenas constituem o espaço, mas também as paisagens. As paisagens não somente abrigam os eventos resultantes dos sistemas de ações, como por eles se qualificam e, dialeticamente, os especificam.

Para compreender a paisagem, como já foi dito, não basta termos uma visão de cima - da superfície. É necessário uma 
visão de baixo, de dentro da paisagem e em movimento. É preciso sentir a paisagem, num primeiro momento fenomenológico, livre de pré-conceitos e de categorias analíticas pré-estabelecidas, deixando-se surpreender por ela, descobri-la.

Conforme Besse (2000), em ensaio sobre a filosofia e a paisagem segundo Péguy, é preciso "experimentar a paisagem"; ou, no sentido metodológico preconizado por Bergson (1959), "intuir" qualitativamente a paisagem, muito mais do que induzir ou deduzir. Este é o primeiro, e não menos importante, momento da compreensão da paisagem.

A paisagem apresenta-se então, como fragmento do espaço - total, podendo ser apreendida, numa primeira instância, por sua dimensão perceptível - sensorial - geral e não apenas visual, para a própria ação cotidiana.

Num segundo momento - de natureza geográfica podemos ler racionalmente a paisagem buscando compreender as relações entre os processos que a engendram. No âmbito paisagístico constitui-se um terceiro nível, analítico, onde a compreensão da paisagem não abdica da importância da análise morfológica para a compreensão do sistema de objetos, incluindo seus aspectos estéticos, possibilitando analisar as relações entre formas, usos, impactos e valorações. Neste momento - de natureza paisagística - podemos interpretar a paisagem, num movimento de sínteses, a partir da evocação dos sentidos em interação com o entendimento das formas espaciais concretas e das diversas apropriações pelos diferentes homens, empresas e instituições, abrangendo seus significados simbólicos, suas representações.

Para Macedo, "a paisagem pode ser considerada como um produto e como um sistema. Como um produto porque resulta de um processo social de ocupação e gestão de determinado território. Como um sistema, na medida em que, a partir de qualquer ação por ela impressa, com certeza haverá uma reação correspondente, que equivale ao surgimento de uma alteração 
morfológica parcial ou total".

Assim, esses "produtos e sistemas" nascem do espaço apreendido e vivenciado e podem ser percebidos diferentemente conforme os padrões culturais presentes nos diversos grupos sociais. A paisagem, portanto, depende de uma dimensão perceptiva, mas tem, ao mesmo tempo, uma materialidade efetiva vinculada a uma dimensão temporal. Desse modo, ela é a acumulação dinâmica de produtos de processos sociais e naturais que resultam numa fisionomia percebida pelo observador de um dado instante, possibilitando a descoberta do novo. O novo percebido no cotidiano pode ser identificado como fragmentos ou unidades da paisagem.

\section{A e sfer a d a vi d a pú b I i a e o cot id i n o}

Se o lugar é a manifestação mais concreta do espaço banal, o cotidiano é a manifestação mais concreta da história. Os marcos das grandes revoluções pouco valeriam se depois delas, não se estabelecesse nesses lugares, uma mudança na vida cotidiana. É na esfera do cotidiano que se entrelaçam a alienação e a percepção do mundo, no dia a dia das pessoas algumas atitudes são pragmaticamente exercidas, outras propiciam reflexão. $\mathrm{Na}$ transversalidade de relações que caracteriza os lugares do território megalopolitano, o hibridismo de ações caracteriza os diferentes processos cotidianos das pessoas e mesmo das empresas e instituições. A diversidade é a potência do reconhecimento e da mudança. O cotidiano megalopolitano abrange um amplo arco de ações, de dominação, de competição e violência, mas também as ações e solidariedade orgânica, da comunicação. Tem-se simultaneamente, no cotidiano megalopolitano, desde processos que acentuam o individualismo até os que vão na direção inversa, da individualização. 
(QUEIROGA, 2001, pág. 212)

Como afirma Agnes Helller (1970), a vida cotidiana, para se realizar, impõe a cada indivíduo uma série de pragmatismos, de economicismos, juízos provisórios, processos de ultrageneralização, em várias de suas ações; sendo impossível a reflexão mais rigorosa se antecipar a todas as questões que impõem à vida, a cada evento, em todos os níveis. Desta forma, rotinas se estabelecem na vida cotidiana, que é, de todas as esferas da realidade, a que mais se presta a alienação, a participação inconsciente do indivíduo no processo.

Já a esfera de vida pública é, nas palavras de Hannah Arendt (1958), a esfera própria da vita activa, da ação política, entendida em sentido amplo, envolvendo a produção cultural, a construção da cidadania e parte fundamental das próprias histórias civilizacionais. Na esfera pública as diferenças e divergências têm, ou teriam, a possibilidade de se apresentar através dos discursos comunicativos (visando o entendimento mútuo, uma verdade processual), daí decorrendo o acordo político em seu sentido maior, a noção de interesse público, de bem público, constituído socialmente diante do conflito de interesses, individuais ou de grupos. Vale observar que o bem público não se confunde com a noção de bem comum, o primeiro é fruto da construção dialética da política, o segundo, se produz enquanto ideologia da classe dominante. A esfera pública se constitui no domínio da liberdade, da instância cultural; a esfera privada se relaciona, primordialmente, ao domínio das necessidades, portanto, da instância econômica. (QUAPA/SEL, 2006 - Prof.Dr. Eugenio Queiroga)

Mas nem tudo que está além da esfera de vida privada se constitui na esfera pública, a sociedade capitalista contemporânea não apenas fortaleceu a esfera de vida privada como também, uma esfera social. Esta esfera se caracteriza por acessos restritos a determinados grupos sociais, em que o mundo do negócio e do ócio se produz, em boa medida, para além da vida 
privada e aquém da vida pública.

Não se trata simplesmente de um declínio do homem público, mas de uma metamorfose da esfera pública, como elemento estrutural da sociedade burguesa. $\mathrm{Na}$ contemporaneidade, Habermas afirma a existência de uma razão pública, a partir da razão comunicativa, estabelecida no mundo vivido cotidianamente, tendo inclusive, a Internet como meio para sua expressão. É possível, portanto, compreender novos modos, escalas e significados para a vida pública.

Os novos meios informacionais e telecomunicacionais não homogeneízam, evidentemente, as sociedades e suas esferas de vida, próprias a cada formação sócio-espacial. No Brasil, a apropriação privada do território vem marcando nossa história desde o período colonial. Da aristocracia rural e do regime escravocrata herdaram-se práticas de legitimações das desigualdades sócio-econômicas, construindo-se uma nação de cidadania incompleta, uma esfera pública peculiar.

Porém, é no cotidiano que a vida humana se manifesta e onde se revelam os conflitos e as contradições de cada sociedade em seus diferentes momentos históricos.

A dimensão cotidiana, por sua própria estrutura de exigência de múltiplas tomadas de decisões diárias, constituise em espaço por excelência da espontaneidade, resultando em processos criativos, em potencialidades de ruptura do previamente estabelecido.

Para Habermas e para Milton Santos a comunicação é a base para a consciência e a transformação. Milton Santos já atribuía ao cotidiano fundamental importância no processo de redescoberta e ampliação da consciência pelas regras de convivência no lugar onde se vive. É no lugar que se estabelece o acontecer solidário, a comunicação.

A percepção não determina mas orienta as práticas espaciais do cotidiano. Os processos de leitura da percepção do ambiente urbano, seletiva em função dos filtros culturais dos 
diferentes grupos sociais, podem auxiliar no estudo sobre a apreensão do cotidiano.

A produção do cotidiano "contemporâneo" reproduz um modo de vida urbano que evidencia a cultura de massas e a globalização, com a padronização de procedimentos e condutas que tendem a homogeneizar os comportamentos e demandas dos indivíduos. Esta dualidade entre a individualidade particular e a própria genericidade humana de cada indivíduo que, caracteriza o ser humano e é exacerbada nos dias de hoje, evidencia-se na produção do espaço livre urbano, ao mostrar a convivência, nem sempre pacífica, entre as esferas pública e privada, entre o contemporâneo e o tradicional, entre o indivíduo, os grupos e o coletivo.

No entanto, é na vida diária que se expõem as possibilidades de transgressão destes modelos aparentemente consolidados, através das expressões pontuais que resgatam práticas tradicionais comuns de diferentes grupos sociais e, sobretudo, criam-se novas formas de sociabilidade que geram lugares de encontros e apropriações imprevistas que renovam o espaço urbano.

\section{Es paços I ivres públicos}

A estrutura espacial das cidades é composta de duas categorias de sub-espaços: os espaços edificados e os espaços livres de edificação, e o que os diferencia é a ausência de estruturas edificadas que configurem recintos ou ambientes cobertos e fechados, isto é, ausência de paredes e tetos (MAGNOLI, 1982).

Assim, os espaços livres de edificação podem ser divididos em tipologias diferentes como: ruas, calçadas, quintais, pátios, terrenos baldios, parques, praças, além de outros. A articulação entre esses diferentes espaços livres e edificados configura e 
qualifica a forma urbana, organizando seus diversos tecidos.

O espaço livre normalmente está associado às áreas verdes na cidade e aos jardins urbanos, porém ele pode ser "verde" - com vegetação, ou árido, molhado, etc.

A área verde é qualquer área que contenha vegetação em solo permeável, sendo assim uma categoria dos espaços livres de edificação, públicas ou privadas. Sua definição está frequentemente associada a índices de origem duvidosa que qualificam ambientalmente as cidades.

O espaço público é aquele de propriedade e apropriação pública. Para Hannah Arendt, o termo público, significa em primeiro lugar, que "tudo o que vem a público pode ser visto e ouvido por todos e tem a maior divulgação possível". Já a esfera pública enquanto mundo comum, reúne-nos na companhia uns dos outros e contudo evita que colidamos uns com outros, por assim dizer. Assim, espaço público é o lugar na cidade da prática de ações na esfera de vida pública. Esta por sua vez, apresenta no espaço suas formas de realização. Ainda que se propague a ideologia de que os novos meios informacionais e telecomunicacionais anulam distâncias, transformam o mundo em uma "aldeia global", o espaço constitui-se em totalidade concreta no qual se processa a sociedade, e onde sem os processos sócio-espacias, não há história.

Desta maneira, no presente, a esfera pública se estabelece sobre o meio técnico-científico-informacional e comunicacional, mais ou menos denso, nesta ou naquela porção do território. O espaço - sistema de objetos e de ações - inclui os novos suportes técnicos que permitem as comunicações e informações teletransmitidas em tempo real

Assim, o espaço público é entendido não apenas como suporte físico - sistema de objetos - onde se realizam as ações próprias da esfera pública, mas como espaço da esfera pública - sistema de objetos e de ações da esfera pública.

No conjunto de espaços públicos de uma dada área 
urbana, pode-se verificar a produção de diversas relações entre seus elementos, constituindo-se, portanto, num sistema de espaços voltados à esfera pública, bastante dinâmico e dele fazendo parte certo sistema de objetos, com maior ou menor intensidade, em função dos eventos públicos neles incidentes.

Os espaços livres urbanos são os espaços livres de edificação; todos eles, quintais, jardins públicos ou privados, ruas, avenidas, praças, parques, rios, matas, mangues e praias urbanas, ou simples vazios urbanos. Tais espaços formam um "tecido pervasivo", sem o qual não se concebe a existência das cidades, estão por toda parte, mais ou menos processados e apropriados pela sociedade; constituem, quase sempre, o maior percentual do solo das cidades brasileiras, mesmo tratando-se de uma cidade tão populosa como São Paulo.

Tais espaços formam um sistema, apresentando, sobretudo, relações de conectividade e complementaridade. Entre seus múltiplos papéis, por vezes sobrepostos, estão a circulação urbana, a drenagem urbana, atividades do ócio, imaginário e memória urbana, conforto ambiental, conservação e requalificação ambiental, convívio público, etc. Esse sistema se apresenta, dependendo da cidade, em maior ou menor grau de planejamento e projeto prévio, com maior ou menor interesse da gestão pública num ou noutro sub-sistema à ele relacionado, constituindo assim, um sistema complexo, dada a inter-relação com outros sistemas urbanos que se justapõem ao sistema de espaços livres (sistema de objetos edificados e seu correspondente sistema de ações) ou se sobrepor, total ou parcialmente, enquanto sistemas de ações.

\section{O S iste ma de Es paços \\ Livres}

Sistema não é apenas um conjunto. Ele se define a partir 
do momento em que os elementos desse conjunto interagem, ou seja, quando eles estabelecem relações. Pode ser definido como uma estrutura que se organiza com base em conjuntos de unidades inter-relacionáveis por dois eixos básicos: o eixo das que podem ser agrupadas e classificadas pelas características semelhantes que possuem e o eixo das que se distribuem em dependência hierárquica ou arranjo funcional.

Assim, sistema é um complexo de elementos em interação com seus atributos próprios e esses atributos também interagem entre si. Nas cidades, o Sistema de Espaços Livres é o conjunto de todos os espaços livres de edificação existentes na malha urbana, sua distribuição, suas conexões e suas inter-relações funcionais e hierárquicas. Portanto, sistema de espaços livres de uma cidade engloba todos os espaços livres de edificação, ou seja, abarca todos os vazios urbanos que envolvem os cheios, e que estão conectados pela atmosfera e tem uma inter-relação de dependência e hierarquia.

A formação do sistema de espaços livres pode ser projetada ou simplesmente decorrente da somatória de diferentes intervenções locais, isto é, a existência de um sistema de espaços livres não presume a existência de um planejamento ou controle eficaz sobre este.

Nas cidades brasileiras encontram-se alguns casos de sistemas de espaços livres parcialmente projetados, como, por exemplo, o sistema de parques de Curitiba e o conjunto de áreas reservadas para futuras intervenções no plano diretor da cidade de Porto Alegre. No entanto, na grande maioria das cidades o sistema é oriundo do modo de ocupação e da somatória das intervenções, o que reforça a condição de descontrole por parte do Poder Público sobre a construção da paisagem urbana.

"O sistema de espaços livres de São Paulo foi (mais) fruto do acaso e da somatória das ações dos empreendedores privados, que da ação premeditada por parte do poder público. Essa forma de produção do espaço urbano, dirigida, como é, 
por interesses privados, resultou num sistema de espaços livres, que se distancia das condições que propiciam melhor qualidade de vida para a população da cidade” (MENNEH, 2002, p.200).

\section{A e s c a l a d a praça}

É ao espaço público que cabe o papel de acolher, em teoria, todas as classes sociais para sua representação pública, desenvolvendo um consistente espírito revolucionário onde a cidadania é uma conquista coletiva e não uma reivindicação de grupos isolados, exigindo assim um espaço público de fruição da comunidade.

A rua além de ser o testemunho da forma do percurso e da forma do parcelamento do solo, ela é o lugar do encontro da vida cotidiana.

A praça, independentemente de sua forma, em sua origem, correspondia a uma abertura privilegiada do tecido urbano, em que sua função principal era o encontro e o comércio, abrigando a própria condição de expressão das relações sociais.

No Brasil, as praças tiveram origem freqüentemente religiosa mas também, abrigaram situações de recreação, comércio ou tiveram caráter político e militar. Porém, a crescente expulsão desses usos em nossas praças, seja pelo descuido ou pela escolha de outras oportunidades, permitiu a livre circulação de "classes perigosas" por esses locais, influenciando assustadoramente a realização da vida ativa do cotidiano.

Essas situações demonstram as contradições ocorridas na construção da paisagem brasileira e a falta de respeito às representações de formas culturais e organizações sociais; simplificando não só a forma de pensar a paisagem, mas também as relações entre sociedade e natureza, numa realidade que insiste em ler a natureza como um vazio.

Sobre esses espaços Eugenio Queiroga diz que: "Pode- 
Fig. 5. Na ausência e espaços públicos de lazer na periferia, as crianças se apropriam de ruas e calçadas para a prática de lazer e convívio. O Campinho de futebol continua sendo um dos únicos equipamentos de esportes e convívio nestes lugares.

Fonte: Ab'Saber, "São Paulo ensaios e entreveros", pág. 479

se falar em sistemas de objetos mais ou menos aptos a se prestarem à condição de praça, mas só diante de uma prática espacial efetiva da esfera de vida pública caracterizadora da praça é que se caracteriza sua pracialidade. Desta forma, várias áreas oficialmente denominadas não o serão se não estiverem comportando um sistema de ações voltado ao encontro e convívio no âmbito da esfera de vida pública." (Fig. 5)

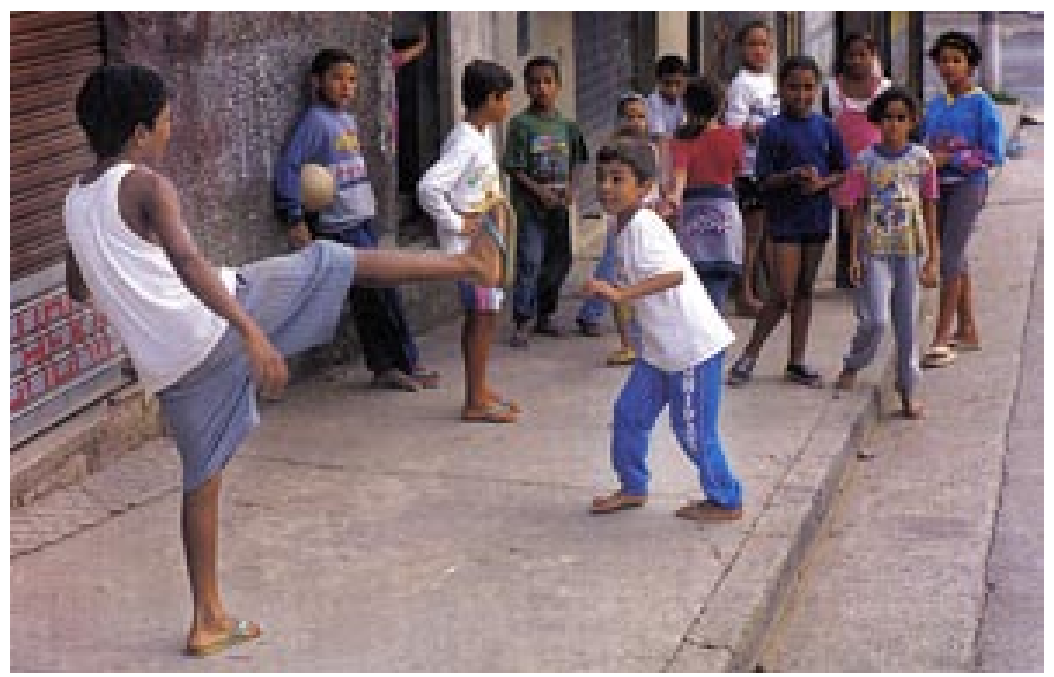

Portanto, diferentes áreas e não necessariamente praças podem apresentar situações de pracialidades, diferenciando-se pelos seus usos e funções. Uma rua, áreas internas a edifícios, praias,... a partir do momento que se tornam lugares de encontro e manifestação pública, apresentam fortes pracialidades.

O entendimento dessas áreas com a apreensão da pracialidade existente torna-se fundamental para a implantação de desenhos adequados para a constituição de espaços públicos, em áreas de grande complexidade e capazes de instituir lugares para o convívio e a prática da vida pública; mesmo tratando-se de fragmentos do tecido urbano.

O que acontece muitas vezes, é que a favor da prática da arquitetura e urbanismo contemporâneos implantam-se desenhos completamente alheios às ricas tramas urbanas de 
relações sociais, sem levar em consideração a vocação de cada uma dessas áreas.

\section{A praça na periferia}

$\mathrm{Na}$ escala de uma cidade como São Paulo, as praças se constituem como um lugar propício à razão comunicativa colocada por Milton, quer na dimensão cotidiana da esfera da vida ativa quer na escala política, principalmente na sua periferia e na área central.

É na praça que se dão simultaneamente, processos de identidade e alteridade, se potencializam racionalidades não hegemônicas, cotidianas e comunicativas. O contato interpessoal estabelece uma racionalidade inter-subjetiva que não exclui, no processo, a emoção, ainda que mediada pelos filtros sócioculturais introjetados em cada interlocutor.

A ação do Estado é mínima na constituição de áreas livres nos bairros da periferia. São raras as praças efetivamente implantadas e mantidas pelo poder, tornando-se fundamentais os espaços livres informalmente constituídos pela própria população.

Os desenhos dos projetos implantados podem estimular um maior ou menor campo para a ação comunicacional, porém não são determinantes. A escala e a criação de ambientes de lazer, convívio e recreação satisfatórios é, no que tange a relação entre o projeto e o uso comunicativo, mais importante que a discussão dos movimentos estéticos. O contexto urbano e a cultura dos lugares são, no geral, fatores mais significativos para o estabelecimento da razão comunicativa que o sistema de objetos que caracteriza a forma das praças.

Em diferentes tecidos urbanos habitados encontrados na periferia - favelas, ocupações, conjuntos habitacionais e outros tipos de loteamentos, pode-se identificar diferentes formas 
de apropriação pública dos espaços livres, estabelecedoras de vínculos sociais de identidade, solidariedade e ação comunicativa.

São nesses espaços que as espacialidades do cotidiano revelam sua capacidade de assimilação e transformação das racionalidades hegemônicas pelas populações. A astúcia dos grupos sociais marginalizados garante sua sobrevivência cotidiana e alternativa, inconforme as ordens. Estas áreas são transformadas, sobretudo pelos pobres, em processos mais solidários que competitivos. (QUEIROGA, 2001, pág. 217). Assim, nos bairros pobres, a criação cultural passa a ser um fato cotidiano.

Em seu livro "Quando a rua vira casa", Carlos Nelson nos coloca a rica vida urbana nas ruas do bairro do Catumbi, no Rio de Janeiro, que vai muito além de um espaço de circulação de veículos. Ele nos demonstra como a rua se transforma num espaço de extensão da casa, não no sentido privado da casa mas, como espaço de práticas sociais ligadas ao cotidiano; e nesse sentido a rua se constitui num local de trocas sociais que em alguns locais da periferia da cidade acabam virando "praças" e assumindo um papel de importante espaço público, voltado para o lazer e para o ócio. Ainda que improvisadas e precárias elas tornam-se o espaço principal para a efetivação da esfera de vida pública na escala local do cotidiano de inúmeros bairros da periferia.

Nessas regiões, outros espaços livres públicos de recreação que merecem nossa atenção são os famosos campinhos de futebol, parentes dos antigos "campos de várzea" que eram verdadeiros clubes populares, mas que em nada assemelham a estes em relação ao seu porte e dimensão.

São implantados na maioria das vezes pela própria população, que se organiza e contrata uma "máquina" para fazer o nivelamento no terreno; em situações ainda mais precárias, diminui-se as dimensões do campo, que é implantado 
em qualquer lugar, a partir de um "roçado" feito pelos próprios moradores. Mas, em todos os casos, como nos coloca Queiroga (2001), observa-se como a razão cotidiana, a astúcia nas práticas espaciais, a solidariedade orgânica, é capaz de resolver a questão da criação de espaços razoavelmente adequados a uma das formas de ócio mais disseminadas na população pobre masculina brasileira: o futebol.

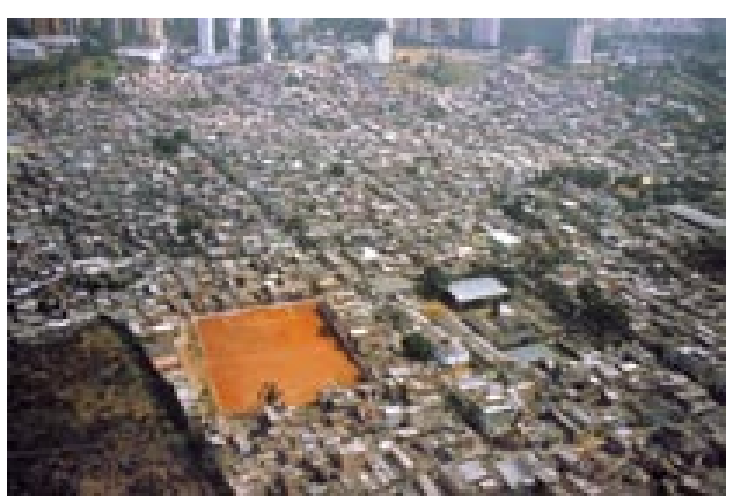

Dada a essa escassez de espaços adequados ao convívio do cotidiano habitacional, a rua acaba se constituindo como um prolongamento da casa, espaço de recreação infantil e de encontros de vizinhança, sobretudo das mulheres, crianças e adolescentes; e onde o contexto intra-urbano acaba contribuindo para um maior ou menor uso destas praças informais, tal como ocorre em qualquer praça oficialmente reconhecida no espaço legal da cidade com a diferença que a tênue centralidade nos bairros mais precários da periferia está menos associada ao movimento de automóveis e sim ao movimento de pedestres e ônibus.

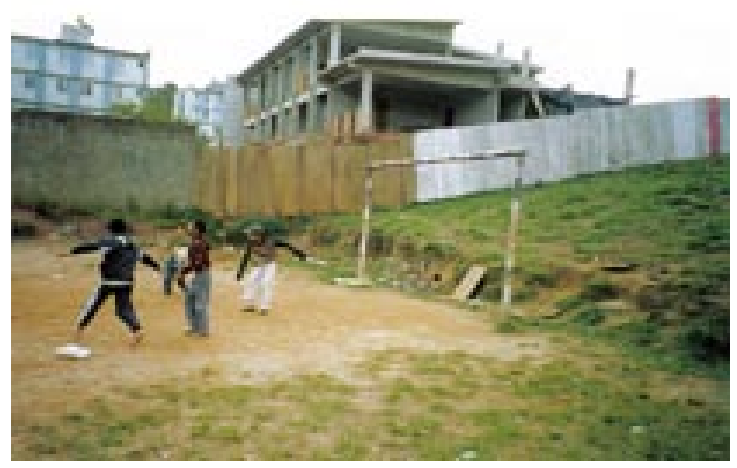

Fig. 6 e 7. Fotos dos atuais Campinhos de Futebol, uma lembrança dos saudosos "campinhos de várzea". 
1. Conceitos Formadores 

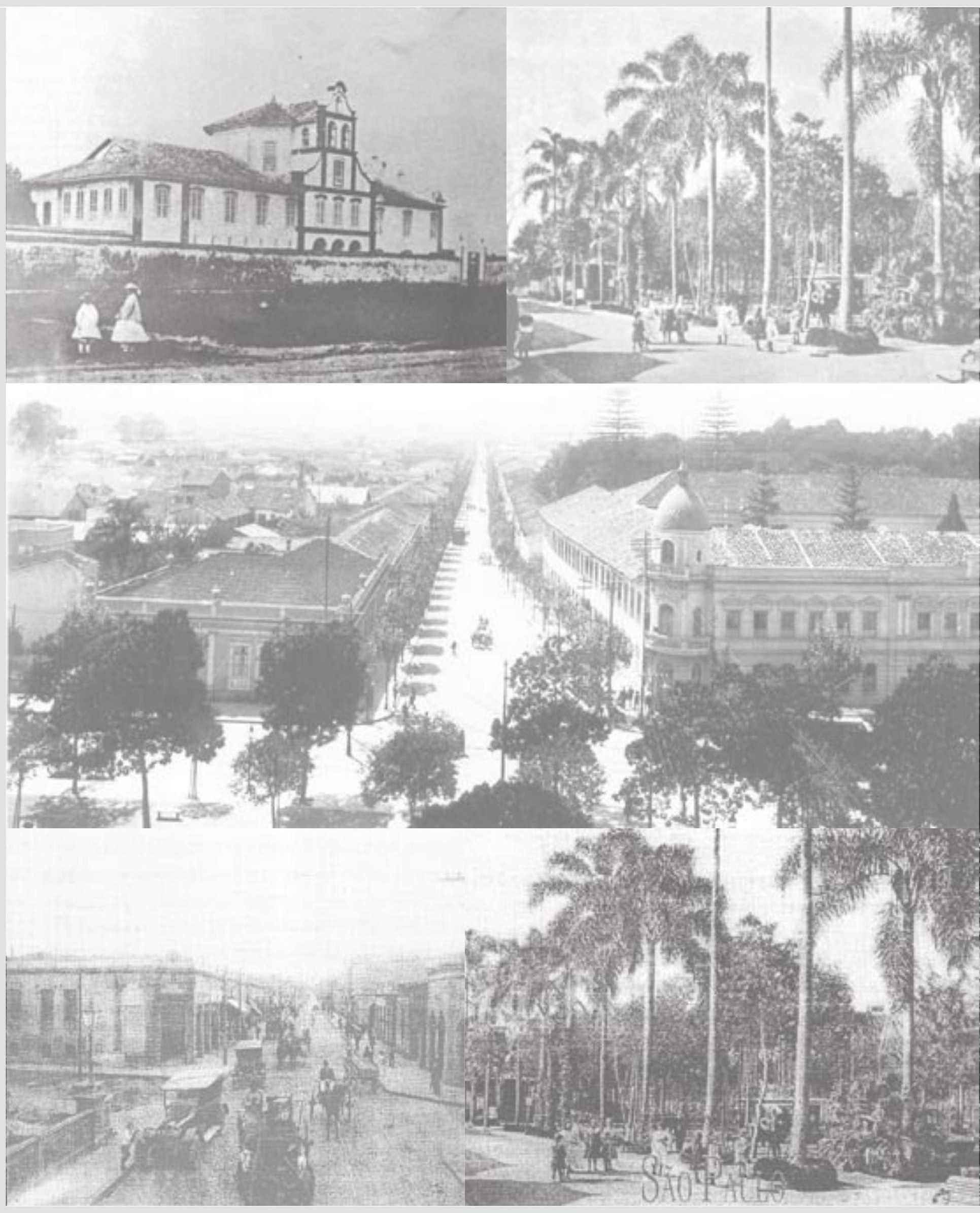


\section{Capít ulo 02 A CIDADE DE SÃO PAULO}

O seguinte capítulo traz um breve relato da formação da cidade de São Paulo desde o início da colonização até a década de 1970, quando consolidou-se a ocupação de sua periferia.

O processo de crescimento urbano do município caracterizou-se, no século $X X$, por um alto crescimento demográfico com a rápida expansão da mancha urbana, resultante de transformações sociais, políticas, econômicas e culturais, provenientes principalmente do desenvolvimento do setor industrial.

Como se caracterizavam os espaços públicos nos séculos XVIII e XIX e quais foram as implicações do crescimento urbano descontrolado na formação do Sistema de Espaços Livres da cidade de São Paulo são alguns dos aspectos tratados. 
2. A Cidade de São Paulo 


\section{U m re l a to d a u r b a n iz a çã o} d e S ão $P$ a u I o

A instalação da colonização portuguesa no Brasil se fez, num primeiro período, dentro do quadro econômico do mercantilismo, montando-se uma estrutura fundiária, latifundiária, cuja base jurídica foi a do direito feudal (a propriedade real e o domínio dos senhores de terras).

A base econômica voltada para a exportação fazia com que as cidades por onde escoavam os produtos primários fossem os principais centros urbanos. Cada região tinha uma relação direta com o centro do sistema, quase não havendo relações inter-regionais, exceto de algumas áreas produtoras para o abastecimento das regiões exportadoras. Estes núcleos urbanos centralizavam o comércio exterior de extensas áreas. No caso de São Paulo/Santos incluíam toda a província de São Paulo (o atual Estado de São Paulo mais o Estado do Paraná), o sul do Mato Grosso, Goiás e parte de Minas Gerais.

Neste período colonial, São Paulo possuía uma dinâmica urbana intermitente, decorrente do afluxo dos senhores de terra. Seu núcleo urbano era pequeno se comparado aos principais centros comerciais do Nordeste (Salvador, Recife, São Luis) ou ao Rio de Janeiro, mas havia um expressivo número de vilas e cidades paulistas em relação às demais províncias. (Fig. 8)

Ainda que populacionalmente menor, a cidade de São Paulo teve uma evolução política e cultural precoce. Em 1554 é fundada a vila; entre 1640 e 1765 é elevada à cidade e à capital ${ }^{4}$

${ }^{4}$ Em Recife, por exemplo, isso só acontece em 1823 e 1827, respectivamente. ${ }^{5} \mathrm{O}$ marco institucional desse processo foi a lei de proibição do tráfego negreiro, em 1850; promulgando-se no país a

"Lei de Terras", instituindo a propriedade privada e abolindo o sistema anterior, baseado no direito feudal. e, na primeira metade do século XIX, já possui o primeiro curso de Direito do Brasil, inaugurado em 1827.

Um segundo período trouxe novas relações sociais de produção, marcado pela economia cafeeira, resultando numa nova estruturação urbana ${ }^{5}$. A Região Sudeste torna-se então a grande produtora de café e, de pobre província, São Paulo, possuindo a maior produção de café, torna-se a região 


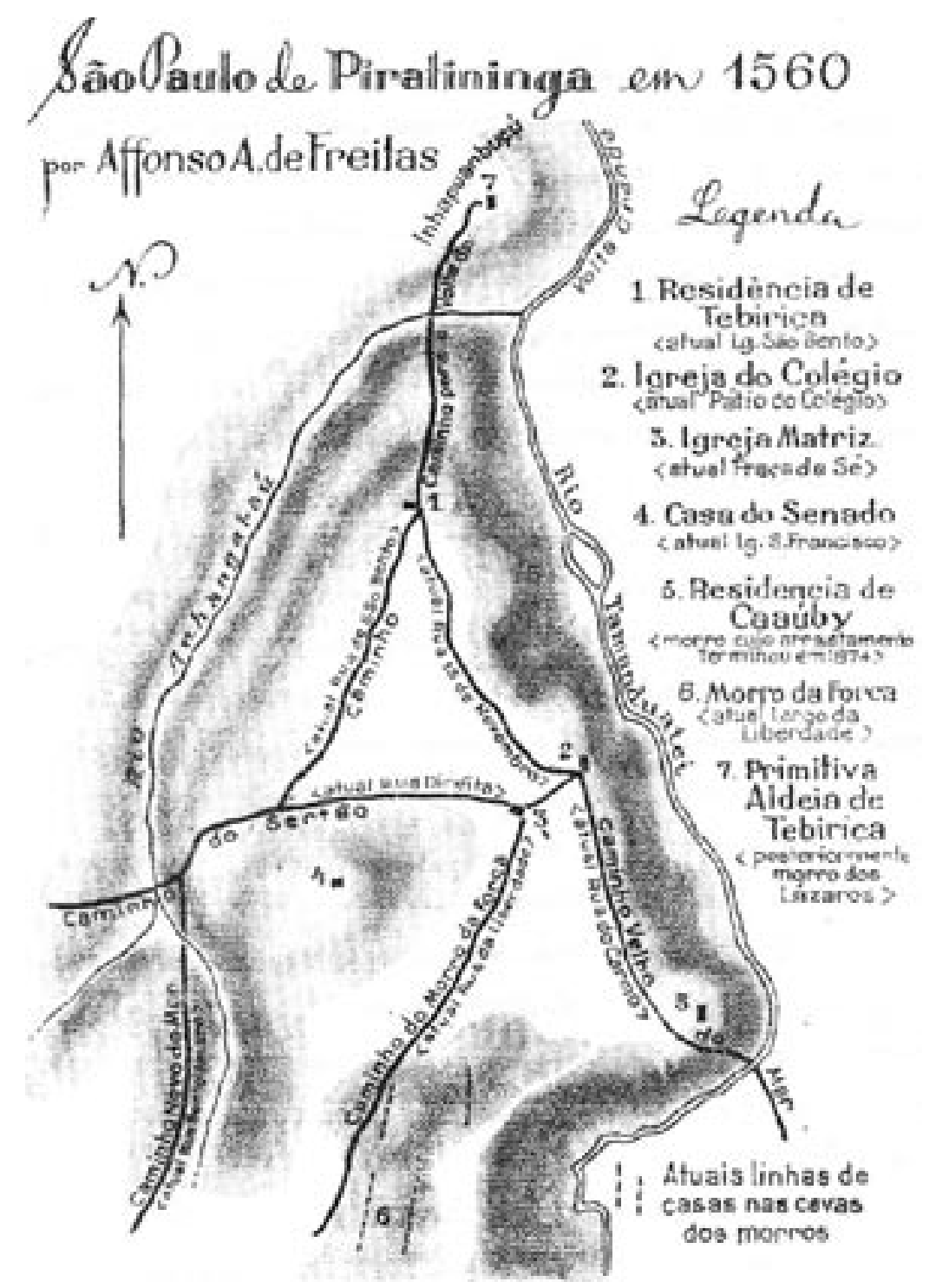

economicamente mais rica do país ${ }^{6}$. Com essas mudanças na economia, outra transformação também alterou as relações sócio-espaciais: o trem como o novo sistema de transportes torna mais dinâmico o centro urbano da província.

Assim, o processo de urbanização de São Paulo caminha em paralelo, a partir da segunda metade do século XVI, com
Fig. 8. Planta de São Paulo de Piratininga de Afonso de Freitas (1560).

Fonte: Biblioteca Mario de Andrade - Setor de Mapoteca.

${ }^{6}$ Em 1915 a produção de São Paulo representava $40 \%$ da produção nacional. 
a formação do bairro da Luz (ou Guaré como era chamado antigamente) que teve sua ocupação iniciada pouco depois da fundação da vila de Piratininga (1554) ${ }^{7}$.

Localizada na região de planície fluvial do Tamanduateí, ao norte da colina onde foi fundada a vila de São Paulo, a região da Luz foi o primeiro vetor de expansão ao redor do "triângulo central" a ser ocupada, não só devido à topografia plana, mas também pela proximidade do núcleo central da cidade.

As plantações de café, inicialmente centralizadas no Vale do Paraíba e posteriormente no interior paulista, criaram uma nova elite que teria como referência a cidade de São Paulo.

No final do século XIX o núcleo histórico da cidade já estava consolidado. Contando com três conventos, um seminário, uma casa de Misericórdia, algumas igrejas e uma casa de fundição para cunhar as barras de ouro extraídas da região. Por relatos de moradores e visitantes dessa época, percebese uma preocupação com a qualidade de vida e o tratamento dos espaços livres, sejam eles públicos ou privados: "Os jardins em São Paulo e suas proximidades, são tratados com grande bom gosto e muitos deles com curiosa elegância. O jasmim é a planta favorita e neste clima magnífico as flores desabrocham perenemente, tal como a rosa... Crescem em grande profusão, um dos arbustos prediletos é a Palma Christi, que dá frutos no primeiro ano, dos quais se extrai o óleo de rícino em abundância... Talvez, além do clima ameno, a beleza natural tenha despertado no paulista o gosto pelos jardins públicos, dos quais existem diversos, muito graciosos, na cidade" ${ }^{\text {. }}$.

Os espaços públicos - praças e largos - até o final do

${ }^{7}$ Em carta José de Anchieta para Manuel Paiva em 1579, já é encontrada uma referência à "pequena ermida da Luz". ${ }^{8}$ BRUNO, Ernani Silva. Memória da cidade de São Paulo: depoimentos e moradores e visitantes. Registros 4. PMSP, 1981, pág.20 a 34 . século XVIII eram pequenos e geralmente se desenvolviam em frente a igrejas e capelas. Na primeira década do século XIX começam as intervenções na chamada Cidade Nova e em plantas da cidade dessa época já começam a aparecer algumas áreas públicas como o Campo Redondo (atual Praça Princesa Isabel) e o local onde hoje é a Praça da República, além do 
Jardim Público (hoje conhecido como Jardim da Luz).

A Faculdade de Direito foi instalada em 1827 ao lado do Convento do Carmo e, passou a atrair estudantes de diferentes lugares. Com isso, estabelecem-se novos hábitos e a cidade começou a "clamar" por uma nova infra-estrutura para atender esses novos moradores.

A vasta planície que se estendia à margem esquerda do Tietê, chamada de Piratininga, era considerada como uma verdadeira terra prometida por sua fertilidade e abundância de caça, e não é surpresa que a população de maior renda procurasse, desde o início do século XIX, estabelecer seus sítios e chácaras nos "Campos de Piratininga", atraídos não só pelos terrenos secos e planos mas também pela proximidade do "charmoso" Jardim Botânico da Luz que, desde 1825, consistia num dos lugares de lazer mais nobres da cidade.

O Jardim Botânico teve um papel fundamental no desenvolvimento da cidade, principalmente por ser um fator de atração, até meados do século XIX, das residências de parte da elite paulistana.

Constituído por um longo processo iniciado ainda no século XVIII, o jardim teve suas portas abertas ao público em 1825. Apesar da alternância entre fases de abandono e atenção, da perda de áreas para a construção da estação da Luz em 1860 e uma drástica redução de sua testada voltada para a Av. Tiradentes com a construção no antigo Campo da Luz do colégio Prudente de Moraes, em 1895, e do Liceu de Artes e Ofícios em 1900, o Jardim da Luz foi um ponto de referência para o lazer do paulistano e o principal cartão postal da cidade até a década de 30 do século passado, quando vários fatores de degradação, tiram-Ihe o status de ponto de encontro da aristocracia.

Assim, para os viajantes vindos de Sorocaba, Atibaia e Bragança, o Campo da Luz era o melhor local da reunião e descanso, antes de adentrar na vila de São Paulo de Piratininga. 
O acesso era feito a partir do centro da cidade através de duas ruas que desciam o triângulo em direção à Luz. Uma, a rua da Constituição, atual Florêncio de Abreu e antiga "estrada do Guaré“, descia íngreme em direção ao Tietê pela face leste da colina e a outra, a rua Alegre, atual Brigadeiro Tobias na margem esquerda do ribeirão Anhangabaú, constituíam o principal caminho para os Campos de Piratininga. Do Campo da Luz, hoje Av. Tiradentes, os viajantes podiam seguir para o sul de Minas Gerais atravessando o rio Tietê ou, mais raramente, cruzar o rio Tamanduateí para seguir em direção ao Rio de Janeiro passando pela Penha e Moji das Cruzes .

Não obstante o bairro da Luz passa a contar já na segunda metade do século XIX com equipamentos que lhe valorizavam, como o Jardim Botânico e o Seminário Episcopal concluído em 1856, mas as alterações de uso da área já no final do século fizeram com que a aristocracia migrasse para longe da região.

A partir de meados da década de 1860, o desenvolvimento da cultura cafeeira em direção ao interior paulista veio alterar profundamente as bases econômicas da província, dando início a um período de riqueza até então jamais experimentado por São Paulo.

A cafeicultura atingiu o interior paulista, passando por Jundiaí e Campinas; e é aí que começam alguns problemas. A expansão da cultura cafeeira ficou condicionada às limitações do sistema de transporte existentes e à capacidade operacional do porto de Santos, para onde toda a produção era dirigida para ser exportada.

Assim, em 1860 é organizada em Londres a São Paulo Railway Company Limited, que passaria a ser conhecida aqui como companhia inglesa, com o objetivo de construir uma estrada de ferro unindo Santos à cidade de Jundiaí, então centro de confluência da produção cafeeira do interior paulista.

Em 1865, essa estrada de ferro já unia Santos a São Paulo. Três anos depois atingiria Jundiaí. Finalmente em 1872, 
outra estrada, a Companhia Paulista de Estradas de Ferro, interligou Jundiaí à Campinas, criando assim todas as condições favoráveis à expansão das fazendas de café pelos sertões além de Rio Claro.

A nova era ferroviária deu à cidade um incipiente status de capital européia. Abandonada a taipa, a nova arquitetura paulista se processava mais velozmente, com o emprego do tijolo e do ferro, como conseqüência direta dessas mudanças; o mesmo trem que descia a serra transportando café, subia de volta trazendo novos materiais e técnicas construtivas. O estabelecimento dos fazendeiros na capital, aliado a forte imigração externa ${ }^{9}$, provocou uma grande transformação urbana na cidade. (Fig. 9)

Em 1872, promoveu-se o primeiro grande loteamento planejado, concomitantemente ao advento da ferrovia com ruas retas e amplos lotes retangulares onde antes era a chácara Mauá, no antigo Campo Redondo, o nome escolhido para o bairro denota claramente as aspirações da elite emergente: Campos Elíseos (uma alusão à cidade de Paris).

A proximidade com a Estação da Luz, uma das principais referências arquitetônicas da capital paulista no período, foi um dos fatores determinantes para a escolha do sítio. O recém inaugurado loteamento contava com a primeira linha de bondes paulistana, permitindo o deslocamento dos moradores valendose do transporte coletivo.

Na gestão de João Teodoro Xavier (1872 a 1875) a cidade passa por melhoramentos gerais como pavimentação das calçadas e ruas da cidade, arborização de algumas ruas e remodelação de praças como o Jardim Público, o Largo Sete de Abril e a criação da llha dos Amores numa faixa de terra da várzea do Tamanduateí destinada ao lazer.

O sucesso desse empreendimento incentivou a transformação de outras antigas chácaras paulistanas, que passam a ser loteadas de forma empírica e desordenada,

${ }^{9}$ São Paulo passa de 24.000 habitantes em 1872, para 130.775 habitantes em 1893. 
Fig. 9. Planta da região central de São Paulo (1968).

São Paulo confirma sua posição estratégica de entreposto e centro distribuidor de mercadorias. Evidencia-se a ocupação das áreas lindeiras aos caminhos de entrada e saída de mercadorias. Nota-se que o grande foco de desenvolvimento margeia a região Oeste, já se caracterizando como uma tendência de expansão.

Fonte: Biblioteca Mário de Andrade, Setor de Mapoteca.

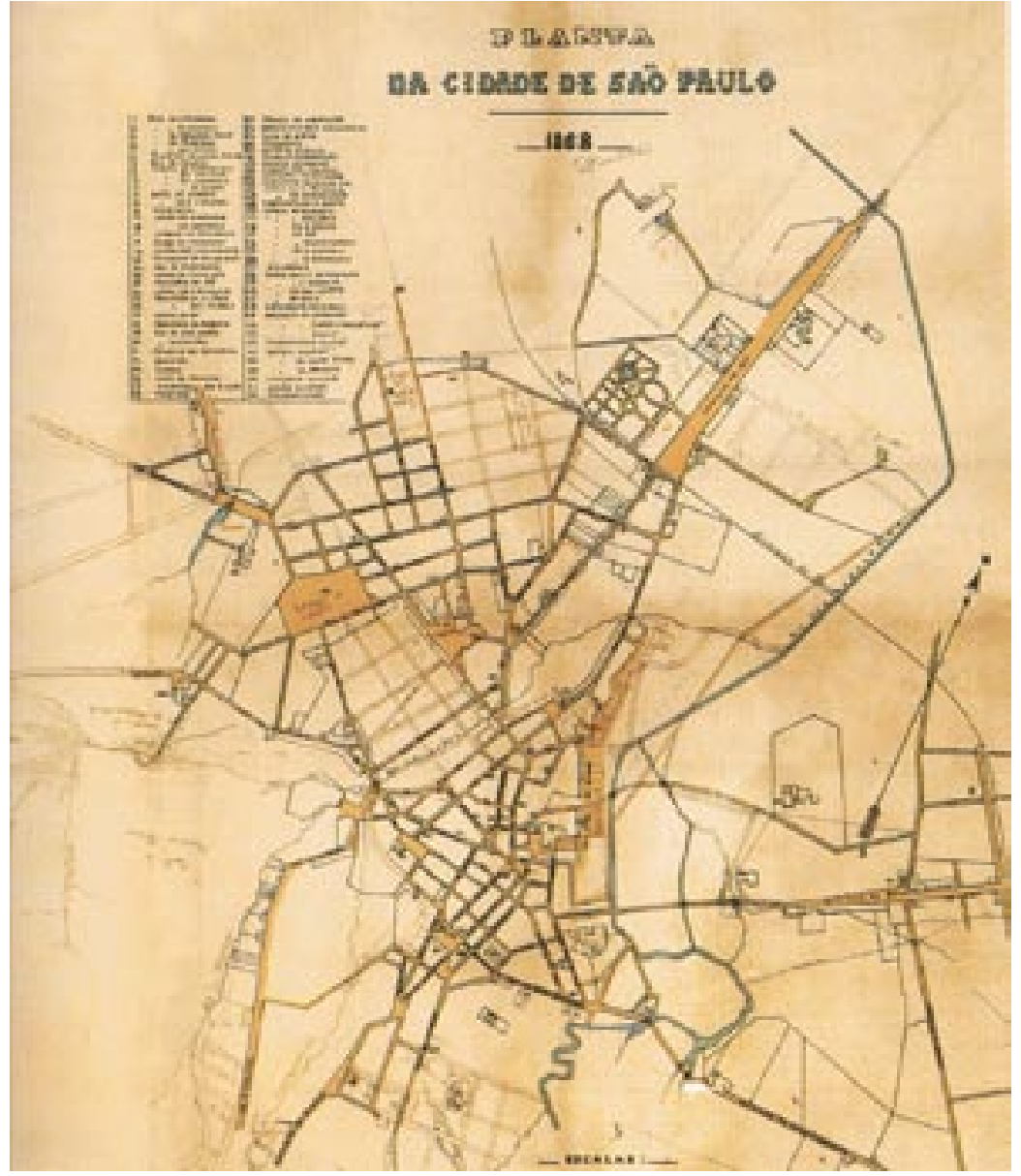

inicialmente ao redor da região, provocando um surto de urbanização excessivamente fragmentado que a médio prazo criou uma malha urbana descontínua causando permanentes problemas de tráfego viário e de identidade urbana; e que infelizmente converteu-se desde então no padrão inquestionado da expansão urbana da cidade.

"Assim, uma a uma, as antigas chácaras, tão apreciadas pelos viajantes que aqui passaram na primeira metade do século, começam a ser loteadas... Na região norte da cidade, além da chácara Mauá, são loteadas a as chácaras Miguel Carlos e do Bom Retiro; para leste a da Figueira... Mais afastados, os sítios do 
Coaguaçu, onde seria aberta a Avenida Paulista, o Tapanhoim, o Ipiranga, a Casa Verde, a Freguesia do Ó, o Anastácio e a freguesia da Penha."10

Para abrir estes loteamentos os proprietários deveriam seguir o Código de Posturas do Município, em vigor desde 1876. ${ }^{11}$ No Loteamento do bairro de Higienópolis, que começou a ser implantado em 1893, não estava prevista a construção de praças. Os moradores do loteamento podiam contar apenas com o "terraço Saint Gemain", pequeno mirante construído na Avenida Higienópolis existente até hoje ${ }^{12}$. Assim a cidade vai se definindo e se setorizando, com características específicas para cada região: bairros "elegantes", populares e centro. Em 1890 é aberta a Av. Paulista, sendo reservada a área de uma mata para a construção de um parque. Em 1892 são inaugurados o Parque Villon (atual Parque Siqueira Campos, mais conhecido como Trianon) e o Trianon propriamente dito, que era o mirante que foi demolido nos anos 50, situado no atual prédio do MASP.

Enquanto as chácaras periféricas a malha urbana foram se retalhando rapidamente, a área central da cidade também sofreu modificações. As edificações de taipa passaram a ser substituídas por prédios de tijolos. Surgem as casas urbanas com um novo tipo de implantação, afastadas dos vizinhos e com jardins laterais. No final do século $X I X$ e início do século $X X$ as edificações, principalmente aquelas destinadas a classes mais abastadas, se destacam dos limites dos lotes, como na Av. Paulista e nos bairros de Higienópolis e Campos Elíseos, misturando as tradições de chácaras às residências urbanas e trazendo para a cidade os hábitos dos jardins particulares. (Fig. 10)

Outros loteamentos de morfologia semelhante às quadrículas quase regulares superpostas, vão se implantando aleatoriamente ao relevo acidentado paulistano, margeando antigos caminhos, rios e estradas, configurando um território permeado de vazios.
${ }^{10}$ Toledo, Benedito Lima de. Três cidades em um século, 1983, pág. 68.

${ }^{11}$ Este código exigia que as ruas fossem retas e planas e com 13,22 metros de largura, salvo algum obstáculo e, as eventuais praças e largos - que não eram obrigatórias suas implantações - deveriam ser quadrados, tanto quanto o terreno permitisse.

${ }^{12} \mathrm{~A}$ Praça Buenos Aires foi construída por uma iniciativa da prefeitura, que comprou uma quadra e implantou a praça entre 1913 e 1916. 
Assim, a cidade passa a deter a maior taxa de crescimento econômico, industrial e populacional do país, e ao vertiginoso crescimento da capital alia-se um processo de descentralização e de segregação social, consolidando alguns bairros operários e outros ocupados pela burguesia. São Paulo iniciava sua metropolização ${ }^{13}$.

O final deste período tem como marco o ano de 1930, quando se rompe a estrutura político-econômica baseada na produção agrícola e inicia-se uma política de industrialização que alterou a antiga estrutura territorial e urbana marcada pelas áreas regionais de produção voltadas para o mercado externo. $O$ Brasil entra num terceiro período (1930-1948) no qual a estrutura

Fig. 10. Planta da região central de São Paulo (1897) São Paulo já estabelecera um contato real com seu primeiro anel periférico, consolidando um vasto território ocupado, com poucos vazios.

Fonte: Biblioteca Mario de Andrade - Setor de Mapoteca.

${ }^{13}$ Entre 1872 e 1920, sua população salta de 31.385

- a décima entre as capitais brasileiras, para 579.003 habitantes - só menor que a capital federal: o Rio de Janeiro.

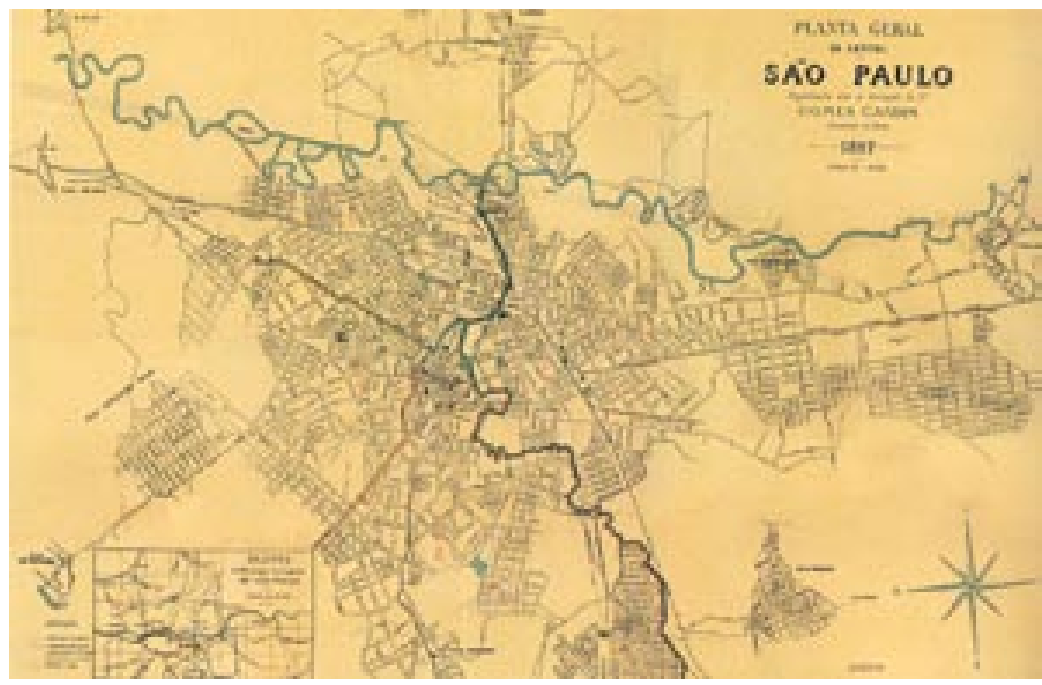

produtiva e o pacto de poder estabelecido no ciclo anterior entre a burguesia comercial e a classe de latifundiários semifeudais não foi capaz de suportar os efeitos da crise externa.

As duas décadas seguintes, coincidentes com o pós-guerra trazem o apogeu e a queda do sistema ferroviário. A economia paulista, cada vez mais aquecida pelas atividades industriais, caminha paralela a uma máxima expansão territorial das ferrovias. Mas a mentalidade imediatista de vincular o sistema 
ferroviário exclusivamente ao interesse dos cafeicultores ajudou a inviabilizar sua existência após este ciclo, que já havia sofrido um duro golpe com as crises dos anos 30 e o fechamento do comércio internacional decorrente da II Guerra Mundial, tendo ambos dificultado a obtenção de materiais para a manutenção das linhas e a renovação dos trens.

Após uma fase de investimento e expansão, com um mercado interno de demanda efetiva reduzida, não tardou o período depressivo (1962-1965), a desaceleração do crescimento chegou a ponto da produção industrial declinar em termos absolutos em 1965. Os investimentos governamentais decresceram, mas ainda assim foram suficientes para prosseguir na construção da rede rodoviária para a articulação do mercado nacional. A malha ferroviária existente era condizente com a antiga estrutura econômica das cidades, com linhas convergindo para as principais capitais litorâneas ${ }^{14}$, mas essa estrutura ferroviária não se prestava para os novos fluxos internos e o trem foi, aos poucos, sendo substituído pelo caminhão.

A cidade estava em franca expansão demográfica, atendida pela expansão rarefeita de seu tecido, ocupado de maneira aleatória e nada planejada; onde o traçado viário da cidade decorreu do sistema fundiário de parcelamento do solo, sempre a favor da especulação e interesses particulares.

Apesar de ter existido uma política de melhoramentos na virada para o século $X X$, principalmente na gestão João Teodoro e terem ocorrido embelezamentos pontuais nas décadas seguintes, somente após 1930 surgiram trabalhos que buscaram visualizar a cidade como um todo, a ser organizado segundo diretrizes e interesses urbanísticos genéricos. Destaca-se então, o Plano de Avenidas, de autoria do engenheiro e depois prefeito nomeado Francisco Prestes Maia, propondo um desafogamento do fluxo viário no centro da cidade e uma expansão de seus tentáculos, com ênfase em sistema de transportes de superfície, em detrimento de uma possível solução metroviária subterrânea,

\footnotetext{
${ }^{14}$ praças do comércio de importação e exportação dos ciclos anteriores
} 
com implantação tardia, na década de 70 , e um evidente prejuízo para os sistemas de transporte de massas.

O Plano de Avenidas de Prestes Maia (1930) traduziu os problemas urbanos e os conceitos urbanísticos para enfrentar os problemas daquele momento; o plano propunha uma clara sistematização da malha viária criando uma nova estrutura para o centro. Baseou-se sobretudo na utilização de um modelo geométrico que conjugava uma avenida perimetral a um conjunto de avenidas radiais, distribuidoras, que deveriam garantir a articulação do centro com os bairros centrais. A proposta sobrepunha-se à malha ferroviária sem se articular com ela, reforçando e ampliando as cicatrizes e barreiras no interior do tecido urbano.

Esse conjunto de intervenções, gradualmente implantada, possibilitou na década de 50 uma radical expansão do modelo rodoviário em São Paulo. Foi nesse contexto de prioridade absoluta às demandas da circulação viária e decadência do transporte ferroviário, substituído pelo transporte rodoviário, que os bairros centrais começaram, a partir dos anos 60, sem ter resolvido suas crônicas questões de acessibilidade, a sofrer um processo de degradação urbana. $\mathrm{Na}$ verdade o processo de isolamento e decadência já havia atingido níveis elevados, dada a absoluta prioridade oferecida a macroacessibilidade metropolitana em detrimento da microacessibilidade local.

A crescente urbanização que acompanhou esse processo de industrialização fez com que fossem desaparecendo as zonas rurais que separavam a capital de sua circunvizinhança, dando lugar a uma faixa contínua de indústrias e habitações, extravasando os limites municipais.

No final da década de 1960 as carências de infraestrutura e equipamentos urbanos eram preocupantes. A cidade viu sua população multiplicar seis vezes e sua área urbanizada quadruplicar, sem que se elaborasse qualquer plano para áreas verdes de convívio. Já neste tempo vigorava a lei de doação 
de uma porcentagem de glebas loteadas, dentro do perímetro urbano, para a implantação de áreas verdes, porém, a prefeitura não foi capaz de fiscalizar essa real doação e impedir, na maioria dos casos a invasão destas "'áreas verdes" por favelas.

Assim, esse violento processo de expansão urbana de priorização do sistema viário em detrimento de qualquer plano de implantação de áreas verdes de recreação, deixou escapar que a cidade garantisse uma reserva de áreas para a posterior implantação de um sistema de áreas livres que garantisse à população uma melhor qualidade de vida urbana. 
2. A Cidade de São Paulo 


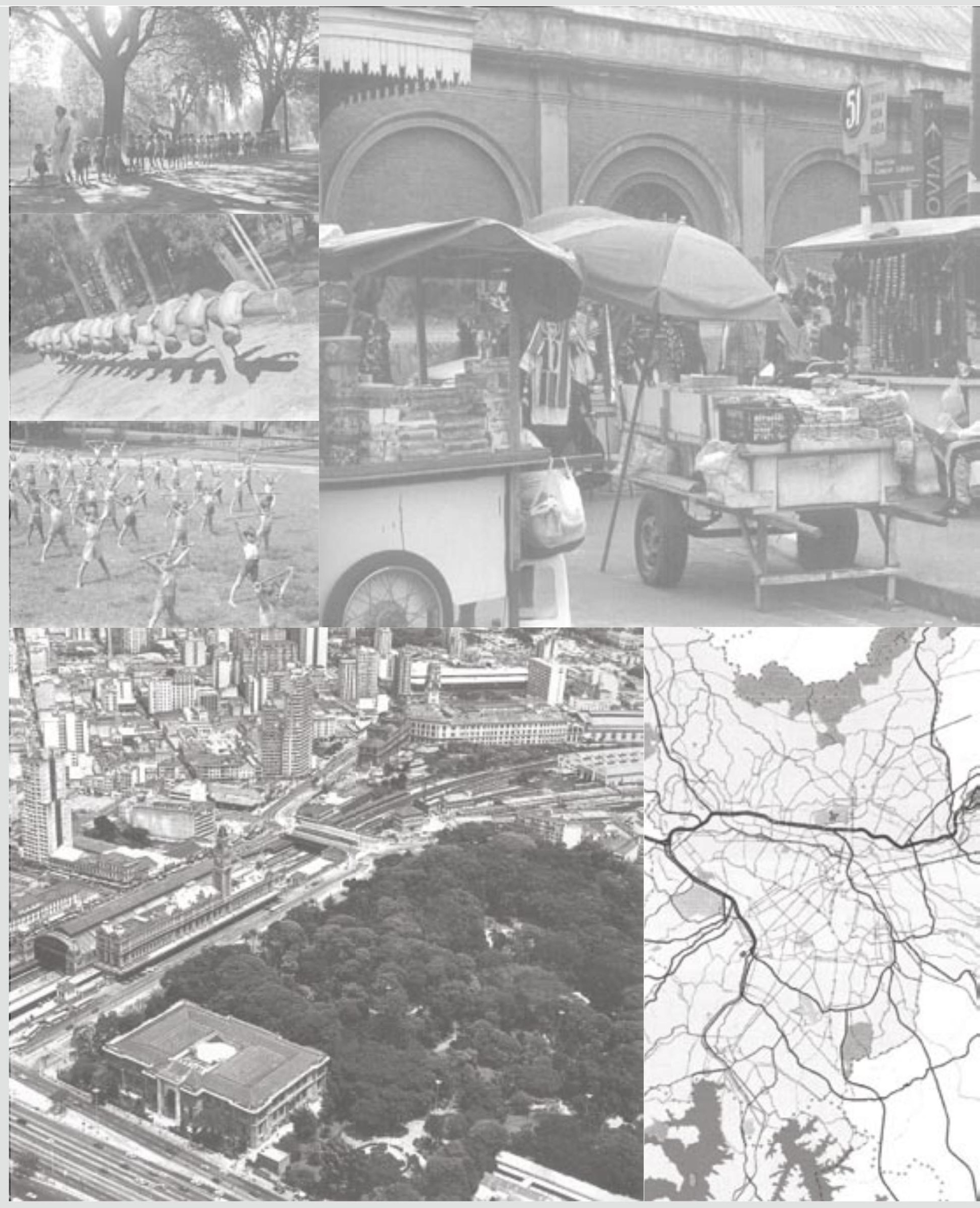




\section{Capítulo 03 \\ A CONFORMAÇÃO DO SISTEMA DE ESPAÇOS \\ LIVRES PÚBLICOS}

Este capítulo tem por objetivo compreender o processo de formação e a atual situação do Sistema de Espaços Livres de São Paulo.

Parte-se do entendimento da incorporação do "lazer" no "programa de necessidades" dos espaços livres públicos e de sua relação com a efetivação do tempo livre do trabalhador na sociedade industrial.

A partir daí, faz-se um relato da produção e implantação de espaços livres públicos da cidade até os dias de hoje; para então adentrar-se no atual Sistema de Espaços Públicos de São Paulo. 
3. A Conformação do Sistema de Espaços Livres Públicos 


\section{O l azer orga $\mathrm{n}$ iz a do $\mathrm{n}$ a e fe t i v a ço do te m p livre d o t r a b a I h a d o r}

O século XX presenciou o surgimento de uma nova fase do capitalismo industrial que modificou profundamente a estrutura da sociedade e com ela todo o padrão da vida cotidiana.

As transformações provocadas pela Segunda Revolução Industrial, iniciada na Europa por volta de 1870, foram tão prodigiosas quanto revolucionárias nos resultados sobre a vida cotidiana e na perspectiva das populações. A introdução de processos científicos permitiu um notável avanço tecnológico acompanhado do desenvolvimento de novas formas e organização capitalista, tendo a grande indústria como pilar de um novo processo racionalizado e unificado de produção. Essa radical mudança transformou o mundo do trabalho, consolidando as bases de uma sociedade urbano-industrial que redefiniu toda a estrutura social do século seguinte.

A intensificação do ritmo de produção, dentro de um cenário que busca a eficiência e produtividade, transformou o homem em um apêndice da máquina, causando cada vez mais seu distanciamento de valores característicos como a ludicidade e o entretenimento. Os resultados desse processo foram os elevados níveis de stress e fadiga jamais vistos antes; vindo a contribuir diretamente para o surgimento do lazer em decorrência da organização do tempo livre, ainda que num primeiro momento fosse encarado apenas como um descanso após a jornada de trabalho.

Em meio a todas essas tensões produzidas pelo capitalismo em expansão, gerando uma predatória e acelerada expansão das cidades industriais, a dinâmica da cidade condicionou-se à dinâmica da indústria.

As congestionadas cidades reduto das então burguesias ligadas à primeira Revolução Industrial, constituíram um 
impressionante símbolo exterior de um mundo em transformação. Um mundo que glorificou o trabalho, ou como observa Hannah Arendt, "um mundo que resultou na transformação efetiva de toda a sociedade em sociedade operária“..$^{15}$

Esse processo de concentração populacional nas cidades européias foi o mais impressionante fenômeno social. O êxodo populacional às cidades que se industrializaram modificou todo o sistema político existente. As populações se concentraram em áreas tentaculares exigindo novas demandas sociais.

Incentivado pelo imperialismo em expansão, o mercado de massas ampliou-se globalmente e a cultura de massas resultante, fomentou a indústria dos lazeres; sendo esta "democratizada" e inserida na teia de consumo que caracterizou o novo estilo de vida urbano-industrial.

Considerado antes como prerrogativa de classe, o lazer se transformou em um fenômeno de massa amparado pelos meios de comunicação, fugindo assim do controle das instituições sociais conservadoras - esse processo tornou-se fundamental para a politização do tempo livre pela classe trabalhadora.

Logo, a visão técnica introduziu políticas de intervenção na cidade através de ações de saneamento e saúde púbica, atingindo sobretudo as moradias populares. A percepção política das classes proletárias enquanto força de trabalho, geradora de conflitos e incertezas, demandou um novo campo de debates no universo político do século XIX que adentrou pelo século $X X$; afinal, sua presença nas cidades era uma realidade inequívoca a exigir uma nova postura frente aos problemas sociais emergentes.

Por outro lado, os problemas ambientais resultantes desse processo industrial, exigiam uma solução imediata, face à urgente necessidade de controlar por motivos políticos e econômicos os elevados índices de enfermidades existentes na cidade. Foi diante desse predatório processo de urbanização que se propôs a "medicalização" do ambiente, oferecido a princípio como um

${ }^{15}$ ARENDT, Hanna. A condição Humana. 1981, pág. 12 

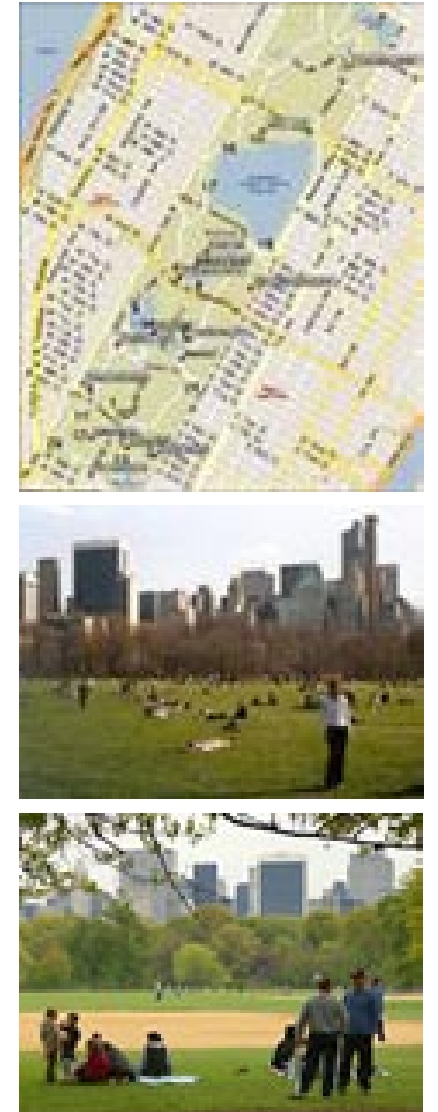

Fig. 11,12 e 13. Central Park, Nova York.

Planta de localização e apropriação cotidiana de seus usuários.

Fotos: MEIRELLES, Daniel.

${ }^{16}$ destaco a importante
contribuição do movimento
higienista e seu ideal
de salubridade com
ações disciplinadoras e
racionalizadoras no espaço
urbano.
17 apud. Segawa, Hugo.
Construção de ordens; um
aspecto da arquitetura no

Brasil, 1987,pág. 35 projeto de reforma social, sendo posteriormente transformado em um extenso programa de reforma sanitária vindo a motivar intervenções urbanas. ${ }^{16}$

Baseado no discurso médico, no qual a cidade assume um papel de objeto, o ideal de salubridade prescreverá um controle social do espaço urbano, sugerindo medidas de proteção ou compensação aos males decorrentes do industrialismo. Nesse contexto, a noção de higiene pública de Michel Foucault fundamentará o "controle político-científico deste meio"17, tornando a cidade um campo de trabalho privilegiado para a medicina social. Partindo desses pressupostos criou-se no século XIX o Parque Urbano Público enquanto um importante espaço higiênico e "pulmão" da cidade. (Fig. 11, 12 e 13)

Reconhecida pela ciência, a higiene social integrou-se ao urbanismo qualificando o parque público como importante condicionante do futuro comportamento social do trabalhador. Os reformadores sociais contribuíram ativamente ao reivindicar uma nova ordem urbana que incluísse a dotação de áreas verdes e de um "cenário natural" que servisse como antídoto aos rigores da sociedade de trabalho e face à ameaça de uma urbanização desenfreada. Neste contexto surgem novas exigências e novos programas de necessidades contendo elementos que oferecessem alívio às tensões urbanas através de um lazer organizado, ou planejado, com objetivos reformadores dentro dos padrões morais existentes.

Ao estabelecer-se a importância dos parques para os problemas de saúde pública - do corpo e da mente - reduzindo questões estéticas a um plano secundário, inaugurou-se uma nova e primordial função urbana: a de importante espaço funcional a serviço do tempo livre. Os parques públicos, alçados a essa nova condição funcional, passaram a ganhar destaque no processo de urbanização em curso.

O urbanista Lewis Munford ao preconizar nas sociedades urbanas o equilibrado ambiente comunitário das cidades antigas, 
criticava o urbanismo capitalista pelo seu uso indiscriminado de ruas largas, por tomar o lugar do quintal e da praça protegida da cidade medieval, ou da praça aberta e do parque da ordem barroca, tal é a importância dada a circulação. ${ }^{18}$ Esse fato já havia sido observado por Marx ao apontar o "aperfeiçoamento progressivo" nos "meios e comunicação e transporte" no contexto da urbanização capitalista como condição necessária à reprodução do capital. A lógica orientadora do crescimento urbano foi, e de certa maneira ainda é, geradora do benefício privado superposto a qualquer interesse ou benefício social como prioridade. Reverter esse quadro anti-social sem recair nos antigos clichês, favorecendo a conviviabilidade e o lúdico será fundamental para um novo estabelecimento humano nas cidades, onde os espaços públicos têm um papel social, freqüentemente negligenciado pelo poder público. Essa visão em busca de um urbanismo menos utilitário e mais humano é uma premissa básica para se resgatar a função social da cidade.

Porém essa visão só foi efetivamente tematizada com o surgimento do urbanismo moderno, como uma necessidade de responder ao impasse civilizatório enfrentado pela degradação das cidades industriais, oferecendo modelos entre várias correntes de pensamento, tendo como âncora a higiene e a salubridade.

Dentre essas iniciativas destaca-se a de Ebeneezer Howard apresentada em seu livro Cidades-Jardins para o Amanhã, escrito em 1902. Howard propõe resgatar as ricas tradições culturais inglesas ligadas ao naturalismo e seus valores políticos e sociais, então ofuscados pelo industrialismo negligente e suas práticas especulativas. Numa inversão de valores, ele propõe uma radical alteração no processo fundiário existente ao dispor o solo urbano em caráter corporativo, sociabilizando-o. Distribuída em setores independentes em relação aos equipamentos comunitários, inclusive os de lazer, as cidades-jardins inovaram

${ }^{18}$ Munford, Lewis. In: CHOAY, Françoise. O Urbanismo. 1979. 
Fig. 14 e 15. Bairro jardim de 1919 com predominância de ruas sinuosas com grande espaço para praças e jardins. Vista da Rua Guadelupe, entre a Rua Estados Unido e a Av. Brasil. ao criar o embrião daquilo que ficou conhecido como unidades de vizinhança.

No Brasil, este modelo urbanístico foi parcialmente implantado nos bairros jardins paulistanos - Jardim Europa, Jardim América, Pacaembu, Alto da Lapa, Alto de Pinheiros, fruto da iniciativa privada, destinando-se, porém, às classes altas, num contraste com a preconizada função social estabelecida por Howard.
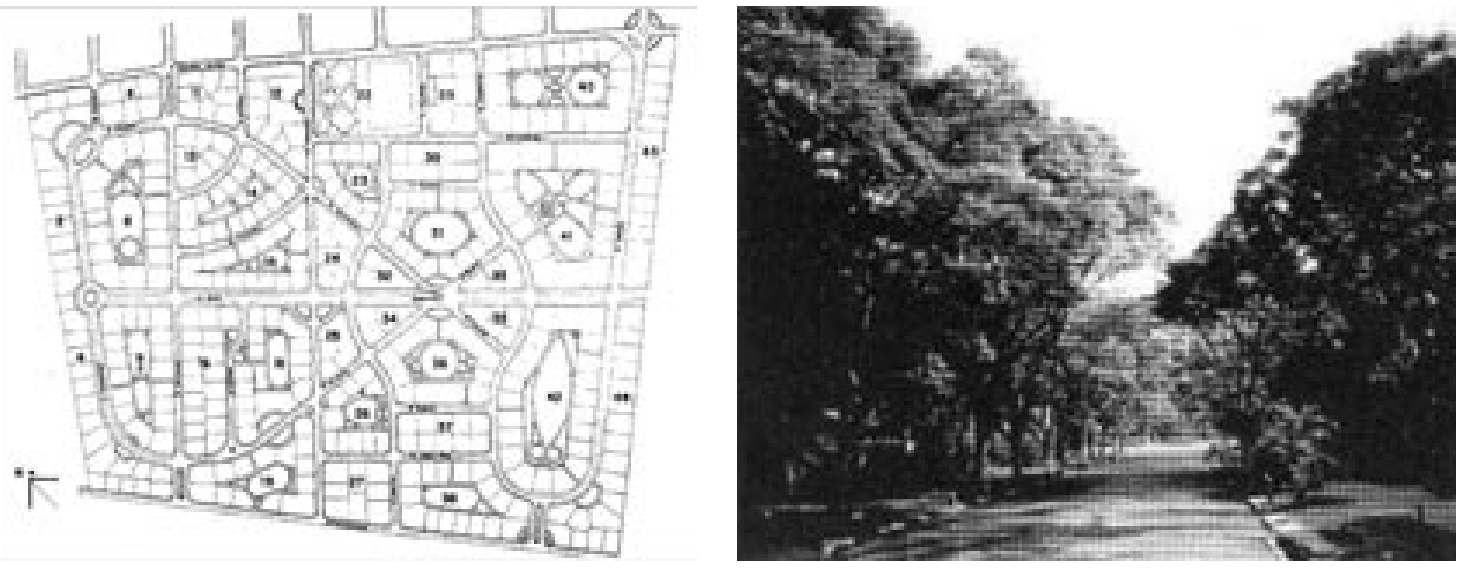

Fig. 16 Vista aérea do Jardim América

Fonte: Conselho de Defesa do Patrimônio Histórico, Arqueológico, Artístico e Turístico - CONDEPHAAT - Setor de Fotografia.

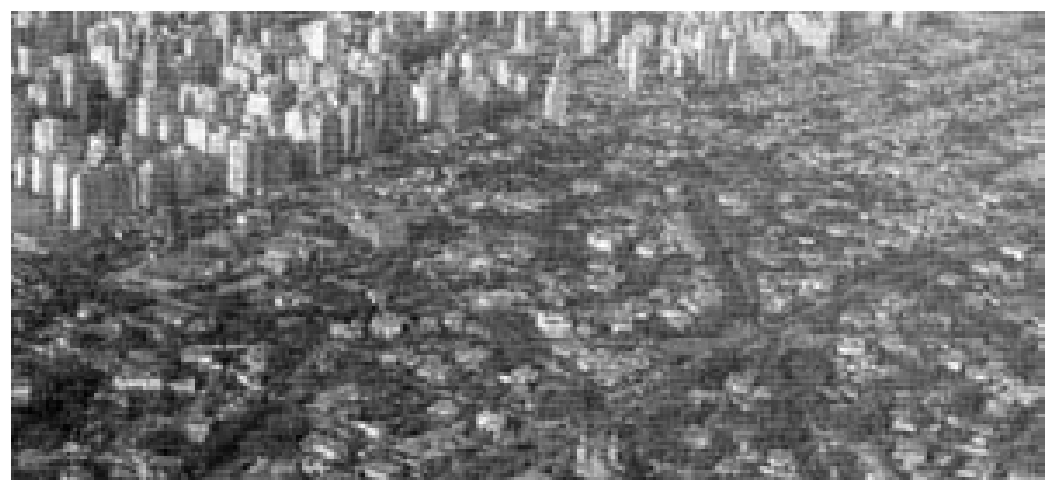

Uma outra vertente do urbanismo moderno caminhou com Tony Garnier e sua proposta de organização das cidades industriais, influenciando marcadamente o urbanismo racionalista da primeira metade do século XX. Em seu livro "Uma cidade industrial - estudos para a construção de cidades", publicado em 1917, Garnier trata dos fundamentos da cidade racionalizada 
e planejada, base do urbanismo moderno. Afinado com os pressupostos da higiene do trabalho, seu rígido zoneamento urbano destina um setor público ao lazer e à prática de esportes. Considerada a primeira manifestação do urbanismo progressista, segundo a terminologia de Françoise Choay, a proposta de Garnier antecipa valores que só seriam propostos na Carta de Atenas (1933) que balizaram experiências urbanas da primeira metade do século $X X$.

Ao propor condições de vida ainda não possíveis de se estabelecer nas cidades existentes, as utópicas iniciativas apresentadas tanto no empirismo inglês de Howard, quanto no racionalismo francês de Garnier, tentam oferecer uma resposta particular a uma situação insustentável das cidades reféns da livre iniciativa e seus processos especulativos com o solo urbano. Ambos propõem uma relação ética com a função urbana tentando estancar a crise social e política da cidade ao oferecerem modelos inibidores da precariedade existente. Os equipamentos de lazer comunitário em ambas as propostas receberam um tratamento a altura da nova condição a serviço do tempo livre e do bem estar coletivo.

Mas, a importante e decisiva contribuição para a organização da cidade moderna em termos de sociabilização do bem estar decorrente dos avanços técnicos do período, veio através do $4^{\circ}$ CIAM (Congresso Internacional de Arquitetura Moderna) realizado em Atenas, cujo tema "Cidade Funcional" lançou os postulados do urbanismo racionalista. O resultado das discussões gerou o documento conhecido como a Carta de Atenas, publicada em 1933 por Le Corbusier, preconizando as chaves do urbanismo nas funções de habitar, trabalhar, recrearse e circular. O lazer ganha assim o status de importante função urbana dada a ampliação do tempo livre do trabalhador. Críticas a parte quanto ao urbanismo funcionalista e à arquitetura internacional, a importância que o mesmo confere às funções urbanas associado a necessidades básicas, entre elas o lazer, é 
inegável e torna-se um divisor de águas na consolidação dessa "nova" função dos espaços públicos.

Assim, ao reconhecer-se o tempo livre como algo necessário ao desempenho de todas as classes sob o aspecto econômico, social, cultural e político, abre-se um amplo leque de possibilidades de organização do planejamento das atividades de lazer dentro das chamadas políticas urbanas.

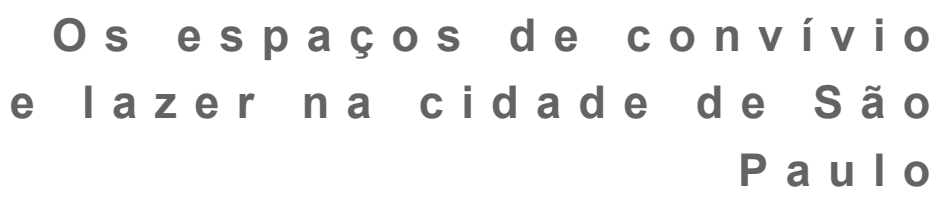

Frente à problemática implantada com todo o processo de urbanização e industrialização apresentada no capítulo 1, a produção de espaços públicos de lazer em São Paulo obedeceu a uma dinâmica própria face às contingências histórico-culturais oriundas desse processo contraditório de desenvolvimento urbano e social, e a todas as implicações daí decorrentes em termos de apropriação desses espaços pela população.

Palco dos devaneios burgueses nas consolidadas cidades européias, os espaços públicos de lazer eram um privilégio na acanhada São Paulo da primeira metade do século XIX, exceto pelo venerável Jardim Público (atual Jardim da Luz) criado pelo aviso régio de 1798 e aberto ao público em 1825, com seu uso ora voltado para o lazer, ora para a pesquisa botânica.

O surgimento dos espaços em São Paulo estava na maioria das vezes intimamente ligado ao entorno das igrejas e capelas, daí originando sua popular denominação de largo, pátio ou campo. Esses espaços livres articulavam-se à modesta trama viária da cidade, dando lugar ao lazer e ao encontro comunitário, com seus eventos religiosos envolvendo a provinciana e pouco exigente sociedade paulistana da época. 
A apropriação dos largos e dos demais espaços lúdicos só se modificou no final do século XIX, à medida que a cidade se transformou em um importante entreposto comercial e de negócios afirmando sua posição de rica "capital do café" e em seguida como uma emergente cidade industrial. Esse período ficou conhecido como a "refundação da cidade", por seu impulso modernizador, ensejando iniciativas disciplinadoras da ordem urbana sob o conceito de salubridade e embelezamento.

Ao mesmo tempo em que esse "sopro renovador" ensejava mudanças substanciais na paisagem urbana da "velha cidade", expressava profundas transformações sociais diante das novas possibilidades de vida que o fenômeno da industrialização proporcionava. Alteraram-se valores e ritmos de vida, sobretudo religiosos, típicos das sociedades tradicionais e pré-industriais, dando lugar às novas relações sociais baseadas no trabalho assalariado. Foi nesse momento, na virada do século XIX para o século XX, que se deu o contínuo esvaziamento da presença religiosa na vida cotidiana do paulistano, com profundos reflexos na sua prática lúdica.

O aparecimento de modalidades de lazer urbano, as mais variadas, como o cinema, a natação e a canoagem nos novos clubes à beira dos rios Tietê e Pinheiros, o "footing" na área central e os jogos esportivos, impuseram novos hábitos à população, ávida para acompanhar o ritmo das transformações urbanas. Desde cedo o esporte identificou-se com o dinamismo da vida urbana que surgia em São Paulo. Sua prática, no entanto, ficou reservada aos clubes e demais áreas privadas da cidade, sendo timidamente oferecido nos novos parques públicos, que por sua vez tiveram suas origens, na maioria das vezes, na necessidade de preservar os mananciais e às questões de ligadas à higiene pública.

Os largos, pátios e praças da cidade continuaram seguindo a estética européia com um tratamento paisagístico adequado aos interesses e anseios da classe dominante, dando forma 
também a uma "compartimentação" social do espaço urbano.

Assim, o surgimento das classes proletárias em São Paulo ocorreu em um clima de estranhamento e insegurança, gerando um quadro sócio-político instável e altamente repressivo por parte de uma sociedade que estava preocupada em delimitar espaços de convivência que diferenciassem o status da elite. O encontro dos novos atores sociais no cenário urbano com seus interesses e visões distintas e antagônicas aos moldes da época, conferiu diferentes possibilidades de apropriação dos espaços públicos.

A busca da diferenciação social ultrapassou os domínios do público e do privado, estabelecendo uma "geografia de exclusão" e segregação social. Esse recorte discriminatório produziu uma linha divisória visível, o Rio Tamanduateí, delimitando o "lado de lá", região operária, em contraposição ao "lado de cá", a cidade, onde estavam as elites. Como resultado estabeleceu-se um espaço quase privado, circunscrito a área central da cidade com a implantação de um urbanismo embelezador, com suas praças, avenidas e boulevares afinados com um ideal de modernidade importado da Europa.
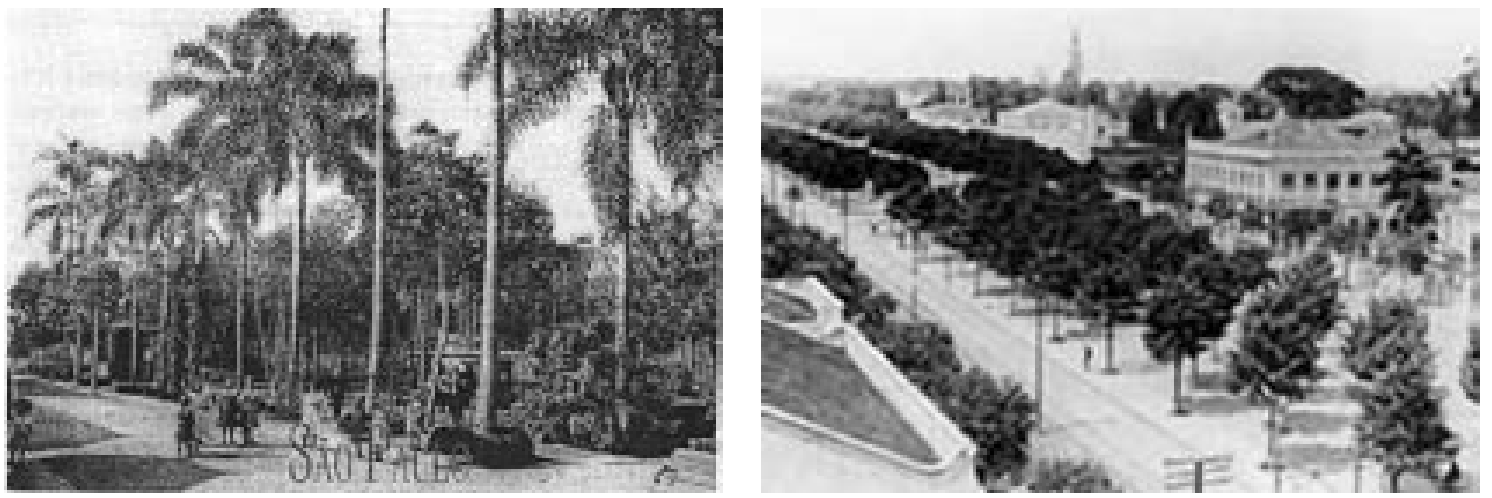

Fig. 17 e 18. Fotos do Jardim da Luz, à esquerda, e do boulevard da Av. Tiradentes.

Fonte: Conselho de Defesa do Patrimônio Histórico, Arqueológico, Artístico e Turístico - CONDEPHAAT - Setor de Fotografia
Nesse contexto, não havia lugar para um lazer que não se identificasse com os preceitos morais burgueses e seus códigos de bom comportamento, levando a uma conseqüente territorialização dos hábitos de lazer.

Porém, na outra extremidade da cidade, localizado do lado de lá do rio, encontrava-se uma outra realidade física e social. 
Foi no mundo onde vivia e trabalhava a classe operária que se estabeleceram hábitos de lazer, por força das circunstâncias sociais, que alcançaram uma outra ordem de valor. Desse território imposto e circunscrito em torno das fábricas, à margem da visão higienista da época, irradiou-se um processo de interação social único e independente gerado pela proximidade e pela conjunção de interesses de classe. O resultado foi a tendência de se politizar as ações coletivas, pondo em prática a exaltação da identidade operária.

As associações operárias buscaram a formação da consciência de classe do operariado, ao mesmo tempo em que atenderam às necessidades de lazer, divertindo e sociabilizando a classe trabalhadora que não tinha acesso aos poucos equipamentos de lazer que a sociedade burguesa produzia voltados aos interesses das classes mais privilegiadas. ${ }^{19}$ Os encontros de lazer promovidos, intitulados festivais, eram verdadeiras festas operárias, consistiam em passeios, excursões, teatro social, competições esportivas, piqueniques e encontros diversos, sempre motivados pela busca da consciência e solidariedade proletárias. (Fig. 19 e 20)

O lazer popular de São Paulo teve dessa forma sua origem vinculada aos movimentos sociais de natureza política existentes nos primórdios do industrialismo nacional. Foi nesse período que se deu a proletarização do esporte frente às tentativas de desmobilização política das associações operárias.

O esporte foi uma exportação cultural inglesa de um padrão de lazer que se tornou globalizado em decorrência da própria expansão ultramarina. Sua popularização a partir dos clubes e campos de várzea espalhados pela periferia da cidade, forjou a consolidação do futebol como fenômeno de massa em São Paulo ainda na década de 1920. Foi também nos descampados da várzea do Carmo que o futebol em sua acepção mais popular, ganhou a denominação de "futebol de várzea", após sua apropriação pelas camadas mais populares. Por outro lado,

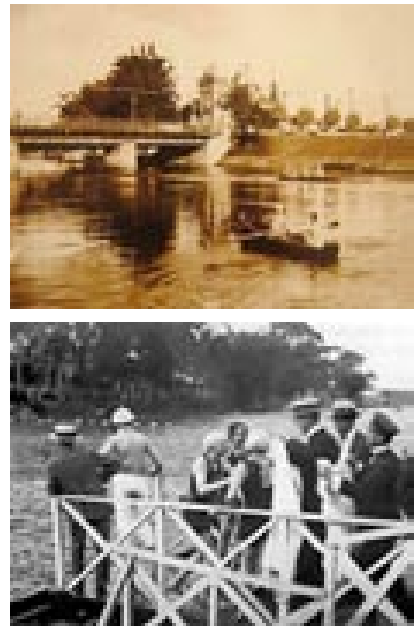

Fig. 19 e 20. Clube de Regatas Tietê.

Fonte: Conselho de Defesa do Patrimônio Histórico,

Arqueológico, Artístico e Turístico - CONDEPHAAT - Setor de Fotografia

${ }^{19}$ O lazer operário foi estigmatizado pela classe burguesa que o enquadrou pejorativamente, sinonimizando-o com o ócio. Considerado caso de polícia, o lazer das camadas populares desenvolvia-se à sombra das milícias de quarteirão. 
foi nesta mesma época quando a cidade fabril perceberá sua carência de espaços públicos adequados à prática esportiva e recreativa.

As providências administrativas de clubes e governo para dotar a cidade de uma infra-estrutura em equipamentos esportivos não acompanharam a febre das "peladas" que pipocavam nos vários cantos da cidade. Assim, o esporte desde sua formação como elemento de lazer e recreação em São Paulo, conviveu com a carência e intimidação, onde sua improvisação nas ruas e praças da cidade suscitou na figuração do perigo velado e iminente presente na multidão em constante correria pelas ruas.

Uma outra forma menos comum de lazer organizado para as massas, se deu com base em esporádicas ações pontuais no âmbito do planejamento urbano ainda durante o período denominado de República Velha, que antecedeu o governo Vargas (1930-1945). Os mandatários dessa fase, em geral oriundos da burguesia agrária, gerenciavam a cidade em conformidade com os anseios de desejos de uma elite que concebia a cidade como "lugar da desordem social e política" e suas populações como "classes perigosas".

Ao contrário de matrizes européias e norte-americanas, que associavam o pensamento urbanístico à questão social, incorporando com isso novas experiências em termos de equipamentos públicos de lazer, no Brasil a importação de tais modelos implicou em ambigüidades insaciáveis, dada a exclusão social e a recorrente negação da cidadania às classes operárias. Por esse motivo, até o fim da República Velha, a municipalidade não investiu muito na produção de equipamentos públicos de lazer, embora a demanda significativa pelo esporte fosse evidente já na década de 1920, com equipamentos lúdicos existentes provenientes de interesses privados.

Um exemplo disso foi o Velódromo, espécie de estádio ao ar livre construído em 1892. Considerado por Ernani Silva 
Bruno a "célula máter do atletismo paulistano", o espaço foi um presente do Conselheiro Antonio Prado, primeiro prefeito de São Paulo da era Republicana (1899-1911), a seu filho Antonio Prado Junior. Tratava-se de uma raia elíptica medindo $380 \mathrm{~m}$ de comprimento por $8 \mathrm{~m}$ de largura, com um jardim central. Ao redor da raia, foram construídos dois conjuntos de arquibancadas cobertas, uma de frente para a outra. Havia também quadras de tênis e tanques para banhos. Mais tarde, o Velódromo foi arrendado pelo Clube Atlético Paulistano e transformado em um concorrido campinho de futebol.

O surgimento de um outro espaço notável na história do urbanismo paulista, o parque Dom Pedro II, parecia querer alterar esse quadro, pelo menos no projeto. Embora criado a partir da necessidade de melhorar as condições de saneamento da então Várzea do Carmo, vazio urbano entre as margens do Rio Tamanduateí palco da histórica partida de futebol com Charles Muller (1894), a área que já tinha uma forte vocação para a recreação estava fadada a transformar-se em um notável parque voltado ao lazer de massa.

Após diversas tentativas sem sucesso para a implantação de um parque no local, chegando a quase ser vendida à iniciativa privada para a construção de vilas operárias, coube a Raymundo Duprat, segundo prefeito eleito de São Paulo (19111914), convidar o paisagista francês Joseph Antonie Bouvard para a tarefa, o qual após avaliar as condições urbanas, teceu recomendações para a construção de espaços livres, praças públicas, jardins e parques para a cidade. Sua atuação em São Paulo foi considerada diplomática (uma vez que coube a ele conciliar opiniões e levar a bom termo a questão em torno da urbanização do Vale do Anhangabaú, que envolvia diversas tendências em debate), em seu relatório final datado de 15 de maio de 1911, Bouvard antevê o vigoroso aumento da "densidade do aglomerado" urbano e aconselha a construção de três parques: o da Várzea do Carmo - atual Parque Dom 
Pedro, o Anhangabaú, e o terceiro, segundo consta a Praça Buenos Aires: "Lugares de passeio para os habitantes, focos de higiene e de bem estar, necessários à saúde publica, tanto moral quanto física". ${ }^{20}$

Recém empossado no governo municipal, Washington Luiz (1914-1919), defenderá a imediata construção do parque como forma de desapropriar e excluir núcleos marginalizados da população que haviam habitado o local, considerado privilegiado pelos especuladores urbanos. A solução indicada para resolver os problemas da região era a construção de um parque "seguro, saudável e belo". Sua aprovação em 1914, através de uma lei municipal, liberou o início das obras daquele que foi, provavelmente, um dos mais significativos parques urbanos construídos em São Paulo.

Dado como concluído na gestão de Firminiano de Moraes Pinto (1920-1922) que ainda incorporou ao programa do parque a construção de restaurantes, cafés e um pavilhão de festas; o parque Dom Pedro II foi entregue a população em 1922 dentro das comemorações do Centenário da Independência, servindo como importante área de lazer da população do Brás e entorno. No entanto, segundo consta, foi inaugurado sem boa parte das instalações recreativas e esportivas previstas no projeto. Relatos daépoca descrevemairregularidadediscriminatóriaexistentecom a verba pública, tendo os bairros operários sido caprichosamente desprezados por sucessivos mandatários, que não escondiam a clara preferência aos seus interesses de classes. Também se apontam significativos aportes orçamentários destinados as demais obras de embelezamento da cidade, sendo uma de especial valor simbólico para as elites. A conclusão das obras de reforma do Parque da Independência com a sua paisagem conservadora lenotriana, previstas para serem inauguradas na mesma data e servirem de palco as celebrações do Centenário orgulho cívico da elite republicana. 
Já nascendo condenado pela historia, o Parque Dom Pedro II, não viveu muito. Uma serie de intervenções viárias iniciadas a partir de 1929 e em seguida consolidadas pelo Plano de Avenidas colocado em pratica na gestão Prestes Maia (19381945) promoveram uma continua desfiguração do parque, governo a governo, até ser decretado o seu fim nos anos 1960, num processo predatório de ocupação urbana. Processo este que exemplifica a notória contradição existente entre o discurso e a pratica, entre os interesses da maioria da população e da minoria privilegiada e controladora do poder dentro de uma lógica recorrentemente marcada pela segregação espacial e exclusão social. A leitura desse quadro nos permite aferir o panorama de contradições que tem determinado o alcance e a longevidade dos empreendimentos urbanos de caráter social ao longo da historia da cidade.

Com a Revolução de 1930, com a ascendência da era Vargas, tem início uma nova fase com profundas mudanças no panorama político-institucional do país e sob a pressão do Movimento Constitucionalista, pró-constituinte, deflagrado em São Paulo em 1932, será implantada a Constituição de 1934, a segunda da Republica, que previa a proteção social ao trabalhador. Seu Artigo 121 previu medidas que afetaram positivamente a organização do tempo livre do trabalhador, como a jornada de oito horas, repouso semanal e férias anuais remuneradas; reivindicações com um longo histórico de lutas por parte da classe operária.

A política getulista articulou um projeto de modernização do país pautado no industrialismo e na urbanização, nos quais São Paulo figurou como peça fundamental desse sistema. Esse modelo de desenvolvimento aprofundou a concentração industrial na capital, com o conseqüente esvaziamento de outras regiões dotadas de economias tradicionais; ocorrendo grandes migrações campo-cidade, já existentes desde a década de 1920, e agora potencializadas, substituindo a imigração. 
Fig. 21, 22 e 23 Parque Infantil Dom Pedro II (1937).

Fonte: Acervo SAN/DPH/SHC/ PMSP. Foto: Benedito Junqueira

Duarte.
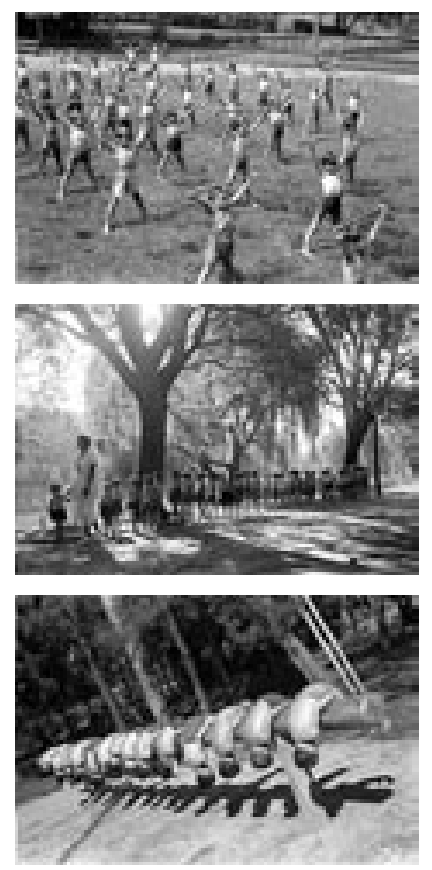

A extensa mobilização desse "exército industrial de reserva", facilitada pelo pesado investimento estatal em obras de infra-estrutura, sobretudo rodoviarista, provocou uma acelerada e predatória urbanização em São Paulo, gerando desequilíbrios profundos. A poderosa e progressista São Paulo aprenderá a conviver lado a lado com quadros crescentes de miséria em suas periferias.

Numa oposição antagônica ao interventor municipal Prestes Maia, tido como incentivador da metrópole, coube a Anhaia Mello um discurso mais humanista. Afeito às experiências de vanguarda, ele propunha estudos em prol de um "sistema geral de recreio" que correspondesse à nova realidade. Preocupações com o adensamento, a deterioração do espaço urbano e a qualidade das áreas livres exigiam, segundo ele, o repensar da função do parque urbano.

Foi nesse contexto, no decorrer de um quadro político instável, em 1930, que surgiram os Parques Infantis. Uma experiência de lazer organizado de impacto social, desenvolvido por personagens ilustres da cultura nacional como: Fernando de Azevedo, Paulo Duarte, Mario de Andrade, Julio de Mesquita, entre outros; induzidos pela busca de soluções concretas para atenuar a grave crise social existente. Mergulhado num otimismo pedagógico que tomou conta desse período, Fernando Azevedo idealizou dotar a cidade de uma completa rede de assistência a jovens e adultos com a implantação de parques equipados para o lazer e convívio. Porém, estes parques atenderam apenas a uma pequena parcela da população, não sendo incorporados ao sistema de espaços livres de lazer da cidade, como havia sido idealizado pelas matrizes. (Fig. 21, 22 e 23)

Enquanto isso, piqueniques no Horto Florestal e nos diversos espaços abertos da Serra da Cantareira, atraíam grande público e, mesmo não sendo uma forma de lazer amplamente disseminada, ir à praia aos domingos tornou-se mais fácil e cada vez mais comum da década de 1950 em diante, com a 
implantação da Via Anchieta, que melhorou o acesso às praias da baixada santista.

Embora não tenha a ver diretamente com o lazer nas áreas livres, mas certamente capaz de retirar-Ihe parte da demanda, temos que considerar a mudança que a televisão, introduzida em 1950, provocou nos costumes gerais e de lazer do paulistano, por ser ela própria um meio de entretenimento.

A década de 1970 consolidou o esporte como forma de convívio e lazer para a cidade, considerado agora uma forma positiva do uso do tempo livre em oposição ao ócio, como já mostramos no início deste capítulo. Nesta época foi implantado o projeto "Ruas de recreio", que contava com profissionais especializados para a coordenação de atividades de lazer. Com altos e baixos, o projeto implantou entre os anos de 1976 e 1978, 182 ruas de lazer pela prefeitura, porém, em 1980 foi desativado.

Os esforços para a promoção do lazer sadio não se ativeram apenas a programas geridos apenas pelas secretarias públicas, que apesar de bem sucedidos, atingiam apenas uma pequena parcela da população. Havia a ambição de atingir as massas e para isto foram criadas em 1975 campanhas nacionais patrocinadas pela União de Bancos e pela Rede Globo, entre elas o Esporte para Todos e o Mexa-se.

A adoção de hábitos de lazer que valorizavam a boa forma física teve seus reflexos nas áreas livres públicas que passaram a prever, a partir da década de 1980, junto ao Departamento de Parques e Áreas Verdes (DEPAVE) de São Paulo, a implantação, sempre que possivel e de acordo com as condições físicas do terreno, de pistas de cooper e de quadras poliesportivas. 


\section{O S iste m a de Es paços L i v r s d e S ão P a l o}

Na cidade de São Paulo hoje, percebe-se uma preocupação com o projeto e manutenção dos espaços livres de circulação e acesso, como ruas e avenidas, enquanto o tratamento de praças, parques e outros espaços livres de edificação foram deixados por algumas décadas (1970-2000) em segundo plano pelas diversas gestões municipais, responsáveis pela normatização, fiscalização, produção e gestão de grande parcela do sistema de espaços livres urbanos.

No cotidiano administrativo é comum a adoção do conceito área verde como um padrão de qualidade urbana que está avaliado por índices genéricos de distribuição. Adotou-se um padrão de $12 \mathrm{~m}^{2}$ por habitante; uma verdadeira mágica estatística que de fato não mede nem mostra a concreta realidade do sistema de espaços livres de cada região da cidade. Porém, esses índices minimizam o papel real do sistema de espaços livres privados na estruturação da totalidade do sistema de espaços livres urbanos, encobrindo eventuais atendimentos de demandas, especialmente nas áreas mais ricas, que são juntamente com as áreas mais centrais, os trechos urbanos mais bem distribuídos com equipamentos e espaços livres públicos, quaisquer que sejam suas finalidades.

A recente produção do sistema urbano de espaços livres tanto pela ação privada quanto pela ação pública, é expressiva e envolve todas as camadas sociais; só que a falta de articulação entre as diversas propostas gerou uma trama urbana individualizada e desconectada.

Para este estudo entende-se então por sistema de espaços livres, não a apenas um conjunto de objetos, mas a um sistema que se define a partir do momento em que os elementos desse conjunto interagem, ou seja, quando eles estabelecem relações. Portanto, um sistema pode ser definido 
como uma estrutura que se organiza com base em conjuntos de unidades inter-relacionáveis por dois eixos básicos: o eixo das que podem ser agrupadas e classificadas pelas características semelhantes que possuem e o eixo das que se distribuem com dependência hierárquica ou arranjo funcional. Assim, sistema é aqui entendido como um complexo de elementos em interação com seus atributos próprios e estes atributos também interagem entre si.

O sistema de espaços livres de uma cidade como São Paulo é o conjunto de todos os espaços livres de edificações existentes na malha urbana, sua distribuição, suas conexões e suas inter-relações funcionais e hierárquicas; englobando todos os espaços livres de edificação.

A formação de um sistema de espaços livres pode ser totalmente projetada, parcialmente projetada ou decorrente da somatória das intervenções locais, isto é, a existência de um sistema de espaços livres não presume a existência de um planejamento e um controle eficaz sobre este.

No município de São Paulo, além da considerável parcela de sua área urbanizada resultar de parcelamentos de solo irregulares e clandestinos, inexistiram planos efetivos para a consolidação de um sistema de áreas livres que se articulasse previamente a expansão do sistema viário nas áreas passíveis de urbanização e se definisse a hierarquização e distribuição das áreas de lazer nas suas diversas escalas de abrangência: cidade, região e bairro, orientando a reserva de áreas públicas nas glebas em processo de parcelamento formal.

As vias, configuradas durante o parcelamento de glebas, resultaram da aplicação de dimensões e percentuais mínimos exigidos por lei e, mesmo com a exigência de diretrizes prévias para o sistema viário principal, as normas vigentes não foram suficientes para induzir o traçado das vias limitando-se a definir parâmetros quantitativos, dimensões de calha e algumas outras regras gerais referentes à continuidade de vias existentes, 
iluminação e implantação de rede de infra-estrutura.

Assim, os espaços públicos, reservados para a implantação de praças e parques, seguiram parâmetros quantitativos e algumas especificações relativas ao relevo e dimensões mínimas. Não foram previstos critérios distributivos, embora a criação de áreas para a implantação de parques dependesse do porte da gleba a ser parcelada e também da reserva de uma área pública contínua.

Compõem então o sistema de espaços livres públicos de convívio, lazer e/ou conservação do município, abstratamente denominado de áreas verdes pelos órgãos municipais, as seguintes tipologias de espaços livres: praças, canteiros, áreas ajardinadas, áreas parcialmente ocupadas por equipamentos, parques estaduais, parques municipais e áreas de proteção ambiental (APA).

Hoje São Paulo conta com 31 parques municipais, 8 parques estaduais, 3 áreas de proteção ambiental estaduais, uma área de proteção ambiental municipal e, aproximadamente 2.800 praças. $^{21}$ Sendo que das tipologias citadas apenas as praças e parques configuram áreas de lazer e convívio ao ar livre. (Fig. 24, 25 e 26)

Fig. 24. Mapa do Estado de São Paulo indicando a distribuição das Áreas de Proteção Ambiental. Fonte: Secretaria do Verde e do Meio Ambiente - SVMA

${ }^{21}$ Base de dados da Secretaria Municipal do Meio Ambiente - Secretaria Municipal do Planejamento.

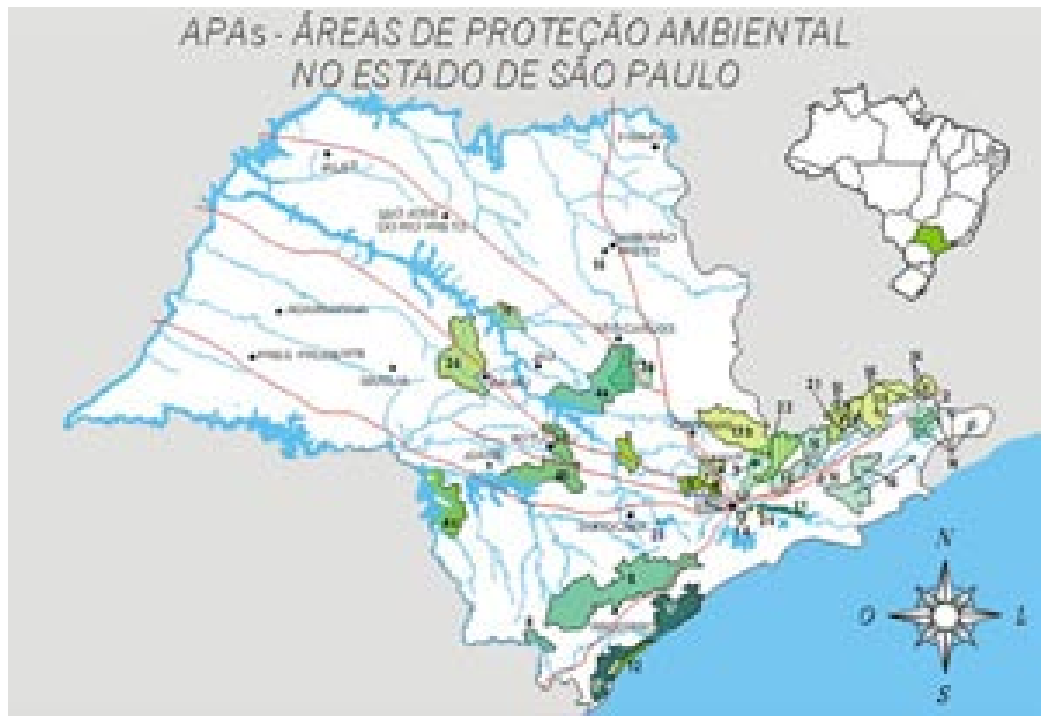


SISTEMA DE ESPACOS LIVRES PÚBLICOS DE LAZER EIOU CONSERVAÇĀO DO MUNICIPIO DE SĀO PAULO $\left(\mathrm{m}^{2}\right)$

\begin{tabular}{l|l|l}
\hline Tipologias de espaços em foco & $\mathbf{n}^{\bullet}$ & Área $\left(\mathbf{m}^{2}\right)$ \\
\hline Praças & 2785 & 6.875 .000 \\
\hline Canteiros & 759 & 4.111 .083 \\
\hline Areas 'ajardinadas" (estoque) & 710 & 2.116 .454 \\
\hline Areas com equipamentos comunitários & 530 & 1.957 .037 \\
\hline Parques Municipais de Så Paulo & 31 & 15.087 .683 \\
\hline Parques Estaduais do Municipio de Sao Paulo & 8 & 51.196 .896 \\
\hline Apas do Municipio de Sáo Paulo & 4 & 273.706 .000
\end{tabular}

As áreas de conservação ambiental correspondem a 18\% da área total do município, sendo significativas para o sistema, embora contenham áreas privadas em seu perímetro e estejam ameaçadas pela expansão da ocupação urbana. ${ }^{22}$ Para sua conservação, essas áreas dependem da existência e efetiva implementação de planos de manejo e gestão específicos.

Já o critério de destinação de áreas públicas em processo de parcelamento do solo, baseado apenas na área da gleba, desconsidera diferenças quanto à necessidade de áreas públicas nas diversas regiões da cidade, beneficiando assim as regiões mais ricas, onde os lotes são maiores, a densidade populacional é menor e a demanda de áreas públicas de lazer também é menor, em função da existência de áreas livres privadas de maior porte e da possibilidade de acesso às atividades de lazer privadas.

$\mathrm{Na}$ configuração do sistema, identificam-se áreas de porte diferenciado, mas não eqüitativamente distribuídas de forma a abrigar fins diversos e atender às demandas locais e regionais. (Fig. 27)

O mapa dos espaços livres públicos do município evidencia a concentração das áreas públicas existentes no setor sudoeste. Nos extremos da cidade, em especial nas zonas leste e sul, a escassez de áreas públicas de lazer atinge uma parcela

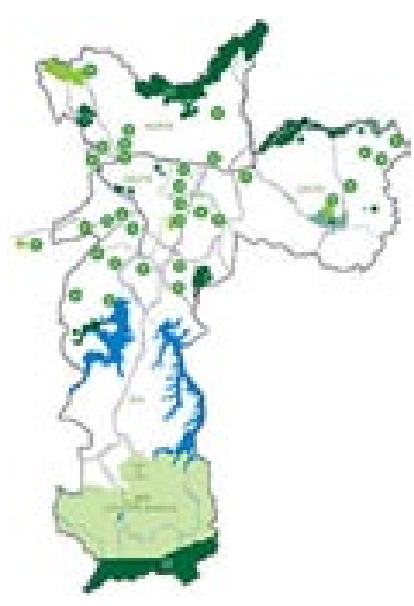

Fig. 25 e 26. Á direita Mapa indicando os principais parques e reservas da cidade de São Paulo.

Quadro quantitativo das praças e canteiros. Dados da Secretaria Municipal do Verde e do Meio Ambiente.

As áreas livres que compõem o sistema configuram um conjunto de fragmentos, com distribuição irregular, evidenciando a inexistência dos mesmos em determinados setores da mancha urbanizada, atingindo principalmente as áreas periféricas.

${ }^{22}$ São Paulo perdeu cerca de $30 \%$ de sua cobertura vegetal entre 1986-2000 
Fig. 27. Mapa das áreas públicas municipais.

O mapa mostra as áreas públicas do município indicando o porte. Fica evidenciado a presença do maior número de áreas na área central e no quadrante sudoeste, bem como a quase inexistência delas no nos extremos leste e sul do município. Fonte: Dados da Secretaria Municipal do Verde e do Meio Ambiente.

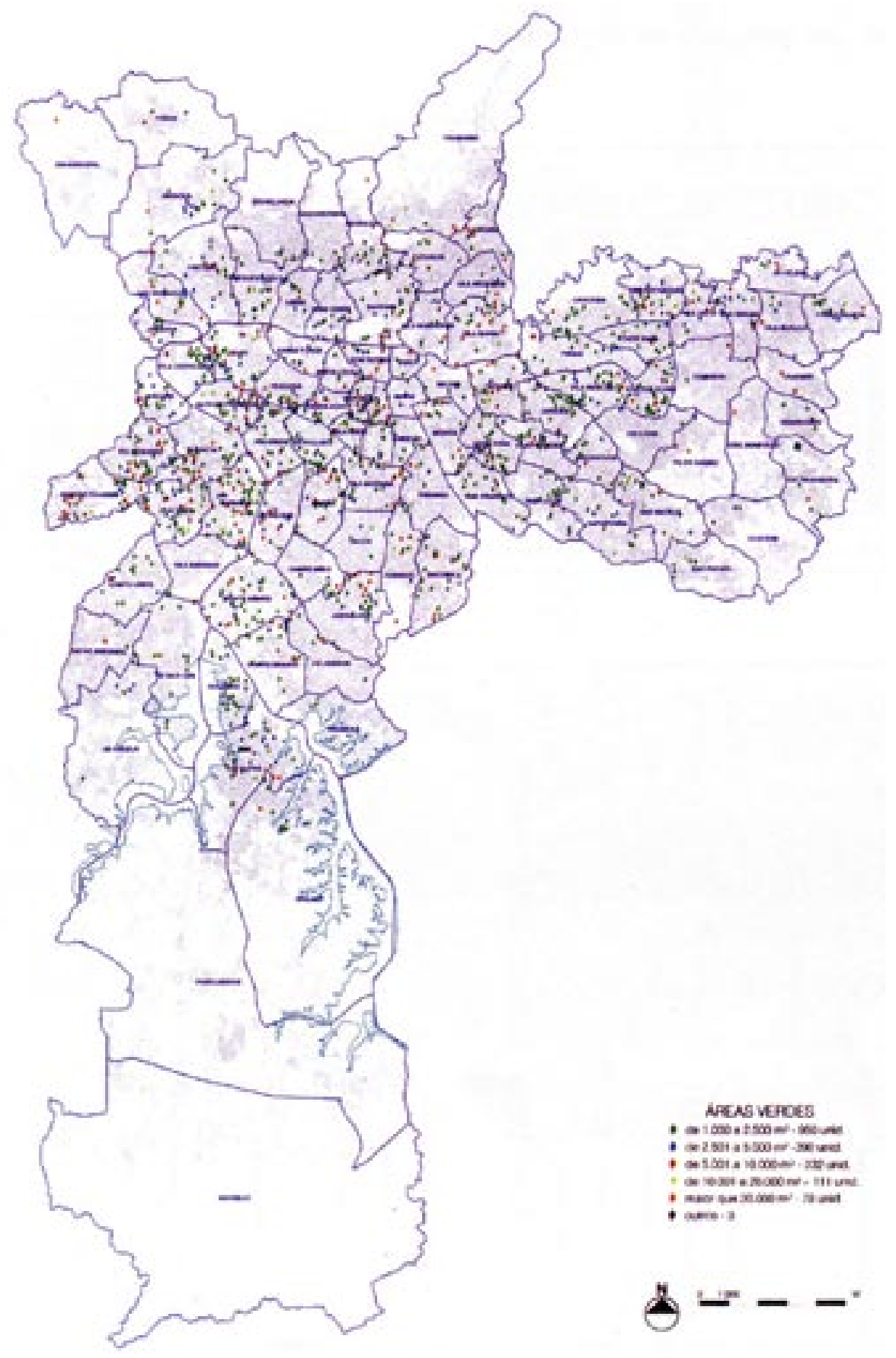


considerável do território, e são nessas áreas da periferia que a rua, além de ser um elemento de percurso e do sistema de parcelamento do solo, assume o papel de destaque como lugar de encontro e de representação da vida cotidiana, incorporandose a esse Sistema de Espaços Livres.

\section{o sistema viário}

Para a constituição do sistema de circulação, a legislação prevê, no momento do parcelamento das glebas e conseqüente abertura de novos bairros, a doação de $20 \%$ da área da gleba como áreas públicas destinadas às vias de circulação. Quando as vias projetadas não atingem os $20 \%$ pré-estabelecidos para o sistema viário, o restante de área pública é doado para integrar o conjunto de "áreas verdes públicas preservadas".

Hoje, o sistema viário estrutural do município é formado por um conjunto de vias distribuídas irregularmente pela área urbanizada da cidade, onde se verifica uma descontinuidade ao longo dos eixos de circulação; havendo uma maior concentração de vias de ligação no centro e no sudoeste da cidade. (Fig.28)

Essa descontinuidade das vias existentes contribui para a distribuição irregular das vias arteriais, uma vez que o prolongamento de muitas delas ocorreu a cada nova gleba parcelada.

A articulação viária foi realizada por meio de vários planos, com a abertura de novos eixos de circulação. Novas vias atravessaram bairros consolidados, exigindo desapropriações ou foram implantadas em fundos de vale, ocupando áreas de várzea sujeitas a inundações, sobre córregos totalmente canalizados ou nas margens de rios e córregos canalizados a céu aberto.

Assim, o processo de crescimento da cidade de São Paulo, muitas vezes aleatório, resultou na somatória de arruamentos e parcelamentos de solo, gerando uma malha viária onde se destacam em sua configuração a adoção, muitas vezes, de uma 
Fig. 28. Mapa do Sistema Viário Estrutural do Município Evidencia-se um conjunto e vias distribuídas irregularmente pelo município, privilegiando as ligações bairro e centro e faltando as ligações entre bairros.

Fonte: Secretaria Municipal do Planejamento - SEMPLA

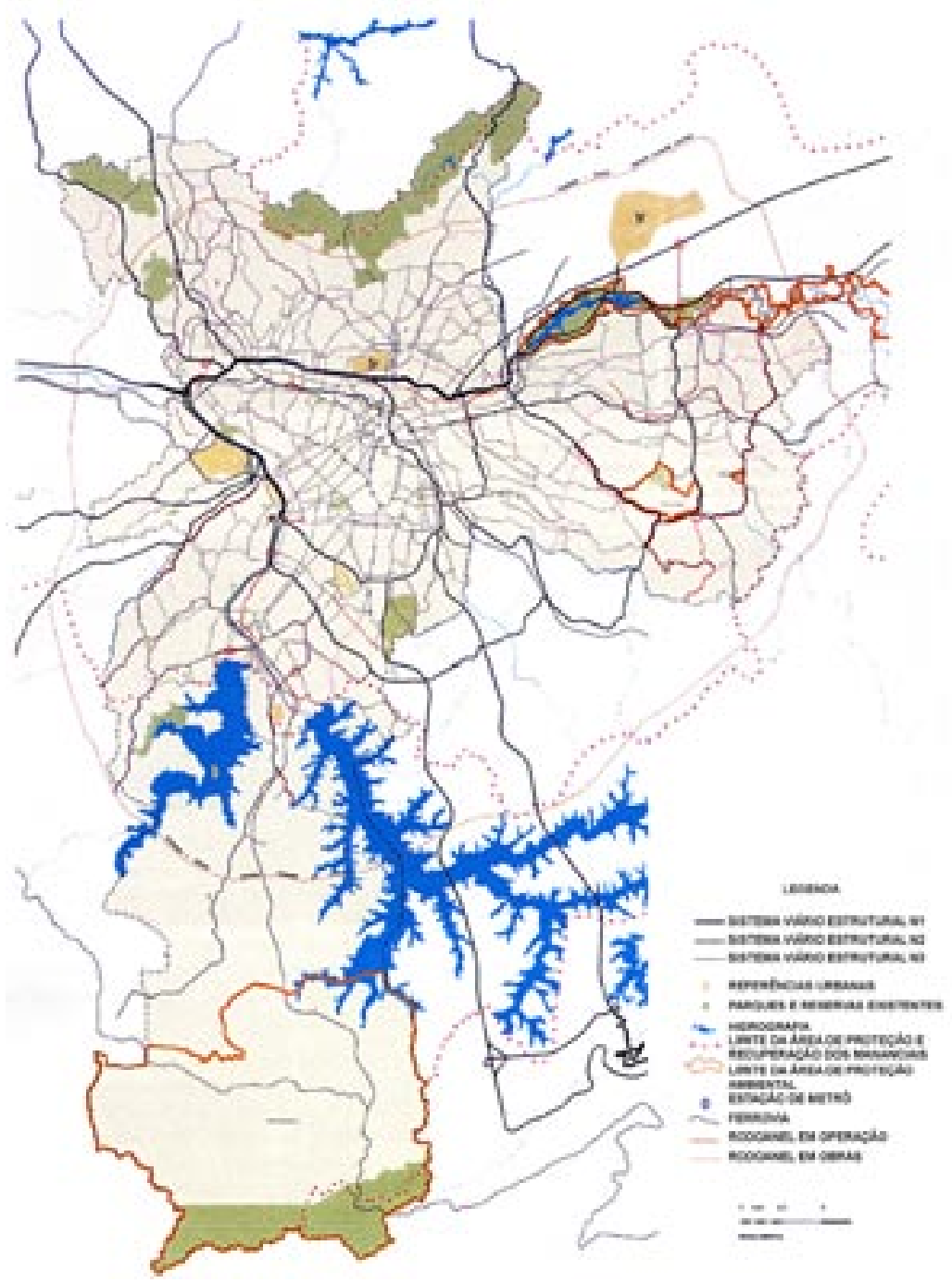

ortogonalidade que não garantiu a racionalidade e conexão entre o sistema viário proposto e o existente; projetos isolados de glebas que foram parceladas pela iniciativa privada, sem uma preocupação com a malha viária existente; e a desconsideração do relevo na implantação de loteamentos tipo "tabuleiro de xadrez".

O sistema viário é então composto por vias de circulação de veículos e pedestres, apresentando diferentes subdivisões. A 
lei prevê dimensões conforme a via proposta: largura mínima da vias, faixa carroçável mínima, passeio lateral mínimo e canteiro central mínimo. Porém, as características do sistema de circulação proposto pela legislação são generalistas e obsoletas, pois não atendem às necessidades da sociedade contemporânea face o aumento da densidade populacional e a conseqüente redução do tamanho dos lotes; respeitando as limitações dos deficientes físicos e visuais, além de outros.

Além de serem enquadradas em hierarquias com diferentes categorias para as vias de circulação de veículos, vias arteriais e via de circulação de pedestres; segundo Menneh, as ruas apresentam tipologias que recebem diferentes denominações ligadas a aspectos formais e tradições culturais, podendo variar conforme porte, desenho ou tipo de tratamento paisagístico, e correspondem as seguintes denominações:

Calçadão ou rua de pedestres: via exclusiva para o fluxo de pedestres, onde o tráfego de veículos é restrito;

Beco, viela, ruela: sempre sugerem uma passagem estreita e muitas vezes curta;

Bulevar: geralmente configura uma avenida com passeios largos, canteiros ajardinados, com uma ou mais linhas de árvores;

Via parque: via que ladeia faixas de áreas livres, formando um parque linear (deriva de propostas desenvolvidas por Olmstead);

Alameda: rua arborizada;

Avenida: uma via larga, geralmente com mais de uma pista de várias faixas de rolagem;

Via expressa: via de trânsito rápido, em face da inexistência de cruzamentos em nível;

Estrada: quase sempre se refere à via de trânsito rápido que liga dois ou mais municípios ou bairros distantes com descontinuidade de áreas urbanizadas; 
Vias locais: via geralmente mais estreita que a avenida, com baixo tráfego de automóveis.

\section{o sistema de parques}

Em relação às áreas verdes de lazer do município nunca faltaram propostas de parques e áreas verdes nos planos propostos fossem de higiene urbana, recreação pública ou de ordem estética: o de Bouvard de 1911, que desenhava um percurso de passeios interiores interligando os parques, o de Parker que indicava as vantagens de um cinturão verde em torno da cidade, o de Saturnino de Brito e o plano de avenidas de Prestes Maia,

Do ponto de vista de programas e de projetos de parques, nunca se investiu suficiente neles. Era nas várzeas dos rios, sem quaisquer benfeitorias, que boa parte da população, principalmente masculina, se recreava nos famosos campinhos.

Desde o início do século passado é possível, como vimos anteriormente, a doação de parcelas significativas de áreas públicas, provenientes de loteamentos de maior porte para a implantação de áreas verdes de lazer e convívio, mas sua necessária continuidade para a implantação de parques, depende da atuação do poder público no momento da efetivação das diretrizes para o parcelamento do solo, quando são escolhidas as áreas a serem doadas à municipalidade.

A esse respeito, Vladimir Bartalini (1999) observa que $43 \%$ dos parques municipais existentes, foram implantados em áreas livres de loteamentos. É um numero significativo porém, corresponde a menos de 72 hectares. A maior parcela das áreas onde foram implantados os parques resultou de desapropriações e o restante foi implantado em terras públicas.

Em relação à distribuição dos parques existentes, verificamos que a situação de escassez se mantém, mesmo com o agrupamento dos distritos municipais nas diversas 
Sub-prefeituras, muitas delas sem parques em seu perímetro. Entretanto, a importância dos parques no sistema de lazer do município é confirmada quando agregamos os dados referentes aos parques em setores maiores, uma vez que todas as regiões do município contam com parques públicos. (Fig. 29 e 30 e Tab. 1 e 2)

Comparando os gráficos de números e metragem quadrada de parques nas diversas regiões, verificamos o porte das áreas existentes. A região oeste conta com um número significativo de parques, mas os mesmos apresentam menores dimensões. As regiões leste 2 e norte 2, contam com grandes parques em seus extremos: o Parque Anhanguera e o Parque da Capitalantigo Parque ecológico do Tietê. (Tab. 2a)

São Paulo conta com duas grandes áreas de lazer utilizadas intensamente pela população: o Parque do Ibirapuera, localizado na Zona Sul da cidade, com 130 mil usuários aos domingos; e o Parque do Carmo, na Zona Leste, com 84 mil usuários.

Com uma freqüência menor, destacam-se ainda o Parque Ecológico do Tietê, no extremo da zona leste do município; o Parque Vila Lobos e o Parque Fernando Costa na zona oeste, e

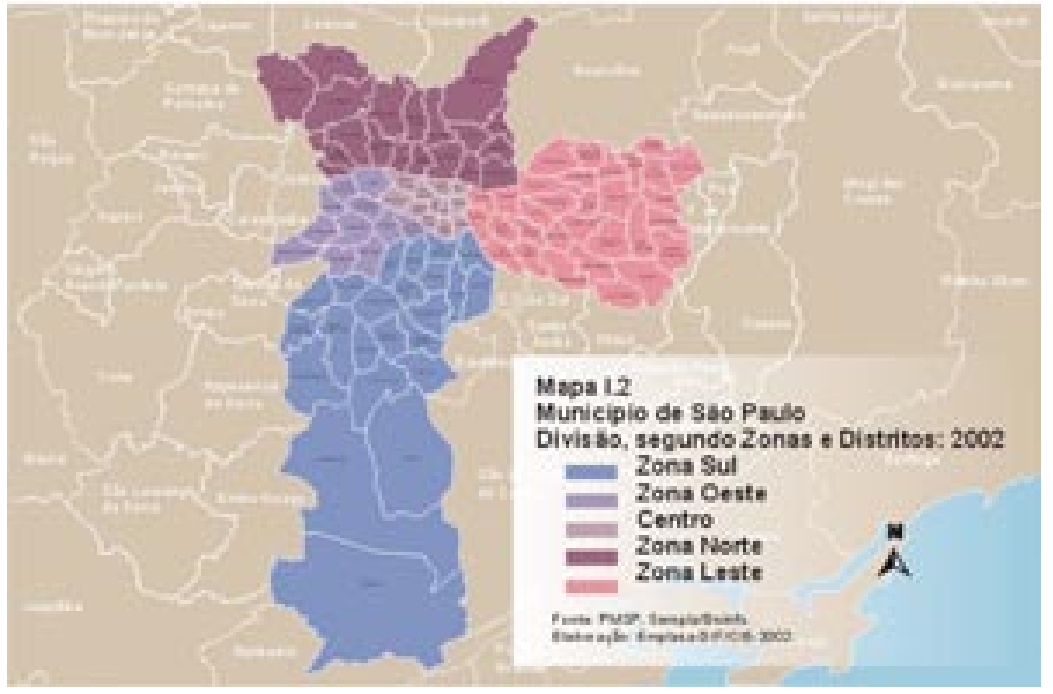

Fig. 29. Mapa indicativo das Sub-regiões do município de São Paulo.

Fonte: PMSP - Prefeitura do Município de São Paulo. 
Fig. 30. Mapa de São Paulo indicando a divisão das Subprefeituras. Lei Municipal 13.399/02 Fonte: Secretaria Municipal de Planejamento - SEMPLA

Tab. 1. Quadro quantitativo de distribuição de parques no município

Fonte: Dados da Secretaria Municipal do Planejamento - SEMPLA

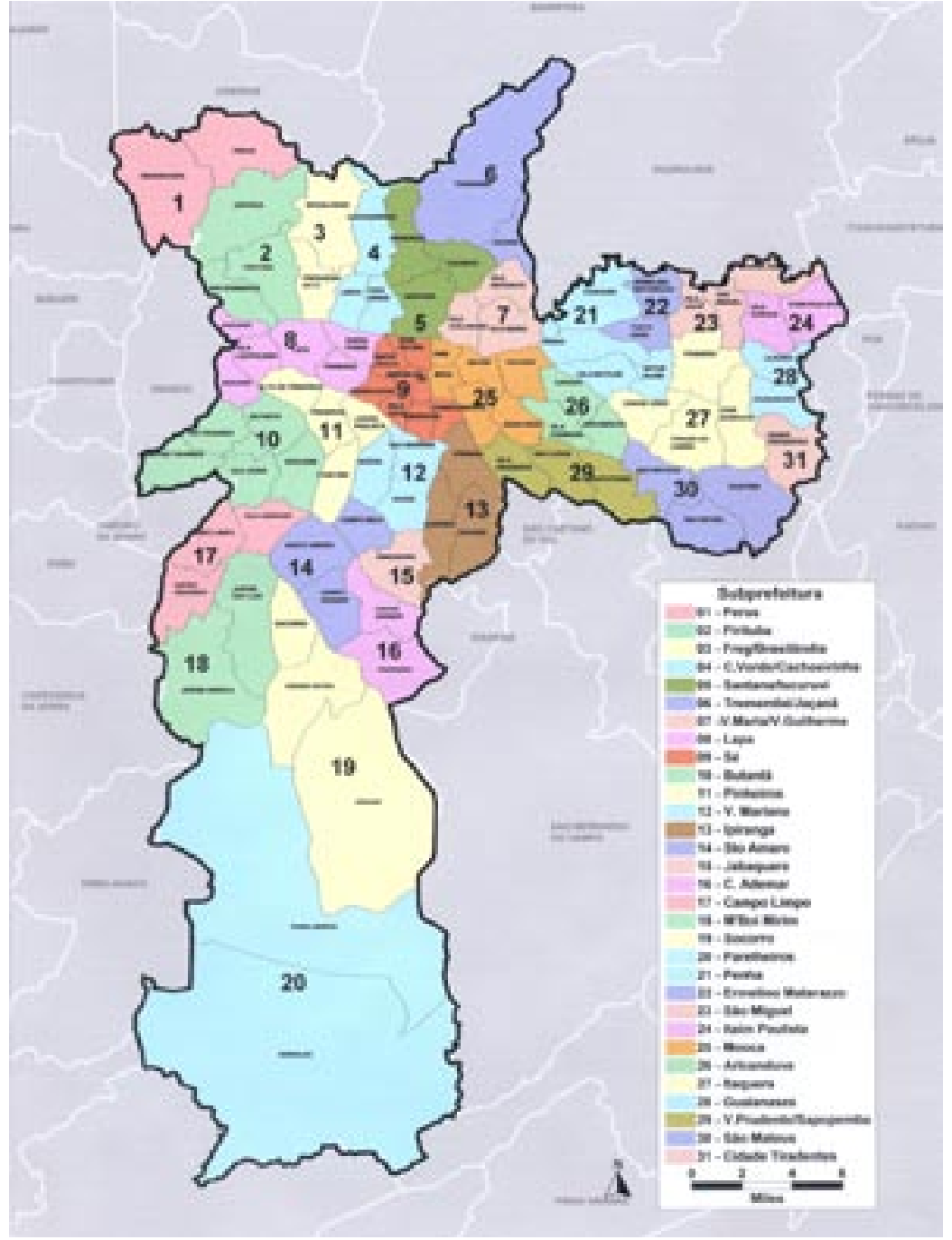

\section{Número de parques, por regiăo}

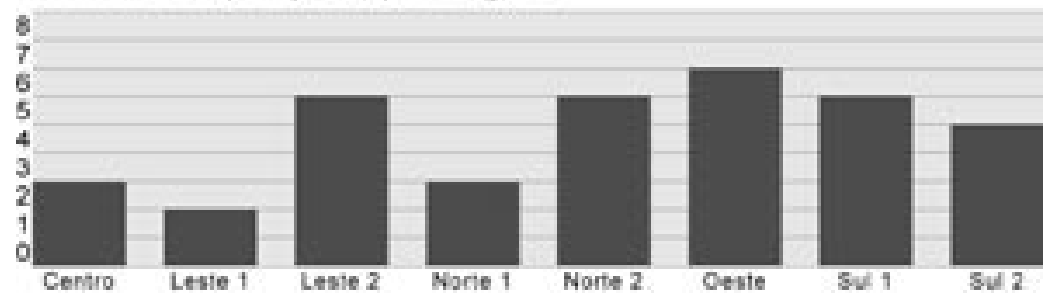




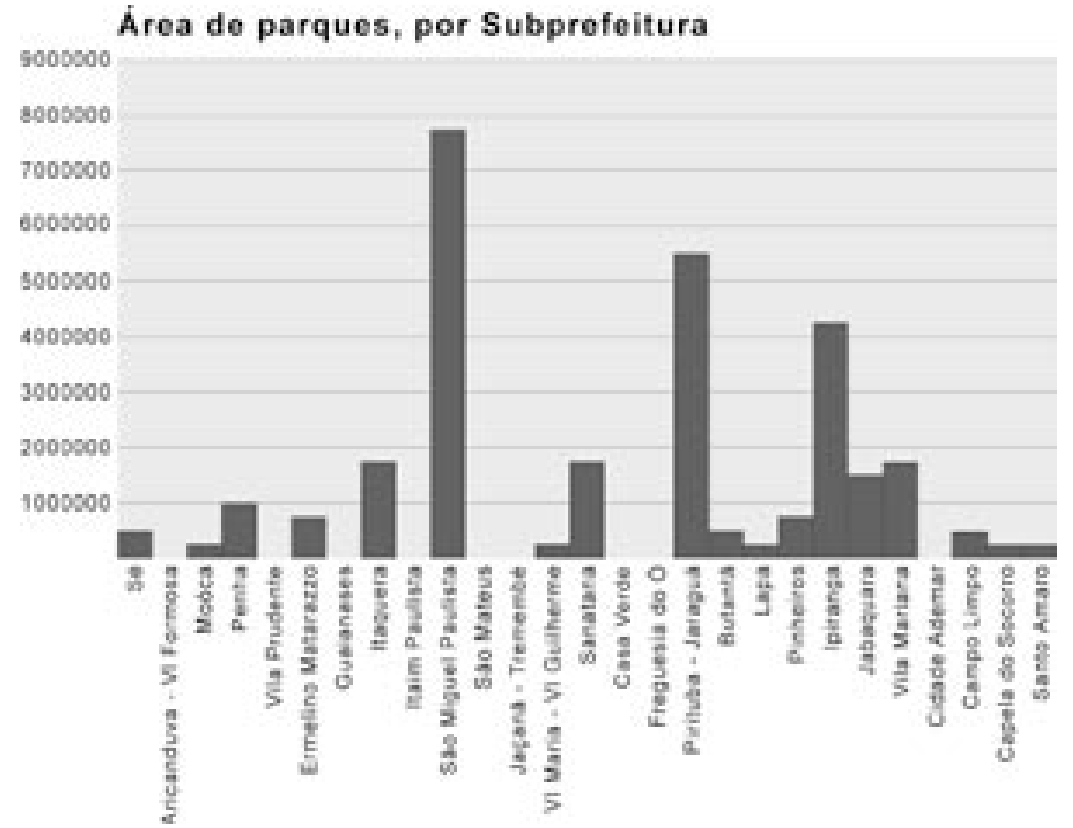

Sistema de parques no Município de Săo Paulo

\begin{tabular}{|c|c|}
\hline Parques Nunicipais & Área $\left(m^{2}\right)$ \\
\hline Pg da Aclimaço & 18.797 \\
\hline $\mathrm{PQ}$. Nrredo Volpi & 142400 \\
\hline $\begin{array}{l}\mathrm{Pq} \text {. Athangueta } \\
\text { (area vilizavel } 8.000 .000 \mathrm{~m}^{3} \text { ) }\end{array}$ & $\$ 997350$ \\
\hline Pq Bzense Aires & 22200 \\
\hline [praça final ate XIX] & 22.200 \\
\hline Pg. Ben Marx & 456894 \\
\hline Pa do Carmo & 1.548630 \\
\hline $\mathrm{Pq}$, Cemutam (situado en Cota) & 500000 \\
\hline Pa. Chice Mendes & 61.600 \\
\hline (amt. Fiqueira Grande) & 01000 \\
\hline $\mathrm{Pa}$. Cisade de Torento & 109.100 \\
\hline Pa. Eucaliptas & 10098 \\
\hline $\mathrm{Pq}$. Guarasiranga & 152608 \\
\hline Pq, Ibirapuera & 1.505 .000 \\
\hline Pa. independéncia & 184.830 \\
\hline Pq. Ad. Felicisade & 26.00 \\
\hline PQ. Lisa e Pavio Raia & 15.000 \\
\hline (ant, Cencaiça) & 15000 \\
\hline $\mathrm{Pq}$. Lians Club Fucurux & 23.604 \\
\hline $\mathrm{Pq}$ Lus Cartos Prestes & 27.190 \\
\hline (amt. Relinspois) & 27.108 \\
\hline $\mathrm{Pa}$ da lut & 113.400 \\
\hline $\mathrm{Pq}$. do Nabuso & 31300 \\
\hline $\mathrm{Pq}$ do Pioven & 97.200 \\
\hline Pa. Previstencia & 91.500 \\
\hline $\mathrm{Pq}$. Ragoso Tavares & 195.000 \\
\hline
\end{tabular}

\begin{tabular}{|c|c|}
\hline Parques Municipals (teot.) & Ares $\left(m^{2}\right.$ \\
\hline PQ Rad Seisas & 39000 \\
\hline PQ. Rodrigo Gaspeti & 39.600 \\
\hline Pq Santa Amelia & 34000 \\
\hline PQ. Santo Dias (ace Asvertiats) & 134.000 \\
\hline $\mathrm{Pa}$ sao Demingos & 00000 \\
\hline Pa. Severo Comes & 34.500 \\
\hline (ant. Granja Julieta) & 34.000 \\
\hline$P Q$ ten siqueira campos & 46.000 \\
\hline (ant. Trianon) & 48600 \\
\hline Pq, Wha Galherne & 62600 \\
\hline (Soe. Paulsta de Trote) & 62000 \\
\hline Pa. Vie dos Mamdalige & 100.000 \\
\hline Tetal & 15.987 .693 \\
\hline Parques Estaduais & Area $(i n$ ') \\
\hline Pa Est. Mberto & 1740.000 \\
\hline (Worto Florental] & 1.740 .000 \\
\hline Pa. Fernando Cesta (Agua Branci & a) 115.208 \\
\hline Pe. fet. Fontes do lpiranga & 5426.156 \\
\hline fant. Pa. do Estado & 5.428 .156 \\
\hline Pa do Jarapua & 4 ละด 400 \\
\hline Pa. Er Vila tobes & 717.000 \\
\hline PQ. Eat da Capizal & 0.297 .106 \\
\hline cant. Pa. Esol. 0 & 9297.100 \\
\hline PQ Eat da Cantareira (parte) & 20.011 .034 \\
\hline Tetal & $51.196 \geq 96$ \\
\hline
\end{tabular}

Tab. 2. Quadro quantitativo de distribuição de parques - $\mathrm{m}^{2} /$ Subprefeitura.

Fonte: Dados da Secretaria Municipal do Planejamento - SEMPLA
Tab 2a - Relação de Parques Estaduais e Municipais 
Fig. 31 (ao lado). Foto aérea do Parque do Ibirapuera na Zona Sul do Município. Fonte: Google Earth, 2002

o Horto Florestal na zona norte; indicando a importância desses parques nas respectivas regiões. (Fig. 31 a 34)

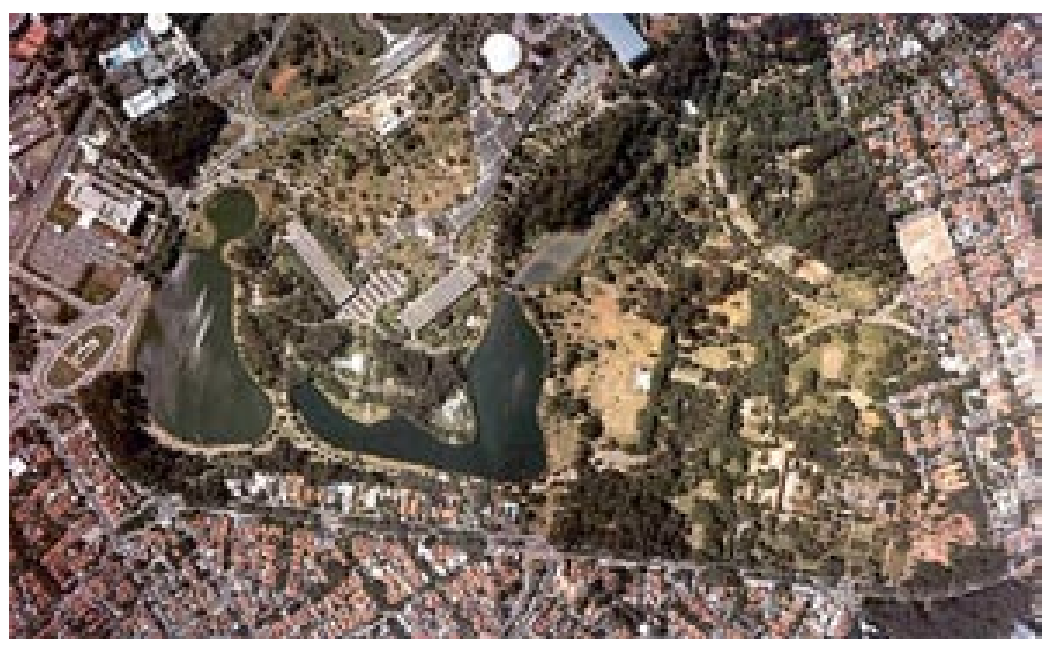

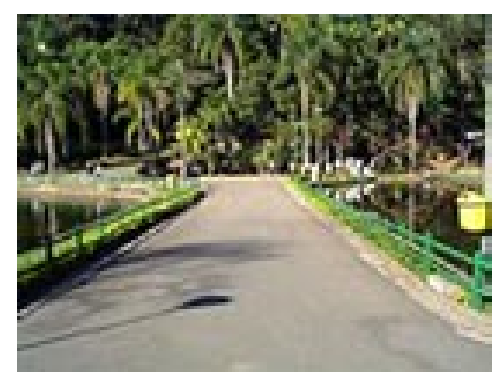

Fig. 32, 33 e 34 (acima). Parques do Horto Florestal, Villa Lobos e do Carno, respectivamente. Fonte: Arquivo pessoal
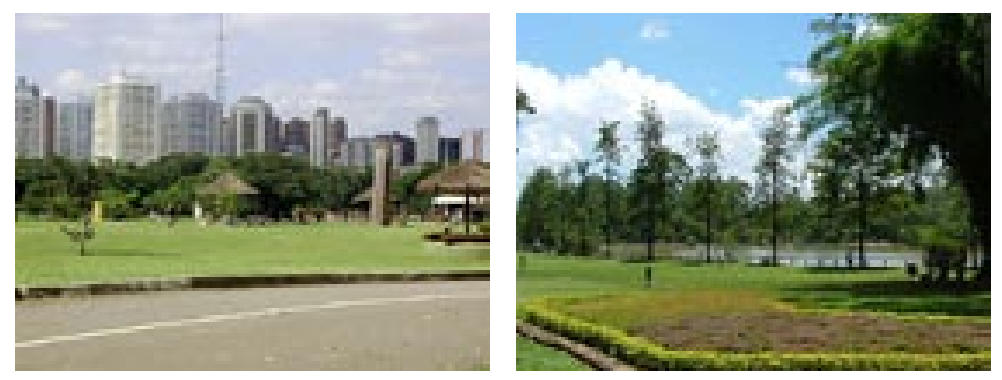

Ainda sobre a questão da frequência de usuários aos parques municipais, Bartalini comenta que apesar de poucos, eles ainda possuem um papel importante nas opções de lazer da cidade. Muitos dos frequentadores visitam os parques mais de uma vez ao mês e permanecem nele de duas a quatros horas. Outro fato destacado por Bartaline, é o grau de abrangência dos parques, que atraem frequentadores de um raio de $10 \mathrm{~km}$, sendo a maioria proveniente de distritos de baixo índice de qualidade de vida.

Sendo assim, os parques, ainda que insuficientes, são significativos para o sistema de lazer e convívio do município, em especial se considerarmos a pequena metragem de praças 
existentes; e recebem aproximadamente 320 mil usuários aos domingos. ${ }^{23}$

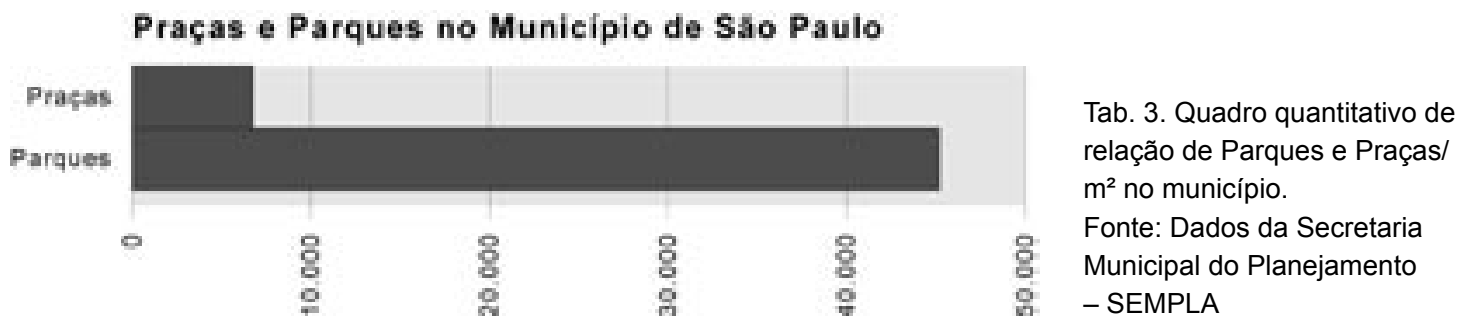

\section{o sistema de praças}

A existência de loteamentos clandestinos em São Paulo, principalmente concentrados na periferia das zonas sul, leste e norte da cidade, agravou a situação de distribuição irregular das áreas livres públicas, especialmente das praças.

A cidade de São Paulo conta hoje com aproximadamente 2.800 praças, que correspondem a $0,46 \%$ da área total do município, distribuídas de forma irregular e compostas principalmente de pequenas dimensões $-76 \%$ possui menos de $5.000 \mathrm{~m}^{2}$, e destas, $54 \%$ menos que $2.500 \mathrm{~m}^{2}$ (tratadas ou não).

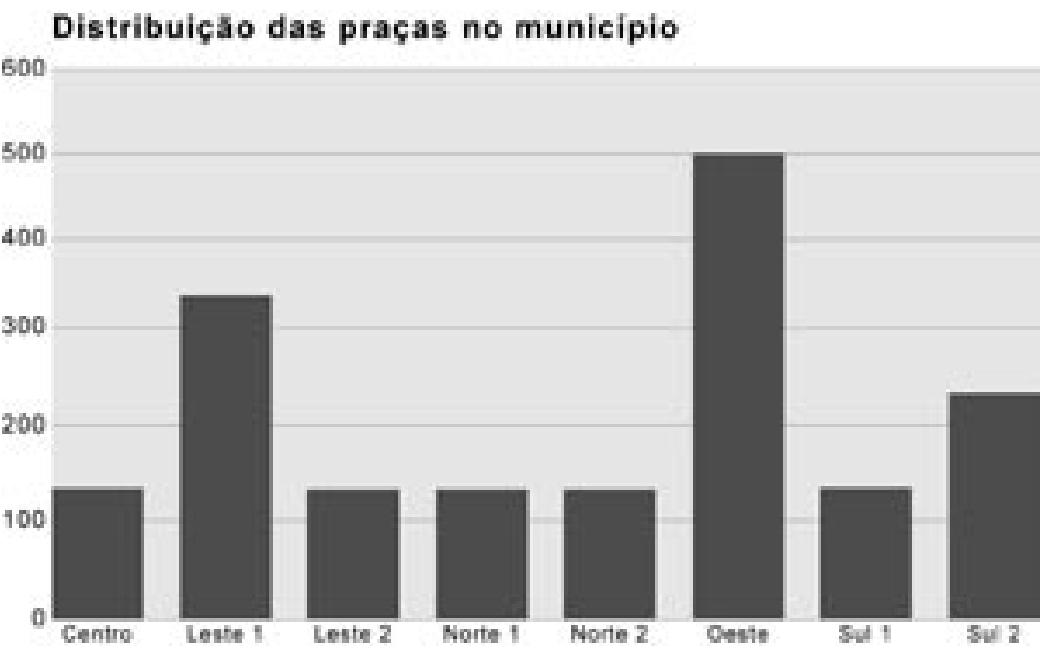

Tab. 4. Quadro quantitativo de distribuição de praças no município

Fonte: Dados da Secretaria Municipal do Planejamento - SEMPLA

${ }^{23}$ Dados da Secretaria Municipal do Meio Ambiente 
Tab. 5. Quadro quantitativo de distribuição de parques - $\mathrm{m}^{2} /$ Subprefeitura. Fonte: Dados da Secretaria Municipal do Planejamento - SEMPLA

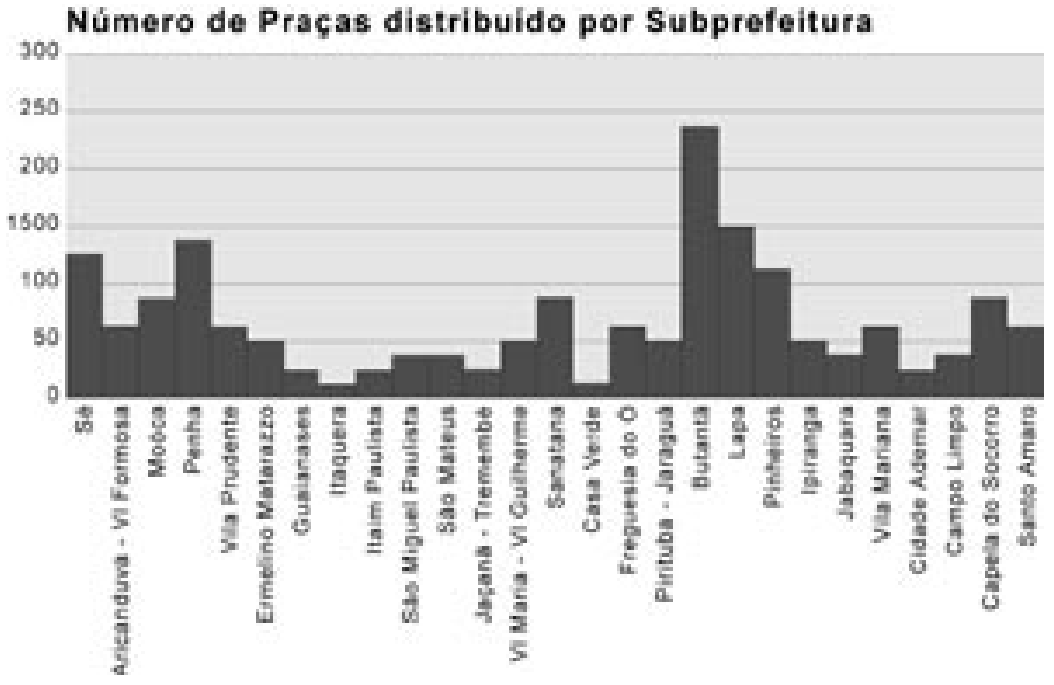

Segundo Menneh, estas "praças" podem ser classificadas por tipologias, conforme uma de suas funções no sistema:

- Praças com equipamentos comunitários, ocupadas total ou parcialmente;

- $\quad$ Praças com equipamentos de lazer;

- Praças ajardinadas;

- Praças formadas por restos de quadras urbanas,

- Praças do sistema viário: subdivididas em alças de acesso a avenidas, alargamentos de canteiros centrais e rotatórias.

Mas, independentemente das características tipológicas ou estéticas que apresentam, são as praças que permitem, na escala dos bairros o lugar propício à razão comunicativa colocada por Milton Santos, quer na dimensão cotidiana da esfera da vida ativa, quer na escala política, principalmente na periferia. São nestes espaços que as espacialidades do cotidiano revelam sua capacidade de assimilação e transformação das racionalidades hegemônicas pela população, podendo-se verificar diferentes formas de apropriação de seus espaços, estabelecendo novos vínculos sociais, e por isso, merecem um lugar de destaque e são o foco deste estudo. 


\section{os cdm's}

Na tentativa de suprir as necessidades de lazer ao ar livre, houve na década de 1950, grande expansão das associações recreativas, conhecidas como clubes esportivos, organizadas pela sociedade civil. Paralelamente, a Prefeitura de São Paulo, através da Secretaria Municipal de Esportes, criou os Clubes Desportivos Municipais - CDMs, para o atendimento da população que não tem acesso aos clubes privados.

Esses clubes são equipados pelo poder público com quadras, campos de futebol, vestiários, sedes e lanchonetes; e teoricamente administrados pela comunidade. O que acontece na realidade, em alguns casos, é que um grupo específico geralmente liderado por um vereador ou algum membro de peso político, acaba "tomando conta" da área e, infelizmente o acesso fica restrito a interesses desse grupo e a comunidade mais uma vez fica prejudicada.

Sua importância no sistema de espaços livres de lazer no município deve-se, principalmente, à sua distribuição em todas as regiões da cidade e, de certa forma, compensam "em parte", o déficit de áreas públicas de lazer e convívio ao ar livre. 


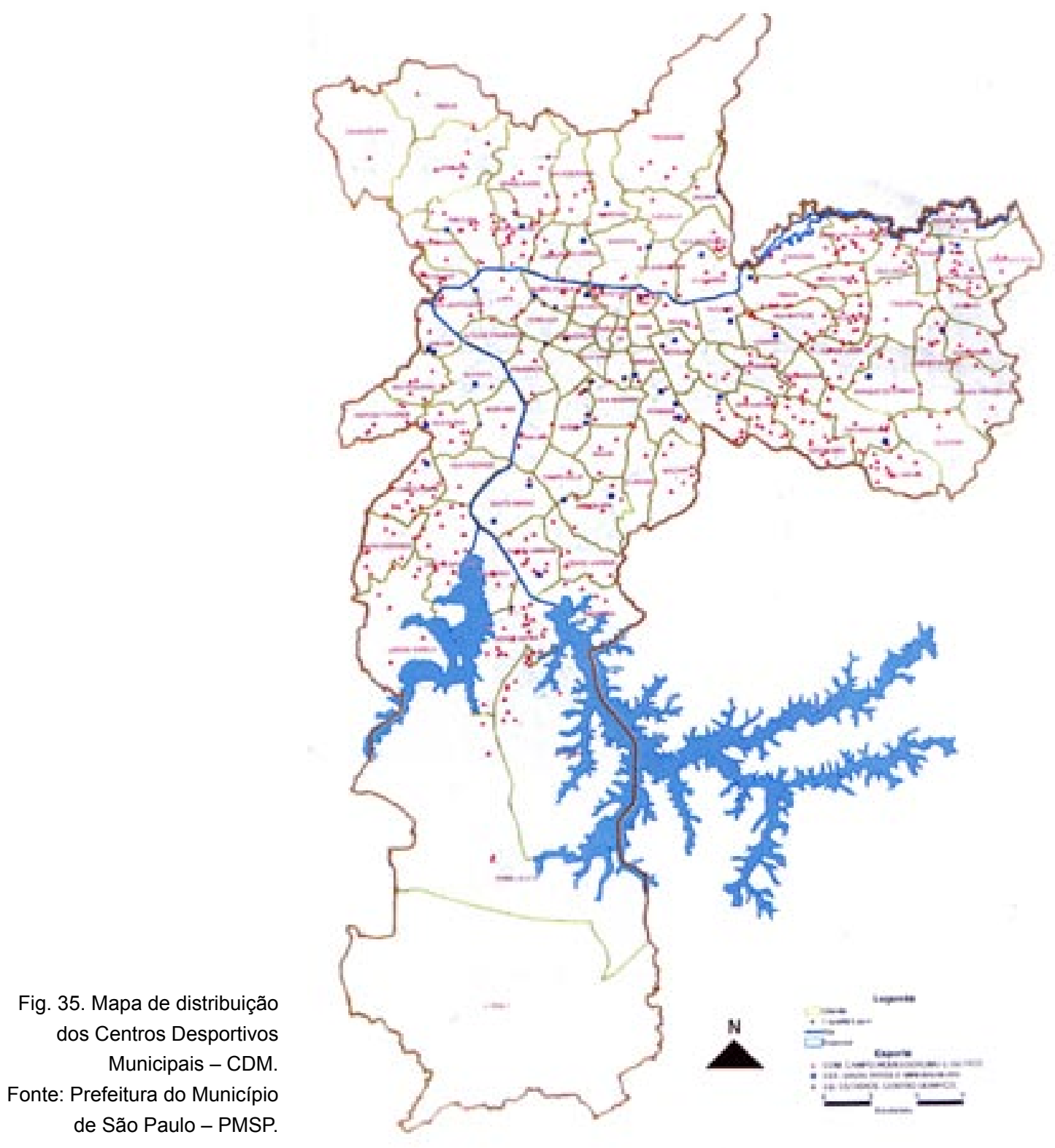




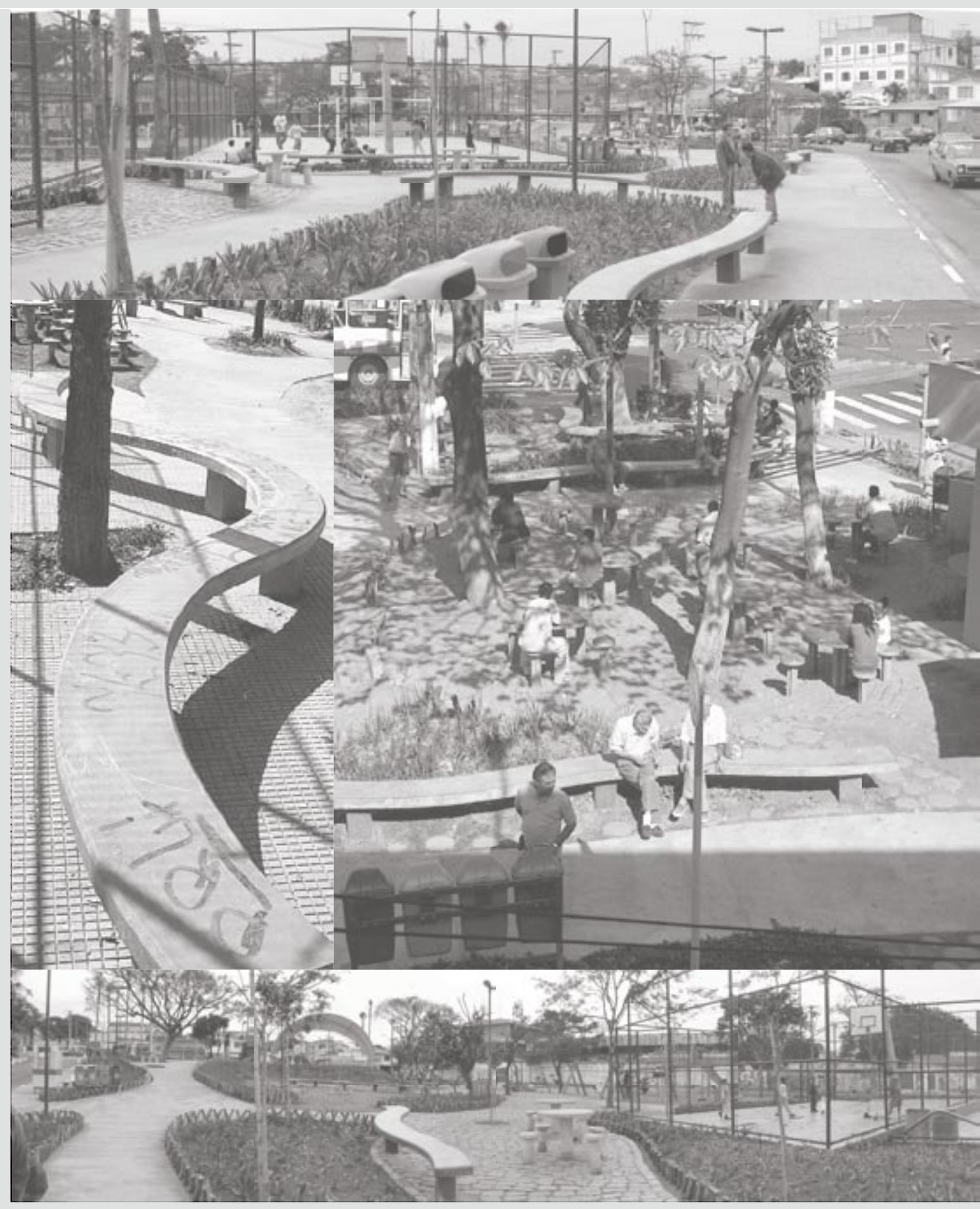




\section{C a pít u l o 04 \\ O PROGRAMA CENTROS DE BAIRRO}

Acidade de São Paulo, quer pela sua dimensão, quer pela sua ocupação, muitas vezes predatória, apresenta, como pudemos verificar nos capítulos anteriores, contrastes amplamente conhecidos de oferta de equipamentos públicos e de áreas qualificadas para o uso coletivo, sobretudo na sua periferia.

O processo de metropolização intenso entre as décadas de 1950 a 1980, gerou demandas sociais às quais a municipalidade muitas vezes, não conseguiu equilibrar e organizar o espaço como um todo.

Formaram-se então pela periferia da cidade, vários subcentros, caracterizados por ruas de comércio popular muito semelhantes entre si - poluição visual ocasionada pela presença de letreiros, faixas, tipos de lojas, trânsito lento de ônibus e automóveis.

Os espaços livres estão distribuídos desigualmente e se contrastam com áreas de elevadas taxas de impermeabilização e outras de maiores extensões de preservação da vegetação nativa (como são as áreas vegetadas dos limites urbanos, principalmente da zona norte e da zona sul da cidade).

A degradação dos espaços públicos, juntamente com o receio e a insegurança da população quanto a eles, fizeram com que houvesse um abandono cada vez maior destas áreas, o que por sua vez aprofundou ainda mais essa degradação, ocasionando a sensação de descuido e de violência possível e iminente.

A partir destas constatações e do conhecimento de áreas de exclusão social na cidade de São Paulo, com pouco ou nulo investimento público, a Prefeitura do Município de São Paulo criou em 2001, sobre a gestão da então prefeita Marta Suplicy, o Programa Centros de Bairro, que está apresentado aqui como elemento constituinte do Sistema de Espaços Livres da Cidade de São Paulo. 
4. O Programa Centros de Bairro 
Apoiado em experiências já implantadas de cidades próximas (como os casos de requalificações de áreas públicas nas cidades de Sto. André e Santos), procurou-se em parceria com algumas secretarias (transportes, educação,...) e outros órgãos municipais (sub-prefeituras, CET, SPTRANS,...), estudar e entender esta realidade e, na proporção possível, minimizar alguns dos efeitos resultantes do processo de urbanização.

Delimitou-se então, para o ano corrente de 2002/2003, projetar e implantar "lugares de cidadania", distribuídos na periferia da cidade de São Paulo. Equipamentos de esporte, lazer e cultura faziam parte do programa estipulado para essas áreas; ou apenas formar áreas de referência ambiental e paisagística, priorizando fundamentalmente a comunidade moradora e freqüentadora destas áreas, perfazendo um total de $1.000 .000 \mathrm{~m}^{2}$ - menos de $0,1 \%$ da área total do município, mas superior à área do principal parque da cidade, o Parque do Ibirapuera.

Tab. 6. Quadro de evolução do Programa Centros de Bairro. Fonte: Sakata, 2005

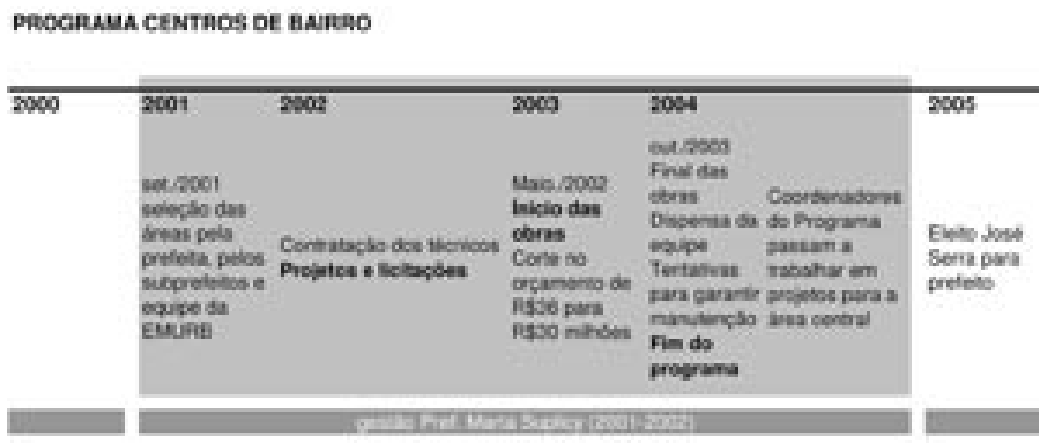

Um dos objetivos era retomar a importância do projeto paisagístico e da questão ambiental como componentes da construção do meio urbano.

Nesta proposta, o projeto paisagístico não foi visto apenas como uma possibilidade (fruto do desinteresse, ignorância ou precariedade de verbas), mas como uma necessidade vital para 
o futuro da cidade, capaz de criar lugares de cidadania, com espaços públicos democratizados e qualificados, possibilitando o convívio social entre os freqüentadores de distintas faixas etárias.

Elaborado na sua concepção como uma intervenção que fosse capaz de funcionar, no futuro, como um sistema de espaços públicos, o Programa Centros de Bairro projetou e implantou 49 praças, ou ambiências urbanas de vizinhança, tendo como público alvo os moradores e freqüentadores da vida pública ativa das respectivas áreas e contemplando distintos pontos da periferia da cidade.

Com um desenho despretensioso e menos elaborado quando comparado à sofisticação estética de alguns espaços livres da arquitetura paisagística contemporânea, mas nem por isso sem qualidade, o programa procurou trabalhar com materiais econômicos e alternativos (re-utilização de guias e paralelepípedos que haviam sido retirados de outras áreas, pneus...). A linguagem, de fácil apreensão pela população, poderia ser repetida, de uma forma menos consciente e mais popular, para uma possível propagação dessas "ambiências urbanas" pelos bairros mais pobres da periferia de São Paulo.

O programa foi gerenciado pelo gabinete da prefeita e efetivado pela EMURB (projetos, licitação e obras), sendo o responsável pelos trabalhos o $\mathrm{Arqt}^{\circ}$ Sérgio Marin de Oliveira, que montou uma equipe que também contou na coordenação com o $\mathrm{Eng}^{\circ} \mathrm{Agn}^{\circ}$ José Carlos Perdigão e com a presença de mais 10 profissionais entre arquitetos e agrônomos. A verba alocada foi de $R \$ 36$ milhões que foram distribuídos nas 49 áreas de intervenção.

Enquanto era montada a equipe para o trabalho (composta por 5 arquitetos e 5 agrônomos), foi elaborado um caderno com as intenções do programa e encaminhando às subprefeituras. As subprefeituras deveriam recomendar áreas para receberem as intervenções, preferencialmente com confluência de um grande 
número de pessoas e que fossem pontos de grande visibilidade, não necessariamente centralidades dos bairros.

De modo geral o impacto foi mais marcante nas áreas mais carentes, onde o trabalho não foi de requalificação e sim de qualificação dos espaços públicos e, onde, praticamente, havia a inexistência desses espaços.

Embora distribuídas pelas diferentes zonas da cidade, as intervenções não atingiram toda a população. Como se tratavam de praças, e não de obras viárias por exemplo, sua abrangência foi menor. As áreas em questão, enquanto equipamentos urbanos, atenderam à população do entorno próximo a elas; e a maior parte da população não ficou sequer sabendo da existência do programa.

Mas o fato do programa não ter beneficiado toda a população não tira seu mérito pois, tratando-se de uma cidade como São Paulo, uma pequena porcentagem significa milhares de pessoas e, na maioria dos casos, em áreas extremamente carentes. Além disso, seus pontos positivos serviram como base de referências e modelos para intervenções futuras realizadas pelas próprias subprefeituras ou outros órgãos municipais como a SPTRANS (São Paulo Transportes) e a CET (Companhia e Engenharia de Tráfego) que antes não incluíam o projeto paisagístico como escopo de suas intervenções.

\section{A d i st ribu içã o pe I a c i d a d e}

As intervenções foram realizadas em espaços públicos, particularmente praças, na proximidade de escolas, postos médicos, comércio popular, mercados, entorno de terminais de ônibus, enfim, espaços geralmente degradados e com problemas ambientais.

Em conjunto, a EMURB (Empresa Municipal e 
Urbanização), a prefeita junto com os subprefeitos estabeleceram um total de 57 áreas de intervenção, uma média de 2 a 3 áreas por subprefeitura, distribuindo-se tanto por subprefeituras mais carentes como Capela do Socorro e Guaianazes, como em outras mais tradicionais e consolidadas como foi o caso da Penha. Entretanto, algumas áreas não tinham de fato as características preconizadas inicialmente ou o potencial para se tornarem áreas de lazer. Apesar de ter havido critérios técnicos para a escolha das áreas, nem todas se mostraram adequadas para

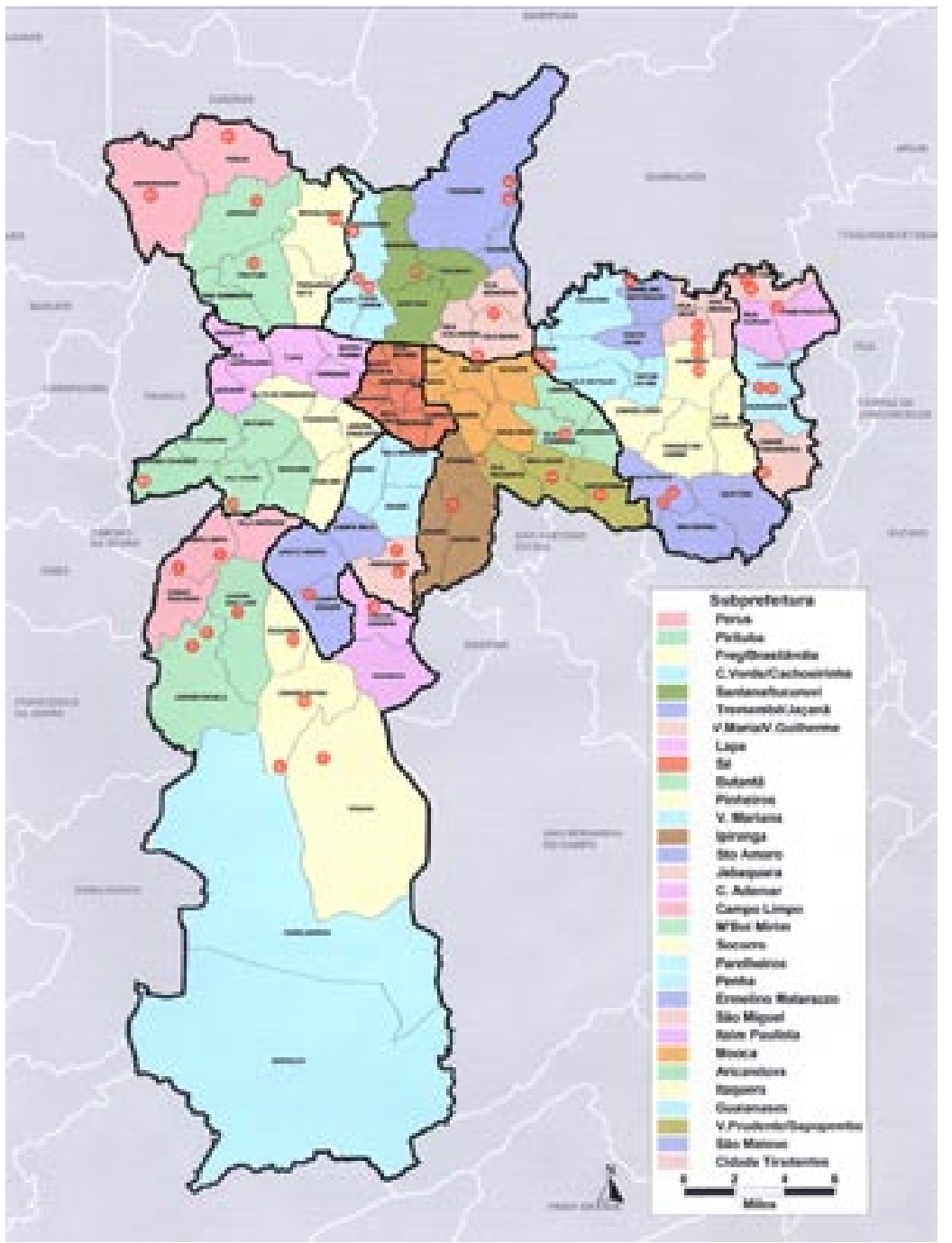

Fig. 36. Mapa indicativo da distribuição das praças do Programa Centros de Bairro pelas diferentes zonas da cidade.

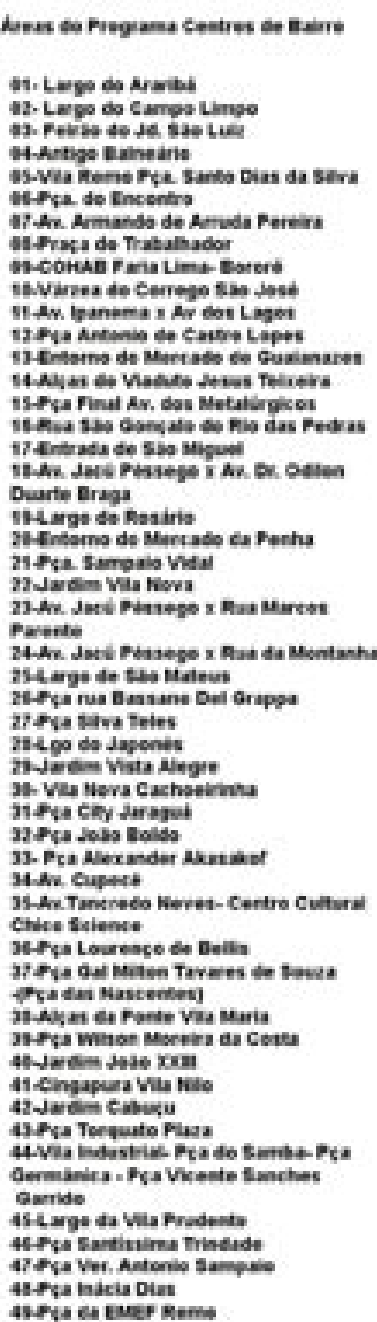

dens te Programe sestres et Evime

Folite to de sovinge

4. Artige e eme inis

neve Dias as serra

vererers

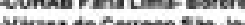

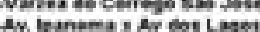

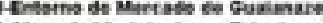

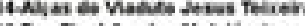

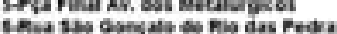

Therte Draga

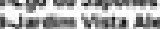

stesest

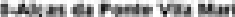

47 Pra Ver. Aatonio Samecos

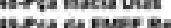


Fig. 37, 38, 39 e 40 Av. Armando de Arruda Pereira

- junho 2003.

Largo do Araribá - outubro 2002.

Largo Campo Limpo - fevereiro 2003.

Feirão do São Luis - junho 2002.

Fotos: Lopez
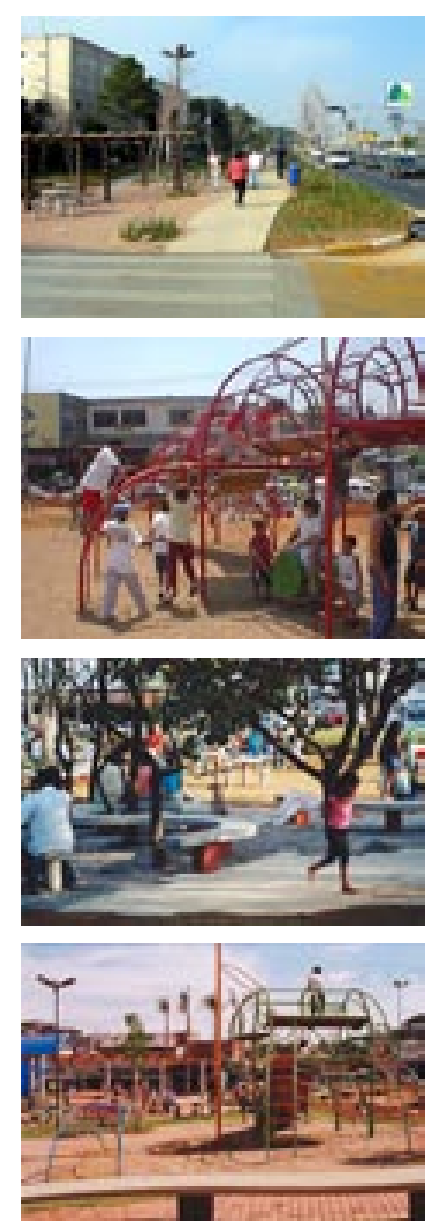

a intervenção, ou a intervenção não se mostrou adequada para aquela área. Isto ocorreu porque os subprefeitos não escolheram as áreas apenas pelos critérios expostos, mas também segundo interesses próprios como: atender reinvidicações de determinada parcela da vizinhança de sua subprefeitura, ocupar uma área de risco de invasão, resolver problemas de drenagem, entre outros exemplos; ou seja, intervenções que facilitassem e valorizassem sua gestão (pessoal) dentro da subprefeitura e que respondessem a determinados setores da comunidade, o que em alguns pontos prejudicou os projetos. (Fig. 36)

Assim as áreas foram divididas pelas zonas norte, sul, leste e oeste da cidade, e para uma maior facilidade na sua implantação, foram organizadas por lotes de licitações:

Lote 1: Zona Sul (Fig. 37, 38, 39 e 40)

Largo do Arariba: $25.264 \mathrm{~m}^{2}$;

Largo do Campo Limpo: $15.000 \mathrm{~m}^{2}$;

Feirão de São Luiz (R. Geraldo Fraga do Oliveira x R. Arraial dos Couros): $5.131 \mathrm{~m}^{2}$;

Praça Santo Dias da Silva: $12.200 \mathrm{~m}^{2}$;

Antigo Balneário (Rua Nicolino Leo x Rua colônia Nova): $6.250 \mathrm{~m}^{2}$;

Praça do Encontro: $4.950 \mathrm{~m}^{2}$;

Praça do Trabalhador: $37.350 \mathrm{~m}^{2}$;

Av. Ipanema x Av. dos Lagos: $27.250 \mathrm{~m}^{2}$;

Áreas verdes do Conj. Hab. Faria Lima (Grajaú): $46.000 \mathrm{~m}^{2}$;

Av. Armando de Arruda Pereira: $30.050 \mathrm{~m}^{2}$, Várzea do Córrego São José: $140.000 \mathrm{~m}^{2}$.

TOTAL: $349.445 \mathrm{~m}^{2}$ 


\section{Lote 2: Zona Leste}

Entorno do Mercado Municipal da Penha: $22.184 \mathrm{~m}^{2}$;

Largo do Rosário: $3850 \mathrm{~m}^{2}$;

Praça Av. Antônio Castro Lopes x R. Guilherme de Oliveira

Sá: $14.500 \mathrm{~m}^{2}$;

Entrada de São Miguel (Av. São Miguel x Av. Jacu

Pêssego): $33.126 \mathrm{~m}^{2}$;

São Gonçalo do Rio das Pedras x Rua Conceição de Almeida: $10.650 \mathrm{~m}^{2}$;

Entorno do Mercado Municipal de Guaianazes: $19.250 \mathrm{~m}^{2}$;

Avenida dos Metalúrgicos: $25.350 \mathrm{~m}^{2}$;

Praça da Mãe Preta: $18.882 \mathrm{~m}^{2}$,

Praça na Vila Jacuí (Rua Maria Santana x rua Oríades): $18.300 \mathrm{~m}^{2}$.

TOTAL: $166.092 \mathrm{~m}^{2}$

\section{Lote 3: Zona Leste}

Largo de São Mateus: $13.479 \mathrm{~m}^{2}$;

Praça Rua Bassano Del Grappa x Av. Mariana de Souza Guerra: $11.350 \mathrm{~m}^{2}$;

Praça Rua Tauro x Rua Solange da Pureza Jardins:

$8.850 \mathrm{~m}^{2}$;

Praça Silva Teles: $4.500 \mathrm{~m}^{2}$;

Praça Sampaio Vidal: $9.000 \mathrm{~m}^{2}$,

Margem da Av. Jacu Pêssego: $36.926 \mathrm{~m}^{2}$.

TOTAL: $84.105 \mathrm{~m}^{2}$

(na página ao lado)

Fig. 41, 42, 43, 44, 45, 46, 47

$$
\text { e } 48 \text {. }
$$

Antonio de Castro Lopes;

Bassano Del Grappa;

Jardim Grimaldi - junho 2003;

Vila Industrial - junho 2003;

Largo de São Mateus - junho

2003;

Praça Sampaio Vidal - junho

2003;

Praça Santíssima Trindade;

Av. dos Metalúrgicos - junho

2003.

Fotos: Lopez 

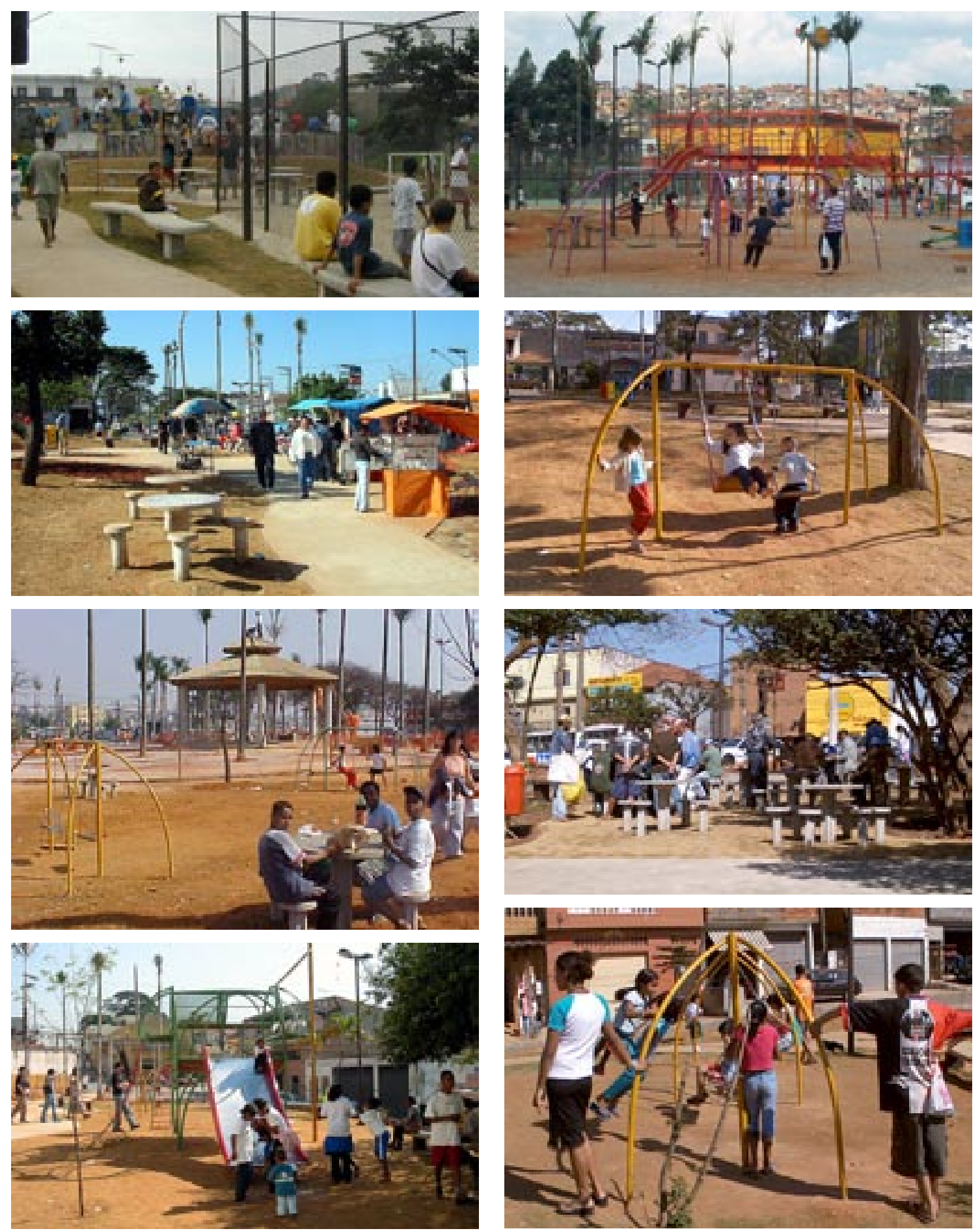


\section{Lote 4: Zonas Norte e Oeste}

Largo do Japonês: $2.300 \mathrm{~m}^{2}$;

Jardim Vista Alegre (Rua Firminópolis x Rua Ibiraiaras):

$6.238 \mathrm{~m}^{2}$;

Largo do jardim Peri: $4.600 \mathrm{~m}^{2}$;

Parque da Vila Nova Cachoeirinha: $53.000 \mathrm{~m}^{2}$;

City Jaraguá (Rua Camilo Zanotti x Estrada de Taipas):

$21.000 \mathrm{~m}^{2}$;

Praça João Boldo: $9.000 \mathrm{~m}^{2}$;

Praça Lourenço de Bellis: $6.842 \mathrm{~m}^{2}$;

Praça General Milton Tavares: $24.799 \mathrm{~m}^{2}$;

Alças da Ponte da Vila Maria: $52.146 \mathrm{~m}^{2}$;

Av. Pres. Tancredo Neves x Rua Abagiba: $13.200 \mathrm{~m}^{2}$;

Av. D. Pedro I.: $22.000 \mathrm{~m}^{2}$;

Av. Cupecê x Rua Antoni Pinho de Azevedo: $19.600 \mathrm{~m}^{2}$,

Praça Alexandre Akasakof: $10.105 \mathrm{~m}^{2}$.

TOTAL: $244.830 \mathrm{~m}^{2}$
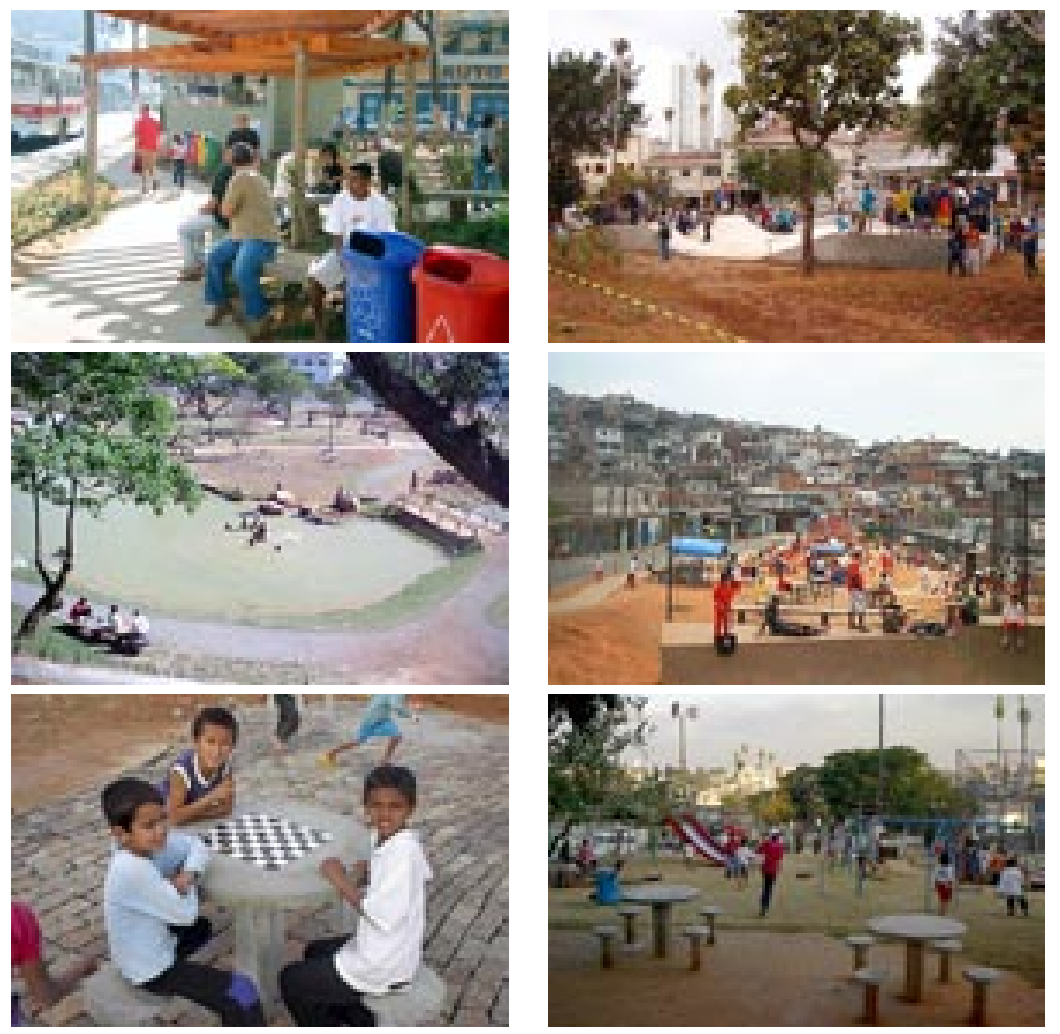

Fig. 49, 50, 51, 52, 53 e 54 .

Largo do Japonês - junho 2003;

Pça Ver Antonio Sampaio

- julho 2003;

Praça Gal. Milton Tavares; Jardim Vista Alegre;

City Jaraguá;

João Boldo.

Fotos: Lopez 


\section{Lote 5: Zonas Oeste, Norte e Leste}

Praça Wilson Moreira da Costa: $13.125 \mathrm{~m}^{2}$;

Jardim João XXIII (R. Nagir Miguel x R. Frei Claude D'Alberville): $40.925 \mathrm{~m}^{2}$; Cingapura Vila Nilo: $12.760 \mathrm{~m}^{2}$;

Jardim Cabuçu (Rua Miguel Lisboa x Rua Dr. Azevedo Lima): $15.710 \mathrm{~m}^{2}$;

Praça Ver. Antonio Sampaio ( Av. Ultramarino x Av. Direitos Humanos): $7.057 \mathrm{~m}^{2}$;

Praça Santíssima Trindade: $6.500 \mathrm{~m}^{2}$;

Rua Braz Leme x Rua Marambaia: $3.810 \mathrm{~m}^{2}$;

Praça Torquato Plaza: $13.896 \mathrm{~m}^{2}$;

Praça Luiz Augusto Campeiro: $10.500 \mathrm{~m}^{2}$;

Praça Padre Damião: $9.000 \mathrm{~m}^{2}$;

Av. Arq. Vilanova Artigas: $18.612 \mathrm{~m}^{2}$;

Praça EMEF Remo ( Rua Alberto Gentili): $12.650 \mathrm{~m}^{2}$,

Praça Inácia Dias: $14.700 \mathrm{~m}^{2}$.

TOTAL: $179.245 \mathrm{~m}^{2}$
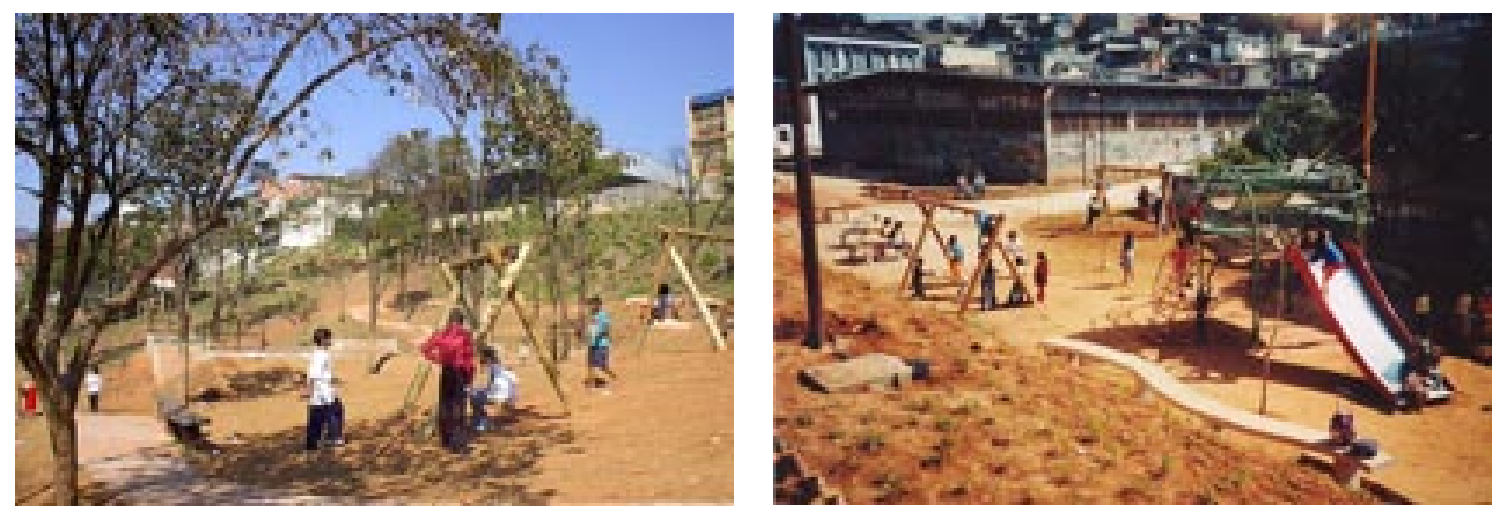

Fig. 55 e 56.

EMEF Remo; João XXXIII.

Fotos: Lopez

(nas páginas seguintes) TAB Relação das praças do Programa Centros de Bairro com suas principais características, entorno, equipamentos implantados, respectivas áreas de intervenção e algumas histórias curiosas. 


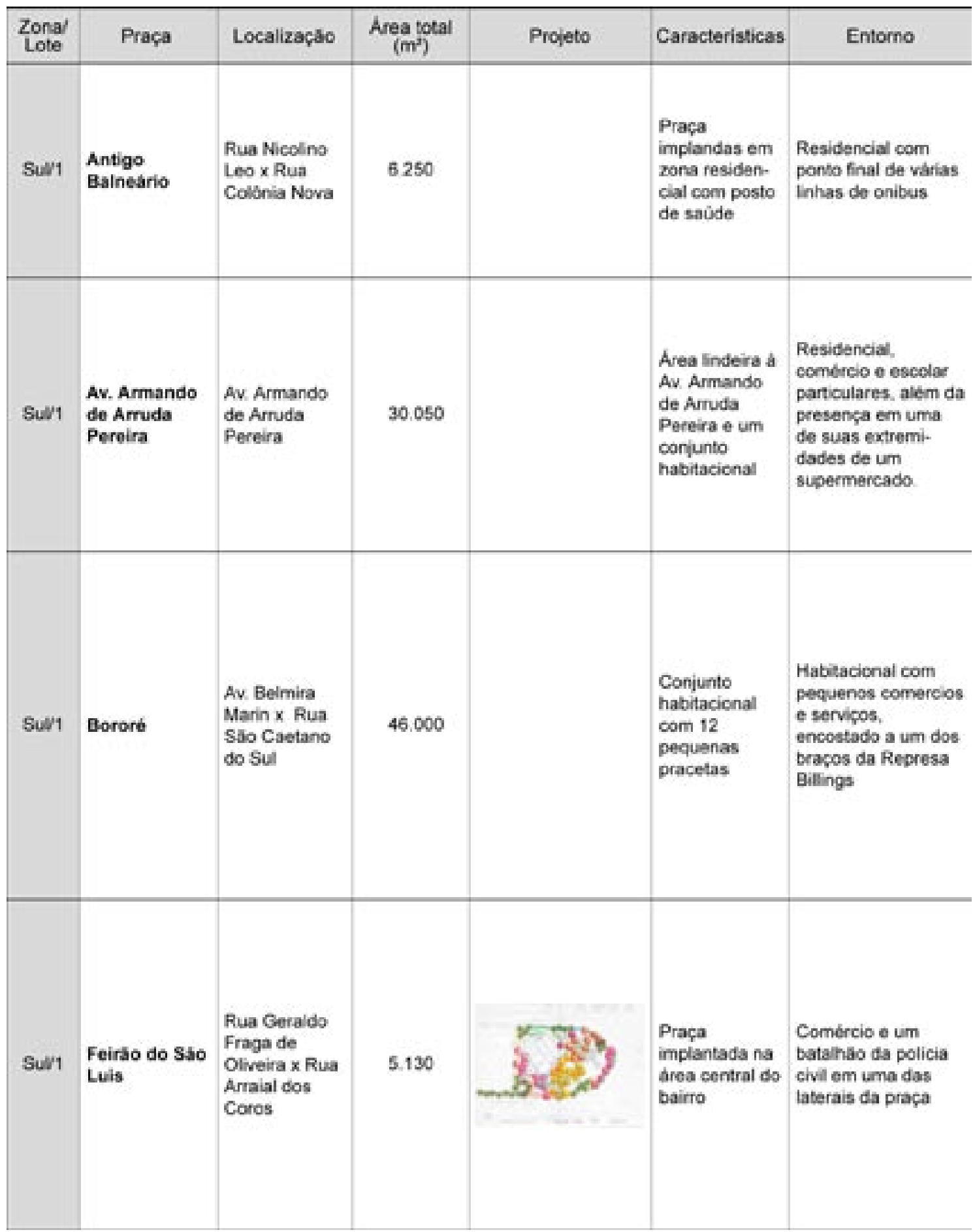




\begin{tabular}{|c|c|c|c|c|}
\hline Equipamentos implantados & Outras Açס̄es & Histórias e Observaçbes & $\begin{array}{l}\text { Fotos do Local } \\
\text { antes/obras }\end{array}$ & $\begin{array}{l}\text { Fotos do Local } \\
\text { depois }\end{array}$ \\
\hline $\begin{array}{l}\text { Quadra peliesportiva. } \\
\text { mini-quadra de areis, pista } \\
\text { se skate. bicecross. } \\
\text { playground, pista de cooper } \\
\text { com equipamertos de } \\
\text { ginastica, laga, estar com } \\
\text { pergolado e estares com } \\
\text { mesas e bancos. }\end{array}$ & $\begin{array}{l}\text { Resoluça de um } \\
\text { problema de drenagem } \\
\text { local com a implantaçlo } \\
\text { do lago foworecendo a } \\
\text { mina d' agua existente. }\end{array}$ & & & \\
\hline $\begin{array}{l}\text { Estares com pergola- } \\
\text { dos, pista de cooper } \\
\text { com aparehos de } \\
\text { gindstica, além de } \\
\text { outros estares com } \\
\text { mesas a bancos }\end{array}$ & 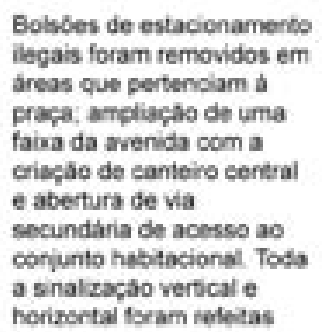 & $\begin{array}{l}\text { Conflito com os } \\
\text { moradores do conjunto } \\
\text { que naso queriam a } \\
\text { implantaçlo da praça }\end{array}$ & & \\
\hline $\begin{array}{l}\text { Quadra poliesportiva, } \\
\text { mini-quadra de areia, } \\
\text { pista de skate, palco } \\
\text { coberto para pequenas } \\
\text { apresentaçoes, } \\
\text { playgrounds, horta } \\
\text { comuniaria, } \\
\text { deco/solarium e vairios } \\
\text { estares com mesas e } \\
\text { bancos }\end{array}$ & 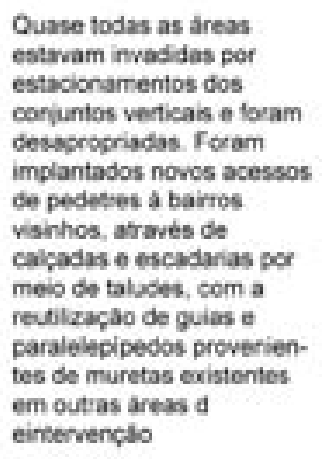 & $\begin{array}{l}\text { Alguns moradores, } \\
\text { dopois da conclusbo } \\
\text { das cbras, vieram } \\
\text { agradecer a valorizaçăo } \\
\text { de seus apartamentos } \\
\text { com as áreas dde } \\
\text { jardins e playgrounds. E } \\
\text { alguns traficantes } \\
\text { ameaçaram o arquiteto } \\
\text { responsàvel por esta } \\
\text { obra de morte }\end{array}$ & & \\
\hline $\begin{array}{l}\text { Quadra poliesportiva, } \\
\text { mini-quadra de areis, } \\
\text { pista de skato, paico } \\
\text { cobreto para pequenas } \\
\text { apresentaçбes, } \\
\text { playground e vários } \\
\text { estares com mesas e } \\
\text { bancos }\end{array}$ & $\begin{array}{l}\text { Frades para impedir a } \\
\text { entrada de veiculos }\end{array}$ & & & te \\
\hline
\end{tabular}




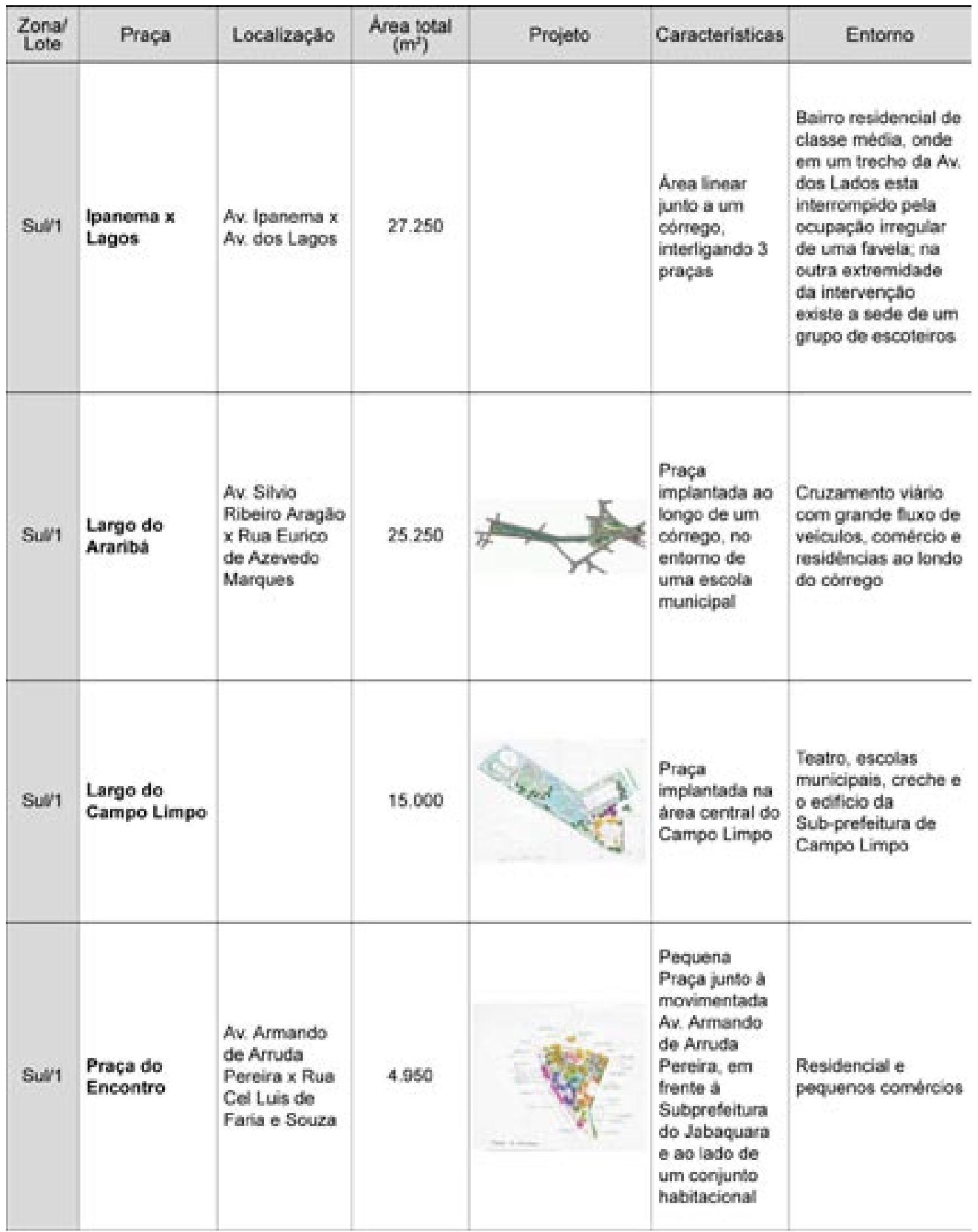




\begin{tabular}{|c|c|c|c|c|}
\hline Equipamentos implantados & Outras Açōes & Histórias e Observaçbes & $\begin{array}{l}\text { Fotos do Local } \\
\text { antes/obras }\end{array}$ & $\begin{array}{l}\text { Fotos do Local } \\
\text { depois }\end{array}$ \\
\hline $\begin{array}{l}\text { Mini quadra de areia, } \\
\text { playgrounds, estar com } \\
\text { pergolado, estares com } \\
\text { mesas a baroos }\end{array}$ & $\begin{array}{l}\text { Foram realizados } \\
\text { trabalhes do contençalo } \\
\text { das margens do córrego } \\
\text { e implantȩăo de pontes } \\
\text { para a travessia de } \\
\text { pedestres. Alem disso } \\
\text { foi aberto trecho do } \\
\text { CDM junto a favela e } \\
\text { incorporado a praça. o } \\
\text { escoteiros ganharam } \\
\text { patio de dpresentables } \\
\text { que tambem foi } \\
\text { incorporado à praça }\end{array}$ & $\begin{array}{l}\text { Como se trata de uma } \\
\text { ares localizads em um } \\
\text { bairro de classe media. } \\
\text { o seu uso b́ bem menos } \\
\text { intenso se comparado a } \\
\text { outras areas de } \\
\text { intervencalo. Ha um } \\
\text { mecalnico que moniou } \\
\text { sua cficina literalmente } \\
\text { na praca e algumas } \\
\text { vezes utilizou parasusos } \\
\text { dos brinquedos para } \\
\text { seus consertos }\end{array}$ & & \\
\hline $\begin{array}{l}\text { Quadra poliesportiva, } \\
\text { mini-quadra de areis, } \\
\text { pistad e skate, } 2 \\
\text { playgrounds, relbgio de } \\
\text { sol, escorrega e vários } \\
\text { estares com mesas e } \\
\text { bancos }\end{array}$ & $\begin{array}{l}\text { Parceira com o CET } \\
\text { com implantaçăo de } \\
\text { novo projeto de } \\
\text { sinalizaçalo vertical e } \\
\text { horizontal minimizando } \\
\text { os conflitos do } \\
\text { cruzamento, Implanta- } \\
\text { çà de nowo projeto de } \\
\text { drenagem e } \\
\text { escoamento de spuas } \\
\text { pluvias, junto a escola }\end{array}$ & $\begin{array}{l}\text { Enquanto estava sendo } \\
\text { implantado o projeto de } \\
\text { drenagem, foram } \\
\text { encontrados um cavalo } \\
\text { e um sota que estavam } \\
\text { obstruindo a canaliza- } \\
\text { çăo do corrego a } \\
\text { prejudicandoa drena- } \\
\text { gem do local }\end{array}$ & & \\
\hline $\begin{array}{l}\text { Quadra poliesportiva, } \\
\text { min-quadra de areis, } \\
\text { pista de skate, palco } \\
\text { cobreto para pequenas } \\
\text { apresentaços, } \\
\text { playground e valrios } \\
\text { estares com mesas e } \\
\text { bancos }\end{array}$ & $\begin{array}{l}\text { Em parceria com o CET, } \\
\text { foram incorporadas a } \\
\text { drea da antiga praca, } \\
\text { duas ruas adjacertes; } \\
\text { amplando e conectando } \\
\text { todas as pequenas } \\
\text { pracetas existemes }\end{array}$ & $\begin{array}{l}\text { Enquanto estarva sendo } \\
\text { implantado o projeto de } \\
\text { drenagem, foram } \\
\text { encontrados um cavalo } \\
\text { e um sota que estavam } \\
\text { obstruindo a canaliza- } \\
\text { çăo do corrego e } \\
\text { prejudicandoa drena- } \\
\text { gem do local }\end{array}$ & & \\
\hline $\begin{array}{l}\text { Quadra de 21, pista de } \\
\text { Skate, playground, estar } \\
\text { com pergolado, alem de } \\
\text { outros estares com } \\
\text { mesas a bancos }\end{array}$ & $\begin{array}{l}\text { Toda a sinalizaçio } \\
\text { vertical e horizontal } \\
\text { foram refeitas }\end{array}$ & $\begin{array}{l}\text { Moradores ficaram } \\
\text { insatisfeitos principal. } \\
\text { mente com a implanta- } \\
\text { ça da quadra } e 21 \\
\text { junto ao seu muro de } \\
\text { divisa }\end{array}$ & & \\
\hline
\end{tabular}




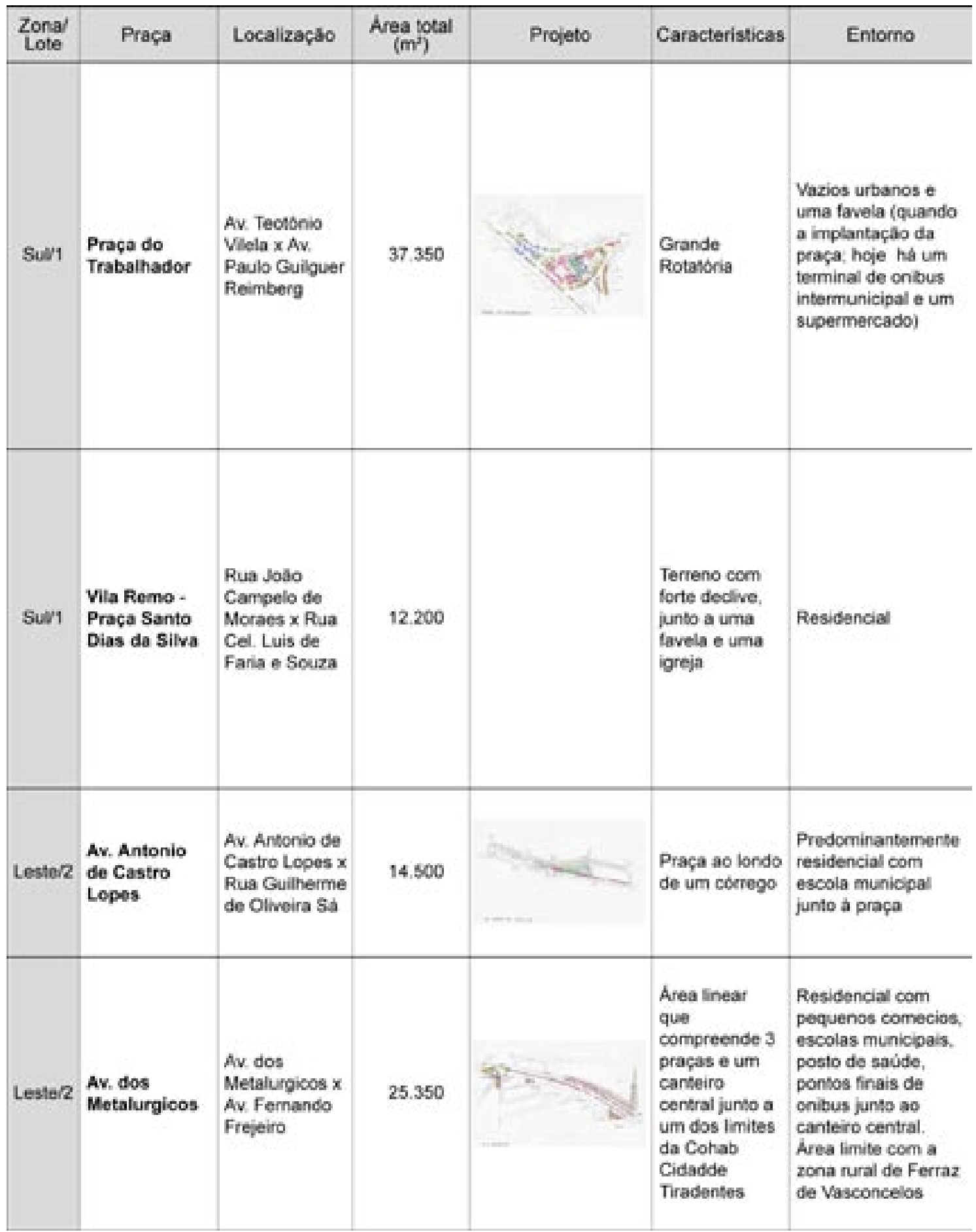




\begin{tabular}{|c|c|c|c|c|}
\hline Equipamentos implantados & Outras Açס̄es & Histórias e Observaçbes & $\begin{array}{l}\text { Fotos do Local } \\
\text { antes/obras }\end{array}$ & $\begin{array}{l}\text { Fotos do Local } \\
\text { depois }\end{array}$ \\
\hline $\begin{array}{l}2 \text { Quadras poliesporti- } \\
\text { vas, } 2 \text { mini-quadras de } \\
\text { areia, pista de skate, } \\
\text { palco para pequenas } \\
\text { apresentaçбes, } \\
\text { playground, pergolados, } \\
\text { pista de cooper oom } \\
\text { equipamentos de } \\
\text { ginastica. estares com } \\
\text { mesas e bancos e um } \\
\text { centro de capacitaçæo } \\
\text { com aulas de } \\
\text { informatica e um } \\
\text { pequeno auditorio }\end{array}$ & $\begin{array}{l}\text { Toda a sinalizaçlo } \\
\text { vertical e horizontal } \\
\text { foram refeitas, aldem de } \\
\text { um acesso a favela } \\
\text { coma reutilicaçà de } \\
\text { guias danificadas e } \\
\text { paralelepipedos de } \\
\text { antigas muretas d } \\
\text { eoutras areas de } \\
\text { intervençâo }\end{array}$ & $\begin{array}{l}\text { Confliso inicial com os } \\
\text { moradores do conjunto } \\
\text { que näo queriam a } \\
\text { implantaço da } \\
\text { prapa. Depois da praça } \\
\text { entregue a SPTrans } \\
\text { teve que amplas o } \\
\text { número de carros das } \\
\text { linhas que passavam } \\
\text { pela praça devido a } \\
\text { grande procura. Nos } \\
\text { primeiros finais de } \\
\text { semana chegaram a ser } \\
\text { contadas } 3.000 \text { pessoss } \\
\text { utulizando a praça }\end{array}$ & te' & \\
\hline $\begin{array}{l}\text { Quadra poliesportiva, } \\
\text { mini-quadra de areis, } \\
\text { pista de skate, palco } \\
\text { coberto para pequenas } \\
\text { apresentaços, } \\
\text { playground, relogio de } \\
\text { sol e estares com } \\
\text { mesas e bancos }\end{array}$ & $\begin{array}{l}\text { Foi fechada uma viela } \\
\text { de acesso, ilegal, } \\
\text { implantada por } \\
\text { mooradores. Tambem } \\
\text { foram implantados } \\
\text { muros de contençäo } \\
\text { para diminuir o } \\
\text { esccamento de dgua e } \\
\text { terra em direçalo a } \\
\text { favela, junto com um } \\
\text { sistema do drenagem } \\
\text { adequado }\end{array}$ & $\begin{array}{l}\text { Como se trata de uma } \\
\text { area localizada em um } \\
\text { bairro de classe media, } \\
\text { o seu uso b́ bem menos } \\
\text { intenso se comparado a } \\
\text { cutras áreas de } \\
\text { intervença. Ha um } \\
\text { mecanico que momou } \\
\text { sua cficina literalmente } \\
\text { na praça a algumas } \\
\text { vezes utlizou parałusos } \\
\text { dos brinquedos para } \\
\text { seus consertos }\end{array}$ & & \\
\hline $\begin{array}{l}\text { Quadra poliesportiva, } \\
\text { mini-quadra de areia, } \\
\text { pista de skate, quadra } \\
\text { de malha e estares com } \\
\text { mesas e bancos }\end{array}$ & $\begin{array}{l}\text { Reduçao do leito } \\
\text { carroçavel de uma das } \\
\text { ruas addjacentes para a } \\
\text { amplisçào da área da } \\
\text { praça }\end{array}$ & $\begin{array}{l}\text { Outra area de grande } \\
\text { sucesso com centenas } \\
\text { de pessoas utilizando a } \\
\text { prasa nos finais do } \\
\text { semana principalmente }\end{array}$ & & \\
\hline $\begin{array}{l}\text { Quadra poliesportiva, } \\
\text { playgrounds, pista de } \\
\text { skate, posto policial e } \\
\text { estares com mesas e } \\
\text { bancos }\end{array}$ & $\begin{array}{l}\text { Reestruturaçao do } \\
\text { sistema viário }\end{array}$ & & & \\
\hline
\end{tabular}




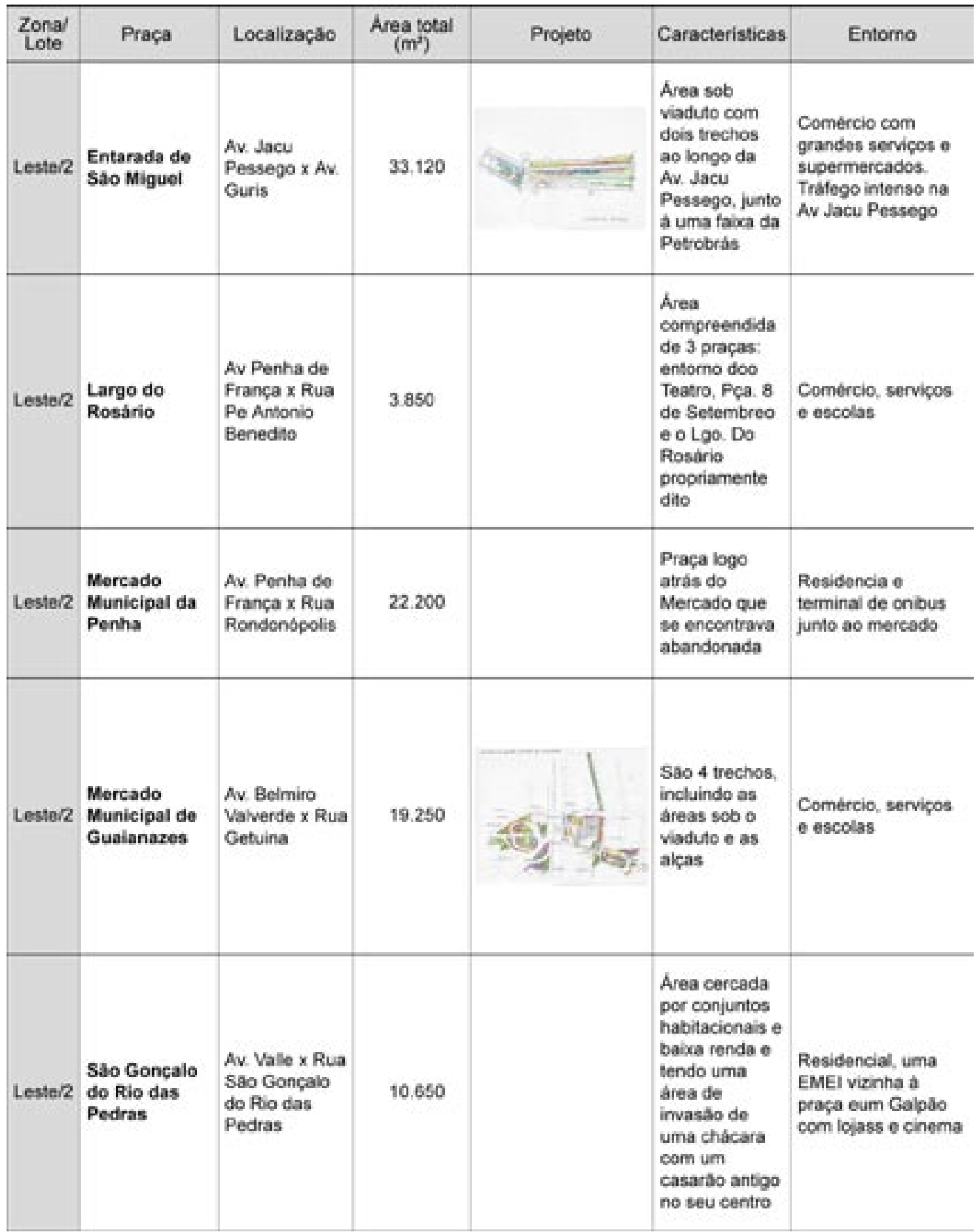




\begin{tabular}{|c|c|c|c|c|}
\hline Equipamentos implantados & Outras Açסes & Histórias e Observaçbes & $\begin{array}{l}\text { Fotos do Local } \\
\text { antes/obras }\end{array}$ & $\begin{array}{l}\text { Fotos do Local } \\
\text { depois }\end{array}$ \\
\hline $\begin{array}{l}\text { Quadra poliesportiva, } \\
\text { pista de skate, } \\
\text { playground, parede de } \\
\text { escalada, estares com } \\
\text { mesas e bancos e pista } \\
\text { de caminhada }\end{array}$ & & $\begin{array}{l}\text { O acesso dificil á praça } \\
\text { devido ao trátego } \\
\text { intenso de veiculos } \\
\text { prejudica o seu uso }\end{array}$ & & \\
\hline $\begin{array}{l}\text { Playground, palco para } \\
\text { pequenas apresenta- } \\
\text { p̧es, posto policial e } \\
\text { estares com mesas e } \\
\text { bancos }\end{array}$ & $\begin{array}{l}\text { Foram implantados } \\
\text { acessos para deficien. } \\
\text { tes fisicos ao teatro, que } \\
\text { teve tambem sua } \\
\text { fachada restaurada }\end{array}$ & $\begin{array}{l}\text { As } 3 \text { praças possuem } \\
\text { usos bem diferenciados. } \\
\text { Há problemas com o } \\
\text { dimensionamneto das } \\
\text { passeios na Pça } 8 \text { de } \\
\text { setembro e conflitos } \\
\text { como DPH no Lgo do } \\
\text { Rosario }\end{array}$ & & \\
\hline $\begin{array}{l}\text { Playground, pista de } \\
\text { skate, estares com } \\
\text { mesas o bancos }\end{array}$ & & $\begin{array}{l}\text { Skatistas contrataram } \\
\text { uma pessoa para tomar } \\
\text { conta da pista }\end{array}$ & & \\
\hline $\begin{array}{l}\text { Playground, palco para } \\
\text { pequenas apresenta. } \\
\text { ples, quadra polies. } \\
\text { portiva, pista de skate e } \\
\text { estares com mesas a } \\
\text { bancos }\end{array}$ & $\begin{array}{l}\text { Reapropisaçbo da área } \\
\text { de estacionamento } \\
\text { existente sob o viaduAto } \\
\text { Foram feitos trabalhos } \\
\text { de cotençalo das } \\
\text { margens do córego }\end{array}$ & $\begin{array}{l}\text { Conflisos com os } 1000 \\
\text { ambulantes existentes } \\
\text { na àrea. A praça lota } \\
\text { aos sabados a noite } \\
\text { devido a um bar com } \\
\text { música ao vivo } \\
\text { localizado na frente da } \\
\text { praça. Neste local uma } \\
\text { palmeira de } 10 \text { metros } \\
\text { de tronco foi roubada } \\
\text { durante a noite }\end{array}$ & & \\
\hline $\begin{array}{l}\text { Reforma do Campo de } \\
\text { Futebol existente, } \\
\text { playground, estares com } \\
\text { mesas e banoos e posto } \\
\text { policial }\end{array}$ & $\begin{array}{l}\text { Reapropriaça da } \\
\text { invasdo e integraçlo da } \\
\text { chacara a praça. O } \\
\text { portao do entrada e } \\
\text { saida da EMEl voltou-se } \\
\text { para a praça }\end{array}$ & $\begin{array}{l}\text { As pessoas que tomam } \\
\text { conta"do campo de } \\
\text { futebol, nào queriam a } \\
\text { implantaclo do } \\
\text { playground }\end{array}$ & 1 & \\
\hline
\end{tabular}




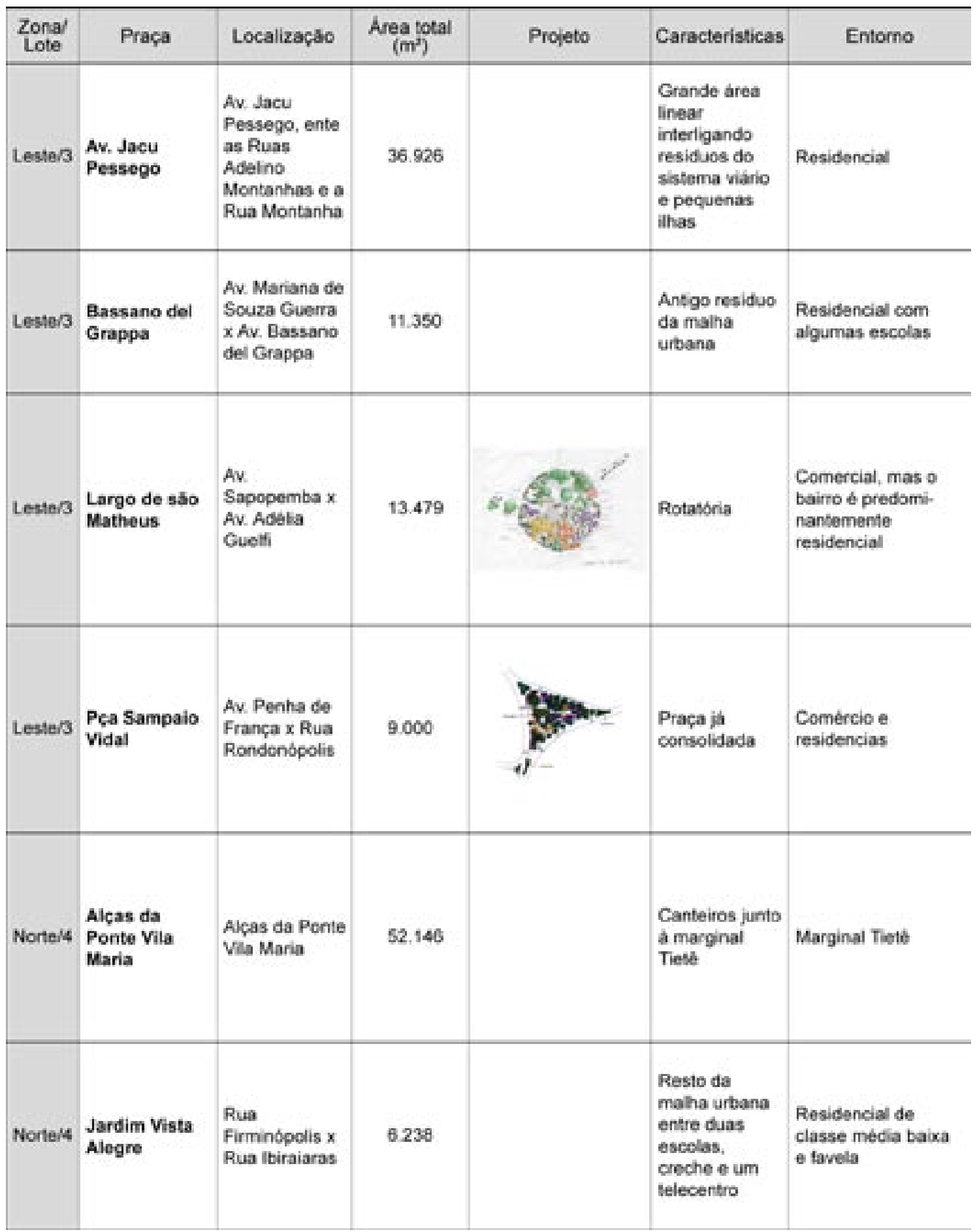




\begin{tabular}{|c|c|c|c|c|}
\hline Equipamentos implantados & Outras Açס̄es & Histórias e Observaçoes & $\begin{array}{l}\text { Fotos do Local } \\
\text { antes/obras }\end{array}$ & $\begin{array}{l}\text { Fotos do Local } \\
\text { depois }\end{array}$ \\
\hline $\begin{array}{l}\text { Quadras poliesportivas, } \\
\text { mini quadra de areia, } \\
\text { playgrouns, reforma do } \\
\text { campo de futebol } \\
\text { existente e estares com } \\
\text { mesas e bancos }\end{array}$ & $\begin{array}{l}\text { Reapropriaçao de } \\
\text { trechos invadidos por } \\
\text { favela }\end{array}$ & $\begin{array}{l}\text { A obra foi roubada } \\
\text { varias vezes e em uma } \\
\text { delas os ladróes } \\
\text { prenderam a agrónoma } \\
\text { responsável por esta } \\
\text { àrea e levaram a } \\
\text { retroescavadeira }\end{array}$ & & \\
\hline $\begin{array}{l}\text { Quadra poliesportiva, } \\
\text { playgrounds, pista de } \\
\text { skate, posto policial e } \\
\text { estares com mesas e } \\
\text { bancos }\end{array}$ & & & & \\
\hline $\begin{array}{l}\text { Playground, reforma do } \\
\text { coreto existente, pista } \\
\text { de cooper com } \\
\text { equipamentos de } \\
\text { gindstica, eatares com } \\
\text { mesas e bancos }\end{array}$ & $\begin{array}{l}\text { Trabalhos de moviman- } \\
\text { taçalo de terra foram } \\
\text { realizados coma } \\
\text { formaçäo de pequenas } \\
\text { bacias de captaçalo de } \\
\text { bguas pluviais, } \\
\text { favorecendo a drena- } \\
\text { gem e a irrigaçăo dos } \\
\text { canteiros" }\end{array}$ & & & \\
\hline $\begin{array}{l}\text { Playground, posto } \\
\text { policial, estares com } \\
\text { mesas e baroos, palco } \\
\text { para pequenas } \\
\text { apresentaçōes }\end{array}$ & $\begin{array}{l}\text { Foram criadas baias de } \\
\text { estacionamento no } \\
\text { entorno da praça }\end{array}$ & $\begin{array}{l}\text { A praça e muito ublizada } \\
\text { por idosos para o jogo } \\
\text { de domino e damas nas } \\
\text { mesas instalada. } \\
\text { Tambem salo realadas } \\
\text { aulas de ginástica } \\
\text { matinais para a terceira } \\
\text { idade }\end{array}$ & & \\
\hline $\begin{array}{l}\text { Passeio e acessos por } \\
\text { escadarias }\end{array}$ & & $\begin{array}{l}\text { As intervençbes năo } \\
\text { tiveram exito ou foramm } \\
\text { inadequadas para esta } \\
\text { area. Hoje pratcamente } \\
\text { nso s epode perceber } \\
\text { que houve a intervença } \\
\text { e o local encontra-se } \\
\text { abandonado }\end{array}$ & & \\
\hline $\begin{array}{l}\text { Quadra poliesportiva, } \\
\text { mini quadra de areia. } \\
\text { playground e estares } \\
\text { com mesas e bancos }\end{array}$ & $\begin{array}{l}\text { Foi implantado un } \\
\text { sistema de drenagem } \\
\text { em toda a área, } \\
\text { resolvendo um } \\
\text { problema de inundaçóes } \\
\text { constantes pelas âguas } \\
\text { pluviais }\end{array}$ & $\begin{array}{l}\text { Neste local, depois de } \\
\text { alguns meses da obra } \\
\text { entregue. os brinquedos } \\
\text { foram serrados aos } \\
\text { poucos para a venda do } \\
\text { ferro }\end{array}$ & & \\
\hline
\end{tabular}




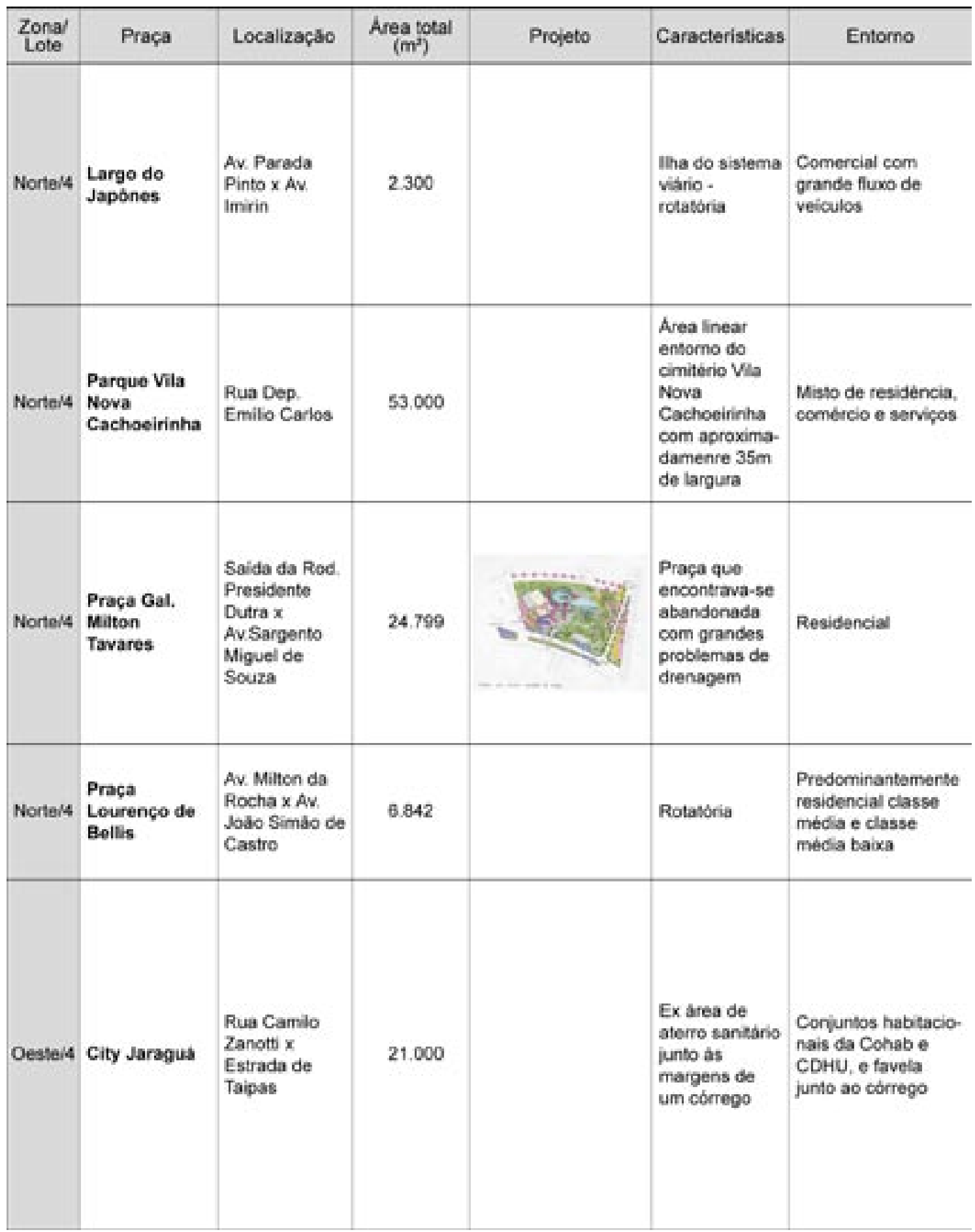




\begin{tabular}{|c|c|c|c|c|}
\hline Equipamentos implantados & Outras Açס̄es & Histórias e Observaçbes & $\begin{array}{l}\text { Fotos do Local } \\
\text { antes/obras }\end{array}$ & $\begin{array}{l}\text { Fotos do Local } \\
\text { depols }\end{array}$ \\
\hline $\begin{array}{l}\text { Estar com pergolado, } \\
\text { mesas e banoos }\end{array}$ & $\begin{array}{l}\text { Foi implantado un novo } \\
\text { projeto do sistema } \\
\text { viagrio, ampliando em } \\
\text { alguns casos o leito } \\
\text { carrocavel da ruas } \\
\text { adjacente e o angulo } \\
\text { das esquinas, visando } \\
\text { minimizar o confito } \\
\text { entre pedrstre e veiculo }\end{array}$ & $\begin{array}{l}\text { O comercio do entorno } \\
\text { nào quaria apraça e } \\
\text { houveram grandes } \\
\text { conflitos como posto de } \\
\text { gasolina de uma das } \\
\text { esquinas, que alegava } \\
\text { ter sido prejudicado com } \\
\text { o novo àngulo da } \\
\text { curvatura da esquina e } \\
\text { a intervençao na praça }\end{array}$ & & \\
\hline $\begin{array}{l}\text { Playground com estares } \\
\text { de mesas e bancos. } \\
\text { pista de cooper com } \\
\text { equipamentos do } \\
\text { gindstica }\end{array}$ & & $\begin{array}{l}\text { Há grande número do } \\
\text { usuários principalmente } \\
\text { nos finais de semana }\end{array}$ & & \\
\hline $\begin{array}{l}\text { Quadras poliesportivas, } \\
\text { mini quadras de areia, } \\
\text { playground, pista de } \\
\text { skate, lago com } \\
\text { esculuras da artista } \\
\text { Amelia Toledo, pista de } \\
\text { cooper com equipa- } \\
\text { meentcs de ginastica. } \\
\text { estares com mesas e } \\
\text { bancos }\end{array}$ & $\begin{array}{l}\text { Os "problemas de } \\
\text { drenagem" foram } \\
\text { resolvides coma } \\
\text { implantaça do lago, na } \\
\text { verdade existiam } 5 \\
\text { nascentes que } \\
\text { afloravam neste local e } \\
\text { causavam transtomos } \\
\text { com a dgua }\end{array}$ & $\begin{array}{l}\text { A praça atrai usuarios } \\
\text { dos bairros vizinhos e } \\
\text { pessoas que vem de } \\
\text { carro de todo a regajo }\end{array}$ & & \\
\hline $\begin{array}{l}\text { Passeios e estares com } \\
\text { mesas e bancos }\end{array}$ & $\begin{array}{l}\text { Foram feitas atteraçoes } \\
\text { do sistema viário }\end{array}$ & & & $r$ \\
\hline $\begin{array}{l}3 \text { Quadras poliesportj- } \\
\text { vas, } 2 \text { mini quadras de } \\
\text { areia, playgroundd, } \\
\text { bicecross, pista de } \\
\text { skate-nâo concluida }\end{array}$ & & $\begin{array}{l}\text { No inicio eram } 65 \\
\text { barracos na favela que } \\
\text { teriam as failias } \\
\text { relocadas nos conjurtos } \\
\text { habitacionais do } \\
\text { entorno. Com o inicio } \\
\text { das cbras, os madeintes } \\
\text { foram roubados } 3 \text { vezes } \\
\text { para a construça de } \\
\text { novos barracos, mesmo } \\
\text { estando furados com } \\
\text { serras copo, e ao fim ja } \\
\text { existiam } 250 \text { barracos, } \\
\text { sendo que parte nio } \\
\text { conseguiu ser relocada }\end{array}$ & & \\
\hline
\end{tabular}




\begin{tabular}{|c|c|c|c|c|c|c|}
\hline $\begin{array}{l}\text { Zona' } \\
\text { Lote }\end{array}$ & Praça & Localização & $\begin{array}{c}\text { Area total } \\
\left(\mathrm{m}^{2}\right)\end{array}$ & Projeto & Caracteristicas & Entorno \\
\hline Oestei4 & $\begin{array}{l}\text { Praça Joj̄o } \\
\text { Boldo }\end{array}$ & $\begin{array}{l}\text { Praça Josto } \\
\text { Boldo }\end{array}$ & 9.000 & $\phi$ & $\begin{array}{l}\text { Praça ja } \\
\text { existente }\end{array}$ & $\begin{array}{l}\text { Residencial comuma } \\
\text { EMEI e uma EMEF } \\
\text { vizinhas à praça }\end{array}$ \\
\hline Sulv4 & $\begin{array}{l}\text { Praça } \\
\text { Tancredo } \\
\text { Neves }\end{array}$ & $\begin{array}{l}\text { Praça } \\
\text { Tancredo } \\
\text { Neves }\end{array}$ & 13.200 & & $\begin{array}{l}\text { Praça entorno } \\
\text { junto a um } \\
\text { centro } \\
\text { comnunitario } \\
\text { da prefeitura e } \\
\text { teatro }\end{array}$ & $\begin{array}{l}\text { Residencial com } \\
\text { areas de combrcio } \\
\text { junto a Av. Tancredo } \\
\text { Neves }\end{array}$ \\
\hline Norters & $\begin{array}{l}\text { Jardim } \\
\text { Cabuçu }\end{array}$ & $\begin{array}{l}\text { Rua Miguel } \\
\text { Arrojado } \\
\text { Lisboa x Rua } \\
\text { Dr. Azrevedo } \\
\text { Lima }\end{array}$ & 15.710 & & $\begin{array}{l}\text { Terreno baldio } \\
\text { utilizado como } \\
\text { bota-fora }\end{array}$ & $\begin{array}{l}\text { Divisa em uma das } \\
\text { extremidades com } \\
\text { Guarulhos. Zona } \\
\text { residencial de classe } \\
\text { baixa e escolas }\end{array}$ \\
\hline Norteis & Vila Nilo & $\begin{array}{l}\text { Km } 86 \text { Rod. } \\
\text { Fernas Dias x } \\
\text { Rua Mancel } \\
\text { Femandes } \\
\text { Silva }\end{array}$ & 12.760 & & $\begin{array}{l}\text { Area junto ao } \\
\text { Cingapura Vila } \\
\text { Nile }\end{array}$ & $\begin{array}{l}\text { COHAB Vila Nilo e } \\
\text { farvelas em } \\
\text { urbanzapio }\end{array}$ \\
\hline Norte/5 & $\begin{array}{l}\text { Santissima } \\
\text { Trindade }\end{array}$ & $\begin{array}{l}\text { Rua Abura } x \\
\text { Rua Zeze } \\
\text { Leoni }\end{array}$ & 6.500 & & Praça & $\begin{array}{l}\text { Area residenciald de } \\
\text { classe mecia }\end{array}$ \\
\hline Oesteis & EMEF Remo & $\begin{array}{l}\text { Rua Aberto } \\
\text { Gentili x Rua } \\
\text { Dionizio } \\
\text { Bellarte }\end{array}$ & 12.650 & 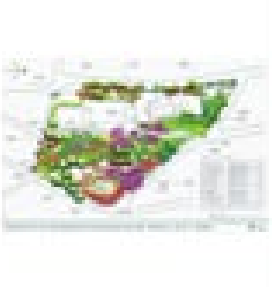 & $\begin{array}{l}\text { Compreende } \\
\text { duas praças: } \\
\text { Pca Alberto } \\
\text { Pereira de } \\
\text { Castro a Pca } \\
\text { Vereador } \\
\text { Antonio } \\
\text { Sampaio }\end{array}$ & $\begin{array}{l}\text { Residencial de } \\
\text { classe meclia e uma } \\
\text { escola vizinha a } \\
\text { praca }\end{array}$ \\
\hline
\end{tabular}




\begin{tabular}{|c|c|c|c|c|}
\hline Equipamentos implantados & Outras Açס̄es & Histórias e Observaçbes & $\begin{array}{l}\text { Fotos do Local } \\
\text { antes/obras }\end{array}$ & $\begin{array}{l}\text { Fotos do Local } \\
\text { depois }\end{array}$ \\
\hline $\begin{array}{l}\text { Qusdra policsportiva, } \\
\text { pista de skate, } \\
\text { playground, estares com } \\
\text { mesas e bancos }\end{array}$ & & & & \\
\hline $\begin{array}{l}\text { Quadra poliesportiva, } \\
\text { mini quadra de areia, } \\
\text { palco coberto para } \\
\text { pequenas apresenta- } \\
\text { ples, bicecross e } \\
\text { estares com mesas e } \\
\text { bancos }\end{array}$ & $\begin{array}{l}\text { A fachada do Centro } \\
\text { comunitario foil } \\
\text { restaurada }\end{array}$ & $\begin{array}{l}\text { Houve um ttrabalho de } \\
\text { reciclagem de pneus } \\
\text { para contençlo de } \\
\text { taludes do entomo da } \\
\text { pracra }\end{array}$ & & \\
\hline $\begin{array}{l}\text { Quadra poliesportiva, } 2 \\
\text { mini quadras de areia, } \\
\text { pista de skate, } \\
\text { playground, pista de } \\
\text { cocper, estares com } \\
\text { mesas e bancos e } \\
\text { lelecentro }\end{array}$ & $\begin{array}{l}\text { A area fol escoinida pelo } \\
\text { suprefoito para conter } \\
\text { invasces de tavelas }\end{array}$ & $\begin{array}{l}\text { Comenta-se no entorno } \\
\text { que o corrego Cabucu, } \\
\text { neste trecho da praça, } \\
\text { serve como desova de } \\
\text { corpos }\end{array}$ & & \\
\hline $\begin{array}{l}\text { Quadra poliesportiva, } \\
\text { pista de skate, } \\
\text { playground e estares } \\
\text { com mesas e bancos }\end{array}$ & $\begin{array}{l}\text { A area foi escolhida pelo } \\
\text { suprefeito para conter } \\
\text { invasces de favelas }\end{array}$ & $\begin{array}{l}\text { Hoje a ărea encontra-se } \\
\text { completamente } \\
\text { abandonada e sem } \\
\text { anutençato, grande parte } \\
\text { da intervençato fol } \\
\text { perdida }\end{array}$ & & \\
\hline $\begin{array}{l}\text { Quadra poliesportiva, } \\
\text { pista de skate, } \\
\text { playground e estares } \\
\text { com mesas e bancos }\end{array}$ & $\begin{array}{l}\text { Uma nua foi fechada e } \\
\text { incorporada à praça }\end{array}$ & & & \\
\hline $\begin{array}{l}\text { Quadra poliesportiva, } \\
\text { bicecross, playground, } \\
\text { pista de skate e estares } \\
\text { com mesas e bancos }\end{array}$ & $\begin{array}{l}\text { A área foi escolhida pelo } \\
\text { suprefeito para conter } \\
\text { invasces de favelas }\end{array}$ & & & \\
\hline
\end{tabular}




\begin{tabular}{|c|c|c|c|c|c|c|}
\hline $\begin{array}{l}\text { Zonal } \\
\text { Lote }\end{array}$ & Praça & Localizaçằ & $\begin{array}{c}\text { Area yotal } \\
\left(\mathrm{m}^{2}\right)\end{array}$ & Projeto & Caracteristicas & Entorno \\
\hline Oester5 & Joảo XXIIII & $\begin{array}{l}\text { Rua Nazir } \\
\text { Miguel } \times \text { Rua } \\
\text { Pe Jorge Benci }\end{array}$ & 40.925 & & $\begin{array}{l}\text { Terreno balkio } \\
\text { ocupado por } \\
\text { um galpas } \\
\text { abandonado }\end{array}$ & $\begin{array}{l}\text { Residencial de baixs } \\
\text { renda com terminal } \\
\text { de cnibus e uma } \\
\text { adufora da Sabesp }\end{array}$ \\
\hline Oeste/5 & $\begin{array}{l}\text { Pça Wilson } \\
\text { Moreira da } \\
\text { Costa }\end{array}$ & $\begin{array}{l}\text { Rua Milton } \\
\text { Soares } x \text { Rua } \\
\text { Dr. Paulo } \\
\text { Carvalho } \\
\text { Ferreira }\end{array}$ & 13,125 & 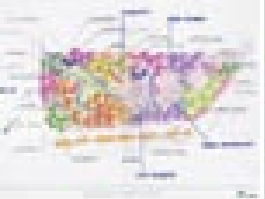 & Praça & $\begin{array}{l}\text { Comércio, escola, } \\
\text { residencias classe } \\
\text { media e favela }\end{array}$ \\
\hline Lesta/5 & Vila Industrial & $\begin{array}{l}\text { Av. Maestro } \\
\text { Joato Evange- } \\
\text { lista } \times \text { Rua } \\
\text { Antonio Alves } \\
\text { Santos }\end{array}$ & 10.500 & & $\begin{array}{l}\text { Compreende } 3 \\
\text { praças Pça. } \\
\text { luis augusto } \\
\text { Canteiro, Pça } \\
\text { Germanica e } \\
\text { Pca. Vicente } \\
\text { Sannhes } \\
\text { Garrido }\end{array}$ & $\begin{array}{l}\text { Bsirro consolidado } \\
\text { predominantemente } \\
\text { residencial com } \\
\text { esclas e alguns } \\
\text { servicgs }\end{array}$ \\
\hline Leste/5 & Pe. Damiăo & $\begin{array}{l}\text { Rua Pacheco } \\
\text { Chaves x Rua } \\
\text { Ingai }\end{array}$ & 9.000 & $\frac{x^{2}}{2=5}$ & $\begin{array}{l}\text { Praca - tha } \\
\text { central }\end{array}$ & $\begin{array}{l}\text { Residencial de } \\
\text { classe media }\end{array}$ \\
\hline Leste/5 & $\begin{array}{l}\text { Vor, Antonio } \\
\text { Sampaio }\end{array}$ & $\begin{array}{l}\text { Av. Ultramarino } \\
\times \text { Av. Dinetos } \\
\text { Humanos }\end{array}$ & 7.057 & & $\begin{array}{l}\text { Compreende } \\
\text { duas areas } \\
\text { residuais do } \\
\text { traçado urbano }\end{array}$ & $\begin{array}{l}\text { Mista de comercio e } \\
\text { residéncias }\end{array}$ \\
\hline Leste/5 & $\begin{array}{l}\text { Pşa. Torquato } \\
\text { Plaza }\end{array}$ & $\begin{array}{l}\text { Av. } \\
\text { Sapopemba } x \\
\text { Rua Leandro } \\
\text { Bispo de } \\
\text { Oliveira }\end{array}$ & 13.896 & & 2 Praças & $\begin{array}{l}\text { Bsirro residencial de } \\
\text { classe modia, no } \\
\text { entcrno com } \\
\text { biblioteca, escola, } \\
\text { creche e comercio }\end{array}$ \\
\hline
\end{tabular}




\begin{tabular}{|c|c|c|c|c|}
\hline Equipamentos implantados & Outras Açōes & Histórias e Observaçoes & $\begin{array}{l}\text { Fotos do Local } \\
\text { antes/obras }\end{array}$ & $\begin{array}{l}\text { Fotos do Local } \\
\text { depois }\end{array}$ \\
\hline $\begin{array}{l}\text { Campo de futebol, pista } \\
\text { de skate, quadra } \\
\text { poliesportiva. } \\
\text { playground, estares com } \\
\text { mesas e barcos e } \\
\text { centro comunitario }\end{array}$ & $\begin{array}{l}\text { O galpäo abandonado } \\
\text { foi transformado em } \\
\text { centro comunitario e foi } \\
\text { implantado um sistema } \\
\text { de drenagem adecuado } \\
\text { por toda a area }\end{array}$ & $\begin{array}{l}\text { Apoio total da } \\
\text { vizinhança }\end{array}$ & & \\
\hline $\begin{array}{l}\text { Quadra poliesportiva, } \\
\text { mini quadra de areia, } \\
\text { pista de skate, palco } \\
\text { coberto, pista de cooper } \\
\text { e estares com mesas e } \\
\text { bancos }\end{array}$ & $\begin{array}{l}\text { Fechamnoto do uma rua } \\
\text { ligandoa escola à praça, } \\
\text { e alrgamento da } \\
\text { avenida com criaçalo de } \\
\text { canteiro central }\end{array}$ & & & \\
\hline $\begin{array}{l}\text { Qusdra poliesportiva, } \\
\text { pista de skate. } \\
\text { playgrounds, palco } \\
\text { coberto e estares com } \\
\text { mesas e bancos }\end{array}$ & & $\begin{array}{l}\text { Apoio total da } \\
\text { vizinhança }\end{array}$ & & \\
\hline $\begin{array}{l}\text { Estares com mesas e } \\
\text { bancos }\end{array}$ & & $\begin{array}{l}\text { Apoio dos idosos } \\
\text { frequentadores da area }\end{array}$ & & \\
\hline $\begin{array}{l}\text { Quadra poliesportiva, } \\
\text { pista de skate. } \\
\text { playground, posto } \\
\text { policial e estares com } \\
\text { mesas e bancos }\end{array}$ & & & & \\
\hline $\begin{array}{l}\text { Quadra 21, mini quadra } \\
\text { de areia, posto policial, } \\
\text { pista de skate e estares } \\
\text { com mesas e bancos }\end{array}$ & & $\begin{array}{l}\text { Area muito utilizada } \\
\text { principalmente nos } \\
\text { finais de semana, } \\
\text { reaizacto de uma } \\
\text { feirinha d e artesanato } \\
\text { depois da intervençao }\end{array}$ & & \\
\hline
\end{tabular}




\section{A e I a b o r a çã o d o s \\ projetos}

Elaboradas pelos coordenadores do programa, algumas diretrizes se tornaram presentes em todas as intervenções.

A biodiversidade como fator de qualidade de vida urbana foi um dos elementos norteadores do projeto destes espaços. Optou-se pela implantação de manchas de espécies arbóreas pouco encontradas na cidade e na maioria das vezes nativas, que introduzidas juntamente com espécies arbustivas e de forrações proporcionariam flores, cores, texturas, movimentos e aromas.

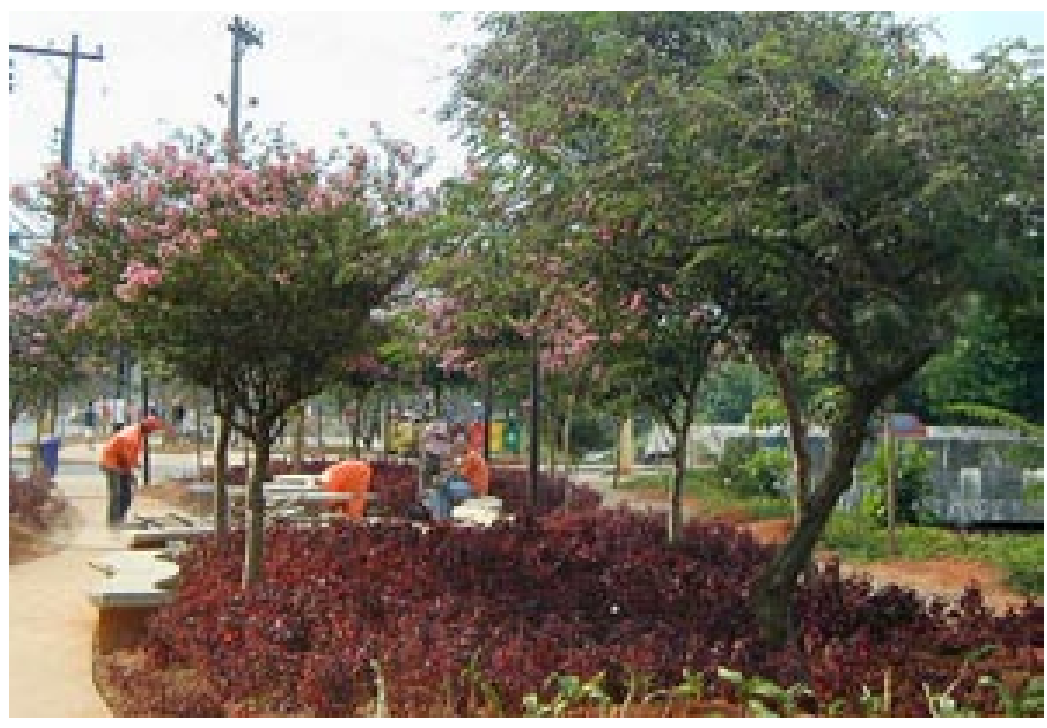

Outra consideração permanente destes projetos foi a ampliação das áreas permeabilizadas (cerca de $70 \%$ de cada área projetada) tentando contribuir, apesar de maneira singela, com a microdrenagem local através da implantação de bacias de captação de água formadas a partir da movimentação de terra dos canteiros. Isso facilitaria a retenção de água e sua absorção pela vegetação; aumentando assim o período de irrigação natural dos canteiros e minimizando pontualmente a questão da drenagem das águas pluviais.
Fig. 57. Resedás em flor

(Largestroenia indica) sobre maciços de Iresine (Iresine herbestii) e Crino rosa (Crinum procerum) na Praça da Rua Antonio de Castro Lopes. Utilização de espécies rústicas, preferencialmente nativas para facilitar a manutenção. Algumas árvores ornamentais, frutíferas palmeiras foram plantadas com um porte adulto para marcar as ares de intervenções (espécies que tinham um valor mais acessível em relação a espécies nativas mais nobres como Jacarandás, Pau-Ferros, entre outras, que foram plantadas num porte menor). Observa-se uma preocupação com o trabalho de texturas, volume e cores nos canteiros de arbustos e forrações, que muitas vezes rebatiam as cores das floradas dos maciços arbóreos. 
Fig. 58. Foto do Feirão de São Luis - Zona Sul - antes da intervenção a área estava ocupada por estacionamento

- irregular - do batalhão da polícia civil Fonte: EMURB

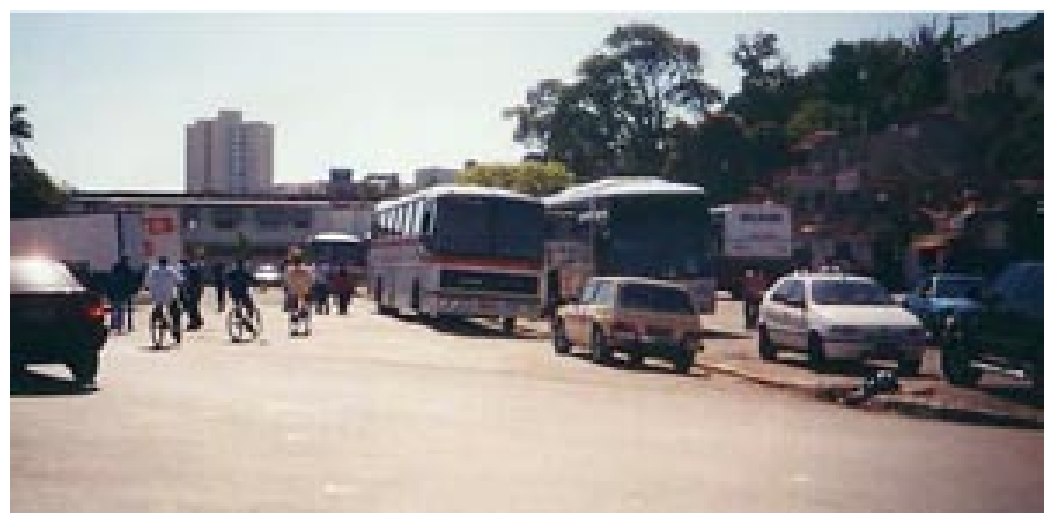

Fig. 59 e 60. Feirão de São Luis após as intervenções. Fotos: Lopez, 2003

(abaixo) Fig. 61. Largo do Rosário - Penha, Zona Leste2004. Equívocos de projeto em áreas de grande fluxo de pedestres e a insistências em retirar o pedestre do meio fio para melhorar sua "segurança", contribuíram para aumentar as áreas de pisoteio e prejudicar a manutenção dos canteiros.
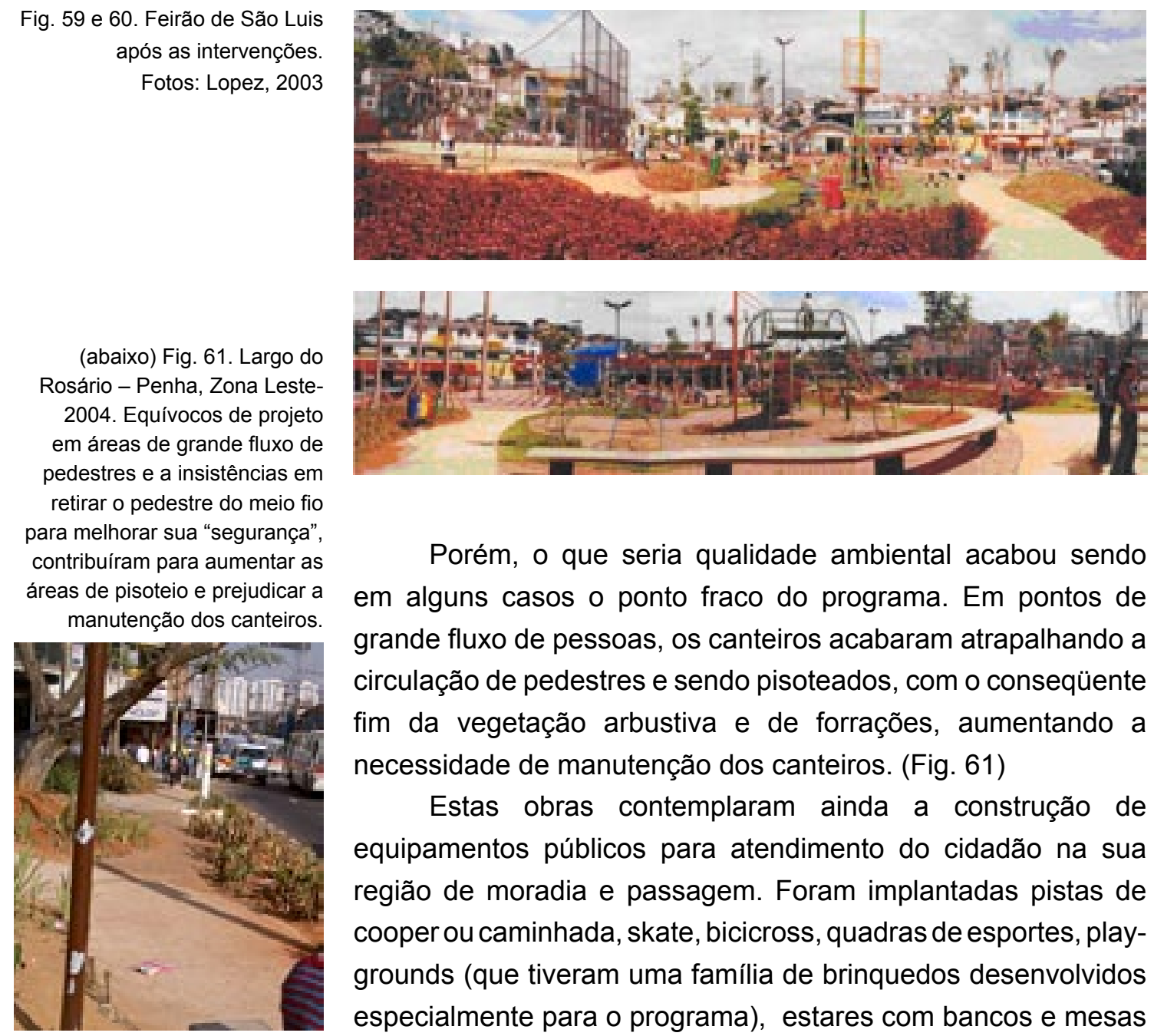

Porém, o que seria qualidade ambiental acabou sendo em alguns casos o ponto fraco do programa. Em pontos de grande fluxo de pessoas, os canteiros acabaram atrapalhando a circulação de pedestres e sendo pisoteados, com o conseqüente fim da vegetação arbustiva e de forrações, aumentando a necessidade de manutenção dos canteiros. (Fig. 61)

Estas obras contemplaram ainda a construção de equipamentos públicos para atendimento do cidadão na sua região de moradia e passagem. Foram implantadas pistas de cooper ou caminhada, skate, bicicross, quadras de esportes, playgrounds (que tiveram uma família de brinquedos desenvolvidos especialmente para o programa), estares com bancos e mesas 
de jogos criando áreas de descanso e encontros, além de palcos para eventos culturais (de pequeno porte, na escala do bairro, para estimular, principalmente crianças e adolescentes) mirantes, relógios de sol, entre outros.
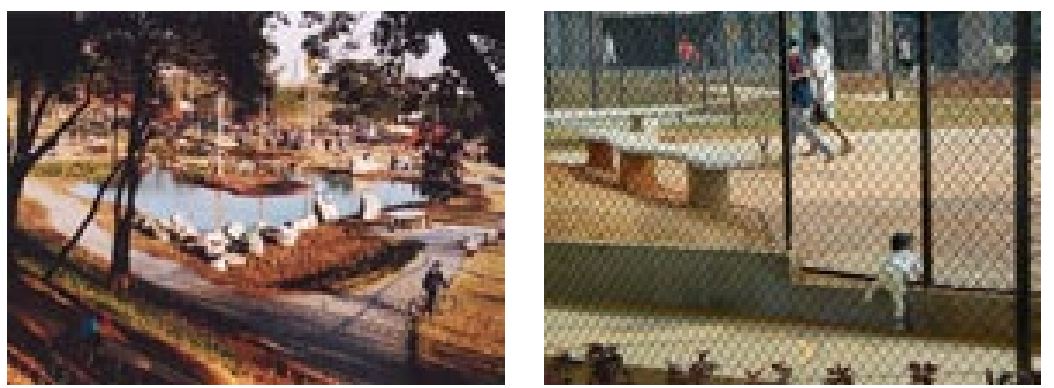

Fig. 63 e 64. Praça Gal Milton

Tavares de Souza - Lago formado pelas nascentes existentes;

Praça da Rua Antonio de Castro Lopes. Quadra de Bocha

- reivindicação dos idosos. Fotos: Lopez
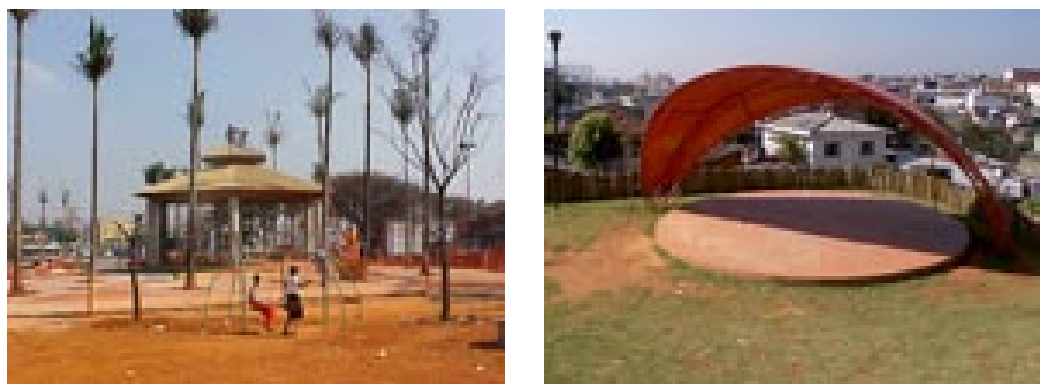

Fig. 65 e 66. Largo de São Mateus. Reforma do Coreto existente - reivindicação dos moradores;

Praça Santo Dias da Silva Palco.

Fotos: Lopez
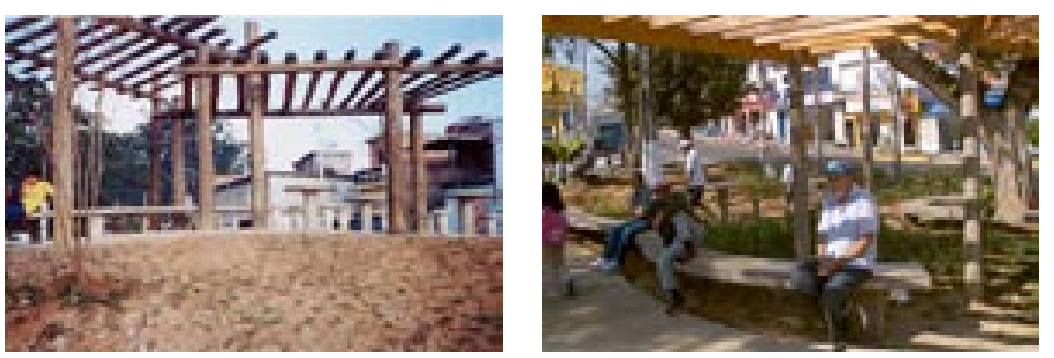

Fig. 67 e 68. Praça do Trabalhador. Pergolado com Toras de Eucalipto tratado; Largo do Japonês. Pergolado com madeira aparelhada. Fotos: Lopez
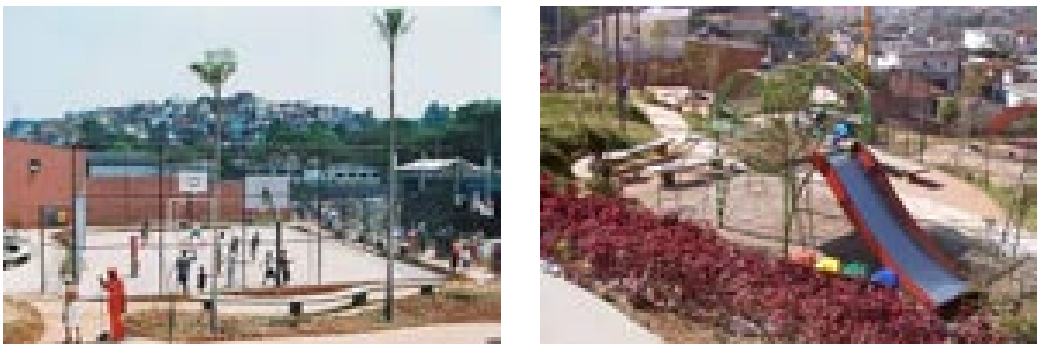

Fig. 69 e 70. Largo do Araribá Quadras Poliesportivas. Foto: Lopez , 2002; Praça Santo Dias da Silva. Sapo - Famíla de Brinquedos.

Foto: Lopez , 2003 
Fig. 71 e 72. Parceria com a CET - Companhia de Engenharia de Tráfego possibilitou a revisão e um novo projeto da sinalização vertical e horizontal do entorno das praças. Em alguns casos como na Av. Armando de Arruda

Pereira - foto lado esquerdo

- o número de vias foi revisto e ampliado e bolsões para a s paradas de ônibus foram criados. Em pontos de conflito entre automóveis e pedestres como na Praça Pe. Damião,

à direita, a sinalização foi reforçada para favorecer o transeunte. Fotos: Lopez, 2003

Ainda em algumas áreas foram construídos ou reformados centros culturais, bibliotecas, brinquedotecas, telecentros, postos de polícia comunitária e centros de capacitação ao trabalhador com pequenos auditórios. Procurou-se dotar estes espaços de iluminação adequada para seu pleno uso noturno além, de nova sinalização viária vertical e horizontal e da recuperação de todo leito carroçável do entorno imediato das praças.

Assim, a parceria com a CET foi fundamental para a questão da segurança do pedestre, que junto com a equipe coordenadora do programa procurou privilegiá-lo e afastá-lo sempre que possível do meio-fio e conduzi-lo para travessias somente nas faixas apropriadas. Uma das propostas era separálo do leito carroçável por meio da implantação de jardins, o que se mostrou não ser uma boa solução, pois os pedestres formavam trilhas entre a vegetação para a travessia em locais mais fáceis e práticos para eles e, em alguns casos a vegetação acabava dificultando a visualização do tráfego de veículos.
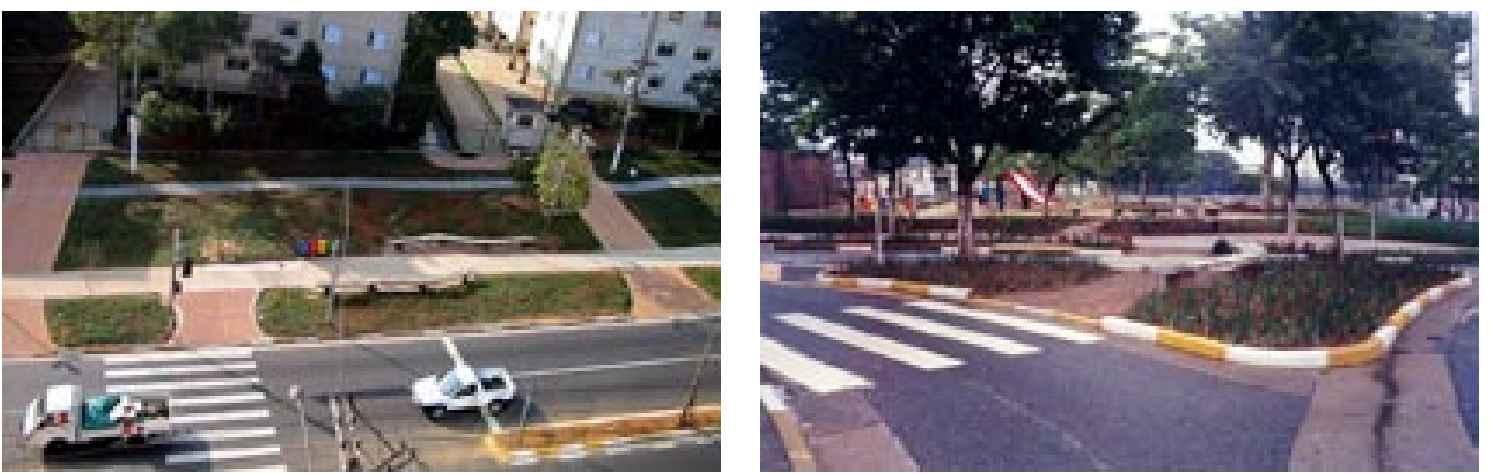

Além da CET, estabeleceram-se parcerias com várias Secretarias Municipais, bem como com as Subprefeituras e, ao mesmo tempo, ouviram-se setores organizados da população para que através de um método participativo, se formulassem os projetos.

A participação dependeu do grau de organização das associações dos bairros, mudando de bairro para bairro e de 
região para região. Para esse contato era fundamental o acesso da comunidade ao Subprefeito e a articulação deste aos setores da comunidade.

Nem sempre isso foi possível. Na verdade houve duas Subprefeituras que apresentaram maior interesse na implantação das intervenções: a Capela do Socorro (hoje desmembrada em Capela do Socorro e Parelheiros) e a Penha. Nestes casos conseguiu-se um envolvimento maior da comunidade na elaboração dos projetos e na implantação das obras, o que valorizou a apropriação dos usuários e facilitou, em alguns casos, a manutenção. Cabe ressaltar aqui, que estas foram as duas únicas subprefeituras que de alguma forma deram continuidade ao programa depois de finalizado pela gestão municipal, com a contratação de alguns profissionais participantes da equipe inicial do Programa Centros de Bairro, para a formação de um "sub-programa", agora dentro das sub-prefeituras em questão, para a elaboração e execução de projetos de praças para a sua determinada região.

Como já foi dito, os projetos foram idealizados com uma linguagem simples e pouco sofisticada, com a utilização de materiais alternativos e econômicos. O objetivo era permitir uma fácil leitura e apreensão do espaço pela população que, a partir disso, e em parceria com as sub-prefeituras, seria capaz de repeti-la, e com o apoio de cooperativas e sistemas de mutirão, implantá-la em outras áreas. Desse modo, a pretensão era que as áreas que foram implantadas funcionassem como pequenas células que seriam repetidas e que no futuro poderíamos ter um sistema de áreas verdes na periferia que se interligasse com áreas historicamente já consolidadas. Para isso foi importante conseguir distribuir as intervenções de forma mais ou menos homogênea pelas periferias das diferentes áreas da cidade. 
Optou-se por não desenvolver os projetos executivos, mas detalhes genéricos para guiar a execução. As obras foram acompanhadas por um dos projetistas responsáveis que resolveu, in loco, alguns ajustes do anteprojeto.

Nas licitações, a maior inovação foi a inclusão dos projetos de plantio. A prefeitura não possuía modelos de planilhas de referências com preços que permitissem a contratação desses serviços. Foram criados todos os novos itens necessários para a execução do plantio, como anexos às planilhas de SIURB (Secretaria de Infra-Estrutura Urbana e Obras) e SSO (Secretaria de Serviços e Obras) ou novas planilhas geradas pela própria EMURB (Empresa Municipal de Urbanização).

Desejava-se, para uma maior qualidade da execução do paisagismo, que empreiteiras de jardins executassem as obras. Isso não foi possível pois, por exigências burocráticas e para facilitar o andamento das licitações, dividiu-se as áreas em 5 lotes, que individualmente dependeriam apenas de uma construtora. As empreiteiras de jardins não tinham capacidade financeira para bancar as exigências da lei para obras dessas dimensões e somente grandes construtoras conseguiram entrar nas concorrências das licitações. Três dos cinco lotes ficaram a cargo de uma mesma empresa que venceu as concorrências.

As obras foram acompanhadas diariamente por um dos projetistas (arquitetos ou agrônomos), que ficou responsável por mais ou menos 7 áreas, e um residente, que poderiam ser arquitetos ou não, e que ficavam diariamente em uma única área. (Fig. 73 e 74)

A presença dos projetistas nas obras se revelou uma solução fácil e ágil, uma vez que não havia bases cadastrais, levantamentos topográficos nem levantamentos dos fluxos e usos existentes nos locais. Tendo suprimido estas etapas, ter os profissionais nas obras não significou uma elevação do custo. $A$ 

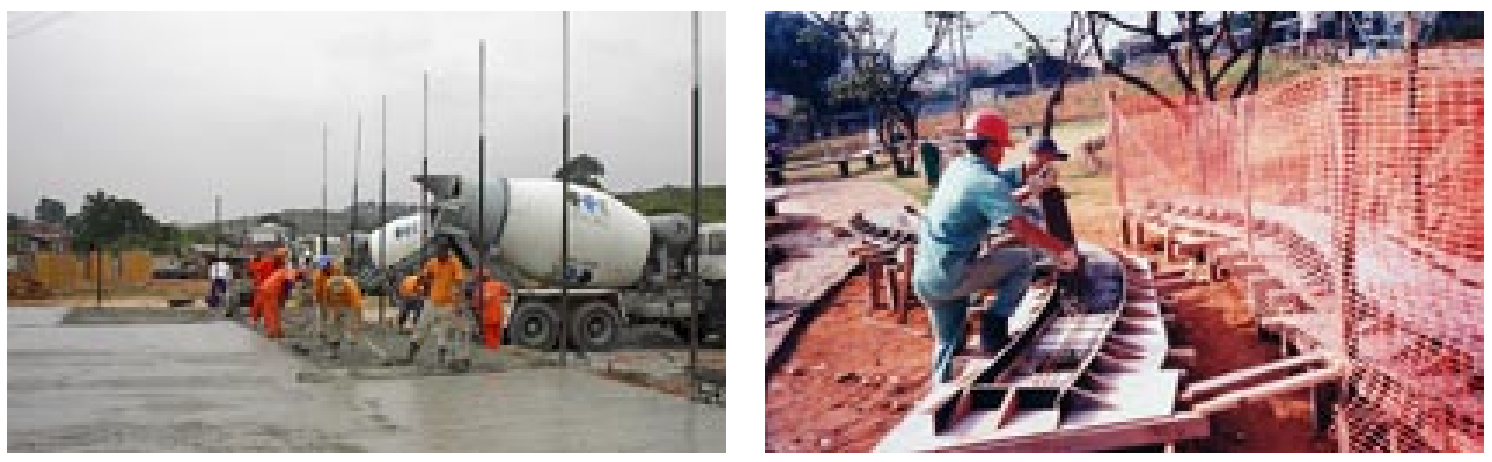

equipe que conduziu as obras se reportava aos coordenadores em caso de dúvidas e fazia as alterações e ajustes que considerava necessários marcando sutis diferenças entre as áreas.

Alguns profissionais se mostraram mais sensíveis e saíram-se um pouco melhor para resolver algumas questões como os fluxos existentes, o dimensionamento dos caminhos e os detalhes construtivos, além de outras providências que não estavam previstas no programa mas que significaram ganhos para a área. Isso também variou de acordo com cada profissional: arquiteto ou agrônomo.

\section{A a propria çã o}

Pode-se verificar a impressionante demanda que a cidade propicia para equipamentos de lazer e esportes, que são utilizados dia e noite pela população freqüentadora destes espaços, produzindo vida organizada, diálogo e convívio social.

Também é importante salientar que pesquisas não oficiais de algumas associações de bairro e da própria COHAB mostram que tais projetos auxiliaram no combate à violência urbana. Como por exemplo os Centros de Bairros, localizados em Parada de Taipas (Pirituba) e o Conj. Habitacional Faria Lima (Grajaú), com histórico de violência, tiveram forte percepção, por parte dessas
Fig. 73 e 74. Fotos do andamento das obras. $\grave{A}$ esquerda concretagem de uma das quadras poliesportivas implantadas na City Jaraguá. À direita, montagem padrão dos bancos moldados in loco na Praça Wilson Moreira da Costa. Fotos: Lopez, 2002 
Fig. 75 e 76 (abaixo). Largo do Campo Limpo. Área do Playground; Praça Bassano Del Grapa. Área de estar e convívio, ainda em implantação. Fotos: Lopez, 2003 associações, de diminuição de casos de violência a partir da apropriação das áreas pela população.

Estes fatos se dão pelo uso intensivo dos equipamentos, tais como os já citados, mas também pela instalação de iluminação apropriada, com postes baixos, sob as copas das árvores, garantindo a visibilidade e transparência que o desenho dos passeios e o projeto paisagístico procuraram.
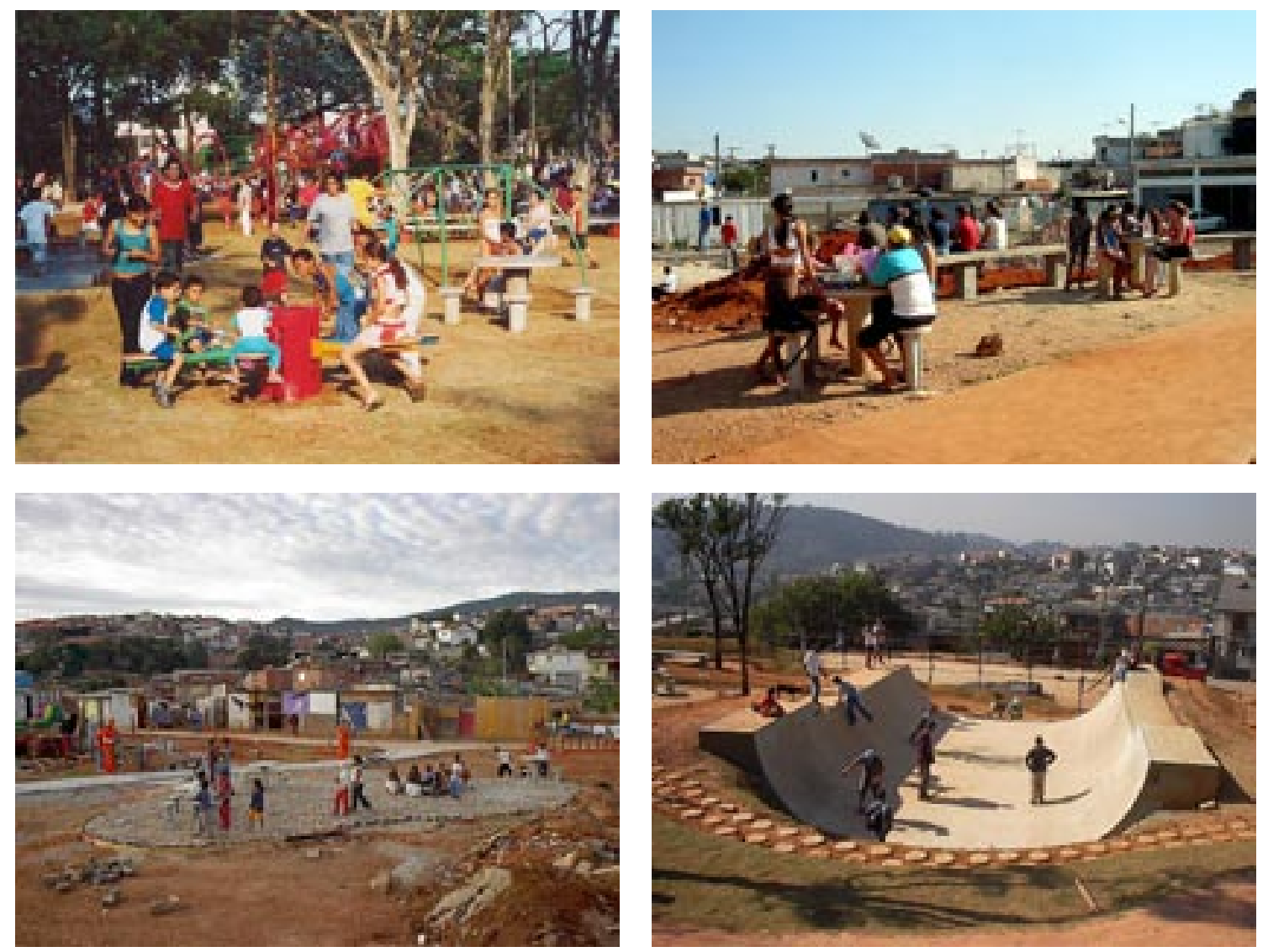

Fig. 77 e 78. Praça City Jaraguá. Área de estar com mesas - em obras; Praça EMEF Remo. Pista de

Skate. Fotos: Lopez, 2003
Se de fato foram requalificações ou apenas embelezamento dos espaços urbanos, há controvérsias. Iremos nos aprofundar mais adiante em algumas dessas áreas para entender melhor essa realidade. Mas, não podemos deixar de lado que estas ações foram instrumento formal para requalificações sociais, culturais e porque não ambientais, tornando-se necessárias 
dada a escassez latente de espaços públicos qualificados, principalmente nessas regiões.

Estes novos projetos puderam recategorizar, requalificar ou ainda articular estes espaços a outros, ou criaram símbolos e inovações que mudaram o olhar dos cidadãos sobre sua própria cidade, sobre sua identidade.

O Conjunto Habitacional Brigadeiro Faria Lima, mais conhecido como Bororé, e a Praça do Trabalhador talvez estejam entre as áreas de maior sucesso.

O Bororé, um conjunto habitacional do Grajaú, zona sul da cidade, apresentava 14 pequenas áreas públicas espalhadas, sendo que parte delas havia sido invadida pela população moradora dos edifícios e transformada em área de estacionamento privativo, enquanto o restante estava no descaso dos órgãos públicos, completamente abandonado, parecendo, algumas vezes, próprios "botas-fora" - o que tornou-se muito comum nos espaços públicos periféricos da cidade. (Fig. 79, 80 e 81)

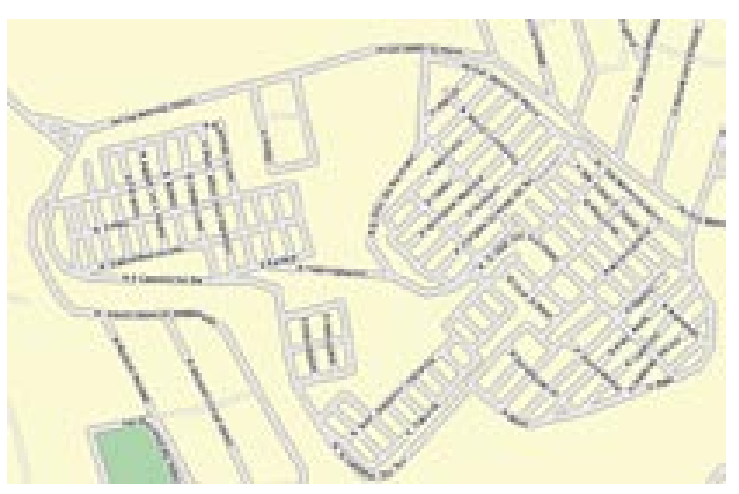

A intervenção implantou nestes espaços áreas de estar, play-grounds, pista de skate, quadras poliesportivas e passeios, além de iluminação. O resultado foi que não só mais uma pequena parcela da população se apropriou desses espaços, mas sim toda a comunidade do conjunto, de diferentes formas, desde crianças que vão às praças para se divertirem nos brinquedos até idosos que jogam xadrez e cartas em mesas instaladas,
Fig. 79 e 80. Planta do traçado viário do e foto aérea do local. 


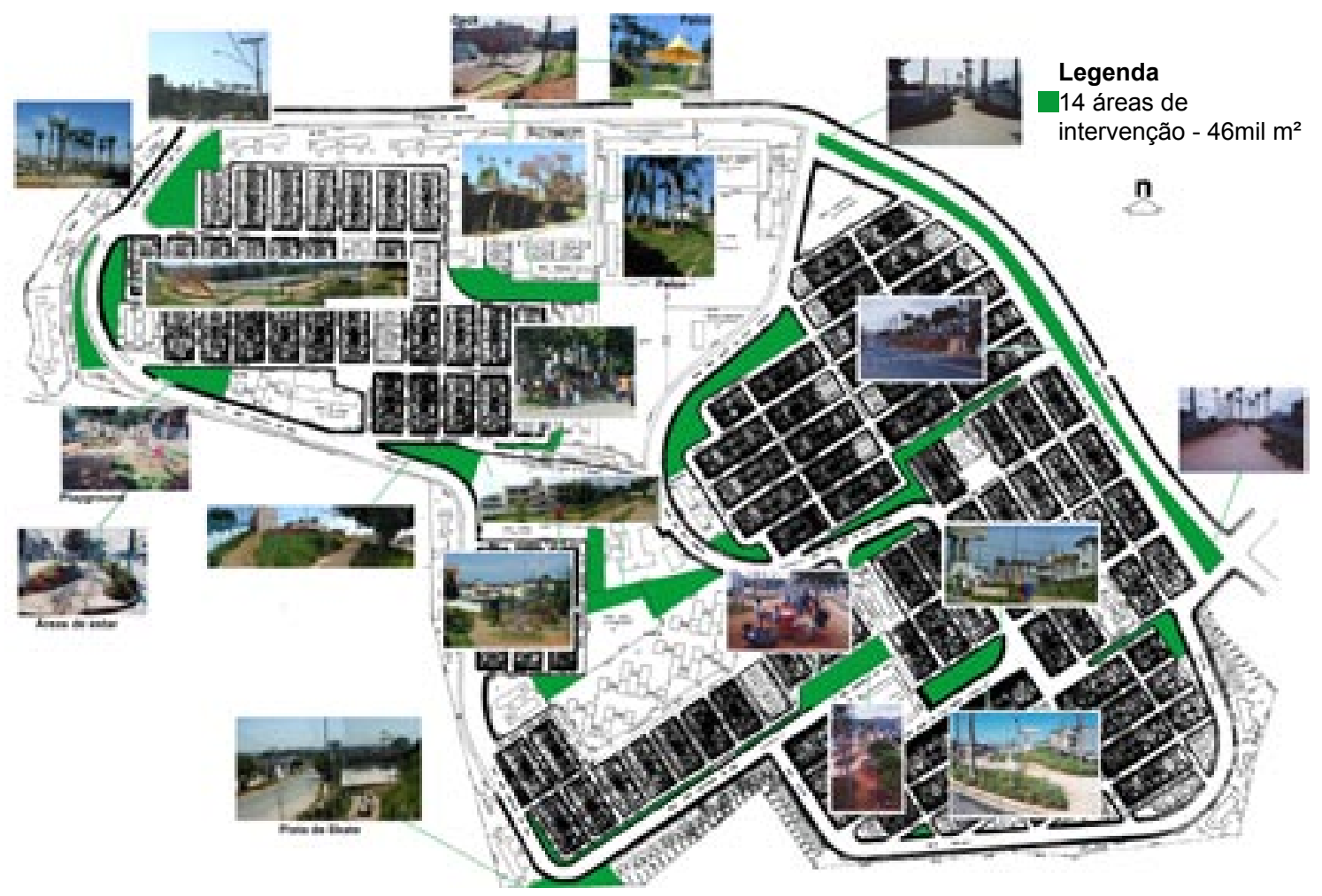

Fig. 81. Planta geral do Conjunto Habitacional com destaque nas áreas de intervenção.

Fonte: Empresa Municipal de Urbanização - EMURB

Fig. 82, 83 e 84 . Situação dos Espaços Livres Públicos no Conjunto Habitacional Brigadeiro Faria Lima antes das intervenções - abril 2002.

Foto: Empresa Municipal de Urbanização - EMURB

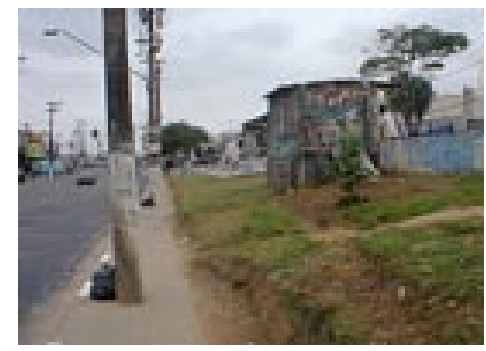

passando por organizações do bairro que promovem feiras de artesanato ou noites musicais. (Fig. 82 a 87)

Entre outros casos do conjunto, as professoras das creches e escolas de $1^{\circ}$ grau juntamente com os arquitetos responsáveis pela obra voltaram os seus portões para um antigo "beco" que transformou-se em horta. Este tipo de apropriação acaba resultando na diminuição dos casos de violência, pois provocou o afastamento do tráfico de drogas que ocupava o local e que foi
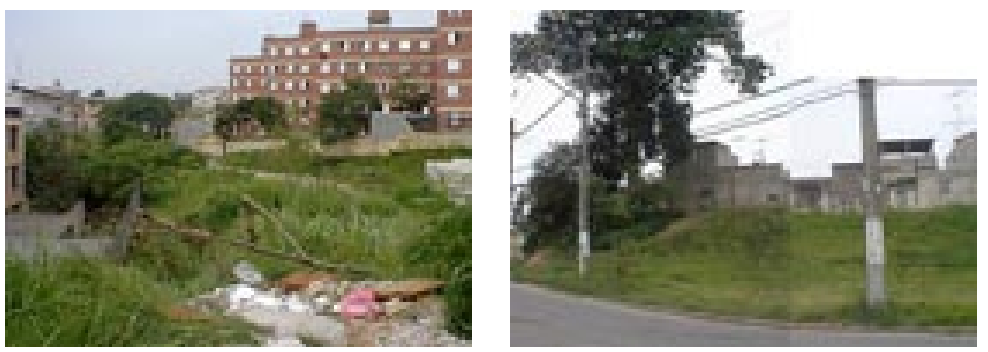

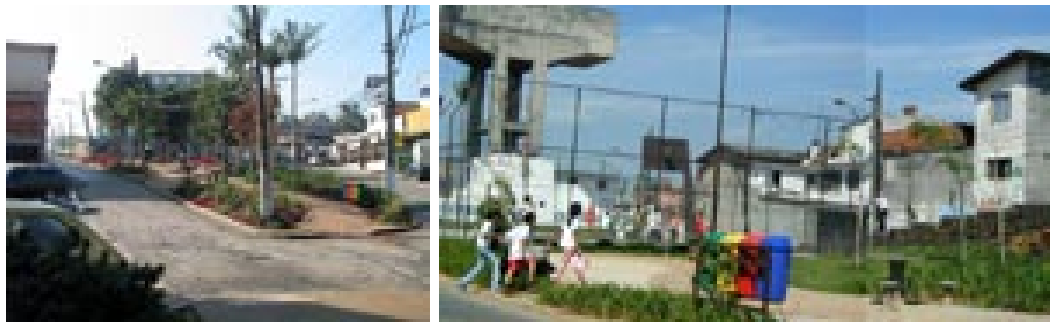

repelido pelo uso da população.

Milton Santos desenvolveu a noção da indissociabilidade de sistemas de objetos, como um produto social e de sistema de ações na Geografia afirmando que "Sistemas de objetos e sistemas de ações interagem. De um lado, o sistema de objetos condiciona a forma como se dão as ações e, de outro lado, o sistema de ações leva à criação de objetos novos ou se realiza sobre objetos preexistentes. É assim que o espaço encontra a sua dinâmica e se transforma".

Já na Praça do Trabalhador, área de aproximadamente $25.0000 \mathrm{~m}^{2}$, em Parelheiros, também na zona sul, se caracterizava como uma rotatória abandonada e teve a implantação dos mesmos tipos de equipamentos antes descritos, além de pista de Cooper, telecentro e um centro de capacitação. A SPTRANS teve que aumentar o número de carros das linhas que passam pela praça nos finais de semana, tamanho o uso.

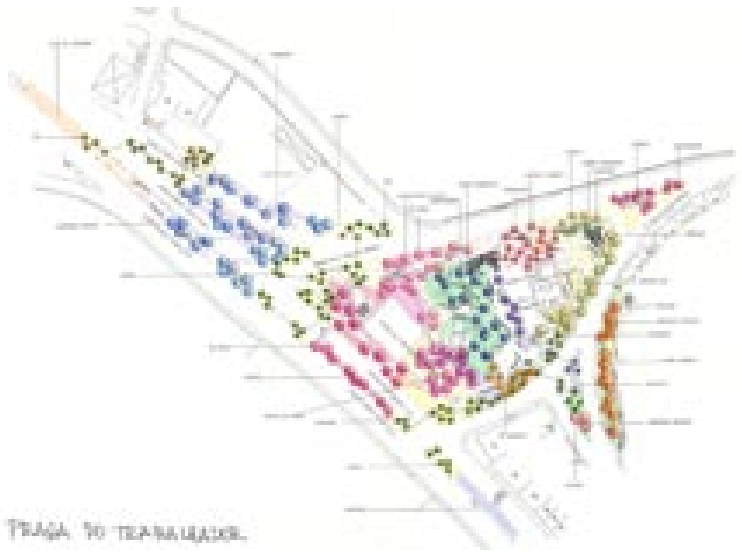

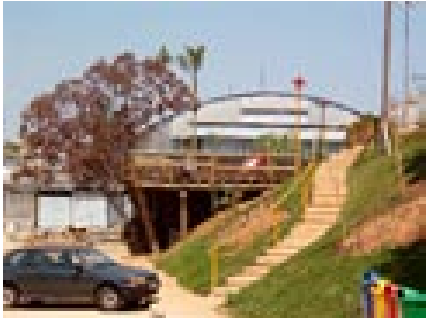

Fig. 85, 86 e 87 . Situação dos Espaços Livres Públicos no Conjunto Habitacional Brigadeiro Faria Lima após as intervenções - maio 2003. Área do deck, área 3 e quadra poliesportiva.

Fotos: Lopez, 2003.

Fig. 88. Planta Geral da Praça do Trabalhador.

Fonte: Empresa Municipal de Urbanização - EMURB 

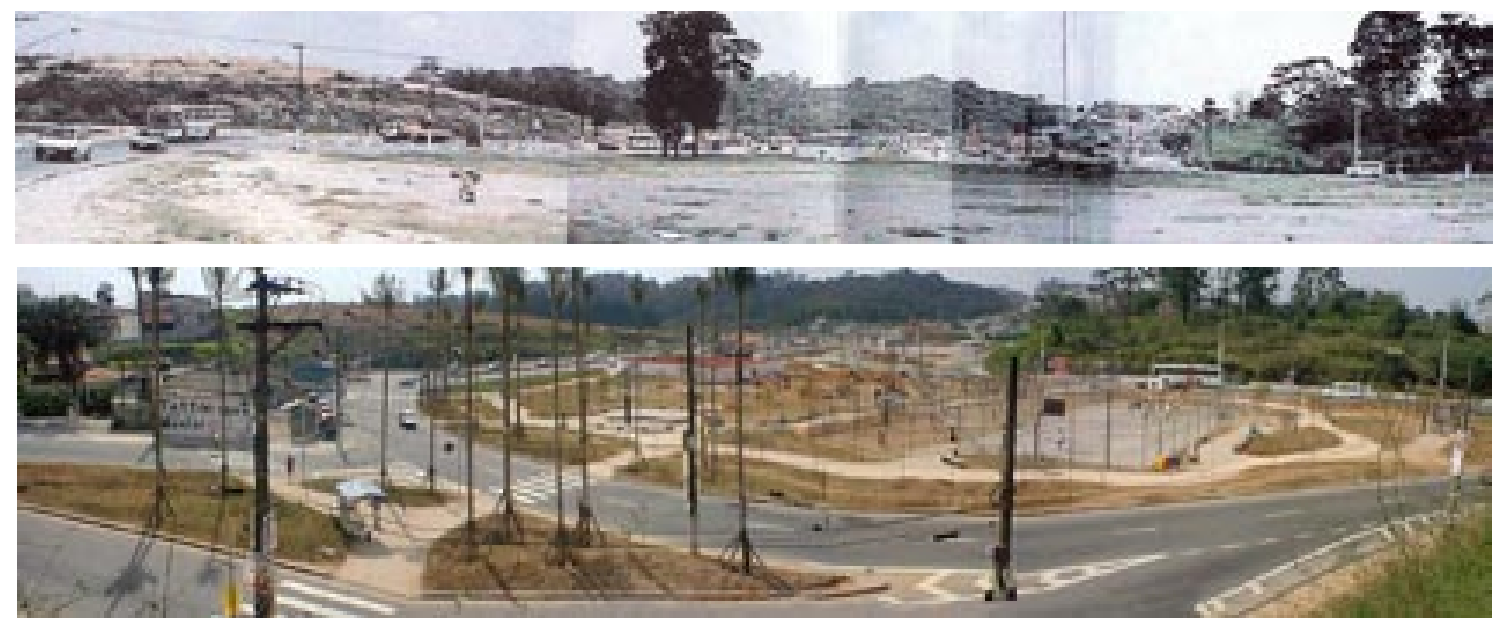

Fig. 89. Foto antes da intervenção - fevereiro de 2002.

Foto: Meirelles, 2002.

Fig. 90. Foto depois da intervenção - setembro 2002.

Foto: Meirelles, 2002.

Fig. 91. Planta Geral da intervenção.

Fonte: Empresa Municipal de Urbanização - EMURB

Por outro lado, a Praça conhecida como Entrada de São Miguel foi um verdadeiro fracasso. A área se revelou totalmente imprópria para a configuração de uma praça pois se trata de um espaço livre público sob um viaduto, no início da Av. Jacu Pêssego, zona leste da cidade. Uma área com o sistema viário "agressivo" e onde a implantação de equipamentos de convívio e lazer não foi suficiente para criar vida pública.

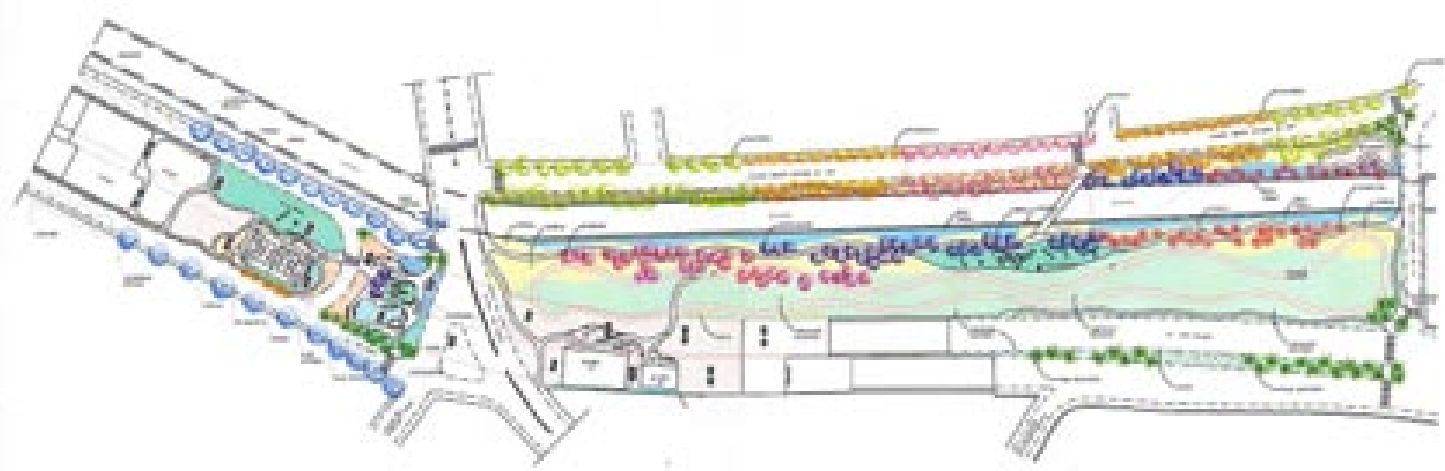

INTTADA TE STO MiGUEL 

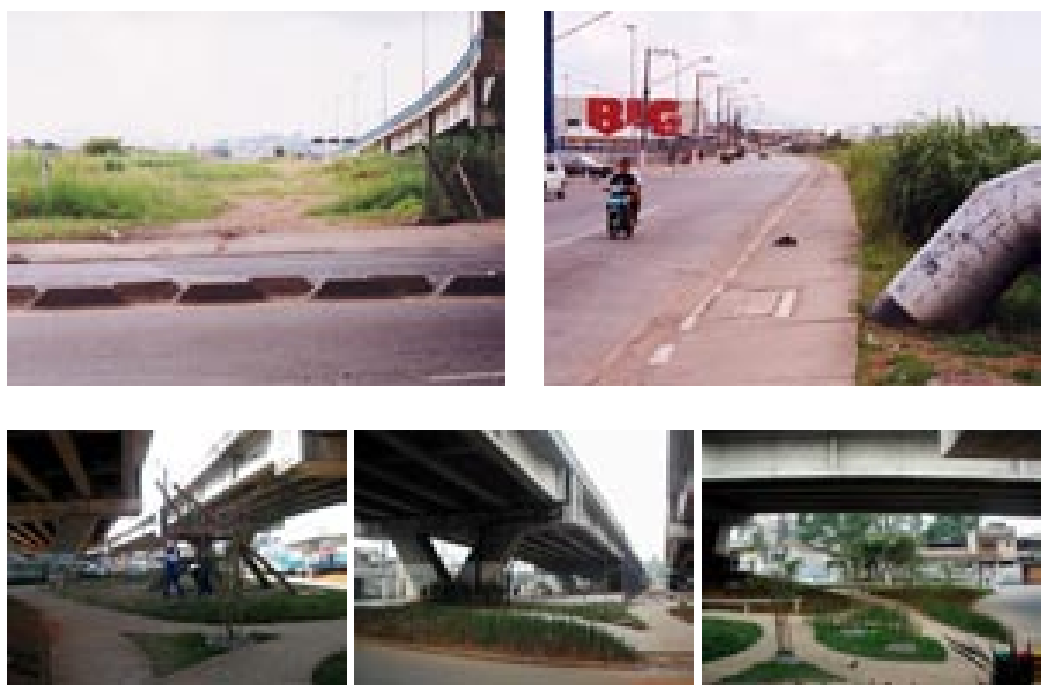

Projetos em áreas como esta confirmam a idéia que “... o lugar e a praça não são apenas sistemas de objetos, materialidade, mas incluem um sistema de ações, uma dimensão cultural e política". (QUEIROGA, 2001)

De nada adianta implantarmos espaços com equipamentos de convívio, lazer e contemplação ou com desenhos mais sofisticados do que foi o Programa Centros de Bairro, se nas áreas propostas não houver uma potencialidade para a constituição do uso pretendido.

Fica claro que há necessidade da leitura e a análise da paisagem e do cotidiano nos quais estão inseridas essas áreas de intervenção, para a elaboração de uma proposta capaz de instituir ou reforçar os lugares para a vida pública.

O Programa Centros de Bairro pode realizar isso em algumas áreas, em outras teve que satisfazer apenas as imposições políticas de Subprefeitos. Talvez grande parte dos erros não tivesse acontecido se isso tivesse sido realmente levado em consideração. Ainda assim ocorreram algumas requalificações culturais e ambientais - no sentido mais amplo da palavra - funcionando como um sistema de melhorias urbanas na periferia da cidade de São Paulo, capaz de recategorizar estas
Fig. 92 e 93. Fotos antes da intervenção.

Foto: EMUB, 2001

Fig. 94, 95 e 95a. Fotos depois da intervenção.

Foto: EMUB, 2004 
áreas e mudar o olhar do cidadão sobre a sua cidade a partir de sua vivência nos lugares públicos qualificados pelo programa.

Transportar esta noção para projetos em espaços públicos, com usos intensivos e apropriações diversas, é torná-los ricos à medida que eles nos oferecem surpresas e ensinamentos para sua releitura e formação de um novo conhecimento.

\section{A m a n u t e n çã o}

$\mathrm{Na}$ maioria das praças a apropriação por um grande número de usuários evidenciou a demanda existente por essas áreas. Em alguns casos o impacto foi maior que em outros, variando entre bairros mais e menos consolidados e de acordo com a demanda local.

Todos os espaços apresentaram problemas de manutenção que se manifestaram tão logo a área foi entregue, principalmente com relação aos canteiros. Alguns problemas já surgiram durante o período de implantação das áreas; como foi o caso da dimensão da "boca" do " jacaré" ( um dos brinquedos desenvolvido especialmente para o programa) que teve que ser re-dimensionada pois, seu desenho inicial favorecia que as crianças se pendurassem na boca, o que ocasionou alguns tombos; além do pisoteio intenso dos canteiros. Quando esses problemas eram detectados durante a obra, providenciou-se alguma solução, nem sempre definitiva. (Fig. 96 e 97)

Durante os quatro meses iniciais a manutenção ficou sob responsabilidade das construtoras. Após 120 dias do término da execução ficou então a cargo das subprefeituras, que não possuem estrutura para isso. Na sub-prefeitura da Penha, por exemplo (na qual tive a oportunidade de trabalhar com espaços públicos, logo após a finalização do Programa Centos de Bairro), existia apenas uma equipe de aproximadamente 8 homens 


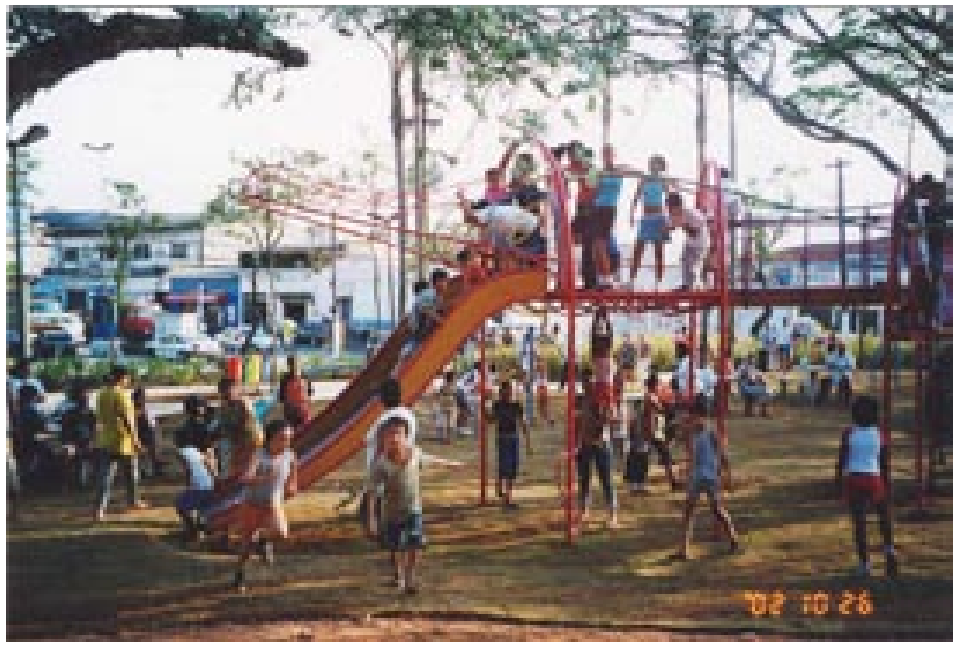

responsável pela manutenção das áreas livres. A prefeitura não tinha nenhum tipo de contrato de limpeza/varrição das praças. Toda a sujeira, incluindo os sacos plásticos e papéis acumulados pelo uso intenso, principalmente nos finais de semana, não poderiam ser retirados. Como agravante, muitas vezes o gari que estava varrendo as sarjetas, para facilitar, jogava o lixo nos canteiros da praça.

A presença dos equipamentos fora do padrão da prefeitura e a implantação de áreas ajardinadas com arbustos e forrações contribuíram para aumentar a necessidade da manutenção e a limpeza dos espaços, e assim as áreas foram se degradando.

A EMURB na época se empenhou para formar grupos dentro das sub-prefeituras para fazer algumas adequações dos projetos e parcerias com as empresas que prestam serviço de limpeza para a prefeitura, mas não obteve resultados.

Hoje temos algumas áreas praticamente perdidas. Principalmente aquelas que não foram sequer terminadas como foi o caso da City Jaraguá e da Entrada da Vila Maria.

Em outras áreas como a Vila Brasilândia, o vandalismo prevaleceu. Os brinquedos de ferro foram aos poucos sendo recortados para a revenda do material e o pisoteio foi intenso devido à proximidade das escolas e do TeleCentro.

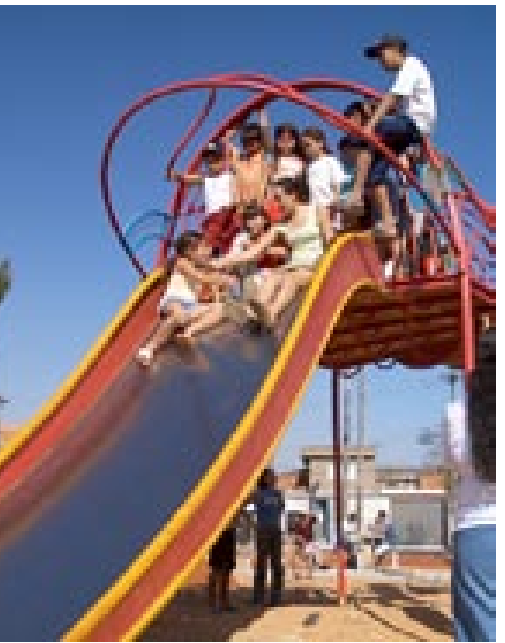

Fig. 96 e 97. À esquerda Brinquedo - circuito Jacaré original implantado no Lgo. Campo Limpo. Após os problemas com quedas, de crianças que "trepavam" na cabeça do brinquedo,local não previsto em projeto para o acesso infantil, houve a revisão do projeto com a conseqüente diminuição da cabeça, o que tornou o acesso a essa região mais difícil - foto à direita, Pça Bassano Del Grappa.

Foto: Lopez, 2003 

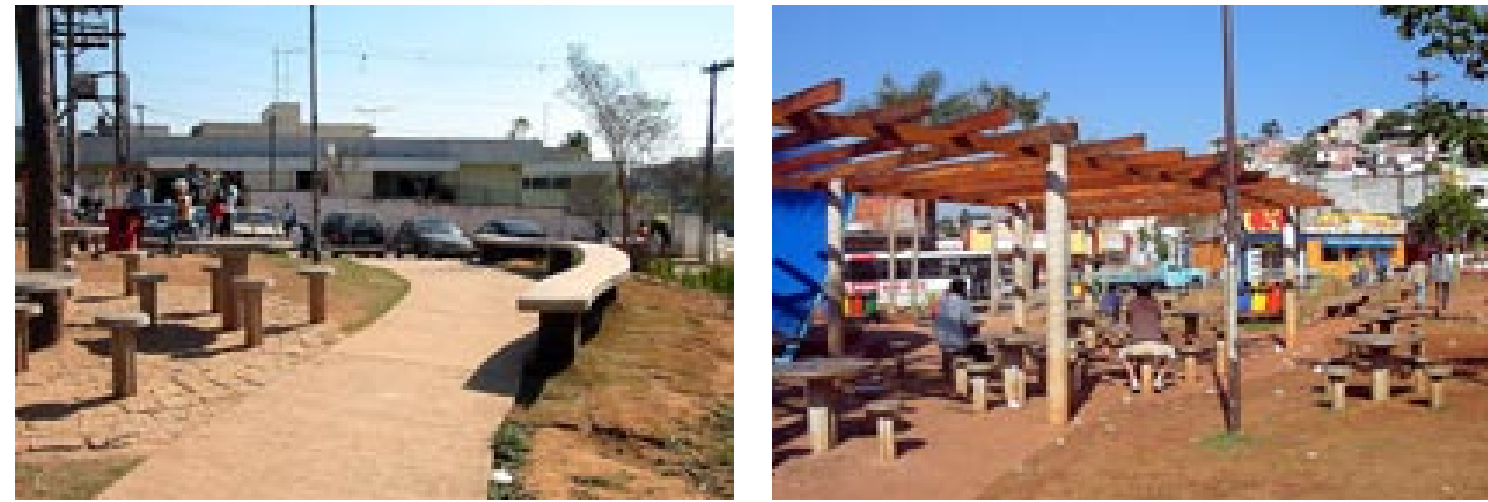

Fig. 98 e 99. Fotos dos pisoteios pelo grande uso das áreas.

Em algumas nem a grama sobreviveu. Não há manutenção e nem o lixo é retirado pela prefeitura, não existe uma licitação para isso, somente para a varrição das sarjetas. A esquerda uma segunda feira no Feirão do São Luis. À direita o pisoteio nas praças da Cidade

Tiradentes - junho 2003. Foto: Lopez, 2003.

Fig. 99A a 99F. (nesta página e na seguinte) Fotos atuais de algumas praças do programa - julho 2007. Fica evidente o descaso do poder público com a manutenção dos espaços livres. O uso mesmo sendo em menor intensidade, continua existindo, porém, em equipamentos deteriorados $\mathrm{e}$ mal mantidos, prejudicando a segurança de seus usuários.
Os brinquedos que restaram encontram-se com um grau elevado e corrosão. Os balanços de tanto uso foram gastos e as correntes arrebentadas.

Hoje, algumas praças encontram-se com o mesmo grau de abandono que estavam as áreas livres antes das intervenções. O descaso continua e o problema da manutenção ainda não foi solucionado. Fica claro que junto com o programa de implantação de espaços livres deve existir, ou melhor, um não se viabiliza sem o outro, um programa de gestão e manutenção desses espaços.
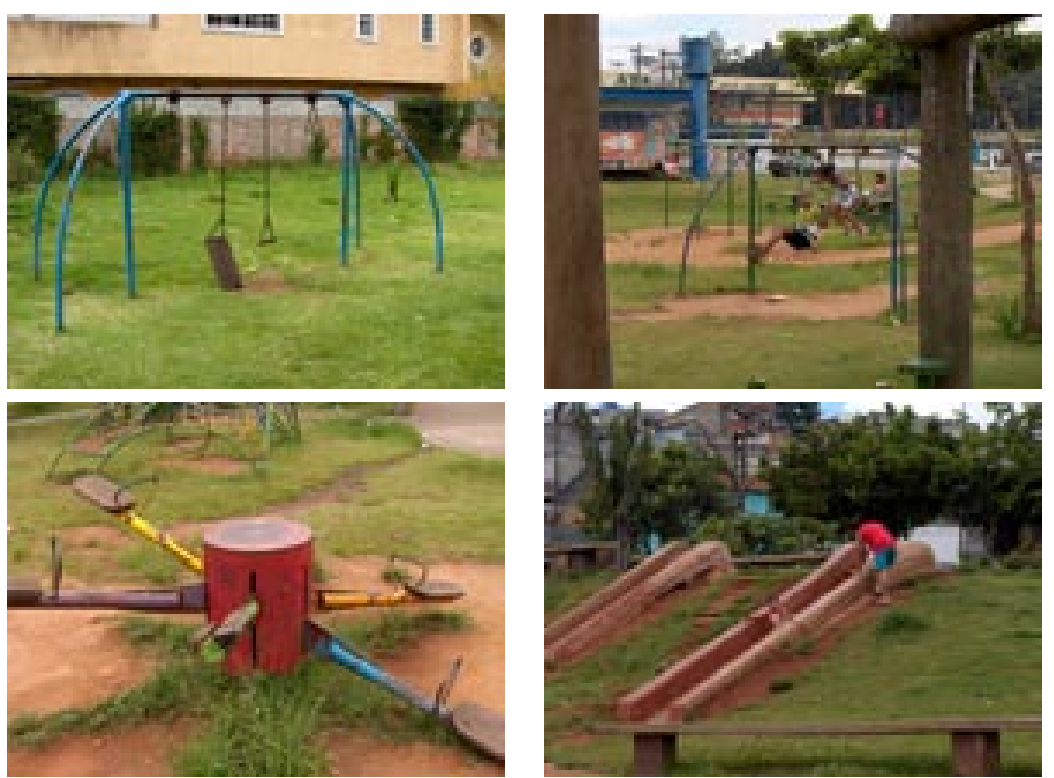
4. O Programa Centros de Bairro

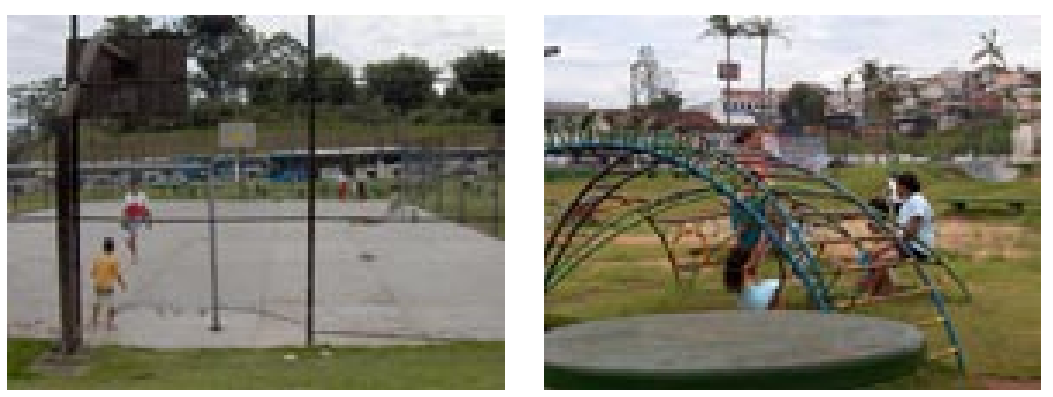


4. O Programa Centros de Bairro 


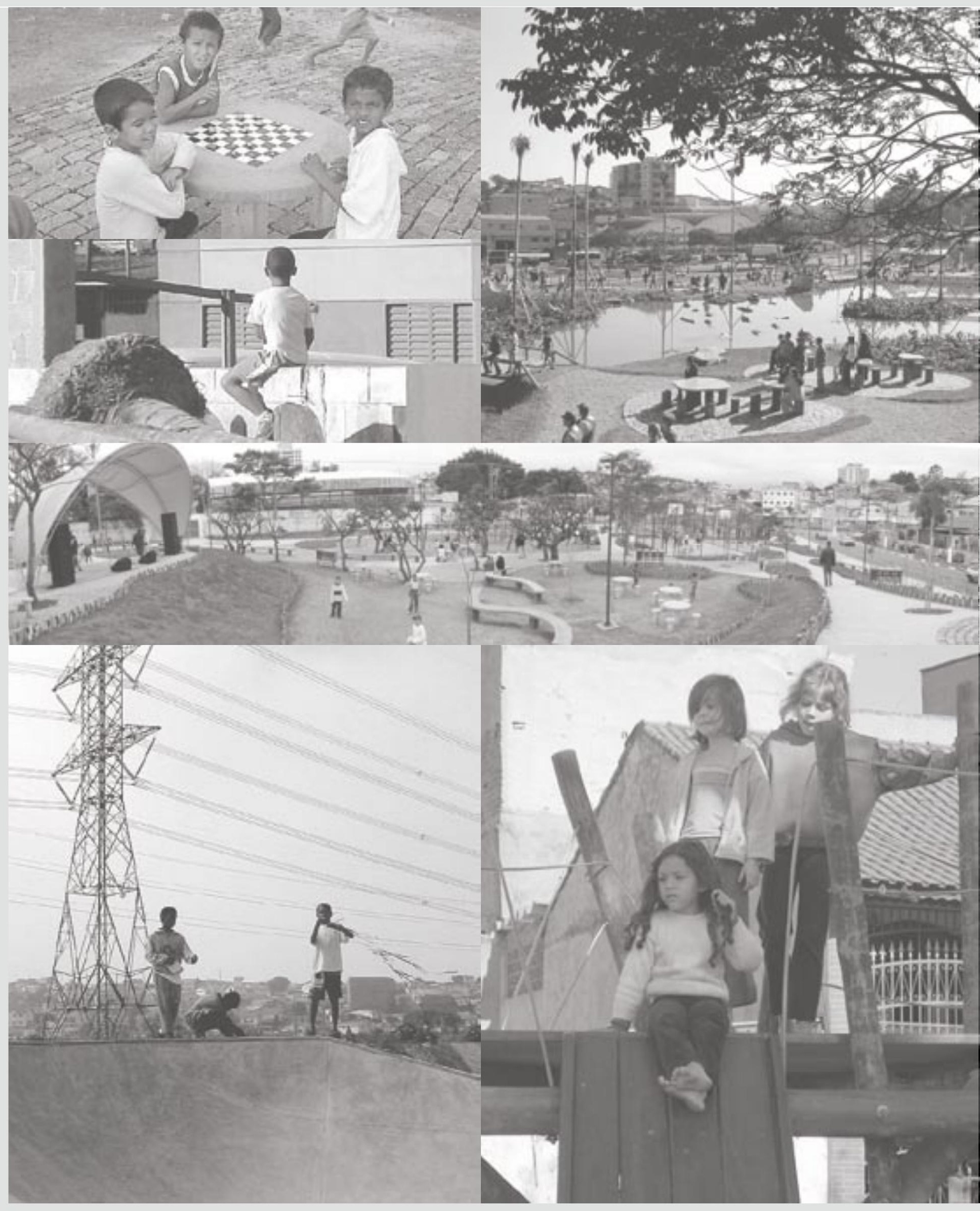




\section{C a pít u lo 05 \\ A CONTRIBUIÇÃO DO PROGRAMA CENTROS DE BAIRRO NO SISTEMA DE ESPAÇOS LIVRES DA REGIÃO DA CAPELA DO SOCORRO}

Com base nos capítulos anteriores, este capítulo adentra na configuração do Sistema de Espaços Livres Públicos da região da Capela do Socorro e de sua relação com as áreas de intervenção do Programa Centros de Bairro nessa região.

Faz-se aqui uma análise da relação destas praças com áreas públicas já consolidadas, e da efetiva contribuição do Programa Centros de Bairro para a conformação de um Sistema de Espaços Livres Públicos mais estruturado para a cidade de São Paulo.

Por fim, são analisadas as 4 praças que o Programa implantou na região da Capela do Socorro: o conjunto habitacional brigadeiro faria lima - o bororé, av. ipanema $x$ av. dos lagos, a várzea do córrego são josé e a praça do trabalhador; suas relações com os usuários destes espaços, com o bairro, com o distrito e com a cidade; procurando identificar as transformações sociais e porque não ambientais que essas intervenções causaram a estes. 
5. A Contribuição do Programa Centros de Bairro no Sistema de Espaços Livres da Região da Capela do Socorro 


\section{A r e g i ão d a C a p e I a d o So corro}

A região conhecida como Capela do Socorro, na gestão municipal de Marta Suplicy (2001-2004) foi subdividida em duas Sub-prefeituras: Capela do Socorro e Parelheiros, no entanto, apresentam a mesma origem e características em sua formação.

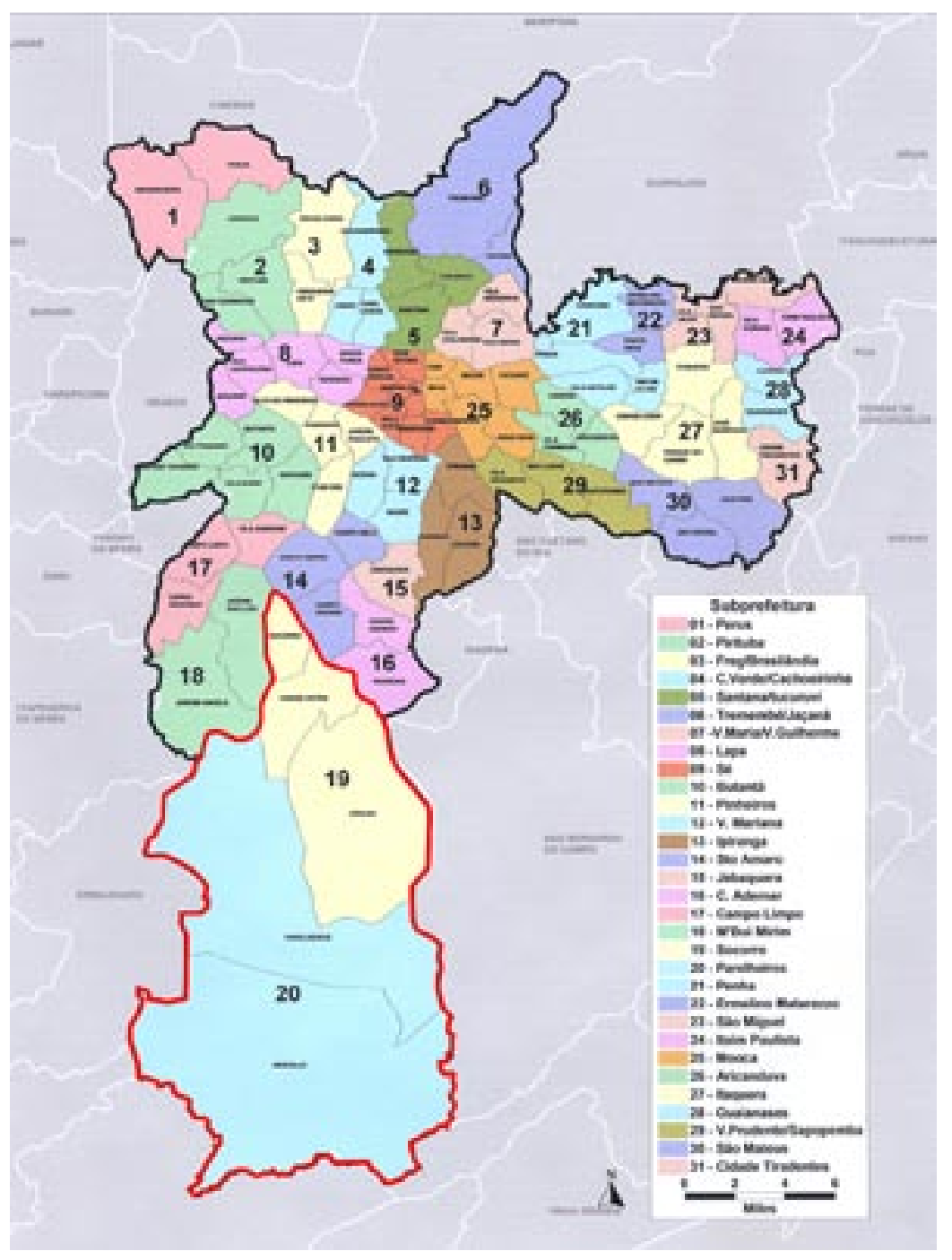



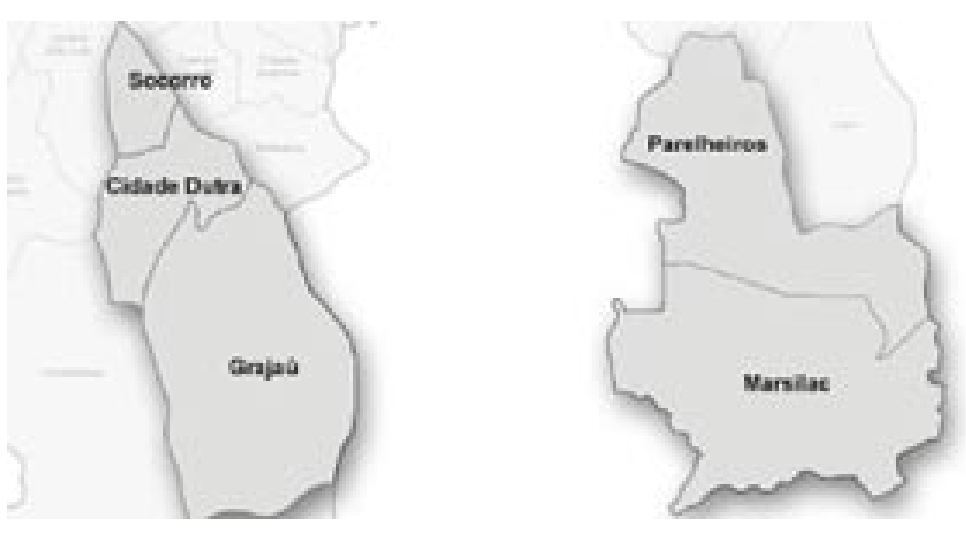

Localizada numa vasta área abaixo dos canais dos rios Jurubatuba e Guarapiranga, limita-se ao norte com as Subprefeituras de Santo Amaro e Campo Limpo; a leste com o Município de São Bernardo do Campo; a oeste com Itapecirica da Serra, Embu-Guaçu e Juquitiba; e, ao sul, com Itanhaém e São Vicente, na região da Serra do Mar. Era formada pelos distritos de Socorro, Cidade Dutra, Grajaú, Parelheiros e Marsilac que, juntos, compõem o extremo sul do município de São Paulo, com uma superfície de $487,8 \mathrm{~km}^{2}$, que corresponde a $1 / 3$ do território do município, incluindo parte das represas de Guarapiranga e Billings, além de $67 \%$ da área rural do município.

A ocupação da Capela do Socorro está estreitamente relacionada à expansão e estruturação urbanas da Subprefeitura de Santo Amaro, à qual esteve administrativamente ligada até 1985.

Sobre épocas anteriores, existem informações de que esta região era habitada pelos índios tupis, que ocupavam também vários pontos da região sul do Brasil, além do litoral. Já no século $X X$, os guaranis, sub-grupo tupi, no curso de seu processo migratório, chegaram a Parelheiros e lá se fixaram. Ainda remanescentes desse núcleo são as duas aldeias existentes na região - a de Curucutu e a do Morro da Saudade - e que reúnem cerca de 600 indígenas.

O interesse pela região da Capela do Socorro desponta
Fig. 101. Planta das Subprefeituras da Capela do Socorro, à esquerda, e de Parelheiros à direita; com indicação de seus respectivos distritos.

Fonte: Prefeitura do Município de São Paulo, PMSP. 
nas primeiras décadas do século $X X$, após a construção das barragens da Light: em 1907, a do rio Guarapiranga, dando origem à represa que ocupa área de $33,9 \mathrm{~km}^{2}$, com a finalidade principal de regularizar a vazão do rio Tietê e garantir a geração de energia na Usina Edgard de Souza em Santana do Parnaíba; e, a do rio Grande, construída após a grande seca de 1924, que deu origem à represa Billings, que ocupa uma área de $130 \mathrm{~km}^{2}$ entre São Paulo e São Bernardo do Campo.

As represas criaram um potencial de lazer até então desconhecido na região, criando intensa especulação imobiliária em torno de loteamentos para construção de equipamentos recreativos. Chácaras de recreio, clubes de campo, clubes náuticos e balneários caracterizam extensas áreas dos arredores das represas.

A construção da auto-estrada Washington Luís em 1928, com $16 \mathrm{~km}$, ligou o Ibirapuera a Interlagos, via Santo Amaro e Socorro e foi, posteriormente, completada com a Avenida Interlagos, impulsionando ainda mais o desenvolvimento das atividades recreativas da região.

O objetivo era assentar, de frente para a Represa de Guarapiranga, um bairro residencial de alto padrão para atender a camadas de maior poder aquisitivo. No entanto o empreendimento não evoluiu; anos depois, apenas algumas famílias haviam se instalado, em meio a quarteirões completamente vazios. Posteriormente, muitas das casas construídas para fins residenciais acabaram sendo ocupadas por restaurantes.

Até a década de 40, a Capela do Socorro era ainda muito pouco ocupada. No entanto, esses anos marcaram o início do processo de abertura de loteamentos industriais em Santo Amaro que, pela proximidade, começam a afetar a dinâmica urbana da região. Os trabalhadores das empresas de Santo Amaro encontraram aqui, um local mais acessível para morar.

Outros bairros continuaram a se formar como resultado de iniciativas imobiliárias, através de loteamento de glebas quase 
sempre sem preocupações urbanísticas ou outros critérios de implantação, além da obtenção de lucros. Característica comum a todos foi o fato de que a linha de ônibus surgiu em decorrência do núcleo já loteado e ocupado. Por outro lado, as estradas percorridas pelos ônibus funcionavam como eixos, gerando pequenas aglomerações em torno dos pontos de parada ou no terminal da linha. Nestes locais instalaram-se estabelecimentos comerciais e de serviços, geralmente modestos, para atender às necessidades locais.

Nas décadas de 1950 e 1960 o Estado de São Paulo viveu intenso processo de expansão industrial, com importantes alterações no padrão de localização da indústria mais moderna e de maior porte. Na cidade de São Paulo, este processo teve como um de seus aspectos, a ampliação do parque industrial de Santo Amaro, que se consolida como um dos mais importantes pólos de emprego industrial da região metropolitana. A disponibilidade de áreas, as facilidades de transporte, particularmente com a construção do sistema de marginais do rio Pinheiros e a abundância de água e energia contribuíram para atrair grande número de estabelecimentos industriais dos setores mais modernos da indústria. Estes se instalaram ao longo do canal de Jurubatuba, chegando até as proximidades do Largo do Socorro.

Assim, a região passou a acomodar parte do crescimento urbano da cidade, uma vez que sua área rural era imensa e relativamente próxima do centro industrial de Jurubatuba e dos dinâmicos centros de comércio e serviços localizados ao sul e sudoeste da região metropolitana. Para Capela afluíram significativos segmentos da população trabalhadora que buscavam áreas ainda não consolidadas e com disponibilidade de terra urbana a baixo custo.

Os novos bairros que então surgiram acompanharam o padrão periférico de expansão urbana que caracterizou o crescimento de São Paulo, particularmente nos anos 70 . Os 
arruamentos penetraram em áreas onde o solo é mais vulnerável à erosão e com altas declividades, o que o torna menos adequado à urbanização.

Sem dispor de infra-estrutura urbana, de equipamentos sociais e distantes do transporte coletivo, grande número de trabalhadores autoconstruíram suas casas em lotes muitas vezes ilegais e comprados através de longos financiamentos.

A partir de 1975 a ocupação da região de Capela do Socorro passou a ser legalmente subordinada à Lei de Proteção dos Mananciais e à legislação de zoneamento industrial. Esta última obteve certo êxito no que se refere às restrições à implantação de novas indústrias na região e ao controle de expansão das existentes. No entanto, a legislação relativa aos mananciais foi insuficiente para conter o avanço da urbanização e a degradação ambiental.

O crescimento populacional é um importante indicador das transformações ocorridas na região: de 36.510 habitantes em 1960, Capela do Socorro passou a 317.179 em 1980 e, projeções baseadas no Censo de 1991 e na Contagem da População em 1.996, estimam que a região contava em 2000 com 684.677 habitantes. Isso representa um incremento populacional de mais de $768 \%$ nos primeiros 20 anos da série e novo crescimento de $115 \%$ nos últimos 20 anos.

\section{Parelheiros}

Sendo a maior subprefeitura de São Paulo, localizada no extremo sul da cidade, Parelheiros contempla os distritos de Parelheiros e Marsilac, totalizando uma área de $350 \mathrm{~km}^{2}$, cerca de $25 \%$ dos $1507 \mathrm{~km}^{2}$ de São Paulo. Ainda muito pouco povoado, tem a maior parte da área coberta por reservas ambientais de Mata Atlântica - nele se localiza a APA Capivari-Monos. Os poucos habitantes têm o poder aquisitivo mais baixo da cidade. A região é praticamente desconectada do centro da cidade, devido 
à escassez de vias e de transporte público.

É também em Parelheiros que está localizada a Cratera da Colônia com 3,5 $\mathrm{km}^{2}$. Um marco geológico produzido por meteorito há milhões de anos. Parte dela é ocupada por 25 mil pessoas em loteamentos irregulares, outra por um presídio Estadual (cerca de 1500 presos); e o restante (uns $50 \%$ ) preservada como área agrícola tradicional. A área é tombada pelo Condephaat (Res. SC 60 de 20.08.2003). No Brasil existem apenas cinco destas estruturas, e cerca de 70 no mundo todo. Porém, a cratera de Colônia é a mais próxima de um ambiente urbano (está a $35 \mathrm{~km}$ do centro da cidade).

Apesar das restrições impostas pela legislação ambiental, a região apresenta urbanização intensa e desordenada, com parte da população residindo de forma precária e sérios impactos sobre os processos naturais de produção de água, devido à impermeabilização do solo, ao desmatamento, ao despejo de esgotos e ao assoreamento dos corpos d'água. Seguindo esse processo de urbanização, a população cresce de forma irregular, com baixa renda, aumentando de forma inadequada o déficit de serviços e infra-estrutura. Atualmente o número da população é de aproximadamente 200.000 , podendo se incrementar ainda mais com a passagem do Rodoanel previsto para cortar a região.

Atualmente possui elevado índice pluviométrico e a mais baixa temperatura do município no inverno, com geadas freqüentes. É a área mais preservada com remanescentes de Mata Atlântica $(62,4 \%)$ e reflorestamento de cerca de $4 \%$ (pinus, eucaliptos). Inclui parte da Bacia Hidrográfica das represas Guarapiranga e Billings. Parelheiros se destaca em relação à Colônia Paulista pelo fato de haver uma estrada aberta no século XIX, por iniciativa de Henrique Schunck (alemão), pai do fundador de Cipó (hoje distrito de Embu-Guaçu). A estrada de Parelheiros, atual Avenida Sadamu Inoue, ligava as vilas de Embu-Guaçu e São José, de onde se podia partir para Rio Bonito 
e Santo Amaro, evitando, assim, a passagem pela Colônia, onde havia a mais antiga estrada da Conceição.

Os bairros de Jaceguava e Casa Grande - que fazem parte da Subprefeitura de Parelheiros - foram sendo ocupados por famílias japonesas, onde estas se dedicavam ao trabalho agrícola, destacando-se no setor de hortifrutigranjeiros, tornandose importantes fornecedores deste gênero ao abastecimento da cidade.

\section{O S istem a de Espaços Livres da Região d a C a pe I a do socorro}

Como já descrito em capítulos anteriores, São Paulo apresenta hoje um déficit expressivo de áreas livres públicas para lazer e convívio, em especial de praças e parques. Alguns aspectos caracterizam esse déficit :

- o município está dividido em 96 distritos mas conta apenas com 38 parques, municipais e estaduais, evidenciando a inexistência de parques em muitos bairros;

- 54\% das áreas livres públicas existentes são de pequeno porte, entre 1.000 e $2.500 \mathrm{~m}^{2}$;

- as praças públicas existentes correspondem a apenas $0,80 \%$ da área urbanizada do município;

- os parques totalizam $4,5 \%$ da área urbanizada do município;

- a distribuição das áreas existentes é irregular, se agravando ainda mais nos extremos do município, e onde se concentra a população de renda mais baixa;

Em cima desses dados já abordados sobre o sistema de espaços públicos em São Paulo, podemos verificar que a antiga 
Administração Regional da Capela do Socorro, hoje subdivida em Capela do Socorro e Parelheiros, não apresenta uma situação muito diferente.

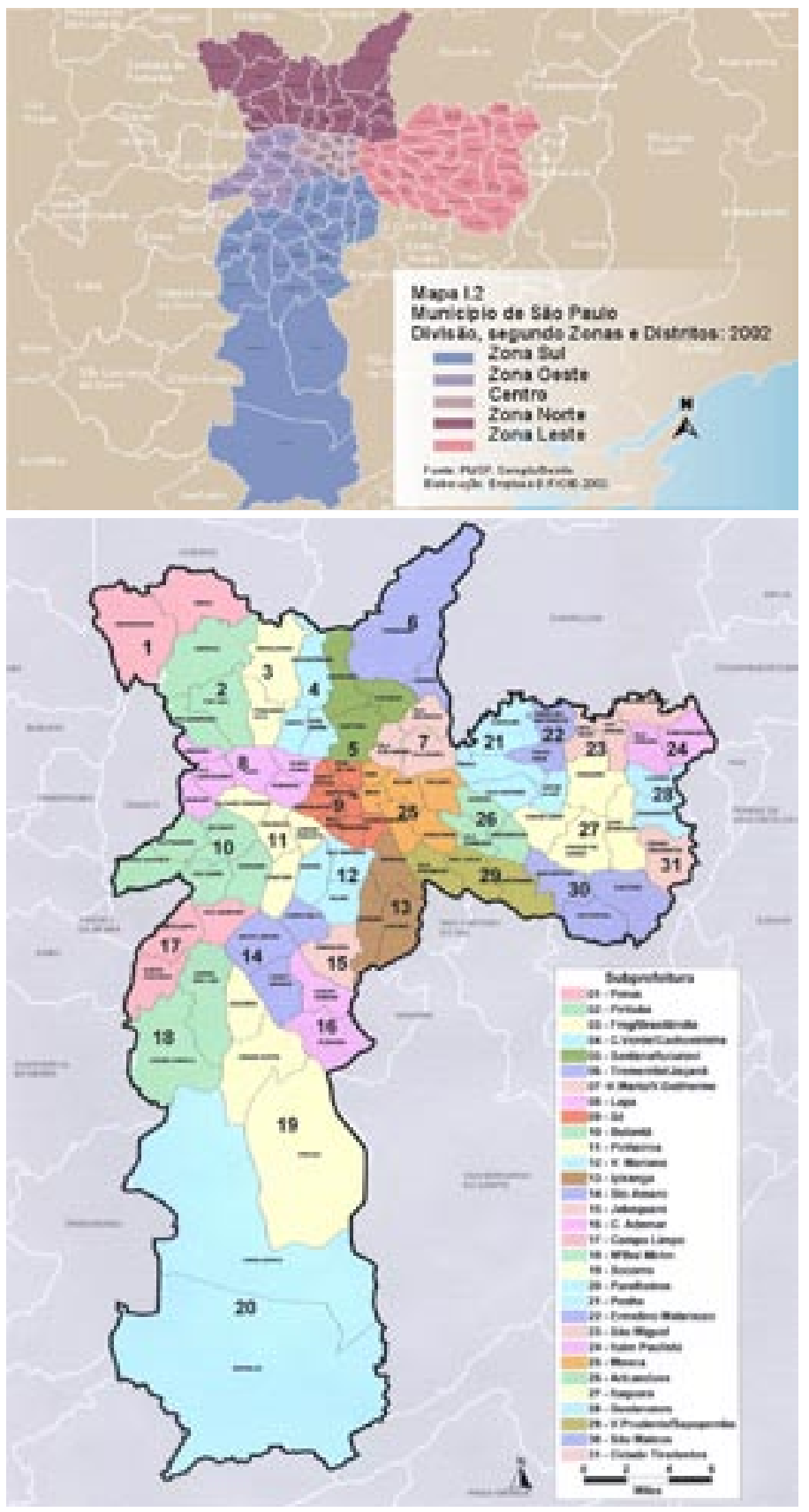

Fig. 102. Mapa indicativo das Sub-regiões do município de São Paulo.

Fonte: PMSP - Prefeitura do Município de São Paulo

Fig. 103. Mapa de São Paulo indicando a divisão das Subprefeituras.

Lei Municipal 13.399/02

Fonte: Secretaria Municipal de Planejamento - SEMPLA 
Tab. 8. Quadro quantitativo da estimativa populacional dos distritos da região da Capela do

$$
\text { Socorro. }
$$

Municipal do Planejamento - SEMPLA

Tab. 9. Dados Demográficos dos Distritos pertencentes às Subprefeituras.

Fonte: Dados da Secretaria Municipal do Planejamento - SEMPLA

\begin{tabular}{|c|c|c|c|c|c|c|c|c|}
\hline $\begin{array}{l}\text { Subpeefeituras/ } \\
\text { Distritos }\end{array}$ & 2000 & 2001 & 2002 & \multicolumn{2}{|c|}{2003} & 2004 & 2005 & 2010 \\
\hline $\begin{array}{l}\text { Municipio de } \\
\text { Så Paulo }\end{array}$ & 10.434 .258 & $10.52560 \% 1$ & 10.617945 & \multicolumn{2}{|c|}{10710.987} & 10.604067 & 10.235 .500 & 10 11.345.617 \\
\hline Parelheiros & 111.240 & 118.489 & 126.139 & \multicolumn{2}{|c|}{134.204} & 142.699 & 151.638 & 8203.428 \\
\hline Marsilac & 8.404 & 8.700 & 9.002 & \multicolumn{2}{|c|}{9.307} & 9617 & 9.930 & (1) 11.531 \\
\hline Paretheiros & 102.836 & 109.789 & 117.137 & \multicolumn{2}{|c|}{124.897} & 133082 & 141.708 & (8) 191.897 \\
\hline Socorro & 563.922 & 585.200 & 607.288 & \multicolumn{2}{|c|}{630.202} & 653.954 & 678.556 & $\left\{\begin{array}{l}814,514 \\
\text {, }\end{array}\right.$ \\
\hline Cidade Dutra & 191.389 & 193.511 & 195,532 & \multicolumn{2}{|c|}{197.448} & 199247 & 200.927 & 7207.295 \\
\hline Grajas & 333.436 & 353.136 & 373.762 & \multicolumn{2}{|c|}{395.337} & 417860 & 441.409 & 9974.244 \\
\hline Socorro & 39.097 & 38.554 & 37,994 & \multicolumn{2}{|c|}{37.418} & 36.827 & 38.220 & 20 32.975 \\
\hline Subpeefeitura & Distritos & $\begin{array}{r}\text { Populaçào } \\
\text { S }\end{array}$ & (4) Pepula & $\begin{array}{l}\text { acto } \\
2000\end{array}$ & Cres & $\begin{array}{r}\text { scimento } \\
\text { \& }\end{array}$ & $\begin{array}{l}\text { Arroa } \\
\left(\mathrm{Km}^{2}\right)\end{array}$ & $\begin{array}{l}\text { Densidade } \\
\text { Demogr. }\end{array}$ \\
\hline \multirow{4}{*}{ 19. Socerro } & Socorro & 38.375 & 39.01 & & & 1.67 & 12,90 & 3025 \\
\hline & $\begin{array}{l}\text { Cidade } \\
\text { Dutra }\end{array}$ & 176.262 & 1900 & & & 7.84 & 29.30 & 6.487 \\
\hline & Grajad & 272.684 & 331.91 & & & 21.74 & 92.00 & 3.608 \\
\hline & & 487.321 & 561.07 & & & & 13420 & 4.181 \\
\hline \multirow{3}{*}{ 20. Pareiheiros } & Marsilac & 7.416 & 8416 & & & 13,48 & 200,00 & 42 \\
\hline & Paveheris & 82.535 & 1024 & 493 & & 24,18 & 153,50 & 668 \\
\hline & & 89.951 & 11090 & 909 & & & 353.50 & 314 \\
\hline
\end{tabular}

Com uma densidade baixa, apesar de contar com quase $10 \%$ da população do município, devido às dimensões de seu território; e contar com as áreas de APA's e com 9 parques distribuídos por toda a Zona Sul e 41 CDM's só na região, essas estrutura de espaços livres acaba sendo insuficiente para a demanda de seus usuários.

Além disso, a Capela do Socorro possui somente 75 áreas livres aproximadamente, com área superior a $1.000 \mathrm{~m}^{2}$, sendo que dessas, a maioria não apresenta tratamento paisagístico. 
Outras áreas que se apresentam como pequenas praças são auxiliares do sistema viário (rotatórias e canteiros), com formas e tamanhos variados, onde não se identificam critérios hierárquicos para essa configuração.

Por possuir grande parte de seu território como área de proteção ambiental, o distrito se caracteriza como área privilegiada da cidade, porém seus espaços públicos são fragmentados e distribuídos de forma desigual dentro da região, comprovando o baixo índice de áreas públicas se comparada a outras Subprefeituras como a do Butantã, que contempla o bairro do Morumbi, e que apresenta o maior índice de áreas verdes públicas da cidade.
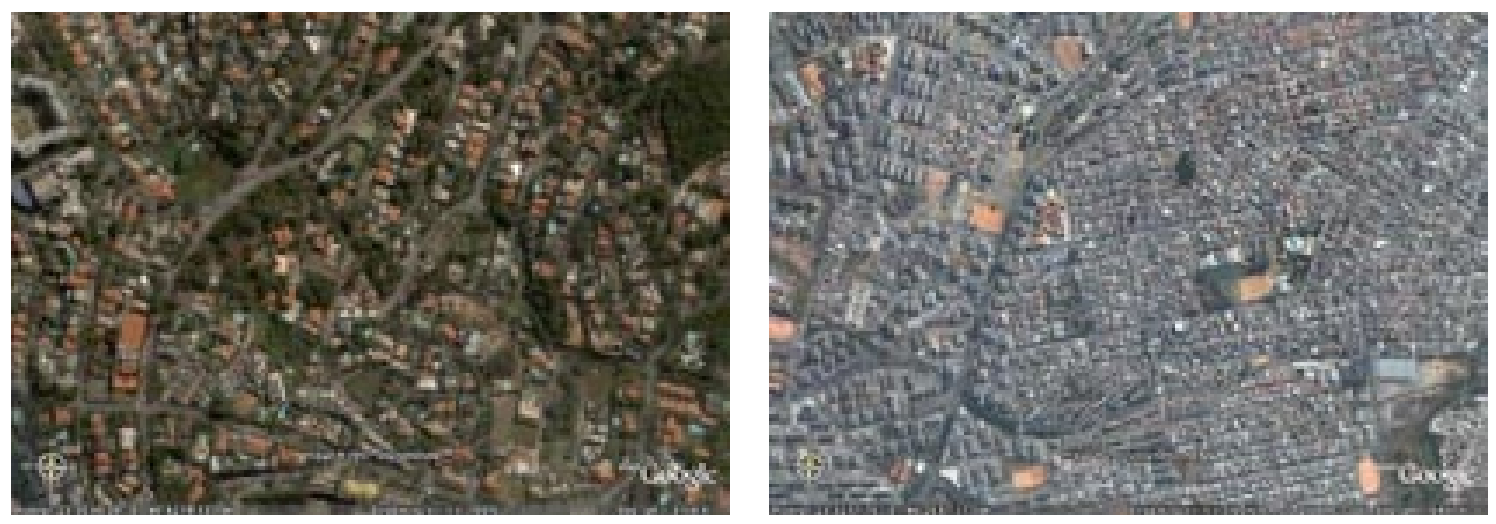

Nas fotos aéreas constata-se a aridez do distrito da Capela do Socorro. Se comparada ao bairro do Morumbi, além da presença de maior número de áreas livres públicas, os lotes apresentam dimensões que permitem o ajardinamento e o equipamento para o lazer privado, o que reduz a demanda de áreas públicas para convívio. Além disso, o bairro apresenta a implantação de arborização viária, decorrente da proposta dos bairros jardins e que se mantém até hoje, favorecendo o incremento de um efetivo sistema de espaços verdes no Fig. 104 e 105. Fotos aéreas comparativas do bairro do Morumbi, na zona sul da cidade, que apresenta um alto índice de áreas livres - à esquerda - a de Parelheiros no extremo sul do município que se configura pela somatória de loteamentos clandestinos, destacando-se nesta região a forte presença dos campinhos de futebol. bairro, mas infelizmente, essa não é a realidade da Capela do Socorro. 
Porém, hoje, a região apresenta uma ocupação predominantemente residencial, com uma população que se caracteriza de baixa renda, salvo alguns setores e média e alta renda.

Fig. 106. Mapa do Zoneamento do Município. Fonte: Secretaria Municipal do Planejamento - SEMPLA

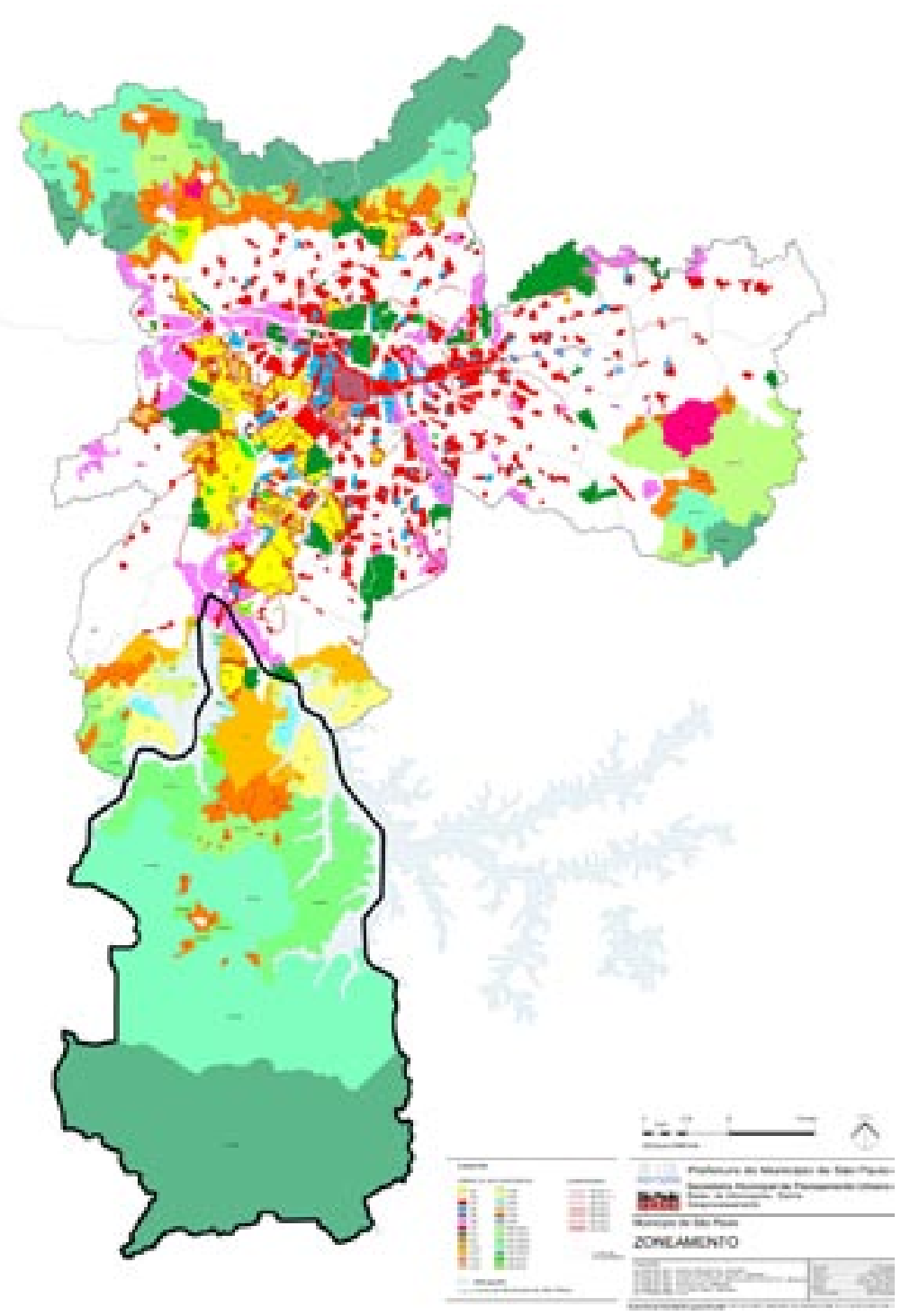




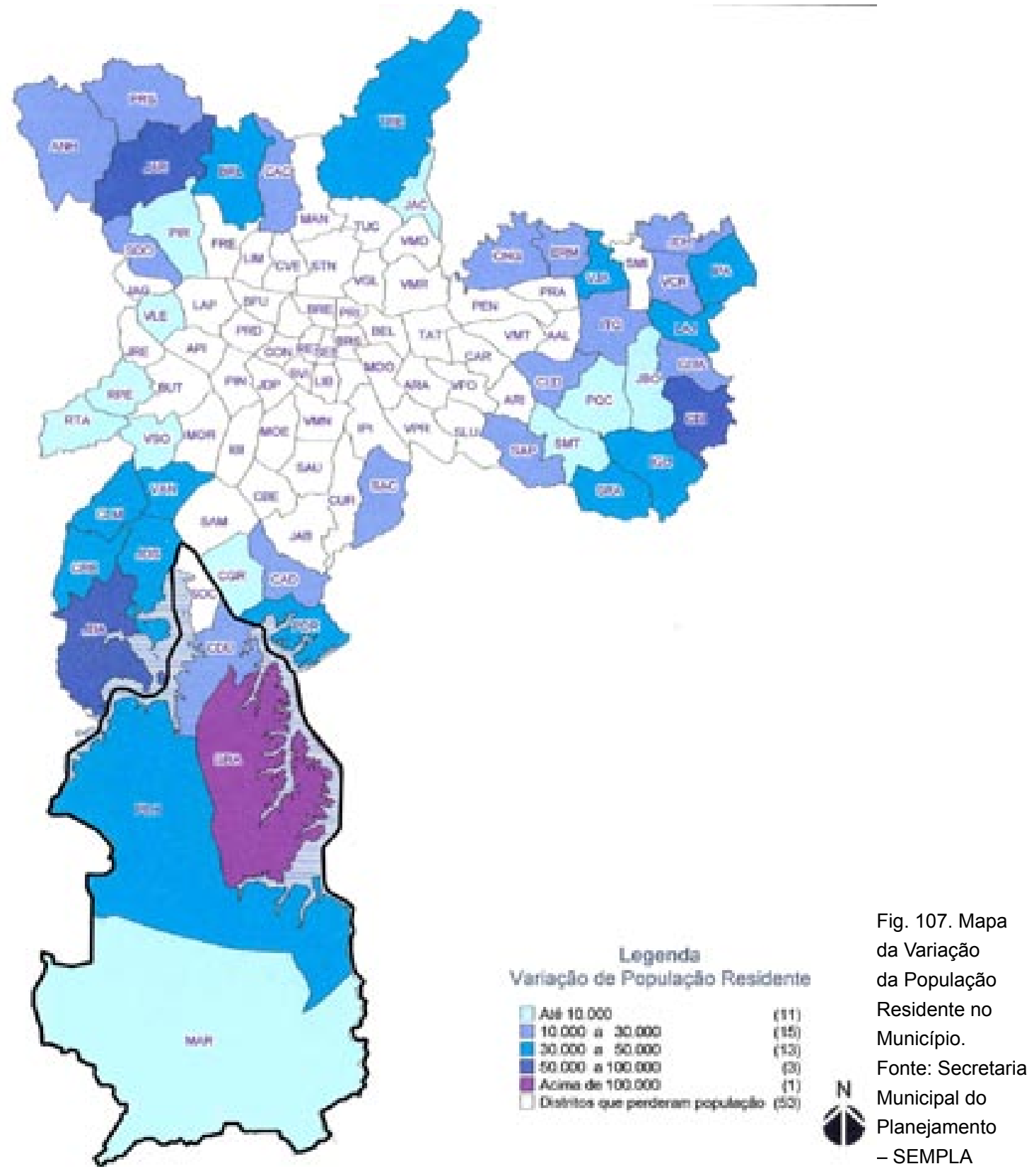




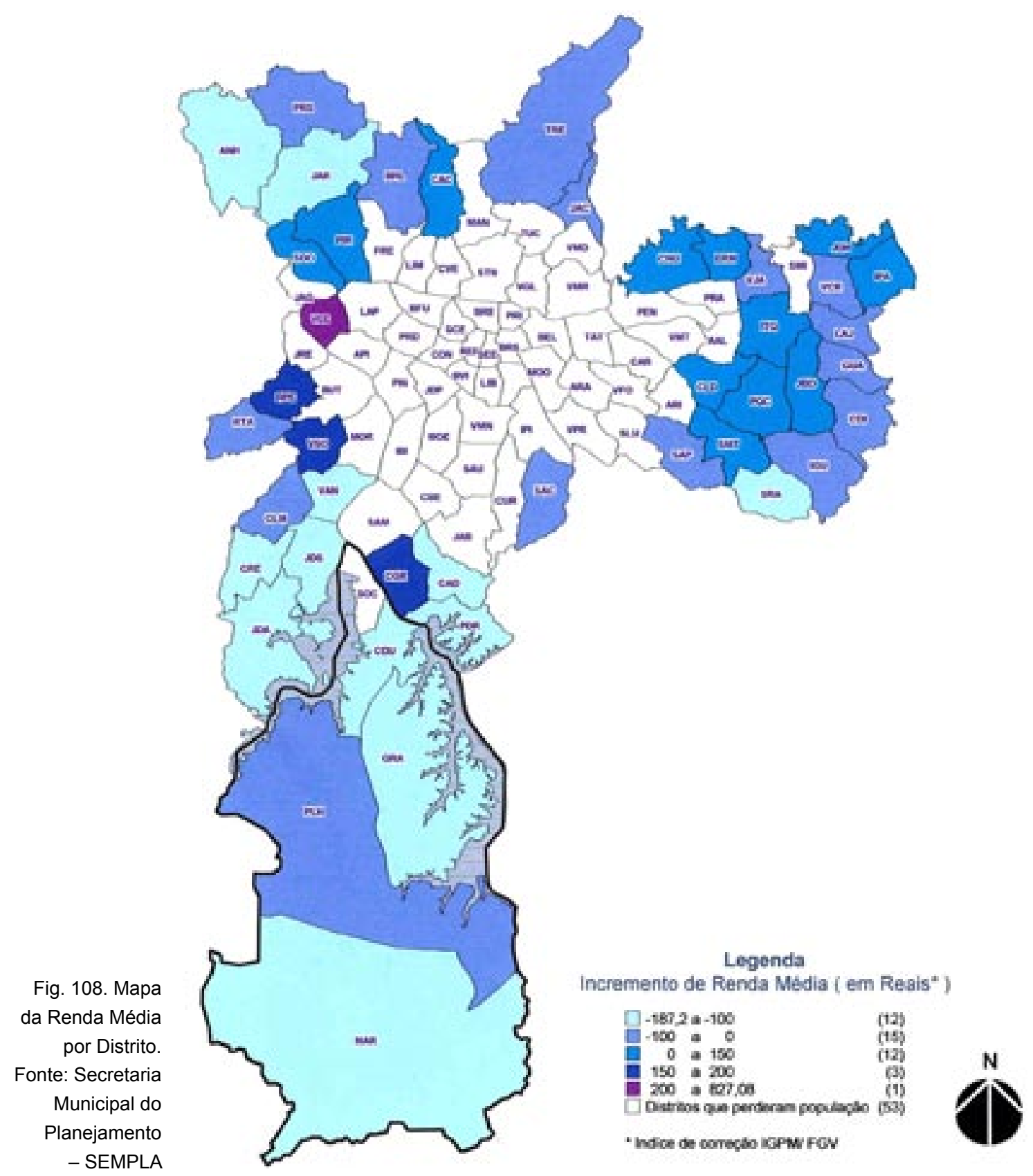




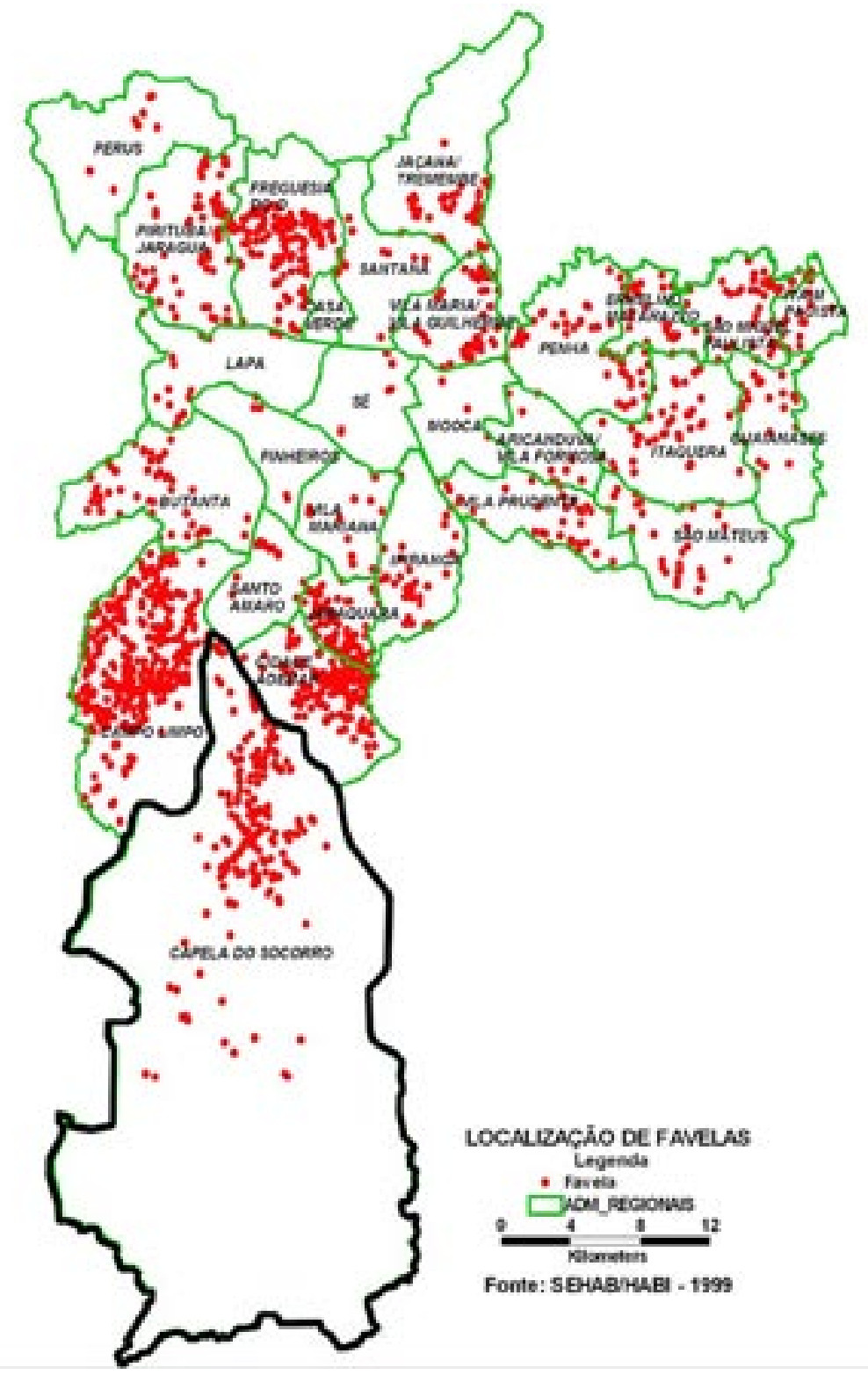

Assim, podemos dizer que parte da insuficiência de áreas livres públicas decorreu do grande numero de operações irregulares no parcelamento do solo urbano da região, nos quais os parâmetros legais referentes à destinação de áreas públicas ao município para a formação de parques e praças,
Fig. 109. Mapa da Distribuição de favelas por Administração Regional.

Fonte: Secretaria Municipal do Planejamento - SEMPLA 
foram sistematicamente desrespeitados e onde, o poder público participou dessa situação por meio de uma série de falhas nos procedimentos administrativos, desde o acompanhamento das propostas de loteamento até a fiscalização efetiva dessas áreas, entre outros tantos como:

- a legislação inadequada às características da região e ao processo de urbanização sofrido, uma vez que a região conta com a localização das represas Billings e Guarapiranga - responsáveis por parte do fornecimento de água da cidade; e da APA Capivari-Monos, com reservas ambientais da Mata Atlântica que correspondem a $62,4 \%$ da área do distrito. Apesar das restrições impostas pela legislação ambiental, a região apresenta urbanização intensa e desordenada, com parte da população residindo de forma precária, ocasionando sérios impactos ambientais;

- ausência de políticas publicas eficazes de produção de moradias populares e de urbanização de bairros periféricos que concentram a população de baixa renda;

- a usual prática do poder publico de anistiar infrações à lei, reforçando na sociedade que as irregularidades de hoje, um dia serão regularizadas.

Apesar disso, alguns espaços livres públicos foram gerados, só que grande parte deles teve seu destino original desvirtuado gerando a implantação de equipamentos comunitários como creches, escolas e outros; concessões de uso que disponibilizaram esses espaços para o uso de clubes e empresas; invasões dessas áreas com a formação de favelas e implantação de estacionamentos, além de outros usos. Assim, a falta de atuação do poder público deixou as áreas livres em "estoque" sem destinação, favorecendo a invasão e ocupação por outros usos.

Dentre os espaços livres que efetivamente foram implantados, muitos são inadequados às necessidades dos usuários por permanecerem sem equipamentos, mal equipados 
ou sem uma manutenção regular, desfavorecendo assim o seu uso.

No sistema viário, faltam vias principais de ligação e conexão entre bairros e a descontinuidade entre as vias existentes contribui para a distribuição irregular das vias arteriais, uma vez que o prolongamento delas ocorreu a cada nova gleba parcelada. A articulação viária foi realizada por meio de diferentes planos, com a abertura de novos eixos de circulação. A configuração do sistema de vias coletoras e locais é de difícil identificação, com predominância de reticulados ortogonais que se repetem, porém com vias muitas vezes desconectadas.

Assim, o sistema de espaços livres públicos na Capela do Socorro tem sua configuração marcada por deficiências na distribuição, na adequação e na hierarquia de suas áreas. Podese também dizer que, além das dificuldades acima descritas, a fragilidade desse sistema se dá pela falta de articulação entre os diversos órgãos municipais e estaduais e pela diluição de responsabilidades na gestão desses espaços.

\section{A c o n t r i b u i çã o d o Programa Centros de B a i r r o}

Diante do quadro do sistema de espaços públicos da cidade de São Paulo, ou melhor, da inexistência de um plano geral, sistematicamente estruturado, que permitisse a configuração de um sistema de espaços livres públicos destinados à circulação, à conservação ambiental, ao convívio e ao lazer urbanos, passível de atender as demandas que se consolidaram com a urbanização e o adensamento populacional, principalmente nas periferias da cidade; o Programa Centros de Bairro, idealizado e executado durante a gestão Marta Suplicy (2001-2004), buscou 
implantar uma rede de espaços públicos, formada por 49 praças nas periferias da cidade, que funcionassem como pequenos embriões na formação de um futuro sistema de espaços livres articulados com a estrutura pública, e porque não privada, já existente.

As praças, que foram distribuídas de forma quase homogênea, pelas diferentes zonas da cidade, e de acordo com o grau de carência dessas áreas, foram idealizadas para contemplar as diferentes demandas da população, com a criação de áreas de circulação, lazer, pratica de esportes, permanência, convivência comunitária, embelezamento, além da preocupação com o aumento da biodiversidade e da conservação ambiental. Havia uma preocupação em superar as deficiências de implantação desses espaços nas regiões mais carentes e uma estratégia para a implantação de mais áreas. Porém, o programa não teve o apoio da gestão seguinte para a ampliação desse "sistema" e acabou sendo "engavetado" como tantos outros planos já idealizados para a cidade. ${ }^{24}$

Além de ter levado melhorias ambientais a áreas da periferia e consequentemente, algumas transformações sociais e culturais, de uma forma mais estruturada, a maior contribuição do Programa Centros de Bairro ao sistema de espaços livres e à cidade foi a mudança do olhar para a cidade, onde o projeto paisagístico não foi visto apenas como um tratamento estético embelezador da cidade, mas como um componente de construção do meio ambiente urbano, capaz de transformar áreas e criar lugares de expressão da cidadania, com espaços livres públicos democráticos e qualificados, possibilitando a interação e o convívio social entre a comunidade.

As parcerias realizadas com outros órgãos e secretarias municipais geraram a incorporação de projetos e tratamentos das áreas públicas livres decorrentes de outros planos, como a

${ }^{24}$ A nova fase de implantação do programa contaria com mais aproximadamente 70 praças. "nova" preocupação da CET com os canteiros e ilhas do sistema viário. 
Efetivamente, o Programa acabou não funcionando como um sistema, mas esses projetos puderam recategorizar, requalificar ou ainda articular estes espaços a outros; e criaram símbolos ou "inovações" que mudaram o olhar dos cidadãos sobre seu bairro - ou seus lugares do cotidiano, sobre sua identidade.
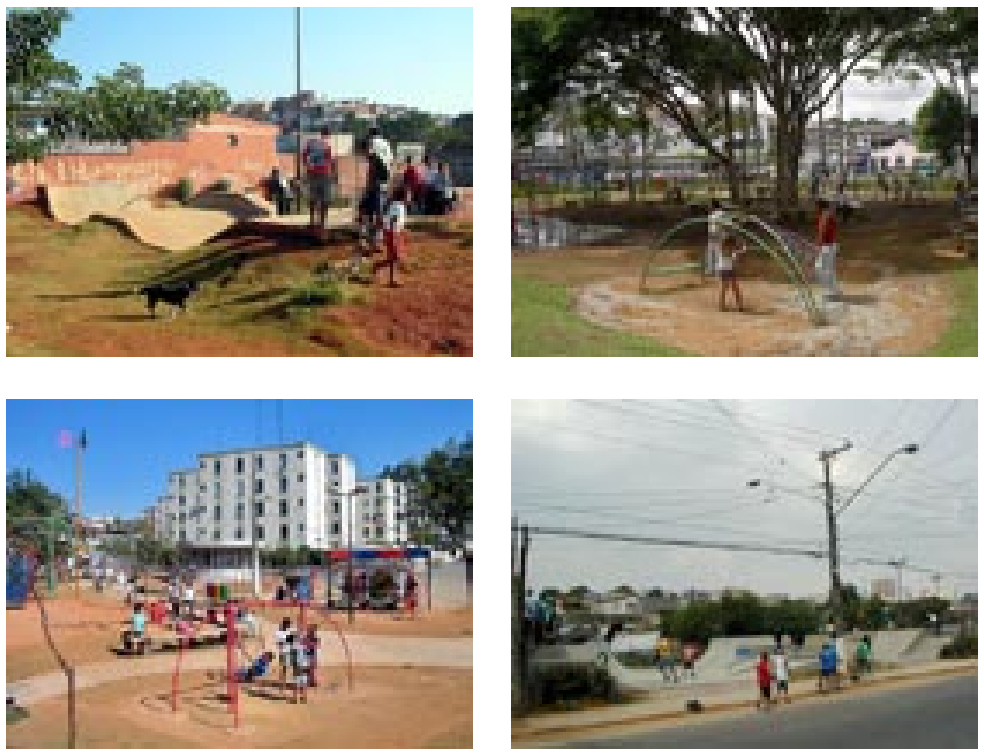

A s praç a s

Como partes integrantes do Sistema de Espaços Livres da Capela do Socorro, serão analisadas aqui as praças desse setor da Zona Sul de São Paulo, pertencentes a uma parte do primeiro lote de intervenções do Programa Centros de Bairro: Conjunto Habitacional Brigadeiro Faria Lima (o Bororé), a Av. Ipanema $x$ Av. dos Lagos, a Várzea do Córrego São José e a Praça do Trabalhador (hoje pertencente a atual subprefeitura de Parelheiros).

Além de apresentarem características físicas bem diferentes, estas praças tiveram apropriações diversas e estão apresentadas aqui como um diagnóstico, além de um relato da
Fig. 110, 111 e 112.

Lgo. do Araribá.

Foto: Lopez, junho 2003;

Lgo. do Campo Limpo.

Foto: Lopez, 2003;

Pça do Encontro.

Foto; Lopez, 2003.
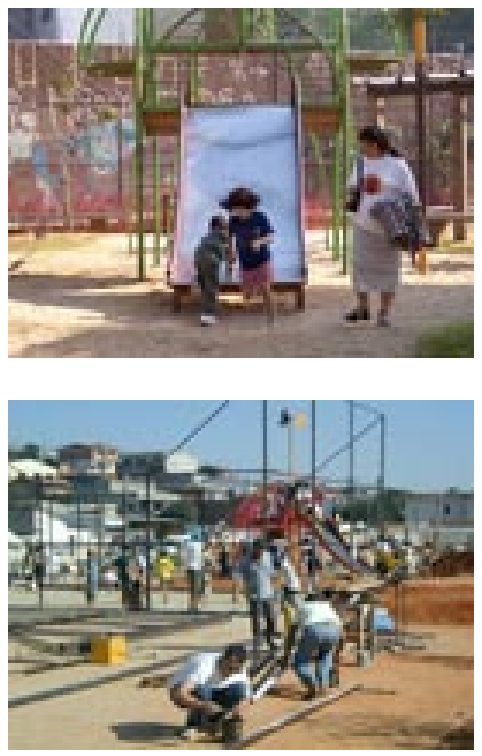

Fig. 113, 114 e 115.

Cidade Tiradentes.

Foto: Lopez, junho 2003;

Pça. Antonio de Castro Lopes.

Foto: Lopez, março 2003;

Pça Bassano Del Grappa.

Foto: Lopez, junho 2003. 
experiência de projeto e implantação do Programa Centros de Bairro, no cotidiano dessas áreas.

Fig. 116. Fotomontagem

da região da Capela do Socorro - Linha tracejada em amarelo indica a divisão das subprefeituras, e em laranja as áreas de intervenção do Programa Centros de Bairro.

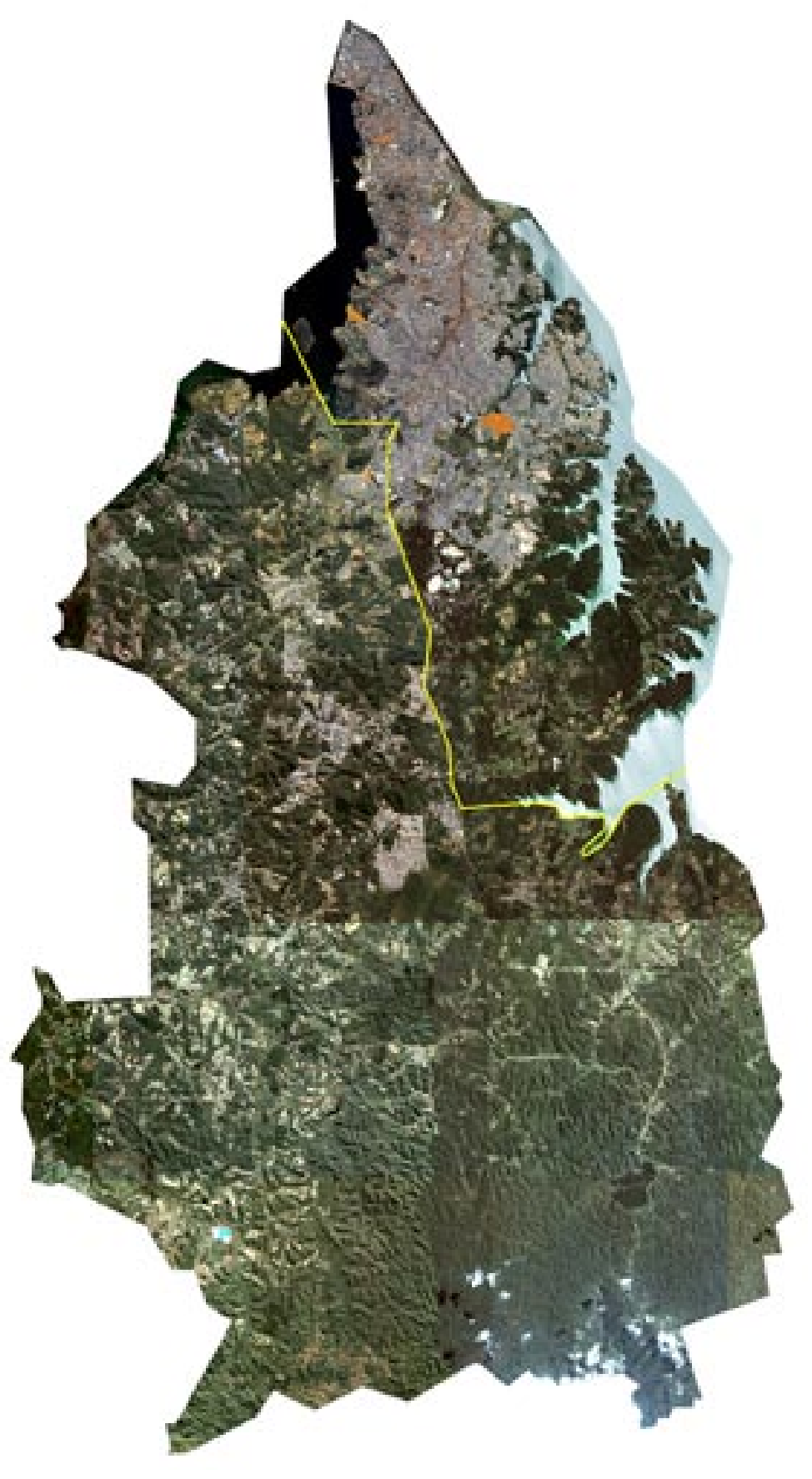




\section{o conjunto habitacional brigadeiro faria}

\section{lima - o bororé}

Localizado no extremo sul da cidade, no bairro do Grajaú, distrito da Subprefeitura da Capela do Socorro (zona sul), próximo a São Bernardo do Campo e às margens da Represa Billing e a Represa de Guarapiranga, o Bororé tem seu principal acesso pela Av. Belmira Marin, via secundária da Av. Sen. Teotônio Vilela e uma área aproximada de $345.050,00 \mathrm{~m}^{2}$, com ocupação mista de conjunto verticais e horizontais, totalizando aproximadamente 1.334 apartamentos e 1.368 casas, com uma população estimada de 13.510 habitantes.

A grande maioria da população do distrito é composta por crianças, adolescentes e jovens de até 29 anos com um percentual de $59,63 \%$, índice que supera a média do município. Desses, $28,71 \%$ são jovens entre 15 e 29 anos. Estes números nos mostram que mais de 1/4 da população do distrito do Grajaú é composta por jovens em fase de formação, que necessitam de atenção reforçada no que diz respeito a programas de inclusão e participação, principalmente por meio de educação complementar, capacitação técnica e geração de trabalho e renda, para que se possa vislumbrar uma alternativa igualitária frente às ofertas que a criminalidade oferece.

Segundo informações cedidas pela Coordenadoria de Educação, os tipos de violência mais comuns no entorno da escola, por ordem de freqüência, são: porte ilegal de armas, estímulo à utilização de bebidas alcoólicas, agressão física, furtos, homicídios, atentado ao pudor, incentivo à prostituição, toque de recolher e depredação do equipamento escolar.

Os equipamentos públicos de esporte e lazer são insuficientes na região, considerando o grande número de crianças, adolescentes e jovens (150.558 pessoas) que utilizam esses espaços. Os CEUs, apesar de oferecerem opções de 
cultura e lazer, também são insuficientes e estão localizados em regiões distantes da grande concentração populacional.

INSERIR TABELA DE EQUIPAMENTOS PÚBLICOS NO DISTRITO

Além do Grajaú ser o distrito mais populoso de São Paulo, é também o que possui o maior número de pessoas vivendo em favelas: 59.306 pessoas (CENSO 2000/IBGE), isto é, $18 \%$ da população do distrito, ocupando uma grande área de mananciais. Na listagem fornecida pela atual Coordenadoria de Planejamento da Capela do Socorro estão mapeados 84 bairros e 130 favelas situadas no distrito, com aproximadamente $80 \%$ do território composto por construções irregulares.

AAv. Belmira Marim é o eixo central do distrito, onde, além de ser a área mais equipada do distrito, se concentra a maior parte do comércio. Podemos observar melhores condições urbanas em seus primeiros quilômetros e arredores (parte norte do distrito); na medida em que avançamos em direção à Represa Guarapiranga, ou mais para o sul do distrito, o cenário passa a ser praticamente rural, se deteriorando consideravelmente e evidenciando as graves condições em que as regiões mais afastadas se encontram.

Boa parte destas regiões, apesar de significativamente ocupadas, está desprovida de equipamentos públicos e são parcialmente atendidas pelos poucos programas sociais que atingem a região. É aí que nos deparamos com o Bororé, pertencente à grande produção de conjuntos habitacionais ocorrida entre as décadas de 1970-1980, o Conjunto Habitacional Brigadeiro Faria Lima, mais conhecido pelo programa como Bororé, foi um dos primeiros conjuntos habitacionais COHABSP (Companhia Habitacional de São Paulo), inaugurado em 
1976. Estes conjuntos receberam e ainda recebem uma crítica severa a partir do juízo de valores do urbanismo contemporâneo, principalmente pelo tipo e locais de implantação onde a regra é o descaso e até desrespeito à população dessas áreas pela falta de articulação com a trama urbana do entorno, a monotonia espacial gerada pela repetição das unidades habitacionais, a falta de equipamentos públicos de uso coletivo e a não implantação das áreas verdes, geralmente propostas no projeto.
Fig. 117 e 118. Acesso principal ao conjunto do Bororé é feito pela Avenida Belmira Marin, via secundária da Av. Teotônio Vilela. À direita mapa do sistema viário do conjunto.
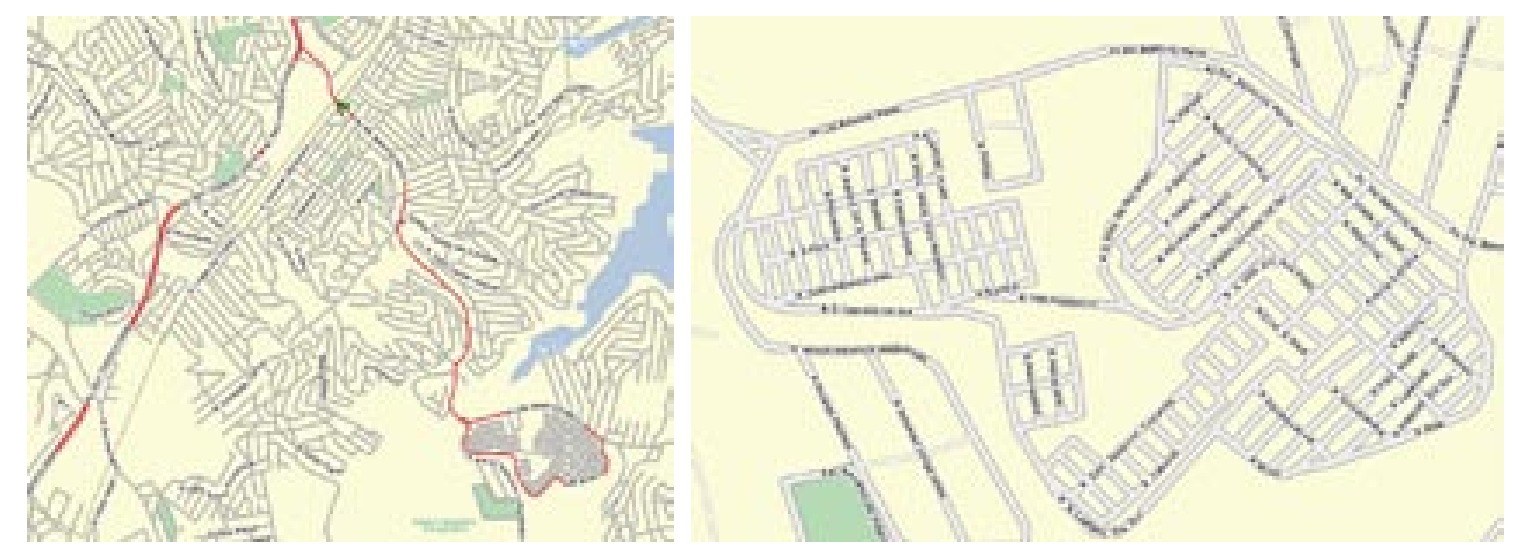

O bairro possui uma relativa infra-estrutura básica, e conta com posto de saúde, posto da guarda municipal, escolas de ensino fundamental e creche. Porém, as áreas destinadas à implantação de áreas verdes encontravam-se invadidas pela ocupação de estacionamentos privados, decorrentes da falta dessas áreas nos conjuntos verticais; ou completamente abandonadas pelo descaso do poder público. (Fig. 121 a 126)

Tanto os conjuntos verticais quanto os lotes residenciais
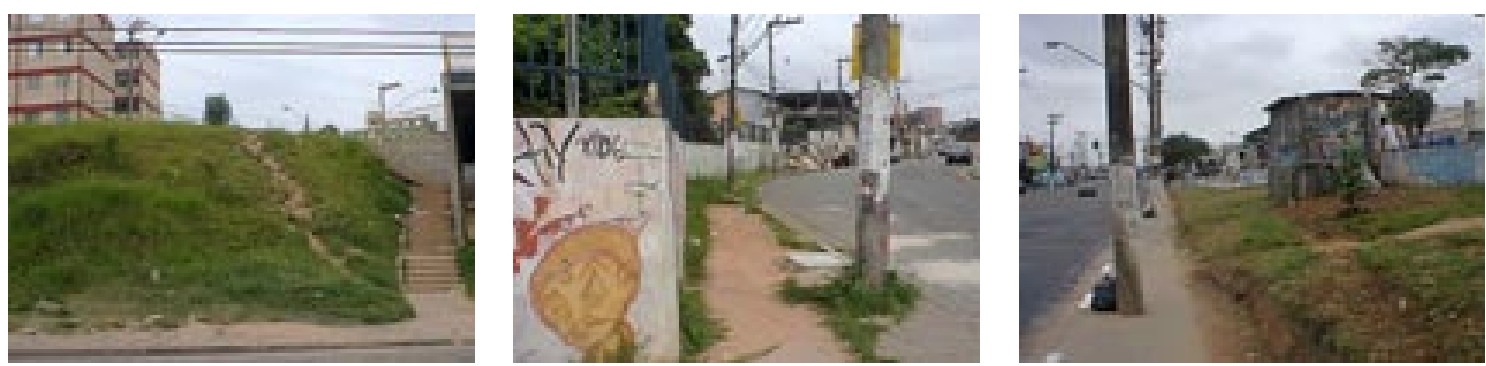

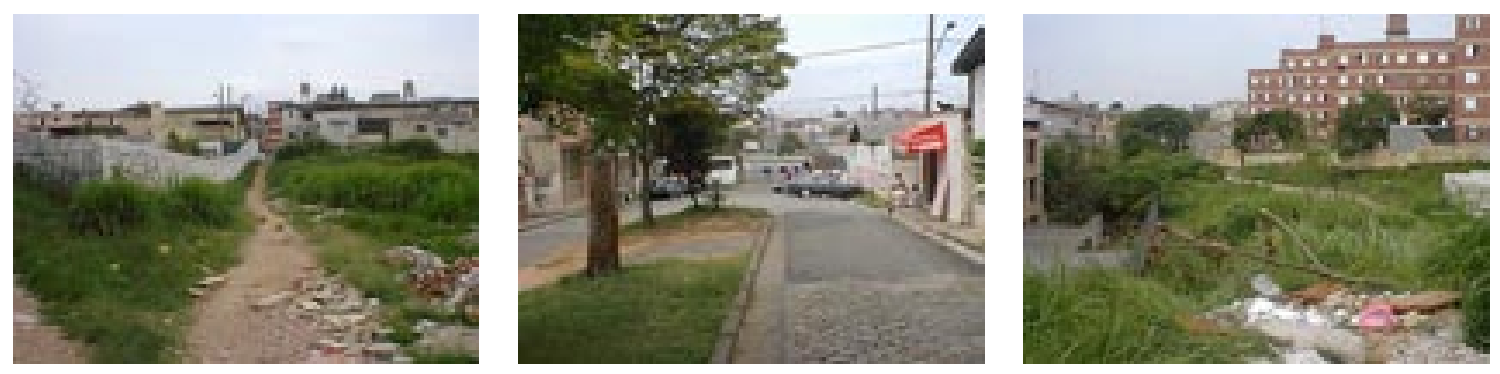

Fig. 121 a 126. (nesta página e na anterior) Fotos das áreas livres públicas do conjunto antes das intervenções, em estado de total descaso do poder público, servindo muitas vezes como bota-fora. Fotos: Arquivo EMURB, 2001 apresentam alta taxa de ocupação do solo, denotando o processo de ampliações realizadas pelos moradores, os famosos "puxadinhos"; e no caso dos conjuntos verticais a construção de garagens em todos os tipos de espaços restantes dos terrenos.

A principal rua de acesso ao conjunto, que marca o seu limite com os bairros vizinhos - Rua São Caetano do Sul é caracterizada pela ocupação de comércios e pequenos serviços, além da presença de um mercado de bairro e de uma igreja. Neste local, aos sábados, é realizada a feira livre do bairro.

As ruas adjacentes apresentam vários tipos de comércio informal. Barracas instaladas em caráter semi-permanente, na esquina de um dos limites do conjunto com a Av. Belmira Marin, junto com os pontos finais de algumas linhas de ônibus vendem-se os mais variados produtos, desde frutas e legumes até pequenas peças do vestuário e cd's pirateados.

Assim, neste contexto bastante diversificado, o Programa Centros de Bairro implantou 14 pequenas praças, totalizando $46.000 \mathrm{~m}^{2}$, em áreas residuais do traçado viário e que haviam sido doadas à prefeitura como áreas verdes para a implantação de espaços livres para a recreação. Devido à falta de fiscalização, entre outros fatores, vistos nos capítulos anteriores; esse fato não se concretizou, e essas áreas encontravam-se abandonadas ou invadidas. A intervenção buscou então criar espaços de convívio e circulação, e implantou play-grounds, pista de skate, quadras poliesportivas e áreas ajardinadas, além de iluminação e da criação de uma pequena horta comunitária. 


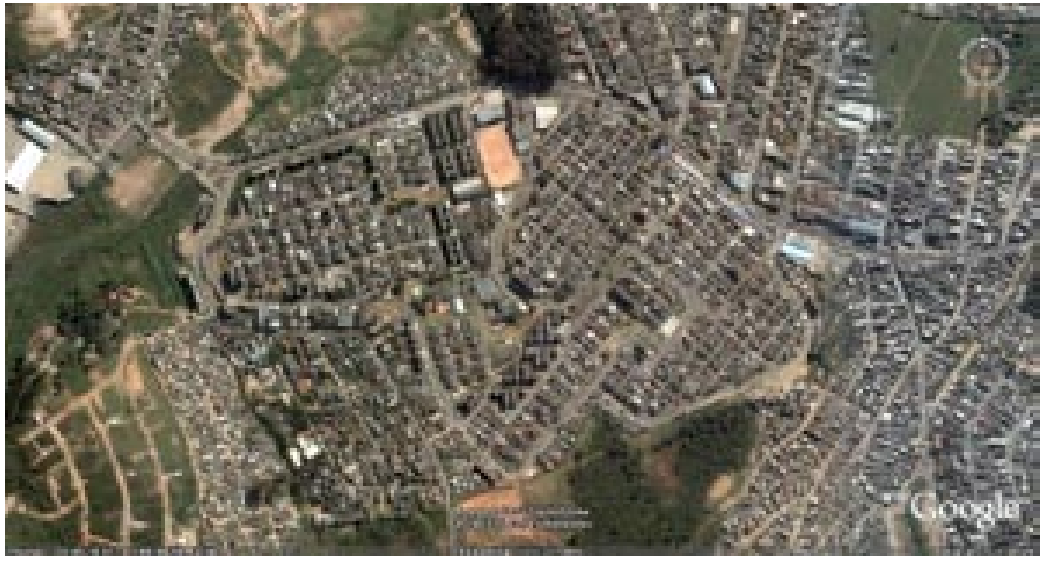

Fig. 127. Foto aérea do conjunto com as praças já implantadas.

Fonte: Google Earth, 2002

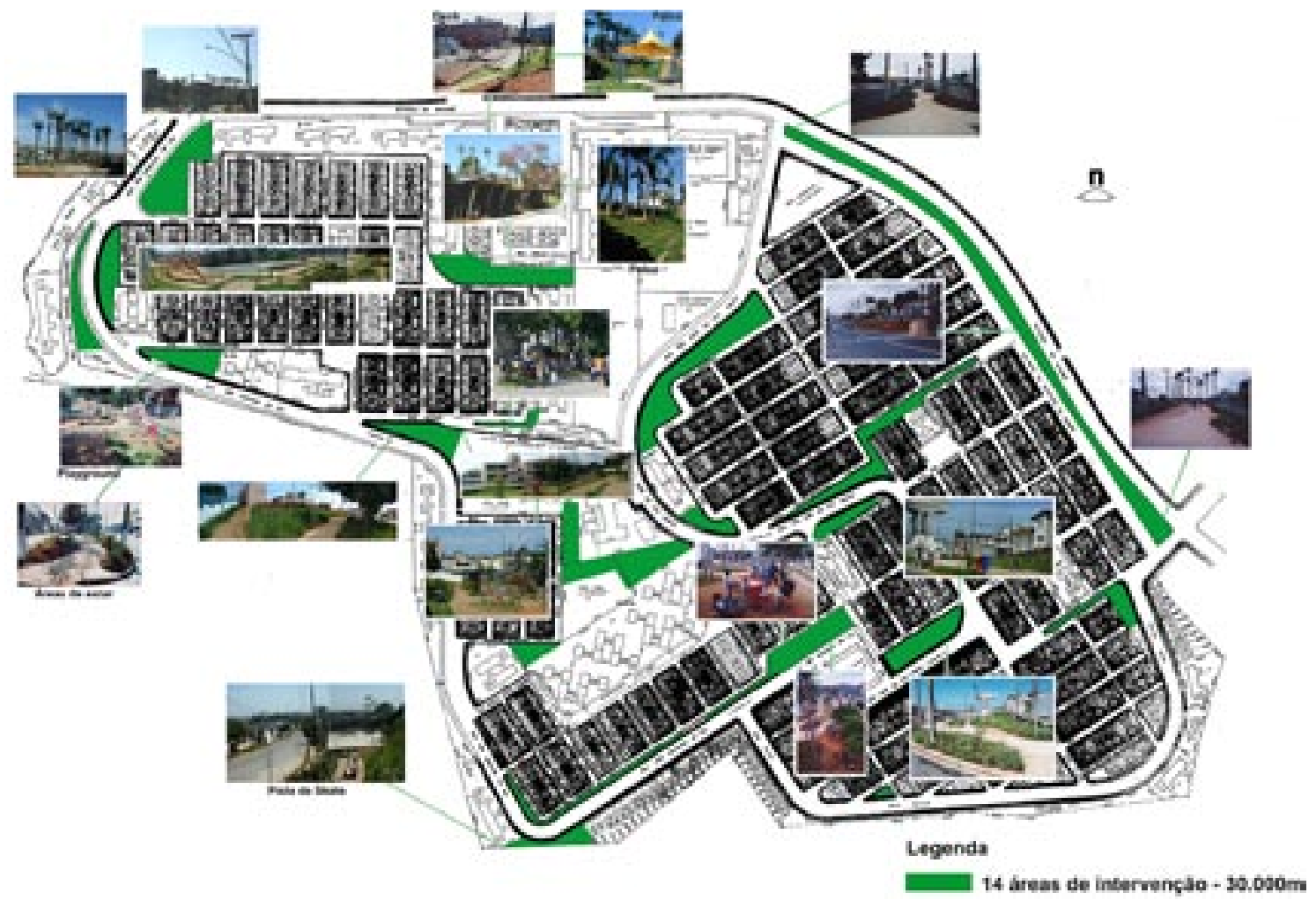

O resultado foi que não só mais uma pequena parcela Fig. 128 da população se apropriou desses espaços, mas sim toda a comunidade do conjunto, de diferentes formas, desde crianças que vão às praças para se divertirem nos play-grounds até idosos 
que jogam xadrez e cartas em mesas instaladas, passando por organizações do bairro que promovem feiras de artesanato ou noites musicais.
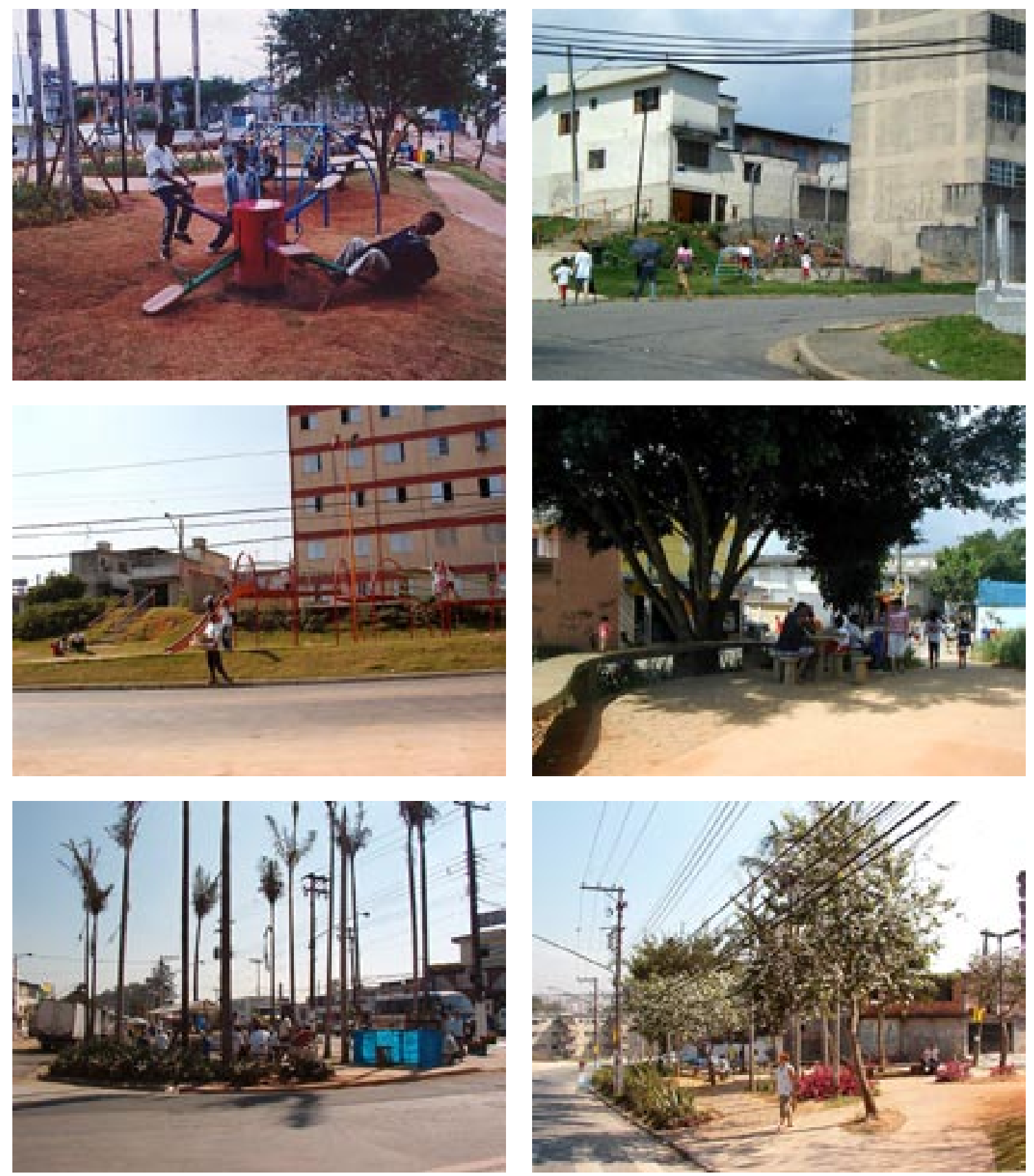


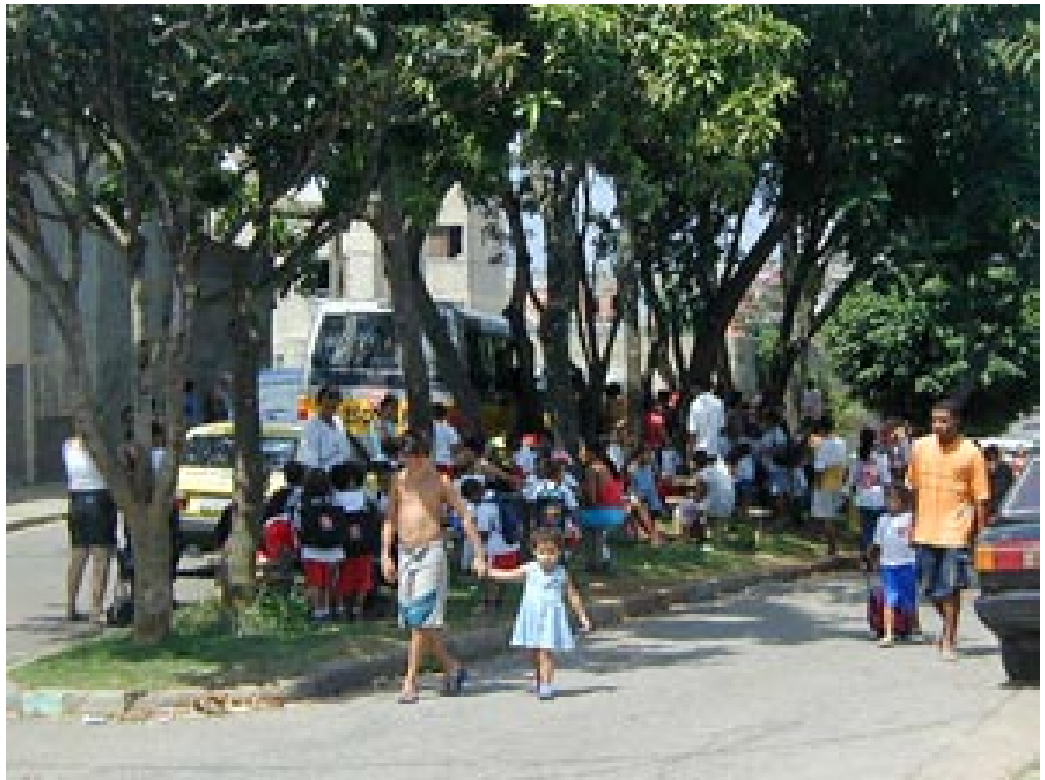

Entre outros casos do conjunto, as professoras das creches e escolas de $1^{\circ} \mathrm{grau}$ juntamente com os arquitetos responsáveis pela obra voltaram os seus portões para um antigo "beco" que se transformou em horta. Este tipo de apropriação acabou resultando na diminuição dos casos de violência no local, pois provocou o afastamento do tráfico de drogas que ocupava a área e que foi repelido pelo uso da população. (Fig. 136 a 140)
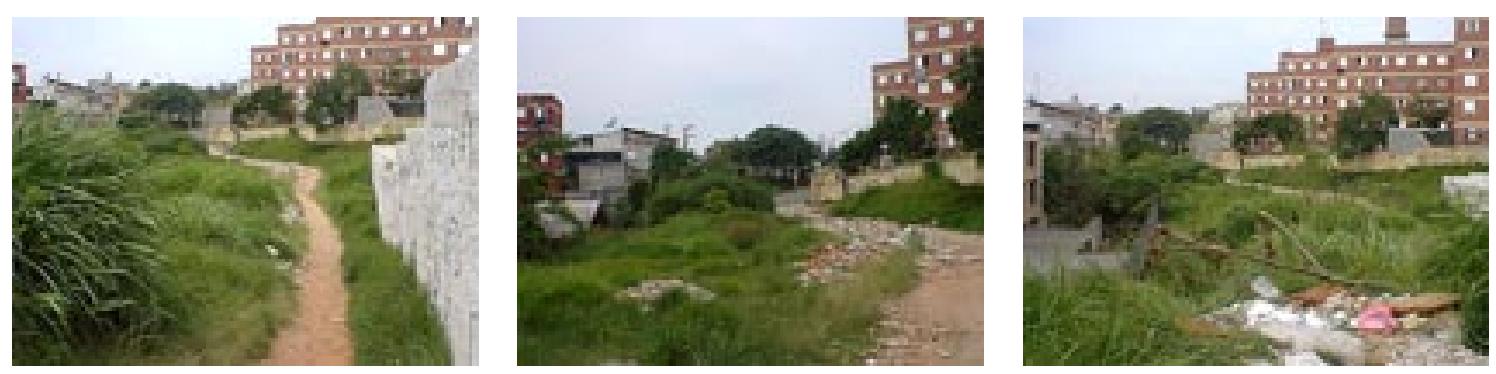

A manutenção dos canteiros, realizada hoje pelos moradores do entorno das praças, mesmo com o plantio aleatório das espécies herbáceas e arbustivas, denota a ação dos usuários ao longo do tempo após a entrega das áreas à população, indicando a participação voluntária dos moradores,
Fig. 129 a 135. (nesta página e na anterior). Fotos do cotidiano das diferentes praças do Bororé, com algumas cenas de apropriação desses espaços pela população. Destaque para as crianças sentadas no banco da praça junto á uma das escolas esperando o sinal de entrada, numa intervenção "simples", com a exclusiva implantação de um banco e plantio de grama numa área que antes encontrava-se abandonada e com mato alto atingindo $80 \mathrm{~cm}$ de altura.
Fig. 136, 137 e 138. Fotos da área da horta antes da intervenção.

Foto: Arquivo da Emurb - 2001 
Fig. 139 e 140. Fotos da área da horta depois da intervenção. Foto: Lopes, 2003

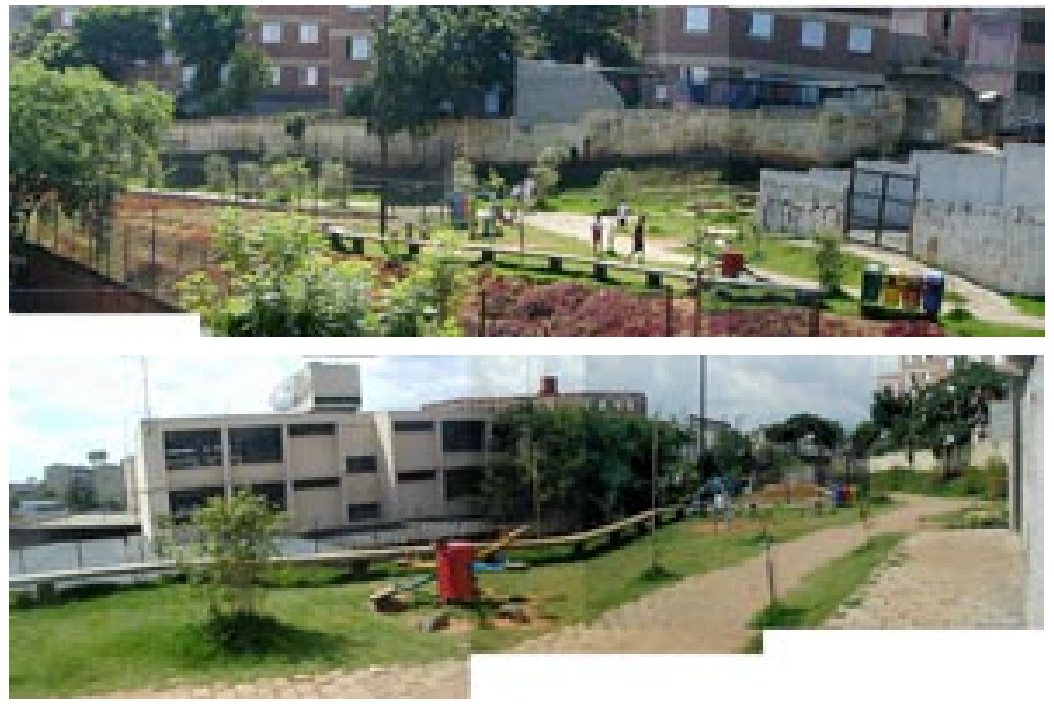

que "cuidam" das praças, estabelecendo uma identidade com o lugar; remetendo a uma noção de bem-público e de responsabilidade comum entre os moradores locais e o poder público; mesmo que inconscientemente.

As praças são intensamente utilizadas, principalmente nos horários de entrada e saída das escolas e da creche, no fim da tarde e aos domingos, servindo de ponto de encontro das mais diversas faixas etárias, e de ambos os sexos.

As mais variadas atividades se realizam nessas áreas: as crianças se divertem nos playgrounds; adolescentes e adultos praticam esportes na quadra poliesportiva; as mulheres se encontram na área próxima ao mercado e à feira livre; idosos descansam nos bancos vendo o tempo passar; as crianças menores esperam o horário de entrada na escola sentadas no banco da "pracinha" de frente, mulheres (moradoras) vendem cachorro-quente e sorvete de saquinho num comércio informal junto à área da guarda municipal... enfim, o cotidiano se realiza em diferentes formas de apropriação dos espaços; se revelando um universo bastante rico. 


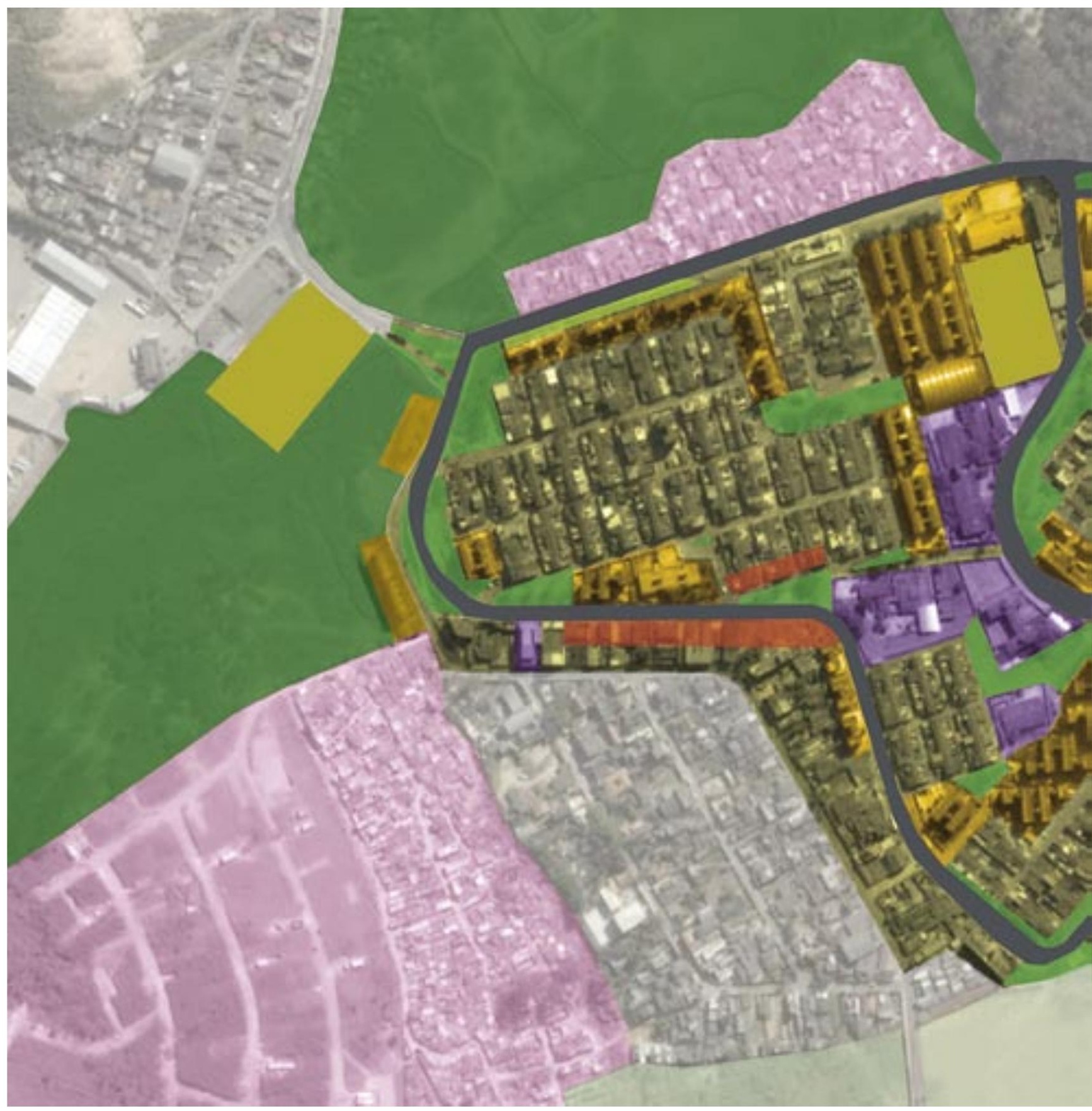




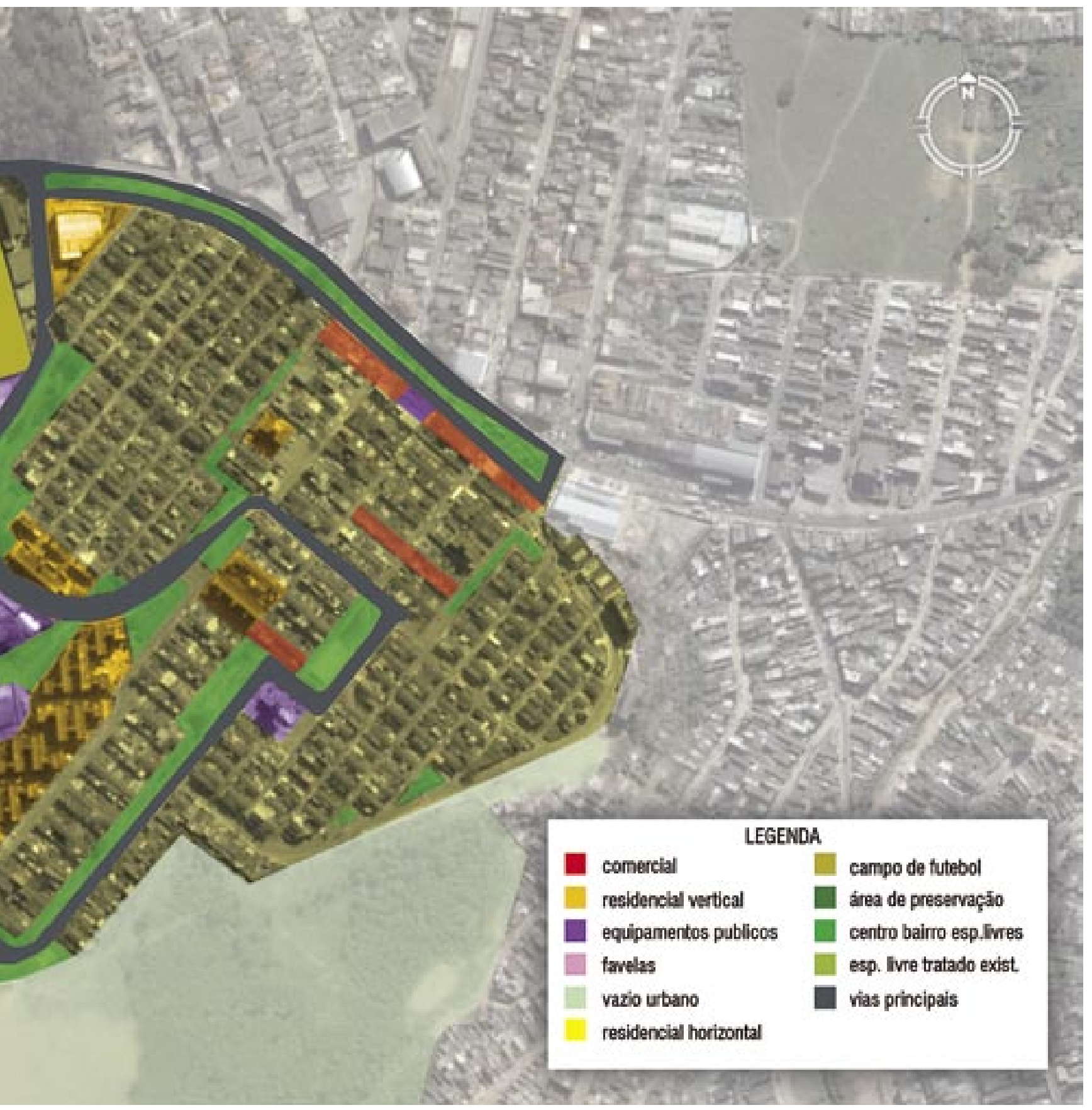




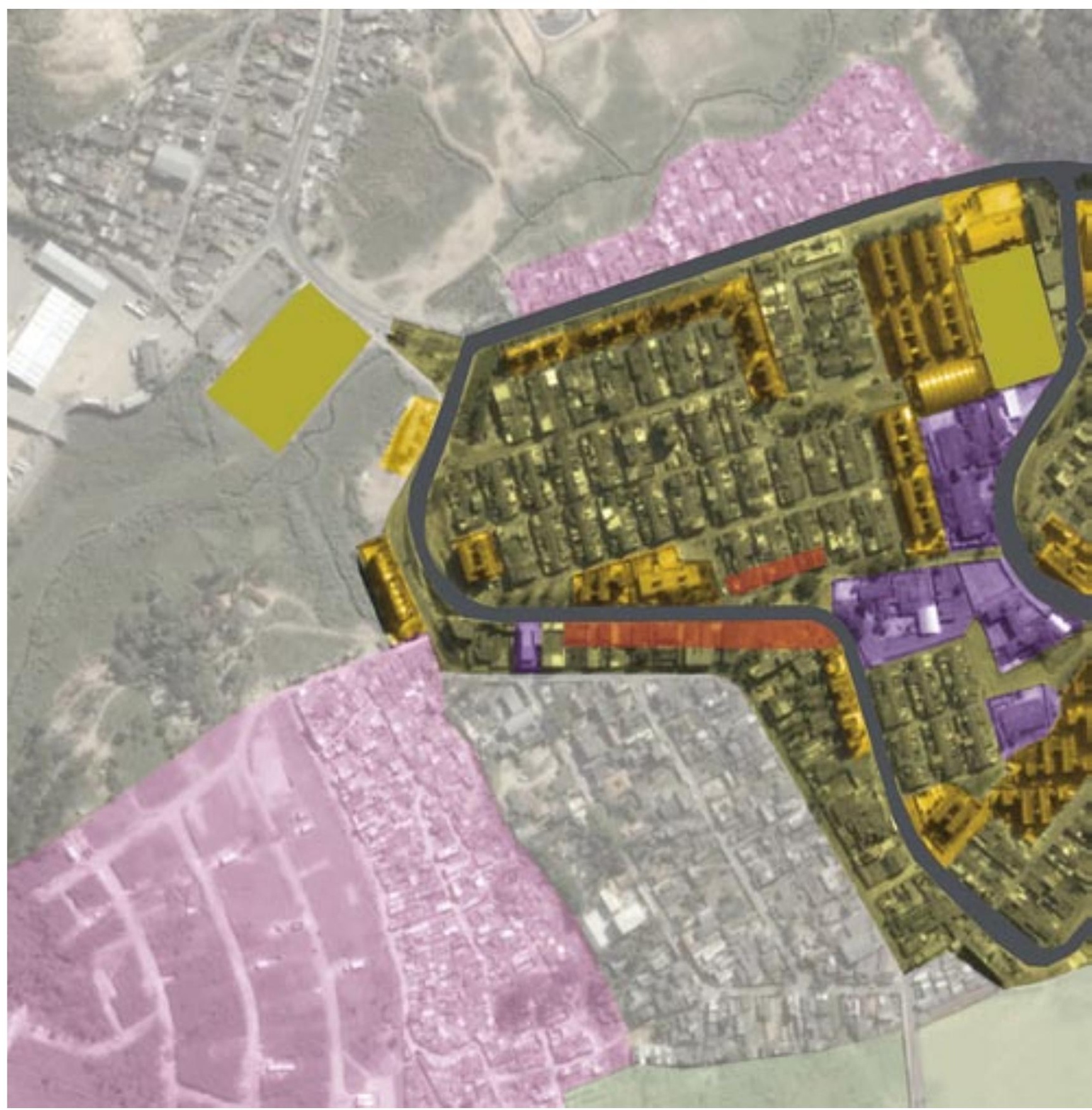




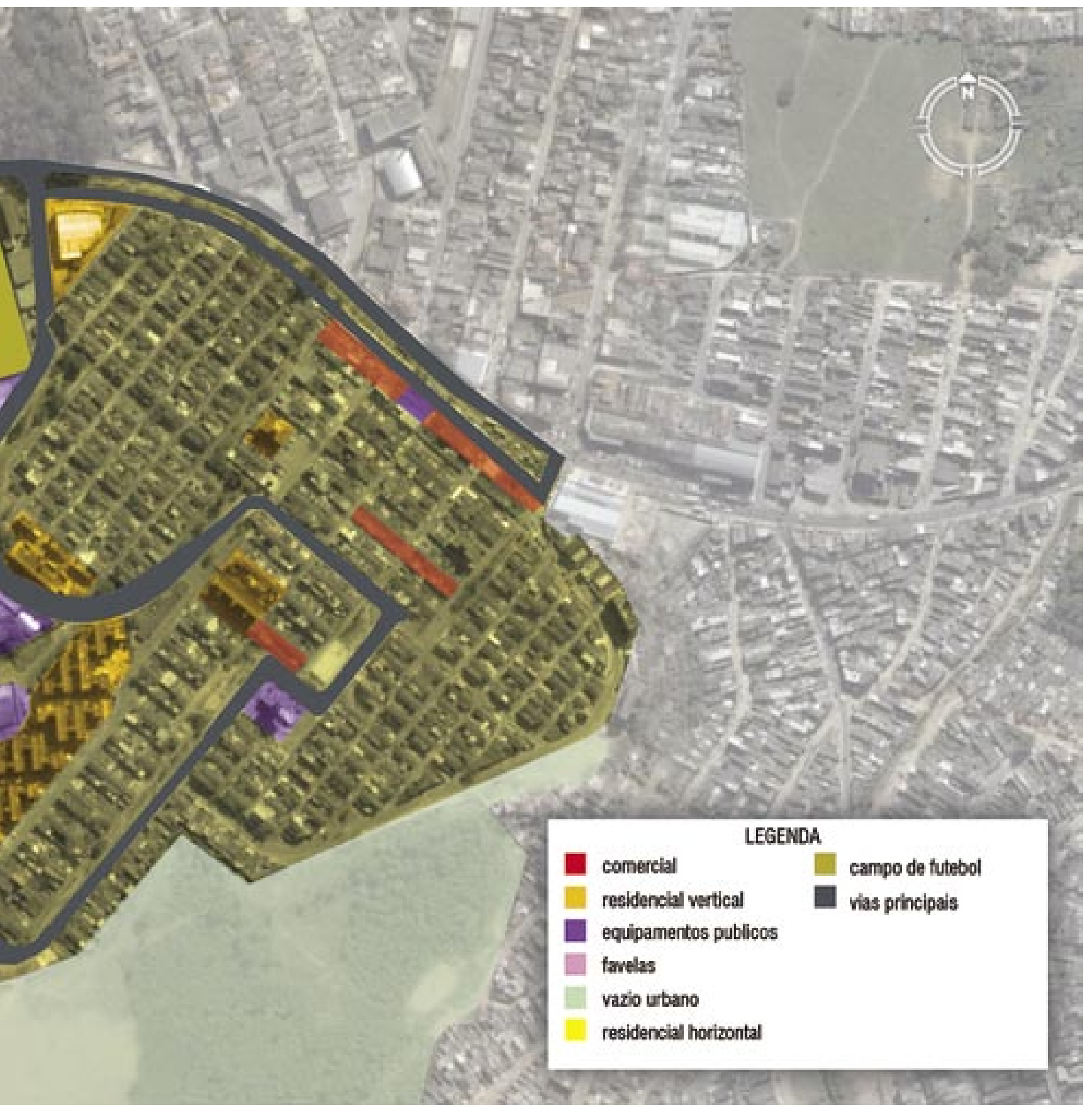




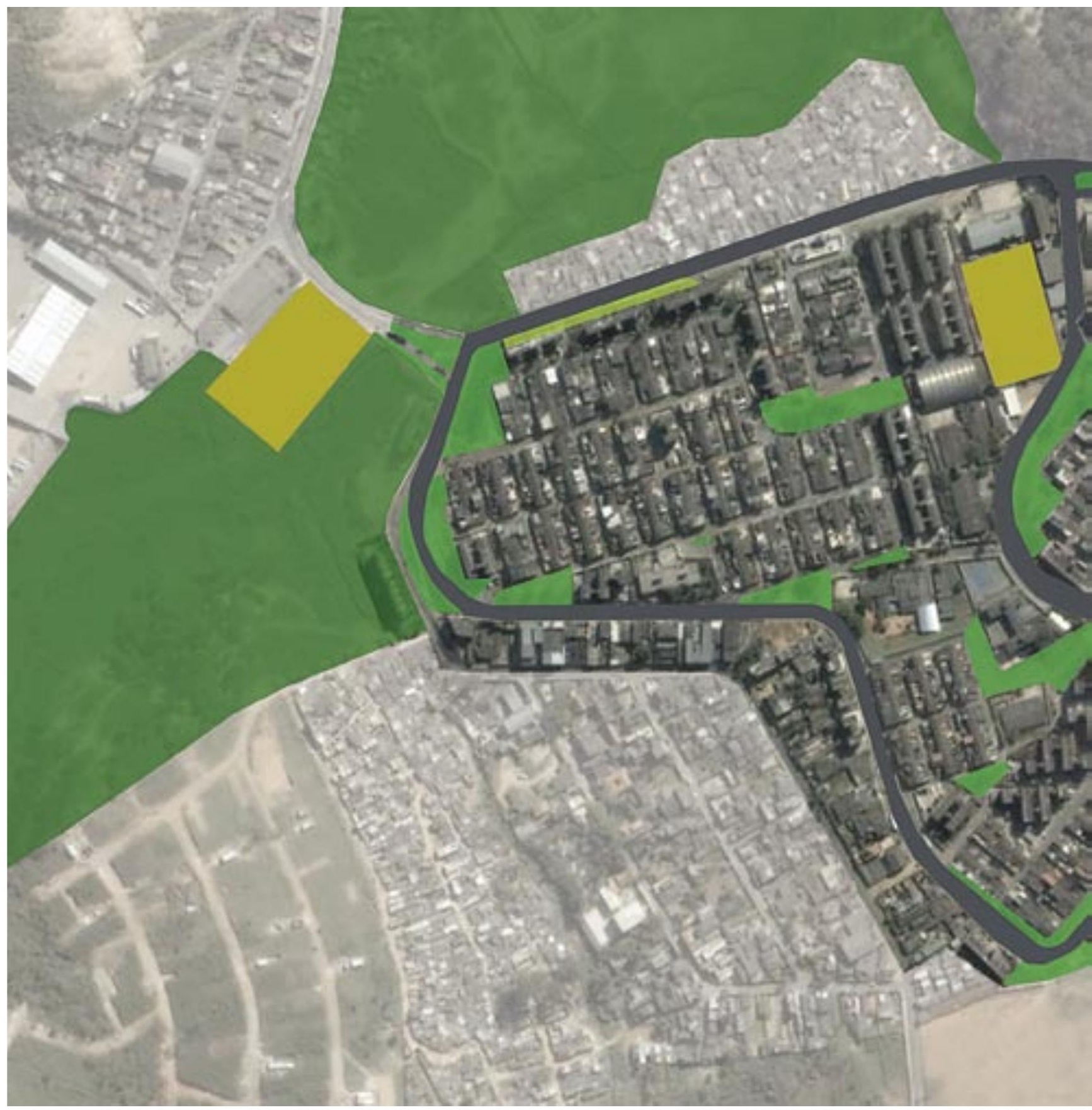




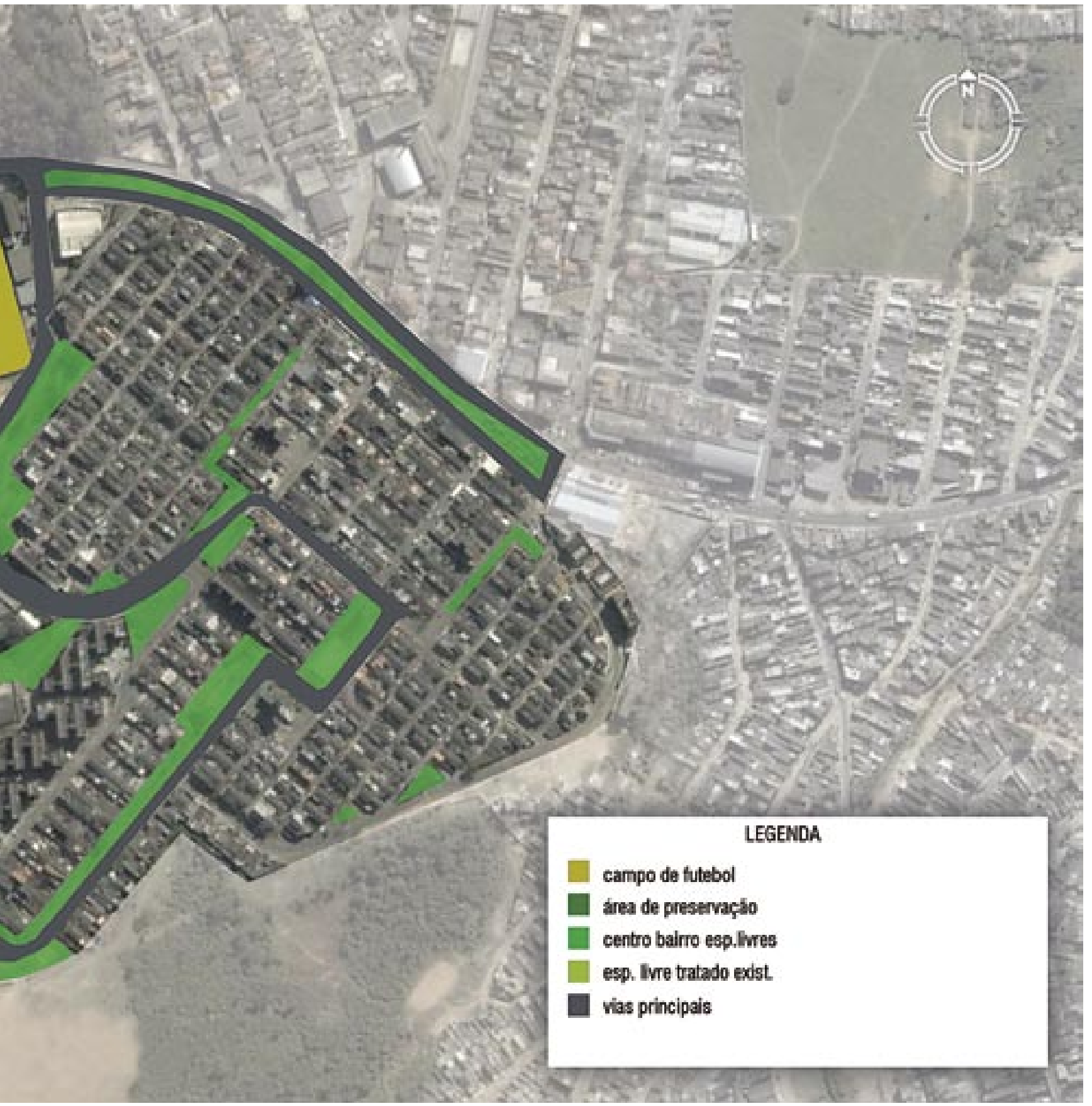



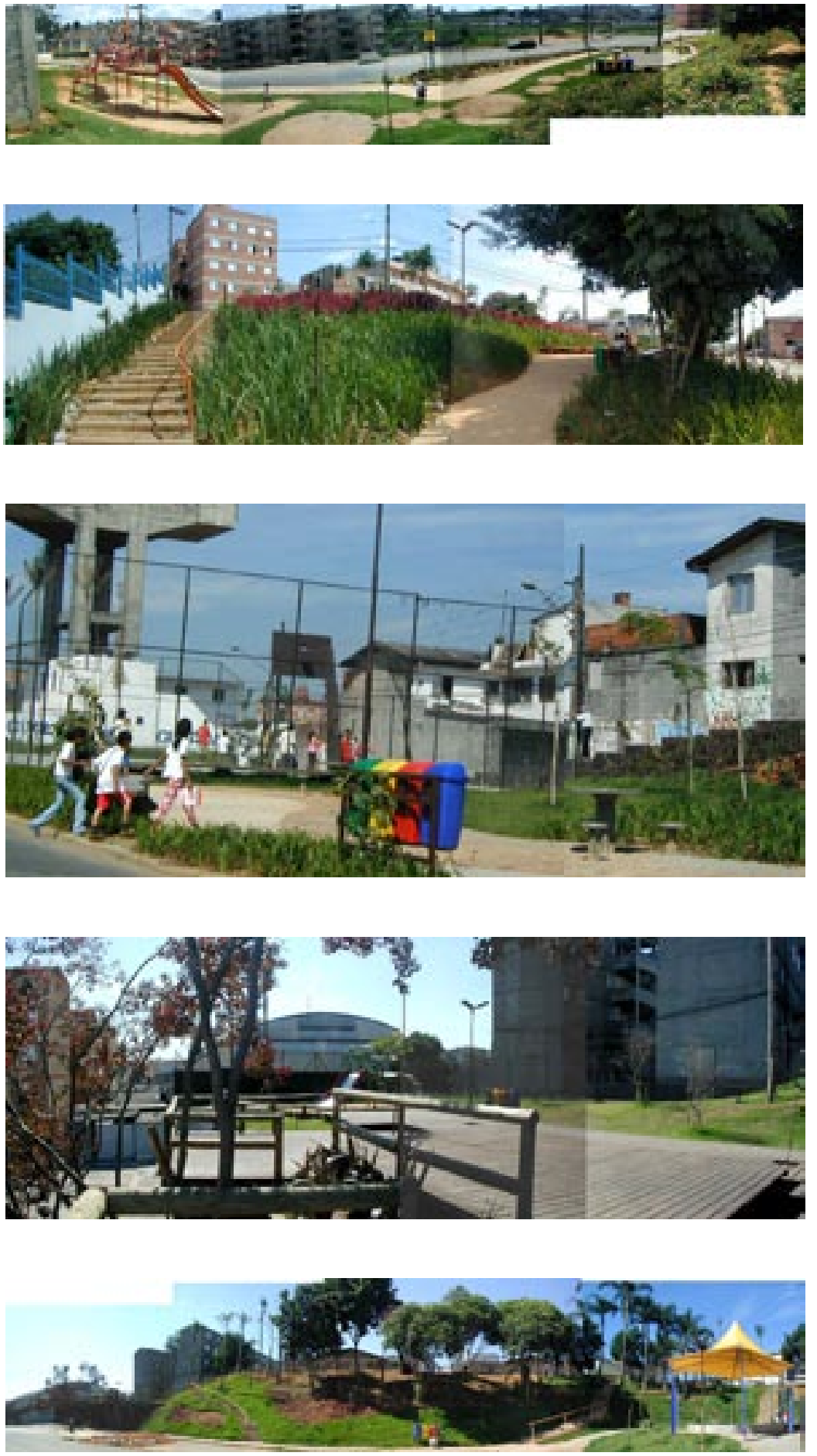

Fig. 141 a 147. (Nesta página e na seguinte). Fotos das diferentes áreas de intervenção do conjunto Bororé, com seus usos diversos.

Fotos: Lopez, 2003 

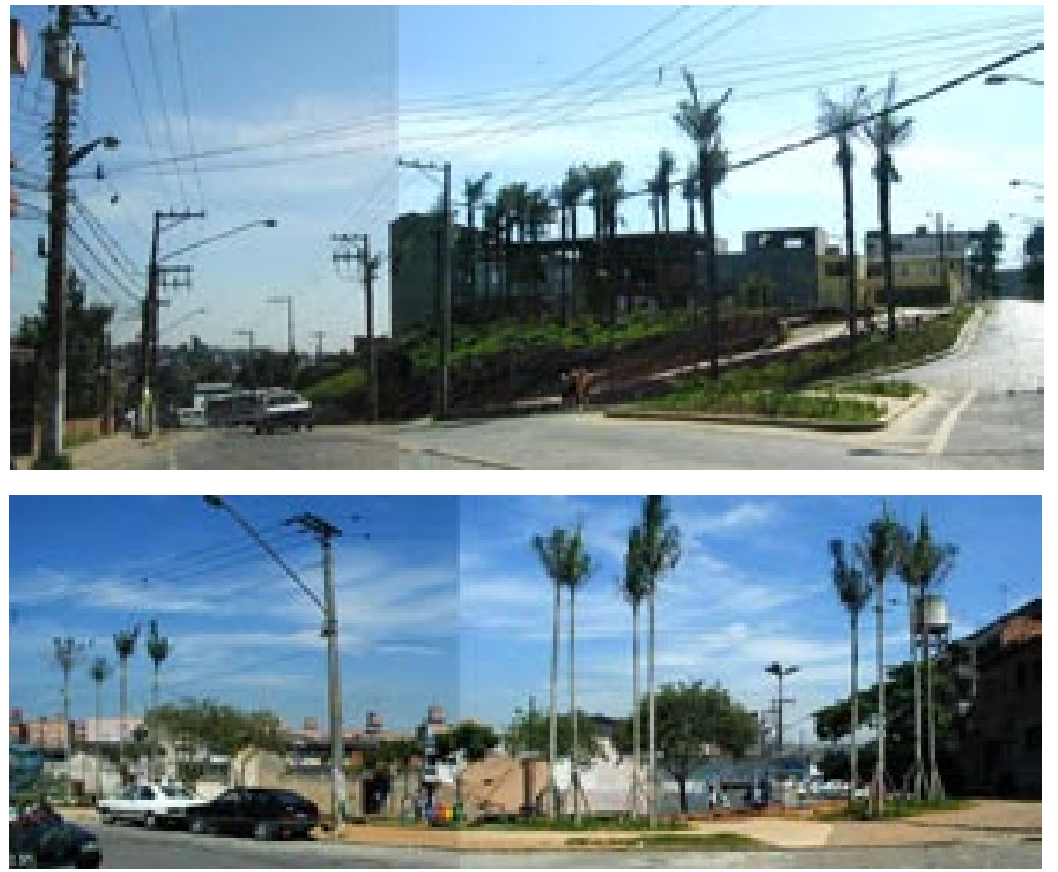

O desenho não buscou um caráter monumental desses espaços, ao contrário, com um traçado pouco pretensioso e com a utilização de materiais econômicos, estabeleceu a sucessão de pequenas praças que no entendimento do conjunto como um todo formam um sub-sistema de espaços livres do Grajaú, que se revelou pertinente a flexibilidade dos espaços, tornando dinâmico o sistema de ações da comunidade sobre as áreas; além de servir como elemento referencial principal na paisagem.

Entender o Conjunto Bororé como um Sistema de Espaços Livres é apreender a dinâmica cotidiana de seus espaços, projetados ou não. Talvez ele não seja o melhor exemplo quanto ao planejamento e desenho desse sistema - que tantas vezes é encontrado numa cidade com as dimensões de São Paulo, formado por intervenções em cima de intervenções, que vão deixando aos poucos suas marcas na cidade ou simplesmente, ao acaso, pela somatória de planos e reformas, mas certamente 
é um bom exemplo de prática da vida ativa na periferia, com todas as suas formas e apropriações de seus espaços livres.

Se estamos considerando aqui o Sistema de Espaços Livres não apenas como um conjunto de áreas verdes , mas como uma estrutura de espaços livres de edificação que interagem, estabelecendo relações e que abarca todos os espaços abertos, podemos entender que essas pequenas intervenções do Programa Centros de Bairro transformaram a dinâmica da vida das pessoas que vivem neste conjunto da $\mathrm{COHAB}$ e que interagem entre si, constituindo um sistema também dinâmico com espaços voltados à esfera pública, que se interligam enquanto sistema à todas as ruas do conjunto ${ }^{25}$; às principais avenidas da região da Capela do Socorro, algumas com canteiros centrais, outras não, algumas tratadas e equipadas com aparelhos de ginástica como é o caso da Av. Robert Kennedy ou apenas com calçadas mal cuidadas, mas que continuam sendo elementos do traçado urbano não somente de passagem, mas também abrigam as mais variadas atividade ${ }^{26}$; aos quintais abertos dos lotes de toda a trama urbana da região e da cidade, muitas vezes totalmente impermeabilizados, mas que vão se interligando e interagindo com outras praças, parques, APA's e a todos os resquícios de espaços abertos, públicos e privados, formando um sistemas de espaços livres, não ideal, que não foi especificamente planejado e que como tantos outros sub-sistemas da cidade foi ocorrendo ao acaso e que as intervenções geradas pelo Programa Centros de Bairro, apesar das muitas críticas pelo desenho, formas de implantação e imprecisões de projeto, foi capaz de gerar transformações em toda esta comunidade, aumentando a autoestima e cidadania da pessoas frequentadoras destes espaços, tornando-os ricos enquanto formas de vida urbana e apropriação pública.
${ }^{25}$ que como verificamos em outros capítulos, representam um papel tão importante como espaços de convívio e convívio principalmente na periferia ${ }^{26}$ como a venda dos mais diferentes produtos em camelôs que nelas se instalam como nos "centros de bairro" de alguns trechos da Av. Belmira Marim. 


\section{A s dem a is praças d a reg i ão}

ipanema $\mathrm{x}$ lagos

Muito diferente da apropriação ocorrida no conjunto Bororé, a praça da Avenida Ipanema com a Rua dos Lagos é quase vazia. Localizada na Vila Friburgo, no Socorro, ela acompanha por quase $1 \mathrm{~km}$ de extensão o córrego Julião, um dos contribuintes da Represa Guarapiranga, desde sua foz por bairro adentro.
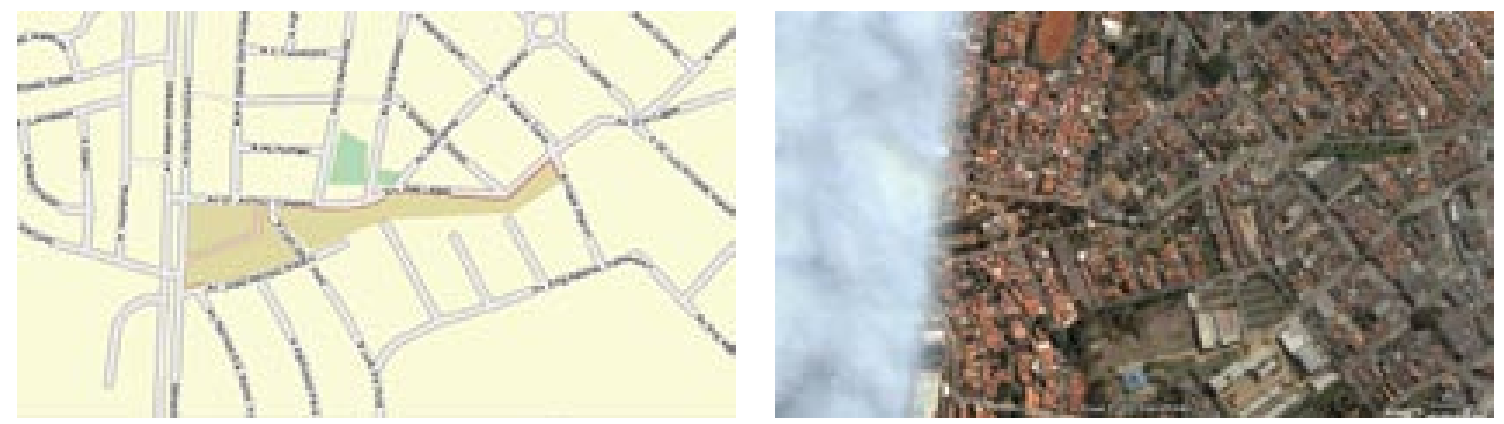

Fig. 148 e 149. À esquerda croqui de localização da área. À direita foto aérea da praça já implantada.
Majoritariamente ocupada pela população de média e alta renda, esta área teve seu desenvolvimento marcado pelo interesse da especulação imobiliária, já no inicio do século $X X$, na formação de loteamentos de casas de alto padrão, chácaras de recreio, clubes de campo e clubes náuticos no entorno da Represa Guarapiranga, vislumbrando um alto potencial de lazer para toda a região.

A área é longa e estreita; e possui uma "interessante" implantação ao longo do Córrego Julião interligando pequenas áreas livres existentes por meio de passeios arborizados, principalmente com o plantio de frutíferas, implantados em restos de áreas provenientes dos parcelamentos das glebas e do traçado do sistema viário. Seu entorno é basicamente residencial, salvo a existência de uma sede dos escoteiros na primeira quadra de implantação da praça, na esquina com a 
Avenida Robert Kennedy e de um Centro Desportivo Municipal (CDM) nos quadrantes finais.

Essa situação, juntamente com a possibilidade de lazer privado, fruto dos tamanhos dos lotes e do acesso a possíveis clubes particulares, faz da praça um local pouco movimentado.

Porém, a indicação dessa área pelo então subprefeito, teve por traz a tentativa de resolução de um problema social. Nesta mesma área, ocupando os quadrantes centrais da praça e fazendo divisa com um CDM, mais precisamente no que seria o leito carroçável de um trecho da Avenida dos Lagos, houve uma invasão ainda na fase de implantação da avenida e a ocupação por uma favela no local. A tentativa era de desapropriação do local com a retirada das famílias e sua recolocação em conjuntos habitacionais da região, para a restituição do sistema viário e melhor interligação entre as áreas da futura praça com o CDM; fato que não se consumou.

A implantação de um sistema de objetos com a intenção de tornar a área um espaço público voltado para o convívio e o lazer, não foi forte suficiente para resolver esse grave problema social de interação entre setores com extratos de renda tão diferentes.

Os canteiros estão tomados em alguns trechos pelo mato e onde a vegetação herbácea e arbustiva implantada é menos resistente. Os brinquedos, apesar do uso menos intenso, são mal mantidos e apresentam danos que podem machucar seriamente as crianças que os estiverem utilizando.

Assim, certa ociosidade deste espaço livre leva talvez a uma imagem de que ele não é necessário. O descaso do poder público com a manutenção da área enfraquece a vida pública deste local e contribui para diminuir o valor dado a ele pela população, que o vê como um local favorável para ladrões e estupradores que podem se esconder atrás das moitas formadas pelo mato alto.

Porém, essa área tem uma outra importância que talvez
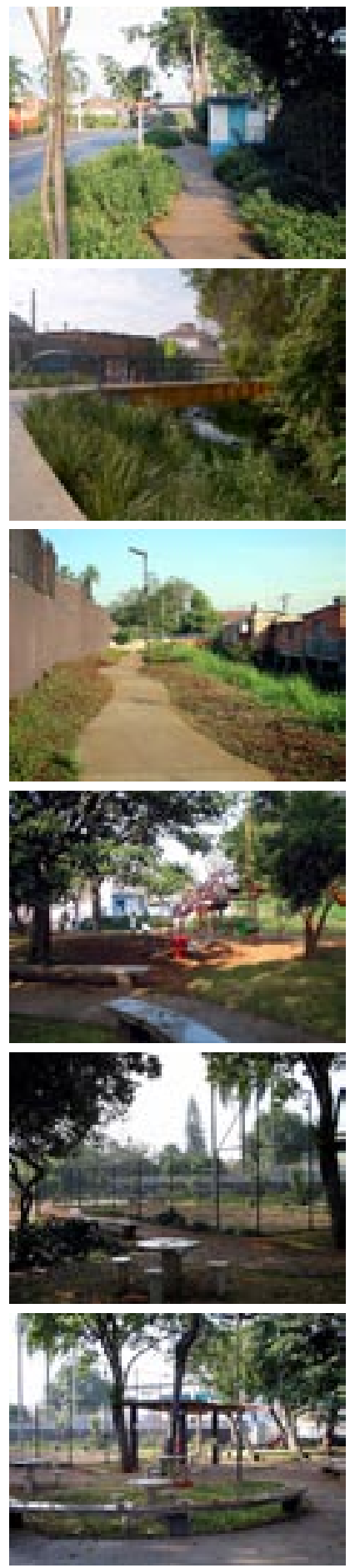

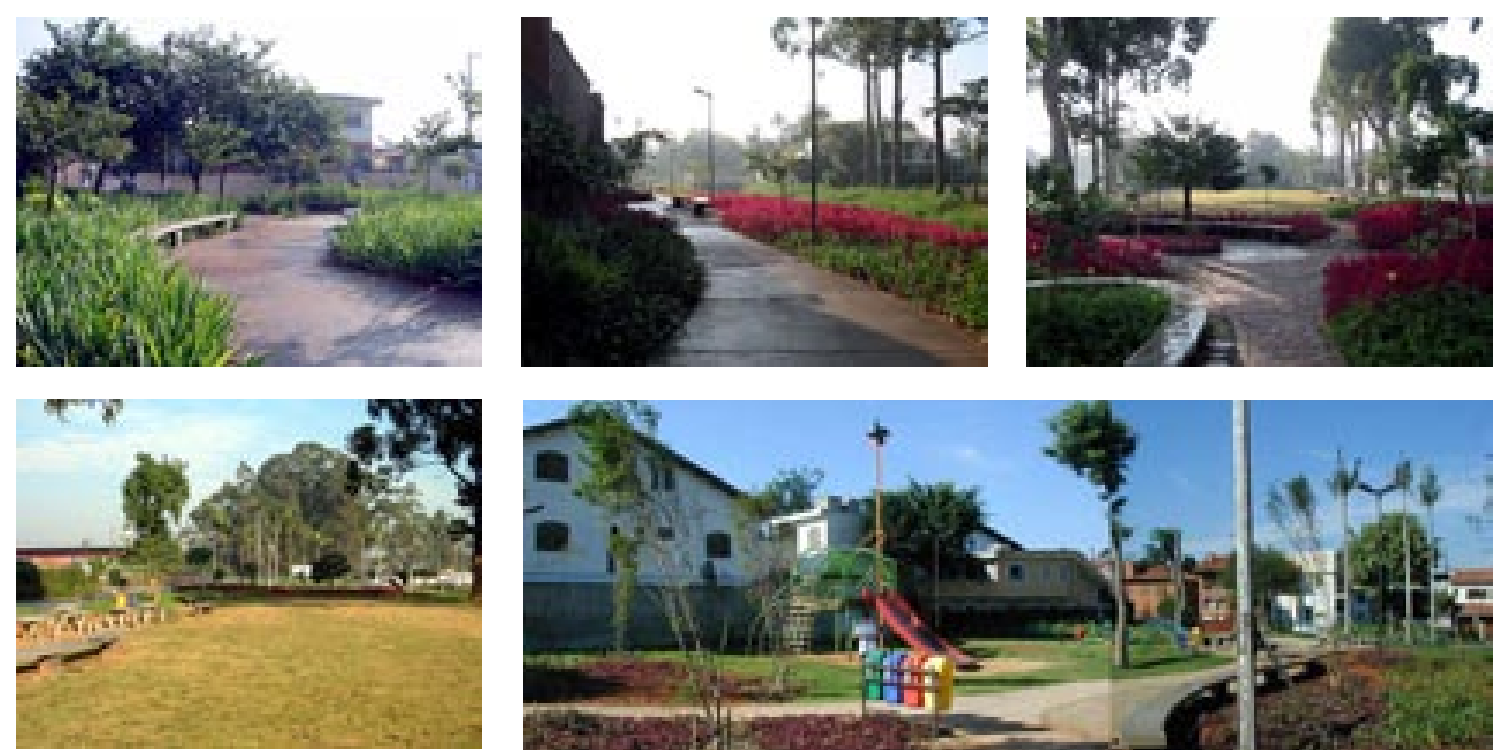

Fig. 150 a 160. (nesta página e na anterior). Um percurso pelos diferentes setores da praça. Foto: Lopez, 2003 não tenha sido vislumbrada pela coordenação do programa, que a torna muito especifica frente a qualquer outra praça, que é a possível formação de um corredor verde com a interligação desses pequenos espaços livres, alguns com a vegetação de porte arbóreo já formada, e outros com o plantio de espécies como o os Ipês Amarelos e Rosas, Paineiras, Ingás, Eritrinas, Sibipirunas, Bauhinias, e Seaforcias, por corredores de frutíferas como Jabuticabeiras, Pitangueiras, Amoreiras e Goiabeiras, com a faixa lindeira à Represa Guarapiranga; permitindo uma tentativa de recomposição do ecossistema local junto com a ampliação da área de circulação da ave-fauna.

\section{várzea do córrego são josé}

A área da Várzea do Córrego São José não foi concluída por problemas na aprovação do projeto junto a órgãos ambientais estaduais, mesmo se tratando da implantação de um parque de conservação ambiental, da vegetação arbórea e arbustiva existente e da formação de novos maciços arbóreos com o 
plantio de espécies nativas repondo áreas de antiga mata ciliar e várzea, interligando os "spots" de vegetação remanescente, com área aproximada de $140.000 \mathrm{~m}^{2}$ junto à Foz do Córrego São José - outro afluente da Represa Guarapiranga.

O projeto visava ainda a criação de uma área destinada ao convívio e recreação junto ao bairro, numa faixa lindeira à avenida de acesso com a implantação de quadras, pista de bicicross e áreas de estar.

Apesar de não ter sido realizada, esta área consta aqui como parte integrante do programa e para uma efetiva análise do possível sistema de espaços livres "proposto".

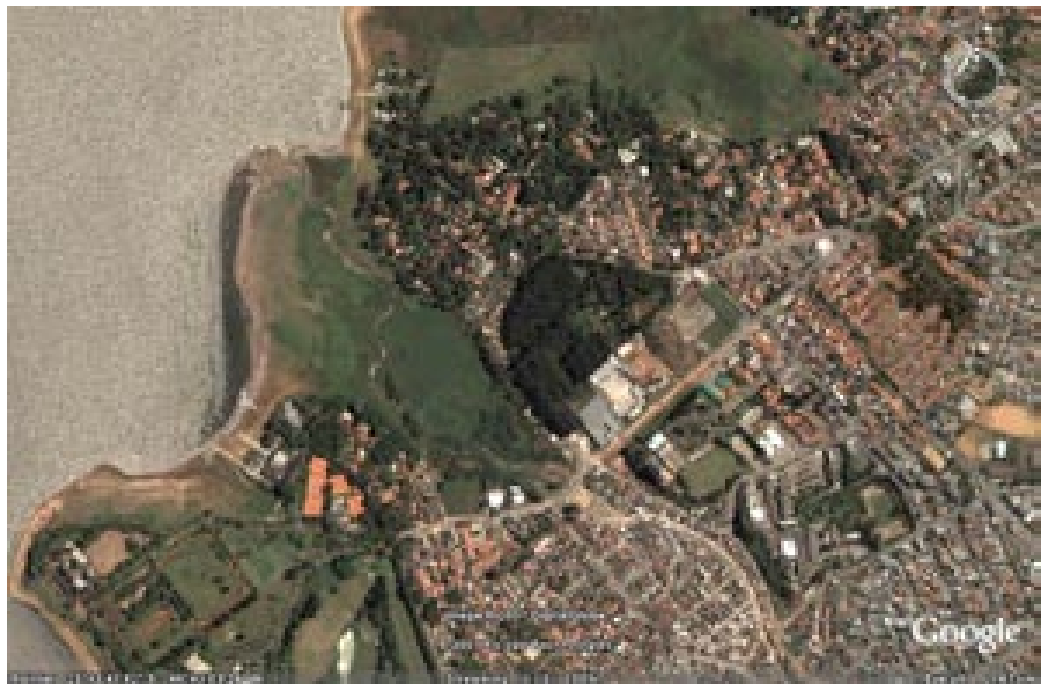

Fig. 161. Foto aérea do local de intervenção proposta

Já na Praça do Trabalhador, área de aproximadamente $25.0000 \mathrm{~m}^{2}$, hoje pertencente à subprefeitura de Parelheiros, também na zona sul, houve uma configuração e apropriação do espaço bem diferente. Talvez, junto com o Bororé, ela seja uma das áreas que mais se desenvolveu com a expectativa inicial do programa.

Constituída por uma "rotatória", na realidade uma grande 
${ }^{27}$ neste local durante as obras foram encontrados junto ao entulho existente dois corpos de cidadãos não-identificados. ilha de um resto do traçado viário, que se encontrava abandonada pelo poder publico servindo como local de bota-fora e "desova de corpos"27. Esta área se localiza no extremo sul da cidade, junto à Avenida Senador Teotônio Vilela, servindo de acesso a Parelheiros e a Colônia.

Fig. 162. (ao lado) Croqui de localização da praça

Fig. 163 e 164 (abaixo). Fotos do local antes da intervenção. Fonte: Arquivo da EMURB, 2001
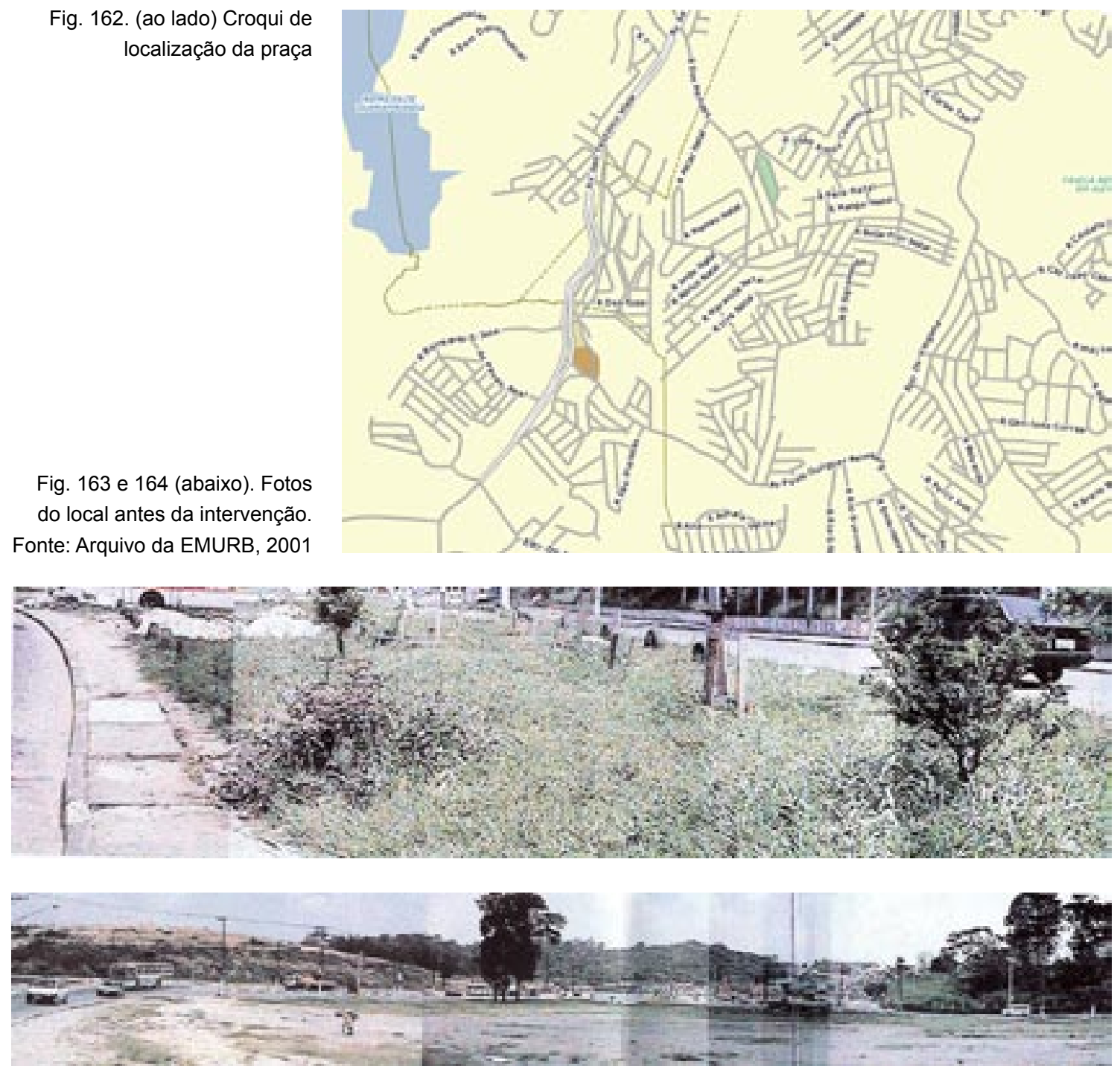
Configurada em 2002, ano de sua implantação e entrega à população, por um uso nada definido de seu entorno, contava com áreas livres do estoque do município e particulares que ocupavam a maior parte das divisas da praça. Uma outra parte já se encontrava ocupada por uma invasão irregular que não possuía a mínima infra-estrutura básica, inclusive para seu acesso.

A intervenção teve a implantação dos mesmos tipos de equipamentos antes descritos. Com a criação de 3 quadras, sendo uma poliesportiva e 2 de areia (as quadras de areia foram implantadas com o objetivo de sanar as disputas de ocupação das quadras poliesportivas - maiores, entre adolescentes e adultos e as crianças, que sempre saiam perdendo); pista de Cooper com a implantação de alguns aparelhos de ginástica; pista de skate - a primeira a ser implantada pelo programa e pelo intenso uso de jovens e crianças, acabou sendo uma reinvidicação da própria prefeita para todas as áreas; palco para pequenas apresentações; áreas de convívio com pergolados; playground, além de um telecentro e um centro de capacitação do cidadão.

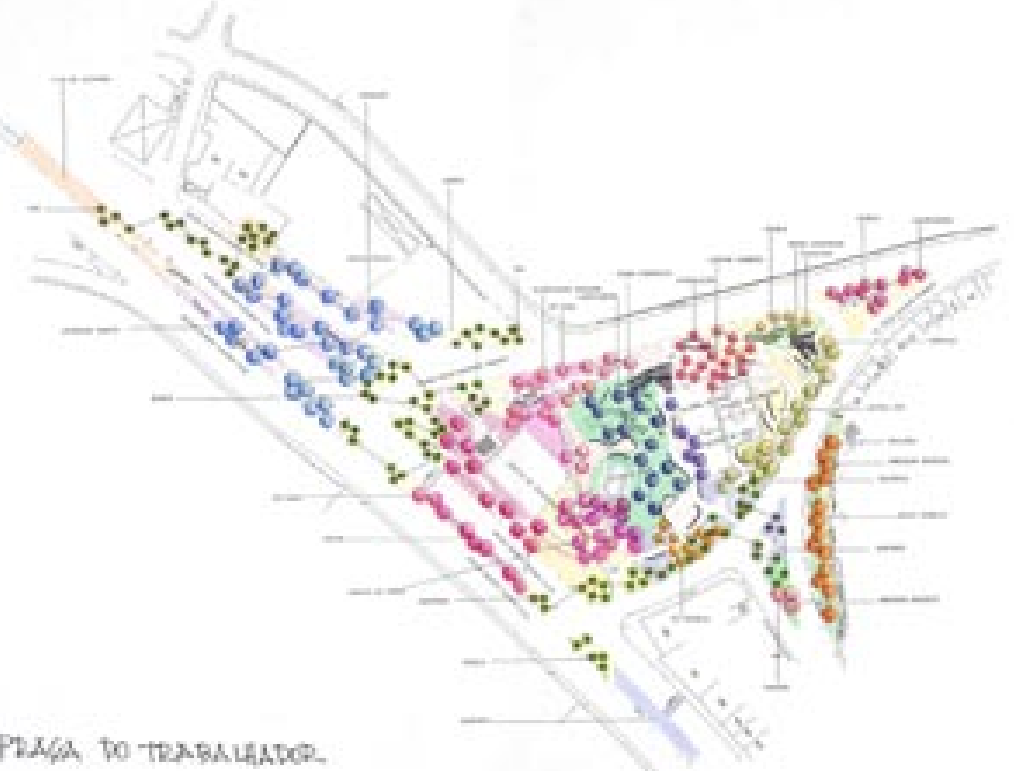

Fig. 165. Planta de Implantação da praça 
Fig. 166. (ao lado) Maquete eletrônica apresentada à comunidade

Fig. 167 e 168. (abaixo) Fotos do local depois da intervenção. Fonte: Lopez, 2003
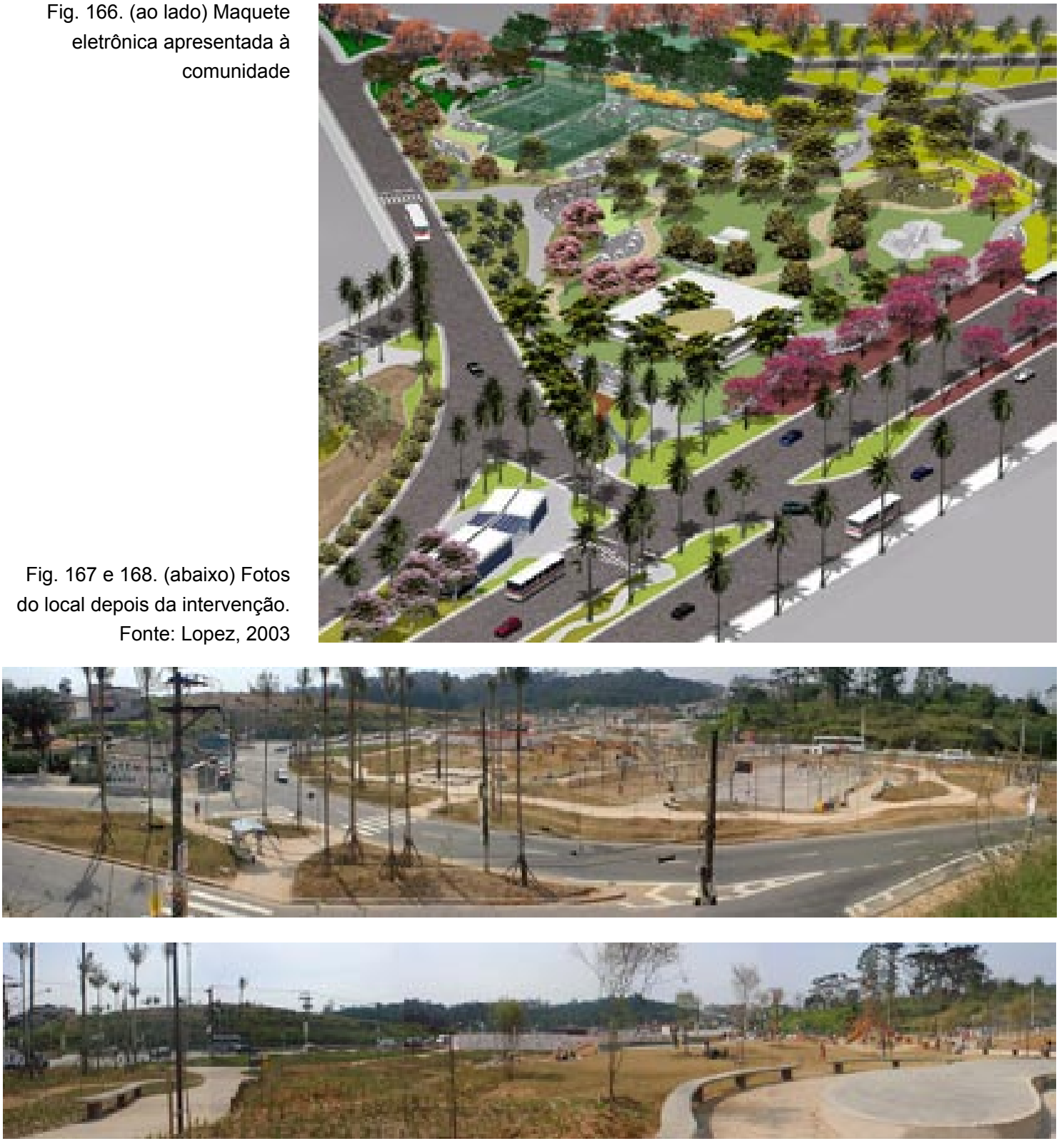

A princípio houve resistência da comunidade local, principalmente da ocupação irregular, para a implantação da praça, que tinham como justificativa "não precisarem de praças e sim de escolas, postos da guarda municipal e de saúde, 
rede de esgotos,..." entre tantas outras contidas no discurso da população que ocupa áreas de invasão, principalmente em áreas com risco de desmoronamentos como era esse o caso.

Mas, depois da conclusão das obras, o resultado da apropriação foi bem diferente. Talvez em função da escassez de espaços livres públicos destinados ao lazer, sendo quase nula na região, inclusive de CDMs; por se caracterizar pela concentração de população com renda muito baixa - a maioria inferior a um salário mínimo por mês; esta área de intervenção teve uma repercussão de uso e apropriação do espaço livre público muito maior do que o esperado.

A praça é intensamente utilizada, chegaram a ser contadas no pico de uso num domingo à tarde, logo após a entrega da praça, quase 3.000 pessoas no local. Nessa época a SPTRANS teve que aumentar o número de carros (ônibus ou vans) das linhas que passavam pela praça, para suprir a procura por este transporte até o local. Alguns brinquedos de ferro que haviam sido instalados, três meses após a sua liberação para o uso, tiveram que ser substituídos pois estavam gastos. Crianças faziam fila para utilizá-los.

Em novembro de 2003 numa outra contagem, havia 300 pessoas num fim de tarde de quinta-feira; revelando uma vida pública bastante intensa no espaço livre de um bairro pobre. (Fig. 169 a 174)

Hoje, quase cinco anos após a entrega das obras, a vida ativa no cotidiano da praça continua rica. Numa contagem realizada em fevereiro de 2007, havia 230 pessoas utilizando a praça num sábado pela manhã. Mas, o mais impressionante foi verificar a transformação, que já tinha se manifestado no final de 2002, ocorrida no entorno. Da pobre rotatória, abandonada ao mato e ao lixo, não sobrou nada. Além da Praça, instalaram-se no local um supermercado de uma grande rede num dos terrenos particulares, e um grande terminal de ônibus num dos terrenos do município. A praça esta mal mantida, mas os equipamentos
Fig. 169 a 174. (nesta página e na seguinte). Fotos dos diferentes usos da praça.

Fotos: Lopez, 2003
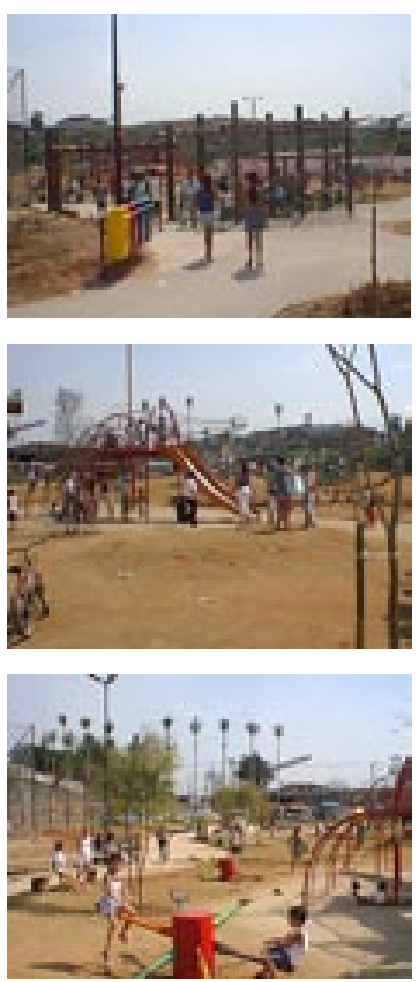

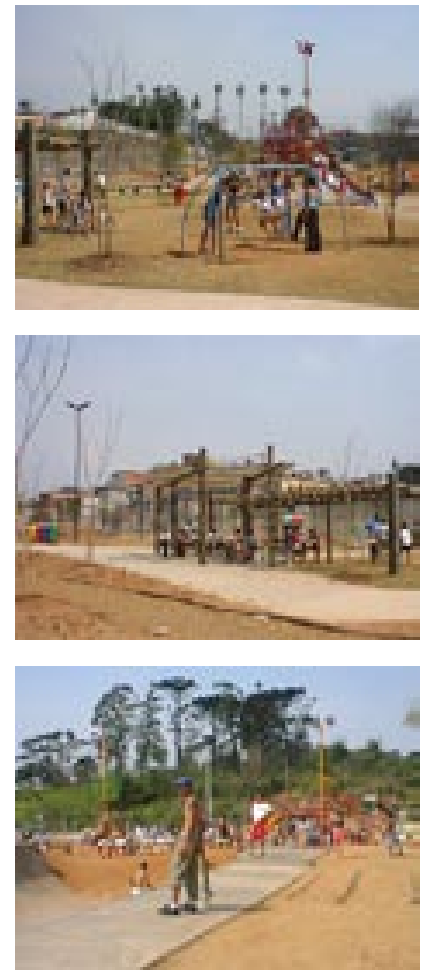

continuam sendo utilizados intensamente pela população. Havia um grupo de adultos utilizando a quadra poliesportiva - que já apresenta seu alambrado bem deteriorado; outros grupos de crianças, de diferentes faixas etárias dividiam o espaço das quadras de areia; os pequeninos brincavam no playground sobre os olhares atentos dos pais sentados nos bancos e uma mulher vendia cachorro quente sob a sombra dos pergolados entre 0 vai-e-vem de pedestres com destino ao terminal, enquanto um grupo de idosos permanecia sentado num dos bancos sob o mirante dos outros pergolados.

Assim, o Programa Centros de Bairro pode implantar espaços livres públicos mais dignos e democráticos para a expressão da cidadania, ou "criar ambiências urbanas de vizinhança" como diria o Arqt $^{\circ}$ Sergio Marin. Alguns tiveram mais erros do que acertos, mas serviram de base para transformar o olhar de determinados setores do poder público para a cidade. Outros, como observa Queiroga, na expressão de Umberto Eco, trataram-se de "obras abertas, menos por intenção prévia, e mais pela forma intensa e espontânea de uso da população, por vezes ilegais realizados no território dos pobres. O governo não cobra legalidade e formalidade se ele mesmo não oferece condições para isto". Em outros casos, teve que satisfazer apenas as imposições políticas; o fato é que bem ou mal ocorreram requalificações sociais, culturais e ambientais - no sentido mais amplo da palavra - funcionando como um sistema de melhorias urbanas na periferia da cidade de São Paulo, capaz de recategorizar estas áreas e mudar o olhar do cidadão sobre a sua cidade. 


\section{A inclusão de processos p a r t i c i p a t i o s}

O conceito de participação abrange um amplo leque de classificações, desde um processo simplista de consulta à população, podendo passar por etapas de discussão de projeto e por um processo de auto-gestão, onde o papel do arquiteto acaba se tornando secundário, conformando diferentes graus de envolvimentos com a comunidade.

As experiências mais conhecidas no Brasil, relativas a processos participativos, no âmbito circunscrito de nosso objeto de estudo, referem-se em sua maioria, a atividades ligadas a projetos e construções de moradias populares, muitas das quais realizadas através de mutirões. O que se verifica, normalmente, é que uma vez concluídas a s obras, cada participante retorna aos seus afazeres pessoais, deixando de lado a convivência solidária ocorrida durante todo o processo. No caso dos espaços livres, devido ao caráter intrínseco de seu uso socializado, existe uma possibilidade maior de ocorrer um processo coletivo continuado e mais duradouro.

Um equívoco recorrente nos processos participativos é a crença em uma participação neutra, com objetivos genericamente amplos e desvinculada das determinações político-sociais. As ações humanas possuem uma intencionalidade, um desejo, ou seja, um conjunto de valores a conquistar ou a defender mesmo que, muitas vezes, não se apresentem com clareza para seus agentes.

É importante que o exercício pedagógico do processo participativo, procure criar condições não somente para um terreno do consenso, mas que possibilite que as decisões finais e coletivas surjam pela exposição e discussão exaustivas de diferentes pontos de vista. Que considerem também como parte do debate, as situações de conflito, cuidando para que eles não resultem em processos desestruturadores do conjunto. 
Assim, nos referimos a processos participativos na elaboração de projetos de espaços públicos, como processos que inter-relacionam a atividade do arquiteto e de outros profissionais que estudam e projetam esses espaços, com as pessoas que utilizaram esses lugares, seus sonhos e seus desejos. $E$ como nos relata o arquiteto Raul Pereira, "é uma construção de conhecimento que se processa de forma coletiva, não implicando na anulação dos profissionais envolvidos, senão no seu enriquecimento, assim como no dos outros participantes".

É notável o esforço de algumas comunidades pobres de construir as suas praças, onde a idealização básica é construir uma praça ajardinada, arborizada e com equipamentos para a recreação infantil e para os esportes. Algumas vezes eles contam com algum tipo de auxílio do poder público que disponibiliza algum recurso técnico ou material. Mas os processos participativos podem se realizar a partir de ações do Estado para este fim. A produção de praças pode se constituir em oportunidades de envolver a população em processos participativos de diferentes níveis, desde a elaboração do programa da praça, passando pela discussão do projeto e a participação na execução.

Algumas experiências realizadas por Pereira, na Prefeitura de Osasco na década de 80, com a implantação de espaços públicos no município, demonstram que muitas das praças bem conservadas, são justamente aquelas onde ocorreu alguma forma de envolvimento dos moradores. Em Santo André, a implantação de praças por processos e mutirão também tiveram uma maior aceitação e apropriação desses espaços pela comunidade.

Já o Programa Centros de Bairro não encontrou canais abertos do poder público com a população. As subprefeituras por suavez possuíam uma relação mais de atendimentoà comunidade que de discussões e decisões conjuntas e, implantar esse novo tipo de relação se tornou inviável no contexto do programa e seu tempo de execução. O processo de participação da comunidade 
vislumbra todo um intercâmbio entre a comunidade e o poder público, que por sua vez deve estar aberto e estruturado para receber todas essas informações; não basta simplesmente fazerse reuniões para "escutar" a comunidade e a partir daí dizer que se tratou de um processo participativo. O Programa Centros de Bairro não conseguiu muito além disso.

Salvo em algumas áreas iniciais do lote 1 e 2 que tiveram uma dinâmica inicial do que estamos aqui chamando de processos participativos, com reuniões iniciais na fase de préprojeto e depois reuniões durante todas as fases de projeto. Esse fato se deu nas Subprefituras da Capela do Socorro e da Penha, em áreas que o subprefeito tinha um engajamento maior com os centros comunitários dos respectivos bairros de intervenção. Nestas áreas pode-se notar um envolvimento maior da população com a intervenção, inclusive no pós obras com a implantação de atividades ao ar livre nestes locais como feiras de artesanato, noites musicais, entre outras.

Mas, de modo geral, as ações propostas não envolveram grandes polêmicas ou conflitos, mas é provável que se tivessem tido um envolvimento maior das comunidades, as intervenções teriam sido mais precisas no atendimento das necessidades de cada local, gerando uma repercussão e um engajamento maior na gestão das praças.
Fig. 175 e 176. Fotos da apresentação do projeto da Praça do Largo do Araribá à comunidade, que já havia sido discutido com seus representantes.

Fonte: Arquivo Emurb, 2001
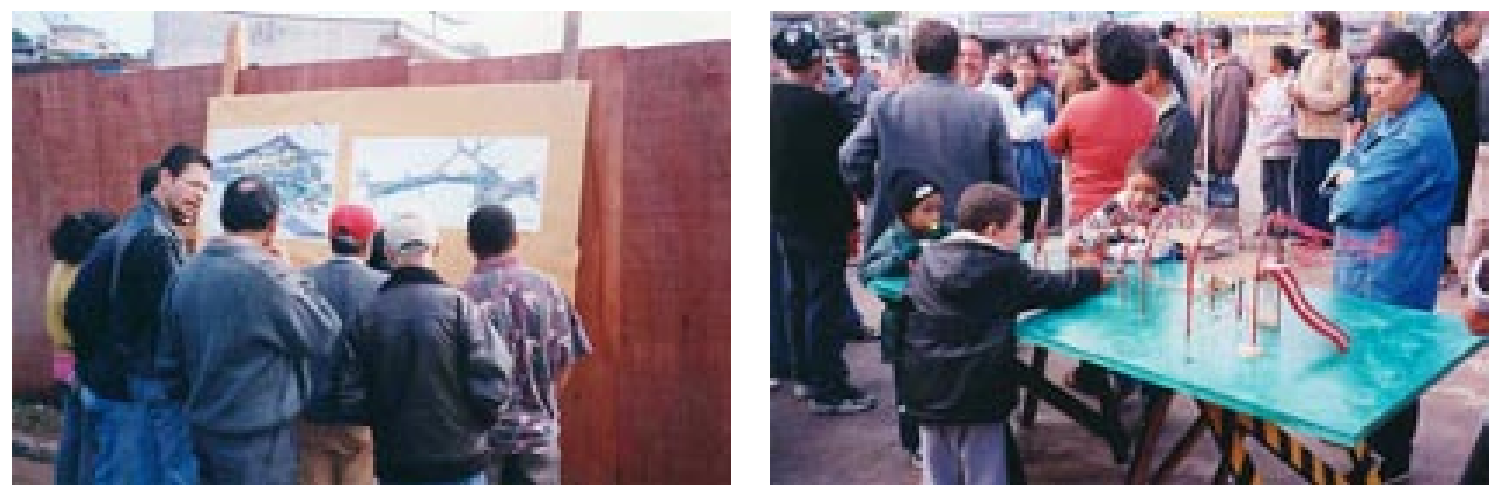
Assim, pode-se dizer que a implantação de espaços livres deve estar vinculada a um processo mais amplo, no qual se inclua a participação dos moradores, para que haja oportunidade deles se sentirem reconhecidos como agentes integrantes desses espaços. Só assim poderá existir um reconhecido e valioso programa de gestão, organizado e gerido pelos próprios usuários dessas áreas.

A i m portância d a a r borização do siste m a $v i$ ário para a forma ção do Sistema de Espaços Livres

Finalmente, não poderíamos deixar de destacar aqui a importância do sistema viário e de sua arborização para a formação do Sistema de Espaços Livres para a cidade e a sua interconectividade com os demais espaços livres.

A vegetação possui um papel importante como elemento estruturante e de percepção da paisagem, diferenciando os espaços construídos dos espaços livres. Através de suas formas cores e texturas, pode funcionar como elemento estético para reforçar ou induzir percursos pela cidade, criando espaços de convívio, estar e contemplação..., além de também ser utilizada como elemento cenográfico, capaz e criar identidades e relações de vínculo com os moradores de cada região, e contribuir de maneira significativa para a melhoria do conforto ambiental e da qualidade de vida da população.

"A arborização no espaço da malha urbana, satisfaz em primeira instância, as necessidades estéticas e de conforto climático. A preservação, a conservação e a restauração de estrato arbóreo do ecossistema local, seja ele natural ou antrópico, deve ser considerado como um valor intrínseco de 
qualidade e vida e de parte integrante do patrimônio ambiental e paisagístico das cidades" (CHACEL, 2004).

Dessa forma, o uso da vegetação não pode ser visto apenas como um acessório. A alteração contínua de sua forma, cor e crescimento cria uma referência temporal, revelando sua história e imprimindo sua memória na geografia da cidade.

O crescimento das árvores estabelece ainda uma relação dinâmica de escala que, em contraposição com os espaços edificados, acaba criando um movimento também dinâmico com as nossas vidas, através de um percurso do cotidiano.

"As árvores das vias públicas, ao mesmo tempo em que constituem um elemento importante da paisagem urbana, possuem um significado importante para o cidadão, proprietário ou usuário do imóvel, em frente ao qual está plantada. Com a perda ou a redução sucessiva dos quintais, a árvore da calçada passa a representar uma figura simbólica, como extensão de seu lote, e de transição, entre o espaço público e privado." (PEREIRA, 2006).

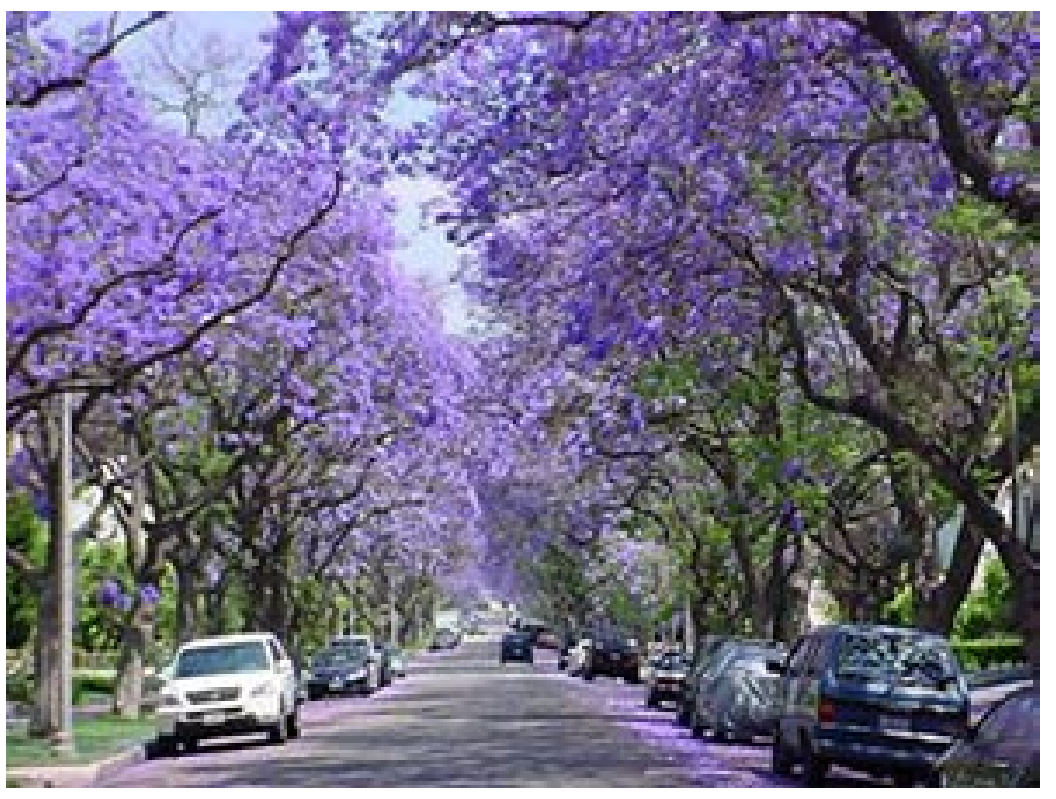

Fig. 177. Foto de arborização urbana de Buenos Aires - Argentina - com a utilização de Jacarandás Mimosos. 
A forma de ocupação desordenada da cidade, determinada muitas vezes pela especulação imobiliária, pelo poder público ou por loteamentos clandestinos, onde é priorizada a circulação de veículos em detrimento do pedestre, deixando em média um espaço para calçada de $1,50 \mathrm{~m}$, só vem ressaltar a importância da arborização das vias públicas.

Em estudo realizado por Roberto Vignola, em 2005, para o município de São Paulo, baseado em dados oficiais, se fosse realizada a implantação de arborização do sistema viário existente com um espaçamento médio entre os indivíduos de $7 \mathrm{~m}$, considerando ruas pavimentadas e não pavimentadas, teríamos uma biomassa com $105 \mathrm{~km}^{2}$. Hoje, somando as áreas das marginais do Rio Pinheiros e Tietê, dos parques municipais e estaduais, praças e canteiros temos um total de $27,7 \mathrm{~km}^{2}$, ou seja, nem $30 \%$ da área arborizada hipoteticamente estimada. ${ }^{28}$

Os bairros periféricos são os que mais necessitam de áreas verdes, e são justamente os que menos possuem condições de implantá-las, devido à natureza de seu traçado urbano e à densidade construtiva inadequada quanto ao uso e ocupação do solo.

Somado a essas dificuldades, existe o fato de que na história da arborização urbana das cidades brasileiras, raramente houve um projeto adequado e planejado como aconteceu em algumas cidades européias. Na prática, um plano de arborização urbana para. São Paulo viria suprir, como medida de socorro, o déficit na distribuição sistêmica e igualitária de áreas verdes na cidade, além de criar eixos de interligação entre os mais variados tipos de espaços livres públicos, possibilitando a formação de corredores verdes pela cidade e possivelmente garantindo uma melhor conservação da ave-fauna paulista.

${ }^{28} \mathrm{VIGNOLA}$, Roberto. A arborização as vias públicas e a paisagem urbana. 2005 , pág.

${ }^{29}$ O termo evapotranspiração refere-se à evaporação da água pelas folhas e solo ao redor.
Outro beneficio muito importante gerado pela vegetação está em reduzir o ganho de calor nos edifícios através da redução da temperatura ambiente pelo processo de evapotranspiração ${ }^{29}$ durante o verão. Em alguns casos, isso diminui a carga latente 
do ar condicionado, através do aumento da umidade do ar.

Nos dias quentes de verão, a árvore funciona como um sistema de resfriamento evaporativo natural, e este processo ajuda na diminuição da temperatura ambiente, o chamado "efeito oásis" (oasis effect). ${ }^{30}$

Assim, um plano de arborização deverá considerar as soluções globais e específicas de cada local; indicar as espécies adequadas para cada situação, seja ela atual ou futura.

Na seleção das espécies vegetais deverão ser consideradas as relações entre suas características do grau de crescimento e altura até a parte inferior de ramificação, e as do sistema viário (intersecções, curvaturas, acessos de veículos, acostamentos, estacionamentos e declividades).

Além dessas considerações, a seleção deverá observar as condições de clima, tipo de solo, umidade do solo e do ar, resistência aos ventos, não propensão a doenças e proliferação de insetos não desejados, mínimo de resíduos orgânicos devido à própria planta, bem como a ocorrência de raízes superficiais que prejudicariam a pavimentação.

As espécies adequadas para arborização de ruas devem possuir algumas características como mínima manutenção e condições de implantação; e graus de crescimento que permitam o sombreamento, características plásticas de volume, porte, textura, e coloração, além de exigências quanto ao controle de pragas e podas. As espécies selecionadas devem ser além de atraentes, práticas.

Após essas considerações, é importante observar que os espaços abertos para os quais pode-se caracterizar uma série de funções diversificadas para a arborização urbana, hoje, no entanto, dão lugar a deficiências que põem ser superadas como:

- permitir iluminação, ventilação e insolação natural às edificações,

- permitir perspectivas e visuais para o cenário urbano,
${ }^{30}$ Kramer and Kozlowski, 1960. Em anexo segue, como mero quadro quantitativo, o resultado de um estudo realizado junto à disciplina AUP5859 - Estúdio da Paisagem, coordenada pelo Prof. Dr. Paulo Pelegrino, realizada durante o segundo semestre de 2006, na qual os alunos elaboraram uma proposta de Infra-estrutura verde para a região do Córrego da Invernada, zona sul da cidade, próximo ao aeroporto de Congonhas; na qual há uma preocupação com a solução do problema da águas da cidade, principalmente com a drenagem das águas pluviais, e onde foram abordados diferentes conceitos para a implantação de soluções paisagísticas que pudessem acomodar novas funções de drenagem das águas, estabelecendo conexões com soluções tradicionais já implantadas. Dentre eles houve um plano de arborização do sistema viário do bairro e, em cima dele foi feito um estudo com a utilização do ENVI-met programa com um modelo tridimensional capaz de simular as interações entre superfícievegetação-atmosfera. Para isso foram utilizadosalguns cálculos da vegetação como: transpiração, evaporação, fluxo de calor sensível, fluxos turbulentos de calor e vapor; resistência dos estômatos, balanço energético da folha e balanço de água do sistema solo-vegetação. O objetivo era analisar, numa perspectiva de micro-escala, a interação entre o desenho urbano e o microclima. No intuito de se avaliar os benefícios da vegetação arbórea. Este programa é gratuito e está disponível em www.geographie.ruhr-unibochum.de/agklima/envimet 
- permitir recreação no sentido mais amplo da palavra, com grande gama de atividades,

- servir como caracterização de condições específicas de setores da cidade, além de funcionar como marcos visuais, etc,

- permitir a circulação de veículos e pedestres, com a preocupação de não limitar sua função à mera função de transporte. 


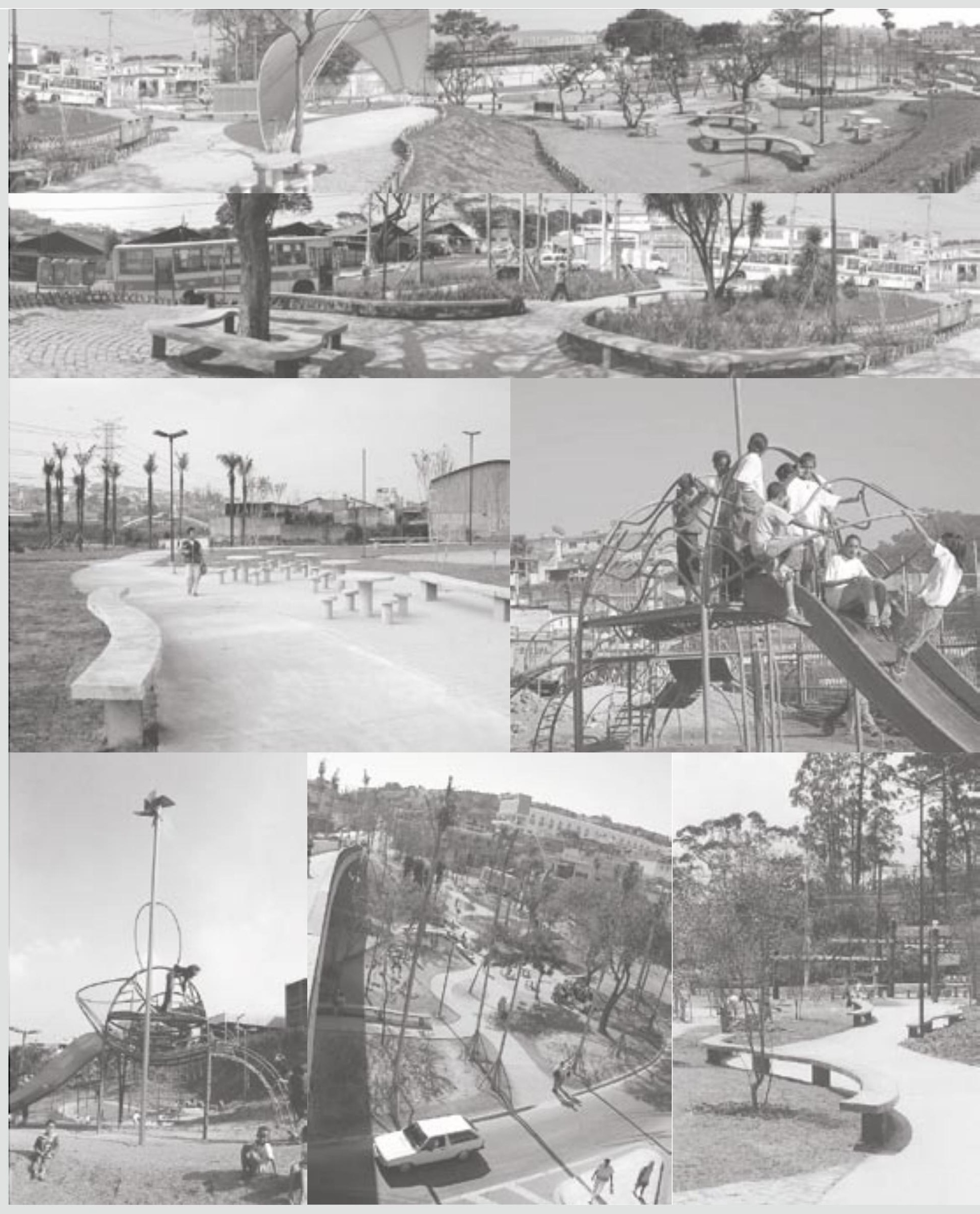




\section{C a pít ulo 06 CONSIDERAÇÕES FINAIS}

Esta pesquisa buscou compreender o processo de urbanização da cidade de São Paulo desde o início de sua colonização até a consolidação de sua periferia na segunda metade do século passado e quais foram as implicações desse crescimento na implantação de espaços de lazer e convívio na formação de um sistema de espaços livres.

Embora já ocorresse a utilização espontânea de áreas verdes naturais na periferia não urbanizada da cidade e nas várzeas dos rios como do Tamanduateí e do Carmo, a preocupação com a arborização e o ajardinamento dos espaços livres públicos se deu principalmente a partir da segunda metade do século XIX, com políticas públicas e planos para higienizar e civilizar a cidade, que duraram até o início de 1930.

Durante as primeiras décadas do século passado muitas ruas foram arborizadas e muitas praças ajardinadas, recuperouse o importante Jardim da Luz - que encontrava-se em abandono como verificamos nos primeiros capítulos - e implantou-se o primeiro grande parque público da cidade- o Parque Dom Pedro, que por sua dimensão e localização, talvez tenha sido a mais importante intervenção do poder público até a implantação do parque do Ibirapuera em 1954, uma vez que as demais intervenções estavam mais concentradas em regiões das cidade onde residia a população de alta renda como as imediações da Av. Paulista e o bairro de Higienópolis.

Nas décadas seguintes o que se implantou de espaços livres de convívio e lazer esteve relacionado principalmente à implantação do sistema viário. Houve portanto poucas políticas específicas para as áreas verdes visando a recreação pública, exceto pela administração na esfera do Departamento de Cultura 
e Recreação, com a criação e implantação dos Parques Infantis e dos Clubes de Menores, que possuíam uma programação que incluía atividades de lazer ao ar livre associadas à educação física e moral, mas infelizmente o programa também não teve apoio de gestões seguintes e foram poucas unidades implantadas, que depois acabaram-se perdendo ao longo dos anos.

Do ponto de vista de programas e projetos de parques e praças, em poucas ocasiões na história da cidade se investiu o suficiente neles e em geral, no município de São Paulo, o sistema de espaços livres de lazer e/ou conservação não é alvo de planos específicos, como costuma ser o caso das redes de infra-estrutura ou mesmo da rede viária.

O rápido processo de urbanização se deu sem planos gerais que orientassem as conexões e interrelações entre os núcleos urbanos que se configuravam com o crescimento populacional, assim como a consequente constituição de seu sistema de espaços livres públicos e privados.

Desse modo, os espaços livres públicos existentes resultaram, em parte significativa dos casos, da somatória de áreas livres públicas reservadas pelas glebas parceladas a ocupadas de formas diversas e em momentos históricos distintos; derivando de projetos de parcelamento de solo que, muitas vezes, ignoravam os instrumentos legais e os mecanismos institucionalizados de parcelamento e ocupação do solo urbano.

A existência de áreas parceladas irregularmente gerou um sistema de espaços livres de lazer e/ou conservação onde se observa a carência de praças e parques; mas que apesar de não respeitarem a legislação vigente, seguem na maioria dos casos a lógica de parcelamento das áreas em situação legal, só que esquivam-se das restrições referentes às dimensões mínimas de vias, lotes e reservas de áreas públicas.

Esse fato acentua o déficit de espaços livres quanto a aspectos distributivos e quantitativos, pois não existem áreas 
destinadas à implantação de equipamentos comunitários, praças ou parques e as vias de circulação apresentam dimensões mínimas possíveis, quase sempre inferiores às exigências legais.

Algumas áreas da cidade contam com maior número de áreas parceladas de forma clandestina ou irregular que outras, como por exemplo os setores urbanos localizados nos extremos sul - onde se localizam $33 \%$ do total de áreas irregulares, principalmente nas imediações das represas; e leste - com outras 39\%; aumentando ainda mias o déficit de espaços livres públicos, justamente em áreas mais carentes do município,

Nas áreas onde ocorreram ocupações clandestinas do território, a situação é gravada ainda mais pelo reduzido estoque de áreas públicas e pela utilização dessas poucas áreas existentes para outros fins como ocupação por favelas e implantação de equipamentos comunitários. Também são essas áreas as que tiveram maior redução do já limitado estoque de espaços livres em função da maior necessidade de equipamentos comunitários como creches e escolas.

A ocupação de áreas livres públicas destinadas a lazer e convívio também decorre da ausência de ação real do poder público no processo de configuração e qualificação da quase totalidade dos espaços livres públicos, uma vez que favelas e equipamentos ocupam as áreas doadas durante os processos legais de parcelamento do solo. Este estoque não foi tratado e equipado para configurar um sistema de espaços livres públicos de lazer ou conservação, facilitando a apropriação de outros usos.

Como o processo de ocupação da cidade de São Paulo ocorreu de forma pouco ou nada planejada e, que a maior parte da área urbana já está ocupada, contando com apenas 17,3\% de terrenos vagos na área urbanizada, segundo a Secretaria municipal de Planejamento, existe a real dificuldade na criação de áreas livres públicas urbanas de porte diferenciado e distribuição 
equitativa pela área urbanizada da cidade. E no caso de São Paulo a questão de distribuição de espaços livres públicos assume maior importância, pois as distâncias e dificuldades de locomoção são significativamente maiores.

Deste modo, o processo de ocupação do espaço urbano resultou num conjunto de áreas livres públicas urbanas onde a ausência de ações e procedimentos sistêmicos tem sido um impedimento para sua real adequação em relação às necessidades e demandas existentes. Agravando ainda mais essa situação, o descaso por parte dos governantes e habitantes em relação à produção e manutenção dos espaços livres públicos, refletiu na falta de políticas e instrumentos efetivos para ampliar o sistemas de espaços livres públicos e qualificar o já existente.

Assim, o conjunto de espaços livres, públicos ou privados, existentes num setor urbano, bairro ou cidade configura sempre um sistema - formal ou informalmente configurados, mas faz-se necessário a existência de um plano ou projeto urbano onde o conjunto de espaços livres seja considerado sistematicamente, levando à qualificação do sistema desde o momento de criação do desenho, constituindo-se como fator indutor de qualidade ambiental urbana, atrelado à gestão urbana integrada e continuada dos espaços gerados.

Além disso deveriam contar com estrutura e instrumentos eficazes que orientassem a produção coletiva da paisagem e a consequente configuração dos espaços livres. A falta dessa estrutura gerou a situação de crise descrita e consequentemente, um conjunto de áreas fragmentadas, distribuídas irregularmente pela área urbanizada do município e em número insuficiente para atendimento da demandas existentes.

Entre outros aspectos podemos dizer que a inadequação do sistema de espaços livres ocorreu devido à cidade ter se conformado e transformado por meio de intervenções isoladas onde há dificuldade de articulação entre os diferentes órgãos públicos que legislam na conformação do tecido urbano 
nas suas diferentes escalas de intervenção; há ausência de interesse do poder público e do setor privado na configuração e qualificação dos espaços livres públicos. Os parcelamentos de glebas poucas vezes estão atrelados a planos específicos de uso e ocupação do solo, o que dificulta a definição da densidade e controle da configuração da paisagem nos diferentes setores urbanos. Além disso, a quantidade insuficiente de áreas livres públicas decorre principalmente do grande número de operações irregulares de parcelamento do solo urbano, onde o poder público participa dessa situação por meio de uma série de falhas nos procedimentos administrativos; a insuficiência desses espaços é agravada pela sua distribuição irregular e atinge principalmente setores onde a ocupação clandestina foi mais intensa; muitos dos espaços livres públicos tiveram sua destinação desvirtuada - contando com isso com a participação do poder público e de iniciativas privadas. Assim o sistema de espaços livres públicos assume uma configuração marcada por deficiências na distribuição, adequação e na hierarquia de suas áreas, onde os espaços livres urbanos são quase sempre tratados como elementos quantitativos gerais e os aspectos de dimensões de cada espaço e distribuição são deixados em segundo plano.

Assim, o sistema de espaços livres da cidade de São Paulo continua sendo fruto do acaso e da somatória das ações dos empreendedores. A melhor a qualificação do sistema de espaços livres paulistanos só será possível a partir do momento que a qualificação desses espaços fizer parte do rol de prioridade da maior parte da população.

Diante do quadro do sistema de espaços públicos da cidade de São Paulo, ou melhor, da inexistência de um plano geral, sistematicamente estruturado, que permitisse a configuração de um sistema de espaços livres públicos destinados à circulação, à conservação ambiental, ao convívio e ao lazer urbanos, passível de atender as demandas que se consolidaram com a 
urbanização e o adensamento populacional, principalmente nas periferias da cidade; a maior contribuição do Programa Centros de Bairro ao sistema de espaços livres e à cidade foi a mudança do olhar para a cidade, onde o projeto paisagístico não foi visto apenas como um tratamento estético embelezador da cidade, mas como um componente de construção do meio ambiente urbano, capaz de transformar áreas e criar lugares de expressão da cidadania, com espaços livres públicos democráticos e qualificados, possibilitando a interação e o convívio social entre a comunidade, tornando-se rico elemento para a apropriação pública na esfera do cotidiano. 
6. Considerações Finais 


\section{REFER Ê NC|AS B | B L | O G R ÁF | C A S}

ALEX, Sun. Convívio e exclusão no espaço público: questões de projeto da praça. São Paulo. Tese de doutorado - Faculdade de Arquitetura e Urbanismo, Universidade de São Paulo, 2004.

ARANTES NETO, Antonio Augusto. Paisagens paulistanas: transformações do espaço público. Campinas: Editora da Unicamp, 2000.

ARANTES NETO, Antonio Augusto. Cultura Popular. Campinas: Editora da Unicamp, 2000.

ARANTES NETO, Antonio Augusto (org). O espaço da diferença. Campinas: Papirus, 2000.

ARENDT, Hannah. A condição humana. Rio de Janeiro: Forense Universitária, 1991.

BARTALINI, Vladimir. Parques municipais de São Paulo. São Paulo. Tese de doutorado - Faculdade de Arquitetura e Urbanismo, Universidade de São Paulo, 1999.

BESSE, Jean Marc. Von la Terre: six essays sue le paysage et la geográphie. Arles: Actes Sud/ENSP/Centre du paisaje, 2000.

BONDUKI, Nabil e ROLNIK, Raquel. Periferias, ocupação do espaço e reprodução de força de trabalho. São Paulo. Cadernos de seudos e pesquisa da FAUUSP, 1979.

BRUNO, Ernani Silva. Memória da cidade de São Paulo - depoimentos de moradores e visitantes. São Paulo. Registros 4. PMSP. 1981.

CAMPOS FILHO, Candido Malta. Cidades brasileiras: seu controle ou o caos. São Paulo. Studio Nobel, 1999.

CAMPOS FILHO, Candido Malta. Reinvente seu bairro: caminhos para você participar do planejamento da sua cidade. São Paulo. Ed. 34, 2003.

CERTAU, Michel de. A invenção do cotidiano: artes de fazer. Petrópolis: Vozes, 1994. 
CHOAY, Françoise. O urbanismo. São Paulo, Perspectiva, 1997.

Coleção Mosaico: ensaios e documentos. "Um Século de Luz", SP: Ed, Scipione, 2001.

COURBUSIER, Le. A carta de Atenas. São Paulo, edusp, 1993.

COURBUSIER, Le. Urbanismo. São Paulo, Martins Fontes, 1992.

CULLEM, Gordon. “Paisagem Urbana”, Lisboa: Edições 70,1993.

DI MARCO, Anita Regina e ZEIN, Ruth Verde. "Sala São Paulo de Concertos", SP: Alter Market, 2001.

DOURADO, Guilherme Mazza. Visões de Paisagem. São Paulo, ABAP, 1997.

EMPLASA - Arquivo do Estado. Memória Urbana: a grande São Paulo até 1940. São Paulo, Imprensa Oficial, 2001.

ESTATUTO DA CIDADE. Guia para implementação pelos municípios e cidadãos. Brasilia, 2001.

FAGGIN, Maria Ângela. As Tramas da segregação: privatização do espaço público. Tese e livre docência, Faculdade de Arquitetura e Urbanismo, Universidade de São Paulo, 1998.

FAGGIN, Maria Ângela. Natureza e cultura: paisagens, objetos e imagens. In Revista Paisagem e Ambiente: ensaios n. 18. São Paulo, Universidade de São Paulo, 2005.

FAGGIN, Maria Ângela. A produção e o uso da paisagem metropolitana. Texto de aula - Faculdade de Arquitetura e Urbanismo da Universidade de São Paulo.

FERRARA, Lucrecia. Os significados urbanos. São Paulo: Edusp, 2000.

HELLER, Agnes. O cotidiano e a história. São Paulo: Paz e Terra, 1992.

HOUGH, Michael. Naturaleza e ciudad. Barcelona. Gustavo Gili, 1995.

IPLANRIO. Rio Cidade: o urbanismo e volta às ruas, RJ: Mauad, 1996.

IPLANRIO.Corredor Cultural. Rio de Janeiro: Prefeitura do Rio de Janeiro, 1985.

JACOBS, Jane. Morte e vida das grandes cidades. São Paulo. Ed. Martins 
Fontes, 2000.

JELLICOE, Susan and Geoffrey. El paisage del hombre. Barcelona, Gustavo Gili, 1995.

JAMESON, Frederic. Pós-modernismo, a lógica cultural do capitalismo tardio. São Paulo: Ática, 1996.

KLIASS, Rosa Grena. Parques urbanos de São Paulo. São Paulo. Ed. Pini, 1993.

LAURIE, Michael. Intodución a la Arquitectura del Paisaje. Barcelona: GG, 1983.

LIMA, Catharina Pinheiro Cordeiro dos Santos. A Natureza na Cidade, A natureza da Cidade. São Paulo, tese de doutorado, FAUUSP, 1996.

MACEDO, Silvio S. Quadro do Paisagismo no Brasil. São Paulo: Edusp, 1999.

MACEDO, Silvio S. \& ROBBA, Fabio. Praças Brasileiras. São Paulo: Edusp , 2002.

MACEDO, Silvio S. \& SAKATA, Francine G. Parques Urbanos no Brasil. São Paulo: Edusp, 2002.

MCHARG, Ian L. Proyectar con la naturaleza. Barcelona, Gustavo Gili, 2000.

MAGNOLI, Miranda M. Espaços Livres e Urbanização: uma Introdução a Aspectos da Paisagem Metropolitana. São Paulo, Tese de livre docência, FAUUSP, 1983.

MENNEH, Marcia Halluli. O Sistema de Espaços Livres Públicos da Cidade de São Paulo. Tese de doutorado. FAUUSP. São Paulo, 2002.

MEYER, Regina Maria Prosperi. São Paulo Metrópole. São Paulo, Edusp, 2004.

NAMIQUE, Fábio. Manutenção de praças na cidade de São Paulo. Estudo de caso: brinquedos do programa Centros de Bairro. São Paulo. Dissertação de mestrado - Instituto de Pesquisas Tecnológicas o Estado de São Paulo, 2005.

NIEMEYER, Carlos Augusto da Costa. A criação de espaços públicos de lazer organizado como expressão de cidadania: o caso dos parques infantis em 
São Paulo (1934-1954). São Paulo. Dissertação de mestrado - Faculdade de Arquitetura e Urbanismo, Universidade de São Paulo, 2001.

OLIVEIRA, Sueli Aparecida Bissoli de. Os espaços públicos nos bairros periféricos da cidade de São Paulo: o caso da zona leste. São Paulo. Dissertação de mestrado - Faculdade de Arquitetura e Urbanismo, Universidade de São Paulo, 2003.

Os Sistemas de Espaços Livres e a Constituição da Esfera Pública Contemporânea no Brasil. - Pesquisa temática nacional. SEL/QUAPA. Faculdade de Arquitetura e Urbanismo, Universidade de São Paulo, 2006.

PEREIRA, Raul Isidoro. O sentido da paisagem e a paisagem consentida: projetos participativos na produção do espaço livre público. São Paulo. Tese de doutorado - Faculdade de Arquitetura e Urbanismo, Universidade de São Paulo, 2006.

QUEIROGA, Eugenio. A metrópole e a praça: o espaço entre a razão de dominação e a ação comunicativa. São Paulo. Tese de doutorado - Faculdade de Arquitetura e Urbanismo, Universidade de São Paulo, 2001.

QUEIROGA, Eugenio. Praças e pracialidades em design: da visualidade da paisagem à visibilidade dos lugares. Artigo apresentado na disciplina AUP5834 da Faculdade de Arquitetura e Urbanismo, Universidade de São Paulo, 2005.

ROBBA, Fabio. A praça contemporânea nas capitais brasileiras. São Paulo. Tese de doutorado - Faculdade de Arquitetura e Urbanismo, Universidade de São Paulo, 2005.

RUANO, Miguel. Ecourbanismo: entornos humanos sostenibles. Barcelona, Gustavo Gili, 1999.

SABER, Azis Ab'. São Paulo: Ensaios Entreveios. São Paulo, Edusp, 2004.

SALDANHA, Nelson. O jardim e a Praça. São Paulo, Edusp, 1993.

SAKATA, Francine G. O projeto paisagístico como instrumento de requalificação urbana. São Paulo. Dissertação de mestrado - Faculdade de Arquitetura e Urbanismo, Universidade de São Paulo, 2004.

SANTOS, Milton. A natureza do espaço: técnica e tempo, razão e emoção. 
São Paulo: Edusp, 2004.

SANTOS, Milton. O Espaço do Cidadão. São Paulo: Nobel, 1987.

SANTOS, Milton. Metamorfoses do espaço habitado. São Paulo: Hucitec, 1988.

SEGAWA, Hugo. Ao Amor do Público: Jardins no Brasil. São Paulo: Nobel, 1996.

SILVEIRA, Lauro Frederico Barbosa da. Planejamento Urbano e soberania civil. In: SOUZA, M.A.; LINS, S.C., SANTOS, M.P.C.; SANTOS, M.C. Metrópole e globalização. São Paulo: CEDESP, 1999.

SPIRN, Anne Whiston. O Jardim de Granito: a natureza do desenho da cidade. São Paulo: Edusp,1995.

TOLEDO, Benedito Lima de. São Paulo: três cidades em um século. São Paulo, Duas Cidades, 1983.

VIGNOLA JÚNIOR, Roberto. A arborização das vias públicas e a paisagem urbana: caso da cidade de São Paulo. São Paulo. Dissertação de mestrado - Faculdade de Arquitetura e Urbanismo, Universidade de São Paulo, 2005.

\section{Outras fontes}

Entrevista realizada em NOV/2005 com o arquiteto coordenador do Programa Centros de Bairro - Arq $^{\circ}$ Sérgio Marin de Oliveira.

Entrevista realizada em NOV/2005 com o arquiteto responsável pelas praças da Capela do Socorro do programa Centros de Bairro - Arqt $^{\circ}$ Daniel Larrabure Meirelles. 
